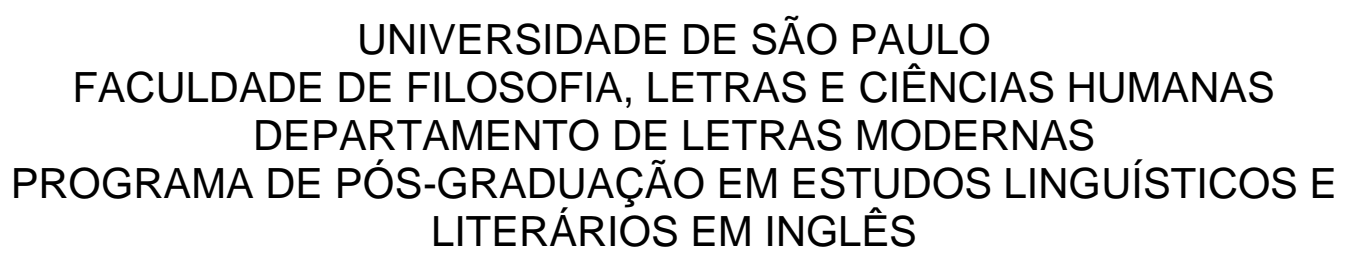

ANTONIO MARCOS ALEIXO

Um épico possível: refuncionalizações de técnicas, formas e clichês, em Nashville, de Robert Altman 
UNIVERSIDADE DE SÃO PAULO

FACULDADE DE FILOSOFIA, LETRAS E CIÊNCIAS HUMANAS

DEPARTAMENTO DE LETRAS MODERNAS

PROGRAMA DE PÓS-GRADUAĈ̃O EM ESTUDOS LINGUÍSTICOS E

LITERÁRIOS EM INGLÊS

ANTONIO MARCOS ALEIXO

\title{
Um épico possível: refuncionalizações de técnicas, formas e clichês, em Nashville, de Robert Altman
}

\author{
Tese apresentada ao Programa de Pós-graduação em \\ Estudos Linguísticos e Literários em Inglês, do \\ Departamento de Letras Modernas, da Faculdade de \\ Filosofia, Letras e Ciências Humanas, da Universidade de \\ São Paulo, para a obtenção do título de Doutor em Letras.
}

Área de concentração: Estudos de Cultura - relações entre literatura e cinema contemporâneo nos EUA

Orientador: Prof. Dr. Marcos César de Paula Soares

São Paulo

2013 
Nome: ALEIXO, Antonio Marcos

Título: Um épico possível: refuncionalizações de técnicas, formas e clichês, em Nashville, de Robert Altman

Tese apresentada ao Programa de Pós-graduação em Estudos Linguísticos e Literários em Inglês, do Departamento de Letras Modernas, da Faculdade de Filosofia, Letras e Ciências Humanas, da Universidade de São Paulo, para a obtenção do título de Doutor em Letras.

Aprovado em:

Banca Examinadora

Prof. Dr.: Instituição:

Julgamento: Assinatura:

Prof. Dr.: Instituição:

Julgamento: Assinatura:

Prof. Dr.: Instituição:

Julgamento: Assinatura:

Prof. Dr.: Instituição:

Julgamento: Assinatura: 


\section{Agradecimentos}

À Coordenação de Aperfeiçoamento de Pessoal de Nível Superior (CAPES), pela bolsa concedida.

À Profa. Doutora Maria Elisa Burgos Pereira da Silva Cevasco e ao Prof. Dr. Sérgio de Carvalho, pela leitura atenta e pelas sugestões no exame de qualificação.

Ao Prof. Dr. Marcos César de Paula Soares, pela orientação amistosa, mas sempre exigente.

Ao amigo Flávio, interlocutor constante.

Aos meus pais e aos meus irmãos. 


\section{Resumo}

Lançado em 1975, Nashville é uma das últimas produções de um período da cinematografia norte-americana conhecido como "Nova Hollywood" ou "Renascença Hollywoodiana". Tomando a "capital da música country" nos EUA como objeto de crítica e pano de fundo espacial da narrativa, o filme reflete sobre problemas políticos e sociais de seu tempo. A tese que orienta o presente trabalho é a de que a "imagem da História" evocada em sua narração só foi possível porque o diretor e seus colaboradores fizeram um esforço consciente para apropriar-se do repertório fílmico industrial de técnicas, formas e até mesmo clichês, "refuncionalizando-o" de modo a torná-lo adequado à expressão de sua visão crítica. O resultado é, ao mesmo tempo, um "retrato dialético" dos EUA no início dos anos 1970, uma prova da possibilidade da encenação épica no contexto industrial e um exemplo de resistência cultural a partir da organização produtiva dos trabalhadores do cinema.

Palavras-chave: Estudos de Cultura, literatura e cinema, Robert Altman, Sociedade do Espetáculo, narração épico-dialética. 


\section{Abstract}

Launched in 1975, Nashville is one of the last productions of a period in American cinema known as "the New Hollywood" or "Hollywood Renaissance". Taking the "capital of country music" in the USA as the object of criticism and spatial backdrop of its narrative, the film reflects upon social and political problems of its time. The thesis that guides the present study is that the "image of history" evoked by its narration was possible only because the director and his collaborators made a conscious effort to apropriate the repertoire of industrial filmic techniques, forms and even clichés, "refunctioning" it to make it suitable to the expression of their critical point of view. The result is, all at the same time, a "dialectical picture" of the USA at the beginning of the 1970s, concrete evidence of the possibility of "epic mise-en-scène" in the industrial context and an example of cultural resistance built upon the productive organization of cinema workers.

Keywords: Cultural Studies, literature and cinema, Robert Altman, Society of the Spectacle, epic-dialectical narration. 


\section{Sumário}

1: para começar, um comercial............................................................... p. 8

2: country music é política.................................................................... p. 27

3: uma sociedade sitiada pelo espetáculo................................................. p. 64

4: o funcionamento da máquina.......................................................... p. 128

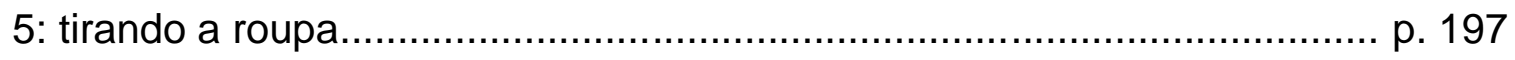

6: para terminar, um assassinato........................................................ p. 273

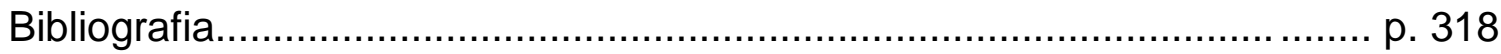




\section{1: para começar, um comercial}

Silêncio. Tela escura. Logotipo dos estúdios Paramount em preto e branco. Abaixo, créditos dos proprietários dos estúdios desde 1966: "A Gulf + Western Company®". Fade-out. Tela escura. No centro do quadro, surgem, em fade-in, os créditos da distribuidora - "ABC ENTERTAINMENT apresenta" - reproduzidos, em baixo contraste, em uma espécie de "fantasma" da imagem original, no canto inferior esquerdo da tela. $O$ mesmo acontece com os créditos do produtor e do diretor: "uma produção de JERRY WEINTRAUB", "um filme de ROBERT ALTMAN." Fade-out.

Simultaneamente, a tela escura e a trilha sonora vazia são invadidas pela profusão de imagens e sons de um comercial de televisão. No centro da tela, surge um objeto que gira na direção do primeiro plano, aí se fixando; trata-se da capa de uma trilha sonora intitulada "Nashville", sobre a qual se exibe uma pintura representando vinte e quatro personagens. Atrás dessa imagem, giram, em sentido horário, as capas de discos de cinco artistas country fictícios: Connie White, Barbara Jean, Haven Hamilton, o trio Bill, Mary \& Tom e Tommy Brown. Do lado esquerdo da tela, é exibida, em movimento ascendente, uma lista com os nomes de vinte e quatro atores relativamente desconhecidos, precedida da clássica introdução: "estrelando". Do lado direito, em movimento descendente, são exibidos os títulos de uma série de canções, todas desconhecidas.

Sobre um fundo musical composto por um pot-pourri das canções identificadas nos créditos, surge um locutor, no estilo de antigos anúncios radiofônicos, fazendo o comercial de um filme:

"Agora, depois de anos em produção, Robert Altman traz para a tela grande o tão esperado Nashville, com vinte e quatro, pode contar!, vinte e quatro de seus stars favoritos! David Arkin, Barbara Baxley, Ned Beatty, em Nashville! E as performances 
fabulosas de Karen Black, Ronee Blakley, Timothy Brown, em Nashville!, junto com os espetaculares Keith Carradine, Geraldine Chaplin, com Robert Doqui, em Nashville! E as participações excitantes de Shelley Duvall, Allen Garfield e Henry Gibson, em Nashville! E os fantásticos Scott Glenn, Jeff Goldblum, Barbara Harris, em Nashville! Isso sem falar nos sensacionais David Hayward, Michael Murphy, Allan Nicholls, em Nashville! E os maiores de todos os tempos, Dave Peel, Cristina Raines, Bert Remsen, em Nashville! E mais os incríveis Lily Tomlin, Gwen Welles e Keenan Wynn, em Nashville!"

Enquanto o locutor lista os "stars" de Nashville, o enquadramento formado pela capa de disco no centro da imagem se transforma em uma "tela" dentro da tela de cinema; aproximando-se em zoom-in da representação do rosto de David Arkin no meio da pintura, esta "tela" exibe, em uma série de close-ups, imagens dos outros vinte e três atores, em sincronia com a fala do locutor. Ao mesmo tempo, cada vez que ele diz "em Nashville!", o título do filme é reiterado na tela, em letras garrafais, em cores e fontes variadas. Terminada a exposição individual dos rostos, a pintura coletiva é novamente distanciada em zoom-out; as imagens que giravam em sentido horário desaparecem junto com os créditos; a capa da trilha sonora inverte seu movimento inicial, girando na direção do segundo plano até desaparecer, em fade-out. Na tela escura, fica apenas o título do filme, "piscando" em letras brancas. O volume do pot-pourri vai diminuindo até que o único som restante é a voz do locutor que, como se temesse não conseguir "dar seu recado" antes do fim do comercial, acelera o ritmo da fala, atropelando as últimas palavras:

"Seja o primeiro no seu bairro a se maravilhar com estes stars magníficos, por meio da magia do som estereofônico e da imagem em cores vivas, bem diante dos seus olhos, sem interrupções comerciais!"

Estes são os primeiros enunciados de Nashville, de Robert Altman, produzido e filmado entre 1973 e 1974, e lançado em 1975. Não são exatamente enunciados narrativos, pois, em vez de começar a tecer uma ficção, eles apenas nos oferecem a história que ainda não começamos a ver. 
Neste sentido, são, essencialmente, enunciados retóricos; falam diretamente ao público de modo a estabelecer as condições de recepção do relato: a obra é oferecida como mercadoria e o espectador é distanciado pelo tratamento como consumidor de novidades tecnológicas ("seja o primeiro no seu bairro a se maravilhar..."). Evidentemente, não se trata de publicidade, pois não estamos diante de um comercial e sim da sequência de abertura de um filme; a forma de comercial aqui é tão-somente uma estratégia retórica adotada para o estabelecimento do "contrato de leitura" peculiar à narrativa "autorreferencial", que, dado o quadro enunciativo em que é produzida, precisa abrir mão da verossimilhança.

"Pode-se afirmar que a autorreferência é [...] algo como uma conotação suplementar por meio da qual a obra tenta justificar sua própria existência e documentar a própria situação histórica em que a autorreferencialidade emerge: a fragmentação do público, a crise dos gêneros, a perda de status da arte no mercado."1

Que a obra precise "justificar sua existência" é evidência do contexto artisticamente hostil em que ela emerge; que ela o faça expondo a forma degradada que este contexto lhe impõe é sinal de seu ímpeto crítico, inclusive contra si própria. Em outro contexto, Sartre discorre sobre o "tom agressivo" que a arte é obrigada a tomar nos momentos históricos em que artista e público são transformados em adversários econômicos e políticos:

"A partir de 1848, de fato, e até a guerra de 1914, a unificação radical de seu público leva o escritor a escrever, por princípio, contra todos os seus leitores. Se por um lado ele vende suas produções, por outro ele despreza aqueles que as compram e se esforça para evitar a satisfação de seus desejos [...]. E se porventura o livro que se publica não fere o bastante, ajunta-se aí um prefácio escrito para insultar."”

Nashville é produzido em um desses momentos em que 0 artista não pode pressupor uma aliança com seu público; a sequência de abertura em forma de comercial é, por assim dizer, o "prefácio do autor" anteposto aos enunciados narrativos, por meio do qual o espectador é lembrado

\footnotetext{
${ }^{1}$ JAMESON, Fredric. Brecht and Method. p. 89.
} 
de suas implicações no processo que o transformou em consumidor e a obra em mercadoria. Não é casual que Peter Lev, por exemplo, inclua Nashville em uma linhagem de filmes que marcam o "fim das utopias" dos anos 1960, apresentando "os fracassos da imaginação na música, na política e na vida pessoal." ${ }^{3}$

De fato, o começo dos anos 1970 nos EUA oferece a imagem de uma derrota generalizada da imaginação radical: no campo político, assistia-se à construção de uma hegemonia de direita, após uma década de conflitos e ações violentas; no econômico, a equipe de Nixon dava o pontapé inicial no desmanche das estruturas que haviam sustentado décadas de produção "fordista", preparando o país para a nova realidade do capitalismo global que se anunciava; no que tange a cultura, e, mais especificamente, a produção cinematográfica, 1975, ano de lançamento de Nashville, marcou o fim da chamada "Renascença Hollywoodiana" e, com ela, a interrupção de uma cadeia de filmes artisticamente ambiciosos dentro do aparato industrial.

"Com o lançamento de Nashville e Tubarão, o verão de 1975 apresentou tanto o ápice quanto o começo do fim daquele período. Nashville parecia encarnar as esperanças do crítico de arte para o futuro do cinema americano. Aqui estava um artista pondo a maquinaria da cultura popular a serviço da arte, ao mesmo tempo em que entrava no espírito da cultura popular, inclusive partilhando de sua energia. Aquilo tudo era um sonho: a força da cultura de massas combinada com a complexidade da arte, o alto e o baixo não mais em conflito, nem tampouco absorvidos um no outro, mas apenas se abraçando. [...]. Porém, foi Tubarão que capturou o público de massas e realmente modificou o cinema norte-americano."

Entre fins dos anos 1960 e o ano de 1975, Hollywood passara por profundas transformações econômicas e culturais. De um lado, os cinco maiores estúdios (Paramount, Warner Bros., MGM, Twentieth Century Fox e Columbia) haviam sofrido perdas vultosas com projetos grandiosos; do outro,

\footnotetext{
${ }^{2}$ SARTRE, Jean-Paul. Qu'est-ce que la littérature? p. 124 - 125.

${ }^{3}$ LEV, Peter. The End of the Sixties. in: American Films of the 70s: conflicting visions. p. 62.

4 SAWHILL, Ray. A movie called "Nashville". Salon.com (versão online). Ver também: HOBERMAN, Jian. "Nashville contra Jaws or 'The imagination of Disaster' revisited". In:
} 
filmes endereçados ao recém-descoberto "mercado jovem", utilizando uma estética modernosa, normalmente copiada do cinema "autoral" europeu, provaram ser extremamente populares junto à geração "baby-boom", "ávida por mídias que espelhassem a sua condição desprivilegiada." ${ }^{5}$ No meio desse processo, alguns estúdios foram comprados por grandes conglomerados, caso da Paramount, adquirida pelo grupo industrial Gulf \& Western, em 1966, e da United Artists, absorvida pela empresa de seguros Transamerica Inc., ou se juntaram com estúdios menores, formando conglomerados de mídia, caso da empresa formada pela fusão da Warner Bros. com a Seven Arts Production, uma distribuidora de filmes para televisão. Enquanto buscavam um novo modelo de produção que recuperasse as perdas econômicas sofridas na primeira metade da década, os estúdios e os novos conglomerados de mídia investiam em produções pequenas ou independentes, atuando primordialmente como distribuidores.

Com a diminuição dos custos de produção, tornou-se viável oferecer uma relativa liberdade criativa aos jovens diretores empregados nestes filmes. Chamados de "Hollywood brats" e de "film generation", diretores como Sam Peckinpah, Peter Bogdanovich, Arthur Penn, dentre outros, aproveitaram a chance recebida para modernizar a cinematografia norteamericana, trazendo para Hollywood temas "quentes" como a contracultura e a violência política do período. Tal foi o "respiro" que seus filmes trouxeram ao "mofado" cinema clássico que esta geração foi imediatamente chamada de "Nova Hollywood" ou "Renascença Hollywoodiana", muito embora avaliações posteriores tenham sugerido que seu trabalho contribuiu mais para o reforço do aparato comercial hollywoodiano do que para a criação de uma cinematografia radical nos Estados Unidos.

Ainda que pertencesse a uma geração anterior aos "Hollywood brats", Altman se aproveitou do período de relativa liberdade entre o 
começo da década e 1975 para produzir seus filmes mais ousados. Com o prestígio alcançado com M.A.S.H. (idem, 1970), um sucesso de bilheteria que nunca mais conseguiria repetir, o diretor criou condições para produzir, em sequência, Voar é Com os Pássaros (Brewster McCloud, 1970), Onde os Homens são Homens (McCabe \& Mrs. Miller, 1971), Imagens (Images, 1972), O Perigoso Adeus (The Long Goodbye, 1973), Renegados até a Última Rajada (Thieves Like Us, 1974) e Jogando Com a Sorte (California Split, 1974). Neste período, a cinematografia de Altman se enriqueceu com uma experimentação consistente e contínua; destacam-se seu trabalho com uma equipe de atores e técnicos mais ou menos fixa, a utilização de diálogos improvisados e a resultante fragmentação do roteiro em narrativas incompletas que se entrecruzam, a utilização expressiva de movimentos panorâmicos, do zoom e do formato de tela Panavision, bem como o desenvolvimento de uma técnica de captação e mixagem de som que permitisse sobrepor vozes e ruídos sem a perda de nitidez. Na medida em que todos estes experimentos foram potencializados em Nashville, é possível encarar o filme como uma síntese do trabalho de Altman na primeira metade da década de 1970, embora as dificuldades encontradas para produzi-lo já indicassem que ele seria, provavelmente, o último "rebento" da "Renascença Hollywoodiana."

Desde que $O$ Perigoso Adeus fracassara comercialmente, Altman vinha tendo dificuldades financeiras, junto à United Artists, para concluir seu filme seguinte: Renegados até a Última Rajada. De olho no sucesso comercial da música country naqueles anos 1970 e objetivando alavancar a carreira do cantor Tom Jones, uma estrela do braço fonográfico da United Artists, os executivos do estúdio se dispuseram a financiar a conclusão de Renegados até a Última Rajada, desde que Altman concordasse em dirigir

\footnotetext{
${ }^{5}$ WYATT, Justin. High Concept: Movies and Marketing in Hollywood. p. 72.

${ }^{6}$ À época do lançamento de Nashville, o crítico do New York Times já alertava que, entre os produtores de Hollywood, a percepção mais comum era que "os projetos de Altman são controversos e às vezes sequer são lucrativos. As razões são óbvias: o diretor despreza convenções narrativas tradicionais, tais como enredo, exposição e motivação." GARDNER, Paul. Altman Surveys "Nashville" and Sees "Instant" America. New York Times, 13 de junho de 1975, p. 26.
} 
The Great Southern Amusement Company, um musical estrelado por cantores country. Resistente à ideia de filmar roteiros prontos sob encomenda, Altman aceitou a proposta, com a condição de enviar a jovem roteirista Joan Tewkesbury, com quem ele trabalhava naquele momento, a Nashville, a cidade da country music, onde ela deveria tomar notas e elaborar uma versão mais ao seu estilo, mas que agradasse também aos executivos da United Artists. Não agradou. Conta-se que a reação do chefe de produção, ao ler o novo roteiro, intitulado Nashville, foi taxativa: "isso não é um filme."”7

A partir desse ponto, o projeto de Nashville teve de seguir outro caminho: Altman apresentou o roteiro de Tewkesbury a Jerry Weintraub, um jovem produtor com fama de "excelente vendedor". Valendo-se do recente prestígio conquistado na divisão de entretenimento da $A B C$, Weintraub convenceu o canal de televisão a financiar o filme sobre a cidade do country. Porém, como a reputação de Altman estava manchada por seus recentes fracassos de bilheteria, uma solução de compromisso teve de ser encontrada: a $A B C$ não contrataria o diretor como um funcionário, mas 0 transformaria em uma espécie de coprodutor; em troca dos direitos de distribuição em meio televisivo, a $A B C$ Ihe repassava 2,2 milhões de dólares, junto com a responsabilidade de contratar elenco e equipe técnica, além do ônus de toda quantia que ultrapassasse o valor contratado.

Enquanto se "contavam moedas" para produzir Nashville, a indústria já dava indícios de que o modelo de produção representado por Altman e seus colaboradores não sobreviveria por muito tempo.

"Em 1970, o enorme sucesso popular de dois filmes convencionais, Love Story: uma história de amor (Love Story, Arthur Hiller) e Aeroporto (Airport, Geoge Seaton), restauraram a confiança de Hollywood no filme de grande orçamento e apelo de massas, e os anos 1970 testemunharam uma inflação nos custos de produção dos filmes americanos, sem paralelo na história da indústria. [...]. Para gerar lucros, esses investimentos

${ }^{7}$ apud STUART, Jan. The Nashville Chronicles. p. 40. 
inflacionados requeriam retornos estrondosos na bilheteria, de modo que os riscos financeiros da produção foram multiplicados substancialmente. Isto levou a uma tendência no sentido de uma diminuição dos filmes produzidos ano a ano, acompanhada por um crescimento constante dos valores gastos em publicidade e campanhas de marketing, cada vez mais planejadas de modo a garantir o sucesso dos projetos. Estes novos gastos com propaganda frequentemente alcançavam a soma de duas vezes o valor dos custos de produção."

Ao mesmo tempo em que Altman tentava juntar recursos para produzir Nashville, um jovem diretor de 26 anos de idade era contratado pela Universal para dirigir uma versão cinematográfica de Jaws, um romance cujos direitos de adaptação haviam sido comprados em 1973, um ano antes de sua publicação. Com um custo total de 9 milhões de dólares, Tubarão, o filme resultante desta adaptação, arrecadaria mais de 470 milhões e definiria 0 modelo de produção que os estúdios e os conglomerados passariam a perseguir a partir de 1975. Justin Wyatt, estudioso das relações entre marketing e estética em Hollywood resumiu, da seguinte forma, a história do filme high concept, o modelo lançado pelo Tubarão, de Spielberg:

"o filme high concept foi moldado pelo desenvolvimento de um novo sistema de distribuição e pelo aumento da concentração e da formação de conglomerados na indústria do cinema. O high concept, um produto audiovisual que tem como diferenciais o seu estilo e sua integração com o marketing e o mechandising, é uma resposta a mudanças estruturais na indústria. Centrados em imagens arrojadas e "marquetáveis", os filmes high concept são construídos de modo a atingir um público específico e a veicular uma imagem forte, capaz de carregar o produto através de várias janelas de lançamento. Deste modo, o high concept pode ser descrito como um tipo de filme no cinema norte-americano contemporâneo cujo estilo é marcado por motivações econômicas diretas. Tal estratégia econômica se liga a uma conceituação do mercado de cinema como um ambiente estilhaçado pela diferenciação de produtos e pela segmentação. Por meio de uma segmentação de mercado bem definida e das diferenças estéticas entre os filmes, alguns dos grandes estúdios, sobretudo a Paramount, criaram um espaço para o high concept na história do cinema."

Mais do que qualquer outra coisa, o high concept significou a integração do marketing ao processo de elaboração estética. Uma

${ }^{8}$ COOK, David. A History of Narrative Film. p. $933-934$. 
vez descoberto este modelo, os grandes estúdios cessariam de financiar projetos mais ousados e concentrariam seus investimentos em filmes construídos ao redor de um "gancho de marketing": um grande star, a adaptação de uma obra com sucesso já comprovado, um determinado efeito especial ou uma nova tecnologia de imagem ou de som, um argumento simples, etc. Para além do previsível empobrecimento estético dos filmes, o resultado sensível desta mudança foi a diminuição do número de trabalhadores técnicos e artísticos empregados na indústria.

"O fato de que em 1978 havia aproximadamente três mil diretores competindo para trabalhar em aproximadamente setenta grandes filmes fornece 0 índice das limitações que esta situação causou ao cinema americano contemporâneo." ${ }^{10}$

Embora Nashville tenha sido produzido exatamente durante a transição do sistema de estúdios para a nova realidade da produção orientada pelo high concept, a sequência de abertura do filme parece intuir o caminho que a cinematografia norte-americana estava tomando, reconhecendo, na forma de ironia autorreferencial, alguns cerceamentos à atividade criativa que só viriam a ficar mais definidos nos anos seguintes. Para começar, o filme começa com um comercial de si mesmo, respondendo, em tom de "gozação", à exigência de que o projeto high concept contenha sequências semiautônomas, de preferência clipes musicais, que possam ser facilmente extraídas para servir de spots televisivos. Além disso, o fato de que o comercial apresenta a trilha sonora de Nashville como um LP coletivo lembra a exigência de que a obra produzida pelos conglomerados se desdobre em mercadorias que possam circular por todas as "janelas de distribuição" do mesmo grupo de empresas: discos, vídeo clipes, brinquedos, publicações, alimentícios, etc. A ênfase nos aspectos técnicos do filme ("som estereofônico", "cores vivas") zombam da sedução que a maquinaria do cinema passava a representar para o público de filmes como Tubarão. Finalmente, a referência a Nashville como um grande espetáculo que, "depois de anos em produção", é oferecido ao consumidor pelo

\footnotetext{
${ }^{9}$ WYATT, Justin. High Concept: Movies and Marketing in Hollywood. p. 108.
} 
famoso Robert Altman, trazendo nada menos do que "vinte e quatro, pode contar!, vinte e quatro de seus stars favoritos!", toca em três exigências da nova estrutura produtiva da indústria: que o filme seja promovido como um "grande evento", normalmente por meio de publicidade intensiva e "saturation booking" (estreia em um grande número de salas de cinema); que a experiência de consumo prometida seja respaldada pela marca de um "American auteur"; que o risco do capital investido seja diminuído pela quantidade contratada de "star power" (termo utilizado no marketing para se referir ao valor econômico dos stars). Evidentemente, em Nashville, as três alusões têm função de autoescárnio: o filme estava longe de ser uma superprodução, o diretor vinha sendo associado a fracassos de bilheteria e o "star power" do elenco praticamente desconhecido era perto de "zero".

Essa crítica a um modelo de filme comercial que, naquele momento, ainda não estava consolidado, não é uma simples casualidade; de fato, por meio dela, Altman demonstra sua capacidade de "ler" as mudanças que estavam ocorrendo na sua atividade artística e profissional. A hipótese que orienta o presente trabalho é a de que o diretor não apenas estava consciente do avanço da forma mercadoria sobre a sua atividade, como entendeu que o fim da "Renascença Hollywoodiana" e a imposição do high concept se relacionavam com um desmanche muito mais amplo da produção cultural e da construção de um projeto democrático nos EUA. Uma evidência desse ímpeto de produzir uma crítica mais abrangente é o fato de que Nashville não é apenas um retrato da cultura country, mas também, e principalmente, "um filme sobre a América, sobre o espetáculo que ela representa para si mesma, sobre sua autorreflexão às vésperas de seu bicentenário." ${ }^{11}$

Um projeto tão ambicioso impunha desafios consideráveis ao diretor. Como produzir, de dentro da indústria cultural, uma crítica dos processos de desmonte da produção artística quando os meios

\footnotetext{
${ }^{10}$ COOK, David. A History of Narrative Film. p. 935.

${ }^{11}$ BOURGET, Jean-Loup. Robert Altman. p. 9
} 
necessários à sua realização compunham o próprio aparato industrial que se reestruturava? A segunda hipótese que orienta o presente trabalho é que o diretor, talvez pressentindo que o seu modo de trabalhar logo se tornaria inviável em Hollywood, tratou de se apropriar dos meios técnicos existentes e de colocálos a serviço do projeto de Nashville. Entretanto, alguns desses meios tiveram de ser refuncionalizados, outros foram apropriados criticamente (por exemplo, o uso irônico da técnica de montagem em campo e contracampo) e, frequentemente, Altman teve de desenvolver, junto com sua equipe técnica, instrumentos que a indústria do cinema não oferecia, tais como aparelhos capazes de captar, simultaneamente, múltiplas fontes sonoras.

Além do desafio do acesso aos meios de produção necessários à sua visão crítica, Altman deparou ainda com uma dificuldade artística: como representar processos que ainda não se concluíram e cujas causas e repercussões não podem ser intuídas com absoluta clareza? Por exemplo, um dos temas de fundo de Nashville é o caso Watergate; mas a renúncia de Nixon, um primeiro fechamento do processo, ocorreu quando as filmagens já estavam em andamento. Que forma de representação poderia permitir que os processos contraditórios da História fossem captados no dia a dia da produção, filmagem e montagem do filme? Seguramente, a narrativa tradicional, com sua rígida linha de desenvolvimento, descrevendo uma "curva dramática", que apenas desdobra um final contido, in nuce, na apresentação, não poderia acolher adições de última hora nem representar processos contraditórios, não lineares. O mesmo vale para o esquema de trabalho industrial; o sistema hollywoodiano, que faz do set um lugar aonde atores comparecem com suas falas decoradas para executar um roteiro rigidamente definido, também seria inadequado.

Portanto, o diretor teria de buscar outra opção. A terceira hipótese deste trabalho é que tal "opção" foi a representação épicodialética, utilizada por Altman tanto como forma de organização de seus colaboradores no set quanto como estratégia de montagem. Não é possível 
precisar se a representação épica chega a Altman diretamente, por meio da tradição teatral brechtiana. Porém, é possível identificar, na sua cinematografia, influências do que há de mais sofisticado no romance moderno e contemporâneo. Pauline Kael afirmou que o diretor "tem aquilo que Joyce tinha: um amor pelo lado suculento da vida cotidiana." ${ }^{2}$ Michael Klein, sublinhou semelhanças entre o filme e o romance U.S.A., de John dos Passos, além de chamar a atenção para o distanciamento brechtiano no trabalho de direção dos atores:

"Nashville (assim como o romance U.S.A., de John dos Passos) é uma montagem narrativa não linear sobre os Estados Unidos que assume um ponto de vista solidário em relação às personagens, representadas como vítimas de um deslocamento cultural induzido pelo capitalismo. Conforme as raízes do povo na semissubsistência (agrária/pequenoburguesa) são arrancadas pela marcha do capital monopolista e financeiro, as personagens são oprimidas pela inversão de valores humanos e pela idealização de relações familiares ligadas ao passado. [...] O modo como Altman dirige os atores contribui para um estilo brechtiano de distanciamento irônico. Como o elenco foi encorajado a compor partes do seu texto e a improvisar outras, eles tendem a atuar em um registro realista exagerado, próximo da estilização simbólica. Isto é particularmente perceptível nas cenas de multidão, nas quais muitos dos atores no segundo plano atuam com a mesma intensidade daqueles no primeiro, produzindo imagens que são uma mistura de documentário e cabaré."13

Porém, o mais certo é que as influências literárias de Nashville tenham vindo principalmente de dois escritores contemporâneos, e amigos, de Altman: Kurt Vonnegut e E. L. Doctorow. Ambos reagiram entusiasmadamente ao lançamento do filme; Doctorow afirmara, em tom enigmático, que via, pela primeira vez, "um filme que também funciona como um ato de profecia", enquanto Vonnegut, em um artigo publicado à época do lançamento, enfatizara a importância cultural e política da obra: "eu sonho que as artes possam ser úteis em épocas socialmente atribuladas. [...]. Nashville [...] realiza meu sonho."14 Se atentarmos, por exemplo, para a heterogeneidade material da sequência de abertura do filme (caricatura, linguagem publicitária,

\footnotetext{
12 KAEL, Pauline. Coming: "Nashville". in: Reeling: film writings, 1972 - 1975. p. 450.

${ }^{13}$ KLEIN, Michael. Nashville and the American dream. Jump Cut, n. 9, 1975. (versão online).
} 
animação, música, texto), na qual se advinha a técnica da colagem, largamente empregada pela representação épica no teatro e no romance moderno, descobriremos ecos da alternância de texto impresso, trechos manuscritos e desenhos no Breakfast of Champions, que Vonnegut publicara em 1973. Do desdém pela intriga rígida e pela construção orgânica do enredo, privilegiando, em vez disso, a narrativa em forma de mosaico, composta por uma série de histórias incompletas, que às vezes se cruzam, emerge um método de montagem parecido com aquele empregado por Doctorow em Ragtime, de 1974. Assim como esses romancistas, Altman tinha a ambição de produzir uma visão de conjunto da "América" e é possível que tenha absorvido deles os elementos de uma visão épica da representação, muito próxima da tradição brechtiana.

Nas afirmações que se seguem, Altman descreve como organizou a fábula de Onde os Homens são Homens (McCabe \& Mrs. Miller, 1971); trocando-se uma ou outra referência ao filme, o texto desta entrevista parece ter saído de um ensaio didático de Brecht:

"A fábula tornou-se apenas um varal em que eu ia pendurando os meus próprios ensaios. O público reconhecia tipos tradicionais - a prostituta, os assassinos contratados - de modo que eu não precisava perder tempo desenvolvendo-os. Em vez disso, eu podia dizer: você pensa que já conhece esta história, mas não conhece, porque a parte mais interessante dela está nas suas bordas." ${ }^{15}$

O número de atores empregados em Nashville e a ambição crítica do projeto inteiro obrigaram Altman a elevar seus experimentos com personagens tipificadas e um enredo episódico a um novo patamar. Retratando a inserção de vinte e quatro personagens no sistema político, econômico e cultural de Nashville, o filme não poderia aprofundar-se no desenvolvimento psicológico de nenhuma delas. Em vez disso, optou-se por apresentá-las como tipos, caracterizando-as de tal modo que pudessem ser identificadas, rapidamente, na sua relação com o tema geral: as estrelas da

\footnotetext{
${ }_{14}^{14}$ Apud HARRY, Lou. Nashville. Gadfly, n. 6 v. 4. p. 36.

${ }^{15}$ STERRITT, David (ed.). Robert Altman: interviews. p. 196.
} 
música, os principiantes, os excluídos, os dirigentes, os intermediários. Do roteiro original de Joan Tewkesbury, Altman praticamente só preservou a linha de enredo principal: as etapas de preparação de um comício para um candidato independente à presidência da república. No mais, sua direção se limitou a criar grandes cenas de conjunto, instruir os atores sobre as características gerais de seus papéis e a deixar que improvisassem suas falas. O material captado nestas filmagens era vasto e heterogêneo, não podendo ser organizado em uma narrativa convencional. A solução foi agrupá-lo em "quadros temáticos", quase nunca conectados por relações temporais; o resultado é um grande mosaico contraditório, cujas partes funcionam como ensaios semi-independentes que, "além do seu valor para o todo", têm também "um valor próprio, episódico."16

O primeiro exemplo de refuncionalização de clichês no filme é a própria sequência de abertura. Por meio dela, reapropriam-se técnicas como colagem, propaganda e distanciamento, que a publicidade havia "expropriado" para os objetivos da venda. Com certa dose de fatalismo, Roberto Schwarz fez o reconhecimento deste "sequestro" da arte pela indústria cultural, em um conhecido questionamento da atualidade da representação épica; segundo o crítico:

"É fácil notar o uso que a publicidade tem feito dos resultados mais sensacionais da arte de vanguarda, entre eles os recursos do ator brechtiano. O ganho em inteligência representado pelo distanciamento, concebido outrora para estimular a crítica e liberar a escolha social, troca de sinal sobre o novo pano de fundo de consumismo generalizado [...]. Depois de haver sido um chamado à emancipação, a insistência no caráter social e não natural da engrenagem que nos condiciona passou a funcionar, paradoxalmente, em parte talvez por uma questão de tamanho, como um dissuasivo."17

Evidentemente, não se pode pretender que Nashville seja uma resposta às dúvidas lançadas por Schwarz; porém, tampouco se pode deixar de notar que, ao incorporar criticamente a linguagem publicitária, o filme

${ }^{16}$ BENJAMIN, Walter. Que é teatro épico? Um estudo sobre Brecht. in: Magia e Técnica, Arte e Política. p. 83. 
recupera, para os objetivos da expressão e do distanciamento, parte destas formas sequestradas e esvaziadas.

Por meio de um falso comercial, a narração produz, de partida, um "efeito de estranhamento" das nossas expectativas de um filme de ficção. Se, na "retórica ficcional", as sequências de créditos visam a promover uma transição suave entre a realidade empírica e o tecido da ficção, do ponto de vida do marketing, essas sequências nunca foram outra coisa senão comerciais dos próprios filmes. Nesta complementaridade entre o impulso que visa instaurar a "ilusão de realidade" e o esforço de despertar o desejo de consumir, a música, com sua tridimensionalidade (sua existência na ficção e ao redor do espectador), sempre foi usada como uma ferramenta retórica:

"Hoje, o rugir do leão da MGM revela o segredo de toda música para cinema: um sentimento de triunfo pelo fato de o filme e sua música terem sido produzidos. A música estabelece o tom e o entusiasmo que o filme deverá encorajar no público. Sua forma básica é a fanfarra, coisa que o ritual dos 'créditos de abertura' exibe de maneira inconfundível. Sua ação não é nada mais do que publicidade. Esta música aponta, com concordância exata, para tudo o que ocorre na tela, criando a ilusão de que tudo aquilo que o filme inteiro tem de provar já está provado. Ocasionalmente, por meio de configurações padronizadas, a música interpreta o sentido da ação para os espectadores menos inteligentes, mais ou menos como remédios patenteados são promovidos por meio de explicações pseudocientíficas. [...]. Às vezes, é como se a música substituísse artigos comerciais que os filmes ainda não se atrevem a mencionar diretamente." ${ }^{\prime 18}$

Ao apresentar sua sequência de créditos como um comercial, Nashville expõe a função de publicidade, de marketing, que tais introduções ao universo diegético sempre tiveram. Literalmente "explodindo" na tela escura e na trilha silenciosa, os créditos de abertura do filme não apenas não propõem uma transição mistificadora entre a realidade e a ficção, como "escancaram" seu status de artefato, de "coisa" montada, oferecida à análise e à crítica do espectador. Em vez de trazer um leitmotiv com o qual a atitude passiva

17 SCHWARZ, Roberto. Altos e baixos da atualidade de Brecht. In. Sequências Brasileiras. p. $130-131$.

${ }^{18}$ ADORNO, Theodor W. \& EISLER, Hanns. Composing for the Films. p. 40. 
do espectador possa identificar-se, o fundo musical da sequência, composto por um pot-pourri de fragmentos elaborados pelos próprios atores, serve para manter-nos alertas e distanciados: antes de sermos absorvidos por uma determinada canção, somos "bombardeados" por um novo trecho, com qualidade, ritmo e cantor distintos.

$\mathrm{Na}$ "disputa" entre as canções e a voz do locutor que anuncia o filme, é antecipado o modo como a música e as cenas dialogadas são relacionadas pela narração. Stephen Bowles observou que, na medida em que intercala uma série de apresentações musicais a suas cenas, o filme deve ser lido a partir das categorias do gênero musical. Comparando-o com Cabaret (Bob Fosse, 1972), o crítico argumenta que

"Os dois filmes oferecem uma análise introspectiva e subestimada de um lugar específico em um momento histórico específico. Cabaret recria os hábitos e atitudes da Berlim dos anos 1930 e Nashville faz o mesmo no que diz respeito ao centro contemporâneo da música country \& western nos EUA. Tal análise é levada a cabo em ambos os filmes pela utilização cuidadosa de canções que servem de contraponto irônico a personagens e situações." ${ }^{19}$

Rick Altman também defende que Nashville seja analisado em referência às convenções do musical, não porque o filme subscreva a elas, mas sim porque as desmonta ideologicamente; para o crítico, Nashville é o filme que primeiro expôs, de modo consciente, as

"fundações paradoxais, situadas entre a arte e a cultura de massas, do musical folk, revelando as contradições, os pressupostos falsos e os autoenganos desse gênero. [...]. Nashville é também uma celebração de aniversário autoconsciente, mas longe de celebrar vitórias e unidade, o filme oferece, no bicentenário da Independência, um relato da derrota no Vietnã e da desintegração comercial da música popular norte-americana. Nashville não é apenas um filme cujas canções não resultam em um musical por conta de falta de alegria ou encenação apropriada; o filme é uma desconstrução, ponto a ponto, brilhantemente calculada, do musical folk. Praticamente todos os princípios básicos do subgênero musical folk

${ }^{19}$ BOWLES, Stephen E. Cabaret and Nashville: the musical as social comment. p. 550. 
são virados de ponta-cabeça pelas narrativas múltiplas que compõem este filme difícil e inovador." 20

Para Thomas Elsaesser, "Nashville pertence ao gênero de musical em que a intriga é estruturada pelo espetáculo que se monta", quer dizer, a organização do show que conclui o filme cria uma série de oportunidades para números musicais que vão, pouco a pouco, desmascarando as próprias condições de montagem daquele show. Trata-se, segundo o crítico, de um trabalho de "desdramatização da intriga e do relato, corrente em certo cinema europeu, mas muito rara no cinema 'liberal' norte-americano." ${ }^{21}$ De fato, a música no filme é usada como recurso épico de distanciamento irônico da cena e das personagens e é neste sentido que ela os desdramatiza. Por meio da montagem rigorosa de Altman, a música em Nashville é normalmente um contraponto irônico, e nunca uma intensificação, das emoções das personagens em cena.

A despeito de ter sido economicamente derrotado pela imposição do high concept a partir de 1975, o modelo de produção cultural criado pelo projeto de Nashville constitui uma vitória da representação épica dentro do aparato hollywoodiano. Em um artigo da época, Hollis Alpert entendeu que, com esse filme, Altman "produziu algo importante e, talvez, grandioso; ele criou uma experiência, um artefato cultural e certamente moveu o cinema americano para um plano mais elevado."22 Passados quase quarenta anos de seu lançamento, o filme permanece como uma prova monumental do nível de realização de que são capazes os artistas e técnicos empregados na indústria cultural, quando se organizam para garantir os meios necessários à sua expressão.

O presente trabalho se volta para este filme com o intuito de retirar lições que nos ajudem a compreender o momento em que foi

${ }^{20}$ ALTMAN, Rick. The American Film Musical. p. $323-324$

${ }^{21}$ ELSAESSER, Thomas. Où finit le spectacle?... (à propos de "Nashville"). p. 24.

${ }^{22}$ ALPERT, Hollis. The homecoming of Barbara Jean. Saturday Review, n. 2, 28/06/1975, p. 40. 
produzido, mas que também sirvam de encorajamento para aqueles que acreditam na atualidade da representação épica. A tese que orienta a análise é a de que Nashville é uma tentativa de representar, a partir da cidade da música country, os processos de desmanche da experiência política, cultural e social nos EUA, na primeira metade dos anos 1970. Duas hipóteses se deduzem da tese e deverão ser testadas na continuação da análise: a primeira é de que Altman se apropriou de técnicas, formas e clichês da indústria, modificando-os para viabilizar sua visão crítica e seu método de trabalho; a segunda é de que tais elementos refuncionalizados resultaram em um "épico possível" nas condições de produção norte-americanas.

Para facilitar a abordagem crítica do filme, nossa análise buscou espelhar, de modo aproximativo, a sua própria organização; assim, a exposição da tese foi dividida em capítulos que, a despeito de sua função no conjunto, têm também um valor individual, podendo, inclusive, serem lidos separadamente. Nesta introdução, tentamos reconstruir, em uma interlocução com a fortuna crítica, as condições de produção de Nashville e definir seu posicionamento em relação ao modelo de cinema industrial que se assentava à época. No segundo capítulo, analisamos o primeiro quadro temático do filme, sublinhando o modo como estão representadas as relações entre política e cultura na esfera privada da produção e na esfera pública da circulação. O capítulo seguinte trata das modificações trazidas pelo capital fonográfico à cidade de Nashville, bem como das consequências políticas da ocupação do espaço público pelos negócios country. A longa seção intermediária, que mapeia os aspectos contraditórios do funcionamento do aparato country em Nashville, é o tema do quarto capítulo. As três longas sequências antepostas ao último "ensaio" do filme mereceram, por conta do papel que desempenham na exposição do argumento geral, um capítulo separado. Finalmente, no capítulo 6 , fazemos a "leitura cerrada" de toda a sequência final; como ela retoma e resume várias das questões apresentadas ao longo do filme, utilizamos a sua análise para recuperar, a partir de um novo 
diálogo com a fortuna crítica, os passos da exposição da tese e encaminhar o trabalho para uma conclusão. 


\section{2: country music é política}

O primeiro "ensaio" do filme, composto de duas sequências relativamente longas, apresenta e encaminha o desenvolvimento do tema geral: as relações entre política e produção industrial da cultura. O recorte escolhido são as sobreposições entre a campanha de um candidato à presidência e a indústria fonográfica na cidade de Nashville. Do ponto de vista formal, este primeiro quadro temático ainda serve de exposição das coordenadas de tempo e espaço para a narrativa, além de trazer uma reflexão sobre o lugar do espectador na recepção do filme. Ao final do quadro, é possível ter uma ideia mais clara do tema geral, assim como das formas dialéticas necessárias a sua representação.

A primeira sequência do quadro é também aquela que nos traz os movimentos iniciais de enunciação do universo diegético. Nela, nosso olhar segue um furgão decorado com o material de campanha de Hal Philip Walker, candidato à presidência dos EUA, pelo Partido da Substituição (Replacement Party). A apresentação de Walker se dá primeiro na trilha sonora, na forma de uma voz sem corpo e sem antecedentes, sobreposta diretamente à tela escura. Na continuação, a imagem residual do título do filme, deixada pelo "comercial" com os créditos de abertura, se funde com slogans políticos pintados sobre o portão de um comitê de campanha: "Tennessee Headquarters", "Nashville", "Walker.Talker.Sleeper". Tais inscrições criam coordenadas geográficas para o espaço narrativo (a cidade de Nashville, no estado norteamericano do Tennessee), enquanto a fusão entre a referência histórica (a campanha presidencial) e a exposição visual do título do filme sublinha o fato de que se trata da História "ficcionalizada". O branco do portão contrasta com o vermelho da parede de tijolos que o rodeia, dando a impressão de uma cortina (como no teatro) ou mesmo evocando a imagem da "claquete" que se coloca 
como marcação no começo de cada tomada no cinema. ${ }^{23}$ O levantamento do portão frustra nossa expectativa de descobrir a fonte humana da voz que paira sobre a imagem; em vez disso, o que aparece é o suporte técnico em que ela foi registrada e a partir do qual é emitida: o sistema de som montado sobre um furgão branco em que se lê um slogan de campanha - "Novas raízes para a nação".

O carro de som sai do campo, atraindo o olhar da câmera, que passa a persegui-lo em seu caminho pelas ruas de um bairro central. De seu megafone, ele emite um discurso político:

"Companheiros contribuintes e acionistas da América. $\mathrm{Na}$ primeira terça-feira de novembro, teremos de tomar algumas decisões cruciais a respeito da gestão do país. Permitam-me ir direto ao ponto: eu sou a favor de fazer algumas substituições. Eu tenho explicado o que é o Partido da Substituição a pessoas de todos os cantos do país e constantemente deparo com os seguintes depoimentos: 'Eu não me meto em política' ou 'Eu estou cansado de política' ou 'A política não me interessa'. Nas mesmas situações, há sempre alguém que diga: De qualquer maneira, não está ao meu alcance fazer nada mesmo. Deixemme esclarecer dois pontos: número um, todos estamos profundamente envolvidos na política, quer saibamos ou não, quer gostemos ou não; e número dois, nós podemos, sim, fazer alguma coisa a respeito. É de política que se trata quando se paga mais por um automóvel do que a quantia que Colombo precisou para fazer sua primeira viagem à América."

Estranhamente, os movimentos que o furgão executa entre a frente e o fundo da imagem não são acompanhados pela trilha sonora, na qual a voz gravada permanece monotonamente em primeiro plano. A parada do veículo no semáforo de uma grande avenida coincide com um aviso no meio do discurso ("deixem-me esclarecer dois pontos"), acompanhado de uma pontuação sonora: dois toques na buzina de um Volkswagen no meio do trânsito. Essa sincronia entre o texto do candidato em campanha e efeitos sonoros incluídos no processo de mixagem deve ser encarada como um

23 "Quando a história começa, é de um modo silencioso, como um lembrete de que as origens do cinema, e deste filme em particular, se encontram no silêncio e no teatro. A cortina literalmente se ergue, com a fusão do título isolado, Nashville, sobreposto a um portão de garagem que se 
"reconhecimento" indireto do trabalho de narração, que intervém na trilha para ressaltar um determinado trecho e orientar a atenção do espectador. Neste ponto, a mixagem, até então dominada pela voz gravada, é "povoada" por outras fontes: efeitos sonoros reproduzindo o barulho da rua e a introdução do número musical que veremos na próxima tomada. Em seu fechamento, a sequência cria uma sincronia no nível da composição: se, no plano da trilha sonora, a voz do político em campanha se mistura a outras fontes, no arranjo visual do quadro, a sua representação (o carro de som) torna-se uma imagem no meio de várias outras (veículos, fachadas de edifícios, publicidade).

A parada do carro de som no semáforo dá ao espectador a oportunidade de apreciar mais detalhadamente a organização de imagens e sons no quadro. A partir de uma tomada por trás do furgão, o foco narrativo "abre o campo", revelando o movimento de vaivém dos automóveis. $O$ lugar onde se posiciona o "olhar da câmera" (o meio da avenida, provavelmente em uma grua) não reproduz um "olhar possível" dentro da ficção, o que instaura um "narrador" externo à cena, que só interfere nos acontecimentos narrados de modo indireto (por exemplo, com os efeitos sonoros de buzina). A avenida termina em um entroncamento, sobre o qual está colocado um enorme outdoor em que se lê "The Bank". Por conta de um efeito de "achatamento da imagem", provavelmente produzido pelo uso da lente teleobjetiva, o outdoor é posto no mesmo plano visual do furgão, estabelecendo-se assim uma equivalência formal entre os dois elementos ${ }^{24}$. $\mathrm{Na}$ lateral da imagem, é possível discernir ainda uma placa identificando um edifício: "The First Bank of America". O quadro conclui a sequência, finalizando também o primeiro movimento de enunciação do espaço narrativo, cujo recorte selecionado - a porção da cidade dedicada aos negócios financeiros - é então associado, no nível da composição visual e sonora, a um tema geral a ser desenvolvido a partir daqui: os diversos entrelaçamentos da

abre, tornando-se então parte do mundo físico da cidade." KEYSSAR, Helene Keyssar. Robert Altman's America. p. 138.

${ }^{24}$ Segundo Solange Grossi, a "lente teleobjetiva provoca o achatamento da imagem, ou seja, há a perda de profundidade; o plano de fundo e o primeiro plano são apresentados num único plano, criando um efeito de superficialidade." in: Short Cuts de Robert Altman. p. 44. 
política com a economia (as instituições financeiras representadas) pela mediação dos processos de produção e circulação de imagens.

Uma boa parte da exposição desse tema é adiantada na própria sequência, começando pela forma de expressão e difusão da fala de Walker, o político em campanha. Numa cidade que vive da produção e venda de música "acusmática" ${ }^{25}$, a campanha de Walker privilegia o meio acústico para produzir e veicular imagens destinadas a fascinar e a conquistar a adesão dos eleitores. A combinação entre a circulação por meio técnico com o apelo ao sentido da audição é uma traço da forma estética das mercadorias culturais difundidas pela indústria fonográfica e pelo rádio. Ao adotar esta forma estética comercial, a fala política adquire a mobilidade própria da mercadoria: por um lado, a possibilidade de copiar-se indefinidamente aumenta a extensão de seu alcance; além disso, a ausência de um corpo que a aprisione dificulta a recuperação de explicações sobre a origem e os limites do comando que ela contém. Em outras palavras, sem um contexto que o relativize, o comando da voz gravada assume um aparente valor absoluto. Finalmente, por ser difundida por um meio técnico unilateral, esta voz estetizada tem a "vantagem" adicional de propor um diálogo com o ouvinte, "adoçando" o seu comando, sem, no entanto, permitir réplica, configurando assim a forma retórica perfeita para uma intenção política autoritária que visa, no entanto, passar por democrática ${ }^{26}$. Por outro lado, a adoção desta forma não se dá sem consequências indesejáveis para a pessoa do político, que passa a valer como mais um produto de mídia, sujeito às mesmas "angústias" que "aterrorizam" a mercadoria: a obsolescência,

\footnotetext{
${ }^{25}$ O termo "acusmático" é empregado por Michel Chion para designar "um som que é ouvido sem que sua causa ou fonte seja vista"'. in: The Voice in Cinema. p. 18.

${ }^{26}$ Adorno e Horkheimer reconheceram esta afinidade entre meios de produzir e vender cultura e as estratégias políticas de tendências totalitárias, afirmando que, por exemplo, ao apresentar a voz do político fascista na "forma de uma autoridade desinteressada", o rádio se torna "a voz universal do Fuhrer; nos autofalantes de rua, sua voz se transforma no uivo das sirenes anunciando o pânico, das quais, aliás, a propaganda moderna é difícil de se distinguir. Os próprios nacional-socialistas sabiam que o rádio dera forma à sua causa, do mesmo modo que a imprensa fizera para a Reforma. [...]. Colocar a palavra humana como algo de absoluto, como um falso imperativo, é a tendência imanente do rádio. A recomendação transforma-se em um comando. [...]. O Fuhrer ordena de maneira mais moderna e sem maior cerimônia tanto o holocausto quanto a compra de bugigangas." in: A Dialética do Esclarecimento. p. 149 - 150.
} 
o desinteresse público, a falta de "market appeal". Se a arena política de onde ele fala identificou-se ao mercado, seu esforço retórico não pode limitar-se a convencer sobre a veracidade de suas promessas; é preciso também despertar o desejo de consumi-lo como imagem. Transformado em produto veiculado pelo aparato das indústrias culturais, o político deve provar sua desenvoltura dentro deste aparato; em outras palavras, ele agora tem de sair vitorioso não apenas na arena política, mas também no mercado, com o qual ela se identificou. ${ }^{27}$

O foco narrativo sublinha estes problemas conferindo a Walker um "status ficcional" instável: durante todo o filme, a fonte original de sua voz permanece oculta, de modo que ele não chega a fazer a passagem de uma existência puramente "midiática", uma imagem surgida da sobreposição de diversos discursos (notícias de televisão, campanha gravada, pôsteres, panfletos, boatos, etc.), para tornar-se uma figura "tangível", um personagem fílmico completo, com voz e corpo representados ${ }^{28}$. Além disso, circulando em um espaço saturado de imagens atraentes, os argumentos contidos em sua fala disputam a atenção pública com a sedução de suas "adversárias no mercado". Em outras palavras, para um público cujas exigências políticas se confundiram com exigências de consumo, a fala de Walker corre o risco de parecer monótona, desinteressante, ou até mesmo irrelevante. Talvez, o fato de que

\footnotetext{
${ }^{27}$ Esta nova realidade do mercado como um campo de disputas políticas não deixou de chamar a atenção de Walter Benjamin, que nos trouxe uma visão mais completa dos desafios representados pelos novos meios de produção industrial e difusão da cultura. Assim como Adorno e Horkheimer, Benjamin não deixou de reconhecer que os novos meios técnicos impunham uma seleção política, um processo "de seleção diante do aparelho, do qual emergem, como vencedores, o campeão, o astro e o ditador". Porém, Benjamin não encara esta nova realidade da "seleção diante do aparato" com fatalismo; em vez disso, descobre aí um desafio político: se o fascismo emprega a técnica para dar uma forma estética a sua dominação, Benjamin lembra que "o comunismo responde com a politização da arte", disputando a apropriação e os usos de seus meios de produção. BENJAMIN, Walter. A obra de arte na era de sua reprodutibilidade técnica. in: Magia e Técnica, Arte e Política. p. 183 e 196.

${ }_{28}$ Neste sentido, mais do que um simples "som acusmático", a voz de Walker identifica um "personagem acusmático", ou, nas palavras de Michel Chion, um "acousmêtre". Trata-se de um personagem "cuja relação com a tela envolve um tipo específico de ambiguidade e oscilação [...]. Podemos defini-lo como nem dentro nem fora da imagem. Ele não está dentro porque a imagem da fonte da voz - a boca, o corpo - não está incluída. Tampouco está fora, pois não está claramente posicionado em uma 'ala' exterior imaginária, como estão o mestre de cerimônias ou a testemunha; trata-se de um personagem que está implicado na ação, constantemente a ponto de tomar parte nela." in: Audio-Vision. p. 129.
} 
nenhum transeunte na avenida se detenha para ouvi-la seja um indicador de que é exatamente assim que ela é percebida ${ }^{29}$.

Apesar de anunciar-se como uma opção inovadora aos partidos constituídos, Walker representa uma posição liberal conservadora, cujo ideal "democrático" é o de uma sociabilidade desembaraçada de relações políticas e regida apenas pelas leis do mercado. Este posicionamento de fundo no seu discurso vem à frente no modo como ele põe, linguisticamente, o seu ouvinte: "Companheiros contribuintes e acionistas da América". A formulação desse vocativo, que instaura um ouvinte dividido em dois blocos opostos, reduz a comunidade política a meras funções da economia financeira e a esvazia das contradições e afiliações que a tornam inteligível; pelo menos no plano discursivo, Walker realiza o sonho de uma sobreposição total entre sociedade e mercado.

Neste sentido, o ato de fala que põe a comunidade política é o mesmo que a suprime, dando a ela uma feição abstrata e apaziguada; afinal, independentemente do lugar ocupado nas finanças do país, os destinatários da mensagem são todos unificados como "companheiros" de Walker. Entretanto, esta tentativa de controlar a realidade social por meio do discurso não vai além do próprio ato de fala; nos carros circulando pela avenida e nas instituições bancárias enfileiradas ao longo das calçadas, onde se encontram os "acionistas e contribuintes da América", a vida cotidiana segue seu

\footnotetext{
${ }^{29}$ Assim como seus predecessores frankfurtianos, Neil Postman atribui essa irrelevância contemporânea do discurso público à mudança do suporte técnico de sua veiculação: do texto escrito (ou da fala que imitava o texto escrito) para os meios audiovisuais. A origem desta grande mudança de paradigma pode ser encontrada, segundo Postman, no século XIX, com a invenção do telégrafo e a abertura da possibilidade histórica de que a "fala pública" fosse transformada em "notícia" e vendida como uma mercadoria. Segundo Postman, "o telégrafo atacou a definição tipográfica do discurso com a introdução de três ingredientes em larga escala: irrelevância, impotência e incoerência. Estas três ameaças ao discurso foram despertadas pelo fato de que a telegrafia deu uma forma de legitimidade à ideia de informação sem contexto [uma versão degradada da informação descontextualizada], ou seja, a ideia de que o valor da informação não precisa estar atrelado a qualquer função que ela possa servir na tomada de decisões e na ação política, mas apenas deduzida da novidade, do interesse e da curiosidade que ela possa despertar. O telégrafo transformou a informação em mercadoria, em uma 'coisa' que pode ser comprada e vendida a despeito de seus usos ou sentidos." in: Amusing Ourselves to Death. p. 65.
} 
caminho a portas fechadas, alheia ao comando que tenta suprimi-la. Cria-se, assim, um desencontro entre a experiência política estetizada pela forma mercantil e sua efetiva capacidade de influir na vida prática.

O trabalho de reelaboração da política pelo vocabulário da economia tem continuidade na alusão à carestia: "É de política que se trata quando se paga mais por um automóvel do que a quantia que Colombo precisou para fazer sua primeira viagem à América". Alertando para uma sobreposição entre política e economia que seu próprio discurso ajuda a fixar, o candidato à presidência vai "cercando" seu ouvinte, dando a entender que a experiência política é uma realidade tão inescapável quanto a própria vivência econômica: "todos estamos profundamente envolvidos na política, quer saibamos ou não, quer gostemos ou não".

Diane Pecknold não deixou de notar, no desmanche da experiência política figurado no discurso de Walker, ressonâncias do processo de generalização do consumismo na sociedade norte-americana do pós-guerra:

"Uma boa parte da exploração que o filme realiza sobre o impacto do comercialismo na vida americana é transmitida no peculiar monólogo impressionista de Hal Phillip Walker [...]. Walker nunca aparece na tela [...]. Porém, sua voz se faz presente ao longo do filme a partir de um carro de som de campanha, sempre enfatizando a redução da cidadania ao consumismo. [...] a mensagem de Walker justapõe o vazio da política como uma forma de propaganda comercial e repetidos gestos na direção da dimensão moral subjacente à troca econômica. 'Nada vem de graça'; é o que a voz sem corpo de Walker entoa em uma das poucas cesuras na atribulada paisagem sonora do filme, lembrando que os americanos não são inteiramente inconscientes da barganha política e cultural que a sociedade de consumo requer. Mesmo a justiça prometida por Walker é representada como um processo de troca e contabilidade: 'se é preciso fazer o balanço do livro-caixa', ele aconselha, 'somos nós que o teremos de fazer."”30

Entretanto, o interesse do conteúdo do discurso de Walker para a análise fílmica não se resume ao fato de que ele ilustra a 
generalização da forma-mercadoria na vida social norte-americana. Além de figurar o processo histórico mais amplo, ele também funciona como dispositivo de exposição do ponto de vista narrativo em relação a acontecimentos pontuais, próximos do momento de produção e lançamento do filme. Ao fazer alusão às eleições presidenciais de 1976 ("a primeira terça-feira de novembro"), sua fala completa a amarração dos acontecimentos ficcionais à história norte-americana, iniciada pela inscrição no portão do comitê de campanha. Localizando a diegese nos meses que antecedem as eleições de 1976, este trecho explicita a "defasagem" entre o "presente" da narração (o filme é rodado em 1974 e lançado em 1975) e os acontecimentos representados.

É preciso lembrar ainda que, no momento de produção e no primeiro ano de exibição de Nashville, a política e as eleições eram os assuntos favoritos das mídias, incluindo o cinema. Só para lembrar alguns dos acontecimentos que agitaram o país neste período, podemos citar: 0 escândalo de Watergate, a renúncia de Nixon, o comando do país assumido por Gerald Ford, um vice-presidente não eleito (Spiro Agnew, o vice-presidente legítimo, havia renunciado, um ano antes, após acusações de fraude, extorsão, suborno e conspiração) e a corrida presidencial que acabaria com a vitória de Jimmy Carter. Portanto, o "público ideal" do filme não apenas estava familiarizado com o tema como incluía eleitores em processo de preparação para as eleições. Deste modo, ao "narrativizar" as futuras eleições, o filme significava, para o espectador da época, tanto uma oportunidade de fruir uma boa história quanto uma continuação dos debates mais gerais que orientariam, dois anos depois, uma opção política. É neste sentido que a explicitação da perspectiva temporal na cena tem também o valor de exposição de um ponto de vista ideológico sobre o assunto narrado, que vem na forma de crítica de um modo de fazer política e um aviso sobre o que ele poderia representar nas eleições de 1976.

${ }^{30}$ PECKNOLD, Diane. The Selling Sound. p. $229-230$. 
Talvez correndo o risco de "forçar" a interpretação, pode-se entrever, por trás da ação narrativa de definir a defasagem temporal entre discurso e história, uma tentativa de reverter o desinteresse de uma parcela da população em relação ao processo eleitoral, apontado por muitos como uma das causas da ascensão da direita no final dos anos 1960. Em uma análise deste processo, Mike Davis afirma que

"em nenhum outro país capitalista, o absenteísmo político em massa é tão desenvolvido quanto nos Estados Unidos, onde uma 'maioria silenciosa' da classe trabalhadora não participou de mais da metade das eleições no século XX. Provavelmente, este protesto mudo e atomizado é o correlato histórico da surpreendente falta de um partido político proletário independente no país que inventou tanto o partido trabalhista quanto o dia do trabalho." 31

Neste sentido, Walker funcionaria como o meio de expressão indireta de um "autor implícito" que, em porções do discurso gravado do personagem, emite uma visão do estado das relações políticas e conclama o público de cinema a comparecer às urnas e a deter a ascensão de figuras como o próprio Walker: "nós podemos sim fazer alguma coisa a respeito".

Se esta primeira sequência do quadro temático explora a relação imbricada entre política e economia a partir de seus resultados, quer dizer, quando o político já passou pelo aparato industrial e circula no mercado de imagens como um objeto estético, os passos seguintes localizam suas causas no espaço da produção, o que significa uma "virada prismática" do "olhar narrador". Saindo da esfera de circulação da cultura industrializada (a avenida no distrito financeiro), o foco narrativo joga luz sobre o ambiente fechado do trabalho: um estúdio de gravação onde contradições políticas precisam ser elaboradas cotidianamente pela práxis material. O redirecionamento do "olhar narrador" se reflete na própria forma de captação das imagens: dos planos abertos e longos do carro de som circulando na avenida, mais adequados a uma visão sintética do "político em circulação", passa-se a

${ }^{31}$ DAVIS, Mike. Prisoners of the American Dream. p. 3. 
planos mais próximos e curtos, sugerindo a mediação de um olhar analítico, que busca observar a questão de fundo nos seus elementos particulares.

Estas duas formas polares de tratar o assunto são articuladas pela trilha sonora, que sobrepõe os acordes iniciais de um número musical country às últimas imagens do carro de som de Walker. $O$ efeito resultante é o de uma ligação temática (o político na avenida - o tema country que se anuncia) sem a qual as duas sequências, que não têm nenhuma relação de continuidade temporal ou espacial, permaneceriam isoladas na montagem. Fazendo uma analogia sintática, pode-se dizer que não há relação de subordinação entre as duas sequências (a primeira não introduz a segunda, nem esta explicita aquela); elas se juntam por um princípio de coordenação simples, amarradas apenas pelo elemento acústico. ${ }^{32}$

Conforme a câmera varre o espaço do estúdio, descobrimos que o tema country era a introdução de "200 Years", uma canção patriótica em comemoração ao bicentenário da independência (celebrado em 1976), gravada por Haven Hamilton, um astro local, e sua equipe de músicos e técnicos contratados. Tudo corre bem até a chegada de Opal, uma documentarista a serviço da BBC, que tenta, sem sucesso, fazer uma entrevista

\footnotetext{
${ }^{32}$ Helene Keyssar já havia feito uma avaliação mais ou menos neste sentido do recurso de ligação entre as duas sequências: "As imagens visuais do carro de som e do estúdio de gravação não são conectadas nem por personagens nem por locação; falando nos termos da montagem, são imagens que 'colidem'. O problema com este tipo de colisão em muitos filmes é o fato de que a síntese perceptiva almejada é frequentemente óbvia demais, a ponto de ser embaraçosa, ou obscura demais, a ponto de não fazer sentido algum. Ao iniciar com a canção de Haven em uma sequência visual para continuá-la em outra, Altman tanto carrega nossa resposta emocional de um ponto a outro quanto permite que a ligação intelectual seja constante sem ser pesada." in: Robert Altman's America. p. 138 - 139. Evidentemente, seria possível fazer uma avaliação completamente inversa do recurso à "ponte sonora" aqui, vendo nele não um sinal de radicalismo (a "colisão de imagens" de que fala Keyssar) e sim uma concessão a um princípio de "montagem fluida", na qual o som serviria como um atenuador da descontinuidade entre as duas sequências. Como nos lembra Mary Ann Doane, na montagem convencional, som e imagem raramente são "cortados exatamente no mesmo ponto. A continuação do mesmo som sobre o corte entre duas imagens desvia a atenção daquele corte. De modo similar, o processo de mixagem é caracterizado por 'um trabalho de unificação, homogeneização, atenuação e polimento de todas as arestas na trilha sonora'. Todas estas técnicas são motivadas por um desejo de desvincular o filme de sua fonte, de esconder o trabalho de sua produção. São recursos que promovem uma sensação de falta de esforço e de facilidade na captação do
} 
com Haven. Expulsa do estúdio principal, Opal é levada por Bud, filho e empresário do cantor, para conhecer o estúdio $B$, onde ocorre a gravação de um número gospel. Enquanto os dois comentam a apresentação a que assistem, voltamos ao espaço anterior.

A primeira tomada no estúdio é uma panorâmica que mapeia o trabalho rotineiro no ambiente da produção fonográfica: começando pelos músicos e seus instrumentos, cada qual em um espaço reservado, o "olhar narrador" nos apresenta Bud e Pearl, familiares e empresários de Haven, além de técnicos de som e uma pequena plateia. Mais próximos do centro do espaço cênico, três backing vocals criam o pano de fundo sonoro para a voz do star, confinado em uma cabine de vidro. Reflexos luminosos sobre a imagem dos personagens enfocados sugerem que a tomada é feita por trás de uma superfície semitransparente, provavelmente a divisória que separa o estúdio da cabine de edição e mixagem de som. O posicionamento da câmera neste provável compartimento do estúdio situa a emissão do foco narrativo e, por conseguinte, o ponto de vista e de audição do espectador, próximos de uma figura interna responsável pela direção dos trabalhos representados na cena. A partir deste ponto, o olhar panorâmico se move lateralmente até deter-se sobre Haven, aproximando-se então do personagem por meio de um close-up visual e sonoro, ou seja, com o aumento do tamanho da imagem de seu rosto e do volume de sua voz. Enquanto o personagem repete o estribilho de sua canção ("Devemos estar fazendo a coisa certa para durar duzentos anos',33), a narração projeta, do lado esquerdo do quadro, os créditos de autoria do discurso de Walker ("Political Campaign/Thomas Hal Phillips").

natural". DOANE, Mary Ann. Ideology and the practice of sound editing and mixing. in: Elisabeth Weis \& John Belton. Film Sound. p. $57-58$.

33 "We must be doing something right to last two hundred years". Para facilitar a leitura deste trabalho, optamos por traduzir para o português os trechos de canções citados no corpo do texto. Como a tradução adotada não visa a recuperar a estrutura poética das letras, mas apenas o seu sentido básico, tais citações serão acompanhadas de notas de rodapé com os versos originais, em inglês. 
Portanto, além de identificar o elenco e a equipe técnica, os créditos nesta sequência assumem uma função expositiva, a saber: eles atuam como uma "legenda épica", associando o personagem ao tema central do quadro. São, por assim dizer, um "recurso discursivo" a mais que a narração utiliza para caracterizar personagens em um contexto de trabalho, com seu modo específico de distribuir tarefas e estabelecer hierarquias e prioridades. O restante da caracterização se dá por meio do esforço cênico propriamente dito: a representação de diversos profissionais em cena (em vez de um único músico) indica que neste espaço a arte é produzida socialmente ${ }^{34}$. A fragmentação do processo inteiro em contribuições individuais, cuja soma resultará em uma mercadoria de massa (um disco country), multiplicada por um aparato técnico, caracteriza o modo de produção como industrial. $\mathrm{O}$ isolamento de cada músico em compartimentos do estúdio, a sua incapacidade de intervir na soma de todas as contribuições e a concentração de tal função em uma "figura organizadora" (o engenheiro de som, representante dos interesses do star) lembram que o trabalho aqui é administrado segundo princípios tayloristas. ${ }^{35}$ Finalmente, o estabelecimento de uma hierarquia a partir de uma das contribuições individuais, tanto na distribuição espacial das tarefas

\footnotetext{
34 "Socialmente" aqui se define em oposição a "individualmente" e não se confunde com "coletivamente". Refletindo sobre a divisão do trabalho no cinema comercial e, por extensão, nas indústrias culturais, Brecht nos ensina que não se deve descrevê-la como "coletiva" se quisermos que o termo continue a significar um tipo de produção em que os agentes "compartilhem uma noção do assunto, da proposta do filme, do público, do aparato, etc." em vez de apenas somarem seus saberes técnicos visando a produção de "entretenimento noturno". BRECHT, Bertolt. "The Threepenny Lawsuit". in: SILBERMAN, Marc (ed). Brecht on Film and Radio. p. 172.

${ }^{35} \mathrm{O}$ termo se refere aos princípios da "Organização Científica do Trabalho", formulada por Frederick Winslow Taylor (1856 - 1915). "[...] aplicados em todo o mundo industrial contemporâneo [, tais princípios] centralizam o poder de decisão nas mãos da direção, excluindo os produtores diretos da concepção e do planejamento da produção. O operário deve apenas realizar as instruções, o que supõe submeter-se às ordens impostas pela hierarquia despótica da fábrica. À direção compete dirigir, controlar e vigiar o trabalhador, impedindo por todos os meios sua articulação e comunicação horizontais no interior do mesmo espaço de produção. Localizados em seus postos, os superiores hierárquicos dispõem de um observatório através do qual analisam, classificam, registram, produzem conhecimentos sobre o subordinado, o que facilita a vigilância e o controle sobre ele." MOREIRA, Eduardo F.P. \& RAGO, Luzia Margareth. O Que é Taylorismo. p. 23 - 24. Como se pode observar, essa descrição da administração do trabalho no espaço fabril se ajusta perfeitamente à cena do estúdio em Nashville, só necessitando complementar que, no filme, um dos trabalhadores, o star, é também um "superior hierárquico" que, de sua cabine, vigia todos os demais, inclusive o próprio diretor.
} 
(colocando na cabine central o trabalho mais valorizado), quanto na harmonização e mixagem das fontes sonoras (ressaltando uma "voz de referência", a do lead singer), configura a forma histórica que a divisão taylorista do trabalho ganhou nas indústrias culturais: o star system ${ }^{36}$.

O "peso" desta hierarquia dá à cena uma "atmosfera" tensa, como se o estúdio fosse um "campo minado" prestes a disparar conflitos. Isto, porém, não ocorre, pelo menos não neste ponto da sequência, pois, assim como uma luz baixa constante confere certa unidade aos elementos cênicos, uma mixagem "ilusionista" harmoniza e apara eventuais choques entre as contribuições de cada músico.

Sobre a mixagem adotada até aqui, Rick Altman observou que ela

não é exatamente aquilo que os músicos criaram. Cada cantor e instrumentista foi amplificado, igualado e mixado na versão sintética final montada pelos engenheiros de som. Assim, o que ouvimos é uma ficção - uma harmonia suave e cuidadosamente hierarquizada pelo processo de mixagem ${ }^{37}$.

Ou seja, a narração optou por trazer ao ponto de audição do espectador não uma imagem sonora do processo de produção da música de Haven, mas uma miragem do aspecto que ela ganhará quando estiver pronta para a prensagem em disco, o que produz uma espécie de fissura entre duas formas de conhecer, pelo olhar e pelo ouvido. De fato, quando a análise fílmica separa os sons e imagens que a montagem juntou, é ressaltado

\footnotetext{
${ }^{36}$ Como observou Anatol Rosenfeld, a produção centrada na "estrela" foi uma das principais estratégias de custos que o cinema adotou na sua passagem de atividade semi-industrial para um negócio visando um mercado de massa global, pois a elaboração do filme em torno de "capital humano" consagrado pelo mercado (o star) foi uma forma de assegurar um mínimo de retorno e reduzir os riscos dos grandes investimentos necessários à produção industrial do cinema. "A gravitação comercial exige, em escala ascendente, o aproveitamento máximo dos estúdios e alta eficiência e velocidade de produção. Só assim é que o capital empatado, baseado na circulação rápida dos filmes, promete amortização segura e satisfatória. [...]. O risco, portanto, é grande e o capital procura diminuir esses riscos. O nome de uma estrela, uma propaganda bem dirigida, o conhecimento dos gostos atuais da massa (por meio de técnicas que registram a opinião), tudo isso contribui para diminuir o perigo da perda do capital." in: Cinema: arte e indústria. p. 114.
} 
um "desencontro" entre a forma visual (contribuições individuais acusticamente isoladas pelas divisórias do estúdio) e a mixagem de som (uma mistura harmonizada de tais contribuições) na cena. Do ponto de vista das regras de verossimilhança, isso configuraria uma falha, pois a sonoridade finalizada do disco de Haven, que a narração antecipa para o espectador, não pode ser deduzida de nenhum ponto de audição interno, nem sequer o do engenheiro de som pressuposto, que "trabalha", fora do campo, justamente na manipulação das fontes. Talvez seja essa a razão por que Rick Altman qualificou a mixagem neste ponto da cena como uma "ficção". Entretanto, se pensarmos tal incoerência entre imagem e som como um "efeito de estranhamento" por meio do qual a mixagem da canção de Haven é exposta como uma "falsificação" deliberada das ações encenadas, então o elemento inverossímil ganha o sentido de um procedimento artístico necessário à construção de uma visão crítica do processo de produção industrial da cultura: ao demonstrar como o trabalho dividido e tensionado em um estúdio de gravação é encoberto com uma massa sonora unificada e apaziguada, a narração sublinha a função que a mixagem de som cumpre na manutenção da forma de fetichismo peculiar à "mercadoriadisco"38. É esse fetiche que a narração desmonta ao contrapor o "efeito de naturalidade" do domínio acústico de Haven e um esforço consciente de adulteração das relações de valor entre fontes de som, sustentado por uma organização do trabalho ao redor da figura do $\operatorname{sta}^{39}$.

\footnotetext{
${ }^{37}$ ALTMAN, Rick. 24-track narrative? Robert Altman's Nashville.

38 "O conceito de fetichismo musical não se pode deduzir por meios puramente psicológicos. $\mathrm{O}$ fato de que 'valores' sejam consumidos e atraiam os afetos sobre si, sem que suas qualidades específicas sejam sequer compreendidas ou apreendidas pelo consumidor, constitui uma evidência da sua característica de mercadoria. [...]. Marx descreve o caráter fetichista da mercadoria como a veneração do que é autofabricado, o qual, por sua vez, na qualidade de valor de troca se aliena tanto do produtor como do consumidor, ou seja, do 'homem'. Escreve Marx: 'O mistério da forma mercadoria consiste simplesmente no seguinte: ela devolve aos homens, como um espelho, os caracteres sociais do seu próprio trabalho como caracteres dos próprios produtos do trabalho, como propriedades naturais e sociais dessas coisas [...]'. Este é o verdadeiro segredo do sucesso. É o mero reflexo daquilo que se paga no mercado pelo produto: a rigor, o consumidor idolatra o dinheiro que ele mesmo gastou [...]." ADORNO, Theodor W. O fetichismo na música e a regressão da audição. in: ADORNO, Theodor W.; BENJAMIN, Walter Benjamin et al. Textos Escolhidos. p. $172-173$.

${ }^{39}$ É neste sentido que talvez se possa tratar o fetichismo como uma falsificação da experiência social: no disco de Haven, a predominância de sua voz parecerá uma "característica objetiva",
} 
Entretanto, aqui é preciso questionar se o "efeito de estranhamento" visado é saliente o bastante para perturbar a recepção da cena. Parece que não. De fato, a utilização da mixagem tradicional parece antes confirmar as expectativas narrativas do ouvinte do que desafiá-las; ao privilegiar um modo de ouvir constituído a partir de mixagens que visam a tornar "inaudíveis" as suas próprias ações sobre as fontes de som, a narração corre o risco de reforçar uma eventual "surdez" do espectador para os problemas lógicos que cercam a audibilidade da cena ${ }^{40}$. Como afirmamos anteriormente, o "efeito de estranhamento" aqui se revela apenas a partir da análise deliberada da montagem entre som e imagem, ou seja, até este ponto, a narração exige um espectador extremamente atento e analítico.

Porém, no prosseguimento da cena, a narração se esforça para "alcançar" o espectador, auxiliando-o no trabalho de fragmentação da montagem por meio da introdução de um ponto de vista perturbador da harmonia entre som e imagem. Entrando lateralmente no pequeno espaço dedicado à plateia, com um gravador a tiracolo, uma jornalista atrapalha a concentração de Haven, que interrompe o número, pede que a saída de seu microfone seja aberta e repreende Bud, seu filho, por ter permitido a presença de estranhos portando equipamento de gravação. Perguntando se Haven pode ouvi-la, Opal, a jornalista, tenta explicar que trabalha para a BBC e que gostaria de entrevistá-lo. Sua voz, porém, não parece chegar a Haven, que sentencia: "se ela quiser uma cópia dessa música, ela poderá comprar uma quando for lançada. Por favor, peça para ela sair". O reproche à intrusa busca reestabelecer a "fronteira proibida" entre a comercialização e a produção da música

"autofabricada", do próprio disco e não o resultado de relações de produção que existem para criar e sustentar tal predominância. Dando continuidade à análise de Adorno, Wolfgang Fritz Haug descobriu uma afinidade entre o embelezamento das vozes de estrelas da música pelos trustes da indústria fonográfica norte-americana e a prática da adulteração das etiquetas de vinhos na Alemanha, adivinhando nas duas atividades a "semelhança entre a apresentação que estimula as vendas e a falsificação da mercadoria." in: Crítica da Estética da Mercadoria. p. 39.

${ }^{40}$ O termo "mixagem inaudível" aqui é uma analogia ao conceito de "decupagem transparente", com o qual se busca definir um "sistema cuidadosamente elaborado, de repertório lentamente sedimentado na evolução histórica, de modo a resultar num aparato de procedimentos 
industrializada que ela acabou de ultrapassar. Simbolicamente, o personagem também exprime, com esta fala, o seu ressentimento em relação ao narrador, que ao introduzir um ponto de vista em cena, rompeu o "fascínio acusmático" de sua música.

De fato, a entrada da voz de Opal no "agregado sonoro" desmonta a mixagem "ilusória" que o organizava. Em poucos segundos, os meios de produção e captação do som (a voz, questões de audibilidade, o microfone, fones de ouvido, etc.) são ressaltados e a harmonia entre as fontes se desfaz com a sobreposição de fontes. As próprias divisões do espaço cênico são agora sublinhadas como "zonas de incomunicabilidade": Opal fala a Haven sem ser ouvida por ele, Lady Pearl fala a Bud, que presta atenção nas ordens de Haven, que por sua vez fala ao engenheiro de som, enquanto os músicos cochicham entre si. A trajetória percorrida pela narração entre o começo e o desenvolvimento da cena tem, portanto, o objetivo de problematizar o próprio "ponto de audição" do espectador, o que ela realiza por meio de dois passos, por assim dizer, "didáticos": o estabelecimento de uma situação "naturalizada" e familiar (a mixagem "inaudível" que caracteriza seu início) e sua ruptura por meio de procedimentos de distanciamento. Este trabalho que visa a expor a "situação do espectador" por meio do "estranhamento" de suas mediações (instrumentos técnicos, mixagem, diretor, etc.) não é outro senão o que caracteriza a encenação épica.

O épico nesta cena, assim como no restante do filme, resulta de esforços concretos da equipe de filmagem no sentido de se apropriar das técnicas disponíveis para melhorá-las, adequando-as à expressão que visavam. Mais uma vez, os créditos expostos na tela assumem uma função autorreferencial, pois, no momento em que a mixagem se fragmenta, vemos exibida uma "legenda" ("som/Jim Webb/Chris Mclaughlin/sistema de som/Lion's Gate 8 track sound") que identifica o trabalho desenvolvido por Robert Altman na tempo torná-la invisível". XAVIER, Ismail. O Discurso Cinematográfico. p. 32. 
Lion's Gate, sua produtora independente, em parceria com Jim Webb. Uma pequena digressão sobre este trabalho agora nos poupará de explicações alongadas adiante, além de nos trazer conhecimentos necessários a uma fruição estética mais rica da trilha sonora em Nashville. Passemos a ela.

Antes do desenvolvimento do sistema em oito canais da Lion's Gate, as fontes sonoras na vasta maioria dos filmes hollywoodianos eram captadas por um único microfone central (boom) e mixadas na mesma faixa de um gravador rudimentar. Isto trazia consequências tanto para a composição da banda sonora, que tinha de ser planejada cuidadosamente de modo que as fontes não se sobrepusessem, quanto para a encenação, que ficava restrita à "ancoragem dramática" criada pelo boom. Em poucas palavras, a improvisação, a simultaneidade de diálogos e a fragmentação da unidade dramática da cena estavam tecnicamente excluídas do campo de possibilidades. Desde fins da década de 1960, Altman vinha, sem muito sucesso, testando formas de construir uma trilha sonora mais densa que contivesse fontes múltiplas captadas diretamente. Em Nashville seus experimentos deram um salto qualitativo com o emprego generalizado de uma técnica desenvolvida em California Split (1974), com o auxílio de Jim Webb, um engenheiro de som que trouxe para a Lion's Gate conhecimentos adquiridos na filmagem de espetáculos e documentários musicais. Distribuindo um microfone de rádio para cada fonte de som, Webb dispensava o uso do boom, captava as fontes separadamente e aumentava a liberdade de movimentação dos atores no set. As restrições à mixagem de fontes múltiplas foram abordadas com o emprego de dois gravadores de oito canais, tomados do repertório técnico da indústria fonográfica; cada gravador permitia a captação, separadamente, de sete fontes de som diferentes (o oitavo canal era usado na mixagem). Com isso, ficava liberada a improvisação dos atores, pois eventuais "erros" não contaminavam o conjunto de fontes, podendo ser alterados com a intervenção no canal que the correspondia; além disso, eram multiplicadas as possibilidades criativas da mixagem, com a transformação de volume, nitidez e colocação de cada fonte em princípios de composição. Ao solucionar dificuldades expressivas por meio da 
importação de uma técnica utilizada para produzir música enlatada, Altman e seus colaboradores demonstravam sua capacidade de refuncionalizar conhecimentos, transportando-os entre setores distintos das indústrias culturais. ${ }^{41}$

Portanto, não é exagerado sublinhar que a forma épica na cena em questão, e no filme como um todo, se assenta sobre intervenções práticas do diretor e de sua equipe em limitações expressivas do aparato técnico-industrial do cinema. Tampouco será "descabido" ver um sentido político nestas intervenções práticas, aferível quando se tem em conta que, ao elevar sua equipe de trabalho da condição de simples usuária para criadora e transformadora do aparato industrial, a técnica criada por Altman e seus colaboradores ajudou a "promover a socialização [de alguns] meios de produção intelectual". Neste sentido preciso, pode-se dizer que o processo de elaboração dessa técnica contribuiu para que os trabalhadores vislumbrassem "caminhos para [se] organizar [...] no próprio processo produtivo". Além disso, é possível entrever, para além dos objetivos imediatos que motivaram sua elaboração, "propostas para a refuncionalização"42 do cinema que, liberado do roteiro rígido e das marcações cênicas ditadas pelo boom, deixava de ser uma "estrutura de contenção" para tornar-se um locus onde trabalhadores artísticos podem experimentar novas formas de produzir.

Terminada essa digressão necessária à continuidade da análise, voltemos à "leitura cerrada" do filme, onde deixamos Opal no momento em que era expulsa da cena. A sua saída é acompanhada pelo "olhar narrador", que observará as reações da personagem em um segundo estúdio de gravação. Neste novo espaço, há também um número musical em andamento, porém com uma mixagem de som distinta da anterior: em vez de uma

\footnotetext{
${ }^{41}$ Essa breve explicação da "história" da técnica é um resumo de informações obtidas a partir de relatos sobre a captação e mixagem de som em Nashville (STUART, Jan. The Nashville Chronicles. p. 142 - 147) e de entrevistas com Altman (STERRITT, David. Robert Altman: interviews, em diferentes entrevistas) e Webb (LoBRUTTO, Vincent. Sound-on-Film: interviews with creators of film sound. p.69-82).

${ }^{42}$ BENJAMIN, Walter. O autor como produtor. in: Magia e Técnica, Arte e Política. p. 136.
} 
hierarquização harmônica, ruídos e diálogos se "esbarram" com "Do you believe in Jesus?", a canção que está sendo gravada. Os créditos continuam desempenhando uma função autorreferencial: quando a porta do estúdio é aberta, revelando engenheiros de som em primeiro plano, informações sobre trabalhos técnicos ("mixagem e edição de som/ assistente e diretor de gravação") são sobrepostas à imagem. Bud, o filho de Haven, funciona como "narrador/mestre de cerimônias", guiando-nos, junto com Opal, pelo cenário: "Aqui é o estúdio B; eu acho que eles estão gravando um número gospel". Quanto a Opal, ela agora funciona como um ponto de referência interno do espectador: assim como nossa perspectiva visual se aproxima de seu olhar situado no espaço cênico, nossa recepção da mixagem de som praticamente reproduz o seu ponto de audição. Bud e Opal sentam-se em uma posição intermediária, de frente para o número musical (que está sendo executado atrás de uma tela de vidro) e de costas para os técnicos que dirigem e manipulam os sons captados. Diferentemente da cena anterior, em que a câmera fixada sobre seu eixo vertical fazia movimentos panorâmicos, o "olhar narrador" aqui se movimenta; posicionando-se ora atrás de Opal, vendo e ouvindo exatamente o mesmo que ela, ora a seu lado, "analisando" as observações que ela faz, o foco narrativo finalmente abandona qualquer ancoragem interna para se aproximar da tela de vidro e enquadrar uma cantora branca no meio de um coral negro, em um movimento de zoom visual e sonoro.

A introdução de dois elementos complicadores - a mulher e o negro - indica um empenho da narração em produzir uma imagem mais completa dos antagonismos envolvidos na produção industrial da música, figurando também uma divisão sexual e racial do trabalho. O número que se está executando é um spiritual, forma musical religiosa que, historicamente, ganhou o sentido político de resistência negra à dominação branca. O mesmo pode ser dito do coral, composto por cantores negros semiprofissionais (Bud nos informa tratar-se de um coral universitário), com origens em uma igreja batista (como ficará claro em uma sequência mais adiante no filme), o que, no contexto de produção industrial mapeado até aqui, tem as seguintes conotações de 
cultura de resistência: é uma forma artística marcada por certo amadorismo em um ambiente extremamente profissionalizado; é uma prática musical coletiva em um contexto de divisão hierarquizada do trabalho; é uma música negra dirigida à adoração religiosa ocupando um ambiente dedicado à música branca que se pauta pelo valor econômico, o mais "profano" dos objetivos.

Contudo, todas estas contradições, que poderiam dar ao número o valor de "peça de resistência", são problematizadas pelo fato de que, no meio do coral, está Linnea, uma mulher branca, claramente alheia aos contextos sociais que produziram os demais cantores. A despeito de um desempenho técnico sensivelmente inferior ao do coral como um todo, a sua voz é ressaltada na mixagem, como, aliás, um dos engenheiros de som "deixa escapar" ao dizer "Me dá um pouco mais de Linnea aqui". Além disso, sua imagem é valorizada pela disposição cênica, ocupando uma posição central no campo de visão dos observadores internos e do "olhar narrador". Em outras palavras, a cantora branca e despreparada é uma espécie de lead singer do coral negro semiprofissional, o que é uma maneira de recuperar o star system que organiza os trabalhos no estúdio A, porém com uma "sobreposição": a hierarquização aqui é também guiada por racismo ${ }^{43}$.

É preciso ter em mente este jogo de antagonismos cruzados para se avaliar tanto os problemas políticos colocados em cena quanto o modo como são percebidos pelos observadores internos. De partida, Bud, nosso "mestre de cerimônias", dirige a atenção de Opal para a cantora no meio do coral: "Este é um coral, o coral negro da Fisk University daqui da cidade; a senhora que está cantando, a cantora gospel, é a esposa de nosso procurador". O contraste entre a atividade do coral (um trabalho, ainda que semiprofissional)

\footnotetext{
${ }^{43}$ A cena sugere, portanto, um "matiz racial" sobreposto às disputas entre direita e esquerda dentro da indústria fonográfica norte-americana, na atribulada passagem dos anos 1960 aos 1970. Essa também parece ter sido a leitura de Burton Peretti, para quem a música country, o produto de uma "indústria próspera e de grande apelo, se tornou ainda mais popular nos anos 1970", vendendo-se "como refúgio simbólico da proliferação de estilos musicais negros. O Grand Ole Opry de Nashville e os clubes em Branson, Missouri, promoviam o 'patrimônio' country e as 'tradições familiares' de uma forma que falava somente aos ouvintes brancos." in: Jazz in American Culture. p. $162-163$.
} 
e a da cantora (uma espécie de hobby inconsequente) não é percebido por Opal, que faz uma leitura distorcida do tipo de intercâmbio cultural entre os dois grupos étnicos representados. ${ }^{44}$ Enquadrado pela tela de vidro, o espetáculo é "lido" pela observadora interna a partir dos preconceitos visuais do star system, o que resulta numa analogia entre a interação racial que ele promove e o trabalho "civilizatório" das missões brancas na África negra:

"Meu Deus! Ela é missionária? Eu estava fazendo um documentário no Quênia e tinha uma mulher maravilhosa, uma missionária, e é por isso que eu perguntei se ela era missionária também. Ela era sensacional; convertia kikuyus às dúzias. Ela estava tentando converter massais, mas é claro que eles eram um caso perdido, com sua própria religião e tudo mais".

$\mathrm{Na}$ medida em que não concebe a possibilidade de que, nesta interação, a "função pedagógica" do trabalho seja conduzida pelos negros e não pela cantora das "horas vagas", o comentário é evidentemente racista. Embora seja impossível determinar o quanto do racismo expresso pela personagem é atribuível a uma visão de mundo enquadrada pelo star system, o fato é que a posição que ela ocupa, tanto ideológica (documentarista produzindo uma interpretação da indústria fonográfica) quanto fisicamente (espectadora de um número musical montado segundo as regras desta indústria), continua a fazer "estragos" na sua avaliação do quadro sociocultural diante de seus olhos. A observação seguinte não apenas dá prosseguimento ao elogio à dominação imperialista da África, mas também atrela, indiretamente, um sinal positivo no processo de absorção industrial e consequente apaziguamento da música negra de resistência:

Opal: (Com um tom maravilhado) Veja só isso! Este ritmo é fantástico! É engraçado, mas dá para perceber; ele veio nos genes ao longo de eras e eras e centenas de anos, mas ainda está lá! Quero dizer, é só remover aquelas túnicas e voltamos à

\footnotetext{
${ }^{44}$ Para se apreciar o significado político deste contraste, não custa lembrar o que nos ensinaram Adorno e Horkheimer sobre a relação entre hobby e trabalho: "O hobby consiste na repetição do trabalho artesanal, do qual - no quadro das relações de propriedade - está necessariamente excluído há muito tempo. [O sujeito que tem um hobby] se compraz nele porque a liberdade de
} 
África mais negra! Parece que eu consigo ver seus corpos negros, frenéticos, dançando à batida do... (Com um tom de curiosidade) É assim que eles fazem na igreja?

Bud: Depende da igreja que você frequenta.

Fazendo abstração dos conteúdos imediatos da cena, sobram as suas formas básicas: a divisão do espaço em três partes distintas, com uma plateia posicionada entre um espetáculo e sua direção. Este modo de distribuir os elementos cênicos expõe o próprio dispositivo cinematográfico: o número musical, emoldurado pelas quatro linhas da janela de vidro em formato widescreen, evoca a forma visual que o cinema popularizou nas duas décadas anteriores; no espaço intermediário onde se encontram Opal e Bud, reconstróise a situação do espectador; a mesa de edição, onde trabalham os técnicos de som, às costas dos espectadores, representa um espaço onde se dá a manipulação do material captado pelo aparato técnico ${ }^{45}$. Deste modo, a encenação se esmera, mais uma vez, na tarefa épica e autorreferencial de expor as limitações físicas, técnicas e ideológicas do olhar. Confinada a uma posição que mimetiza a "cadeira de cinema", seduzida por um espetáculo formatado à semelhança dos filmes, Opal traz à tona um repertório analítico em que se encaixam uma experiência estética (o modo de ver sedimentado pela fruição repetida de filmes) com uma experiência política (um "olhar branco" do dominador sobre o negro dominado). O interesse da cena está em demonstrar esta correspondência entre o ponto de vista físico e o ponto de vista ideológico da personagem, funcionando como um alerta para que o espectador percorra as imagens e a trilha sonora com olhar e ouvido sempre móveis e curiosos, evitando reproduzir a rigidez e, portanto, as limitações de Opal ${ }^{46}$.

fazer o que para ele é supérfluo confirma seu poder de dispor sobre aqueles que têm que realizar tais trabalhos para viver." in: Dialética do Esclarecimento. p. 76.

${ }^{45} \mathrm{Na}$ medida em que apresenta "uma experiência que, em sua estrutura, reproduz a geometria do espetáculo" cinematográfico (XAVIER, Ismail. O lugar do crime: a noção clássica de representação e a teoria do espetáculo, de Griffith a Hitchcock. in: O Olhar e a Cena. p. 72), esta cena de Nashville oferece uma "metáfora do espectador" análoga àquela que se tornou um clássico na cinematografia norte-americana: Janela Indiscreta (Alfred Hitchcock, 1954).

${ }^{46}$ Neste sentido, a encenação cumpre a tarefa crítica de produzir uma "reflexão sobre o aparelho de base", fazendo o reconhecimento de seu "inconsciente" (as diversas mediações técnicas do olhar e do ouvir na cena), sem, no entanto, se dobrar à visão fatalista de que não é possível 
A "lição" tirada a partir da representação cênica da "atividade do espectador", a saber, que não existe "olhar isento" sobre qualquer fato cultural e que a rigidez da ancoragem física de um ponto de vista pode ser um indício de posicionamentos ideológicos ossificados, deve ser testada logo em seguida, quando o foco narrativo é novamente dirigido ao estúdio A. Agora, tal lição servirá para que o espectador efetue o desmanche ideológico da mirada que Haven lança sobre a história norte-americana em "200 Years", sua canção de trabalho. A sequência abre com os backing vocals em um plano fechado, enquanto, na trilha, a voz de Haven voltou a dominar. Irritado, o cantor interrompe a gravação para fazer um trocadilho sarcástico a respeito do nome do pianista ${ }^{47}$ que parece cansado e desmotivado, o que sugere não ter sido esta a primeira repreensão que leva do star no decorrer do dia. A próxima parada se deve, novamente, a um acorde dissonante do piano, ao que Haven reage com irritação: "Vá para o inferno! Bob, como é mesmo que você disse que o pianista se chama?... Pois quando eu pedir Pig é porque eu quero Pig. Então, vê se você me consegue Pig e aí nós poderemos gravar esta música." ${ }^{48}$

Tendo repreendido o diretor por não contratar o músico de sua preferência, Haven sai de dentro da cabine "pisando duro", se aproxima do pianista e o exclui do processo produtivo, dizendo: "Vai cortar esse cabelo! Seu lugar não é em Nashville". O enquadramento dos dois personagens no mesmo plano (Frog sentado ao piano e Haven, de pé, por trás dele) permite identificar a assimetria de suas posições sociais a partir de uma série de oposições: com cabelo comprido, camisa aberta ao peito, corrente no pescoço e

escapar à ideologia que inscreveu sua dominação no próprio aparato técnico do cinema. Embora a posição de Opal na cena canalize seu olhar para o centro da tela onde se encontra a cantora branca, nenhuma limitação técnica impede que ela percorra o quadro inteiro e o próprio espaço ao seu redor. Portanto, o filme atualiza as preocupações teóricas de Jean-Louis Baudry (in: Cinema: efeitos ideológicos produzidos pelo aparelho de base. in: Ismail Xavier (org). $A$ Experiência do Cinema. p. 399), mas faz um ajuste necessário a suas conclusões: os efeitos ideológicos em questão não são produzidos pelo aparelho em si, mas por determinados modos de usá-lo.

47 "Bob, qual é o nome do pianista?", pergunta Haven ao diretor, ao que este responde: "É Frog" (frog, em inglês, quer dizer "sapo") e Haven arremata: "Sapo! Pois ele toca como um sapo". 
óculos escuros, Frog reproduz alguns traços associáveis à imagem de uma juventude "antiestablishment", típica da "cultura rock" dos anos 1960; já o figurino de "cowboy patriótico" de Haven (roupa de vaqueiro, em tecido branco bordado, finalizado por uma peruca bem penteada e posta sobre um par de costeletas) "transpira" a oficialidade patriarcal country, o que, numa cidade dedicada a esses negócios, tem necessariamente um sentido conservador. Estes contrastes entre as imagens dos personagens sugerem que o sentido do gesto de demitir não se esgota na mera questão técnica (o fato de Frog não ser tão preparado quanto $\mathrm{Pig}$ ), mas ganha o significado político de tentativa de eliminar um signo cultural de transgressão ("Vai cortar esse cabelo!") não apenas do estúdio, mas do conjunto de relações de produção constituído na cidade ("O seu lugar não é em Nashville"). Por outro lado, ao mostrar que a exclusão social e cultural de Frog se assenta sobre uma premissa material - a existência de uma relação de produção em que o empregador pode desfazer 0 contrato de trabalho sem nenhuma restrição aparente - a cena dá uma nova inteligibilidade à série de imagens contrastantes; mediadas pela ação de demitir, as dicotomias "sentado/em pé", "jovem/velho", "figura transgressora/figura paterna", "rock/country", etc., deixam de figurar simples oposições no plano da imagem para ganhar o valor expositivo de formas variadas de manifestação de um mesmo conflito de interesses de classe, aquele pressuposto na relação desigual entre contratado e contratante ${ }^{49}$.

\footnotetext{
${ }^{48}$ Pig ("porco" em inglês) é o apelido de um músico muito requisitado em Nashville à época das filmagens, segundo o próprio Altman nos comentários da versão em DVD do filme. A intenção sarcástica ("quando eu pedir porco, não me dê sapo") não carece de explicações.

49 Sobre o modo como estes contrastes têm sido interpretados, vale lembrar que, segundo Thomas Frank, estudos contemporâneos da "cultura jovem" comercial produzida nos anos 1960 não têm conseguido aferir seu valor para a constituição de formas simbólicas de resistência política, o que talvez possa ser atribuído a uma incapacidade de pensar os conceitos de transgressão e ordem dentro de relações de produção contraditórias, que tais estudos tendem a opor em categorias abstratas e rígidas. "Pressupondo que significantes da cultura jovem são apropriados, produzidos e até mesmo inventados pela indústria do entretenimento, estudiosos recentes argumentam que a resistência surge do consumo destes significantes, pelos jovens, de formas divergentes ou contrárias às intenções opressivas de seus fabricantes. A forma que as culturas jovens pré-fabricadas recebem de seus produtores não é vista como um fator importante, pois tais culturas são rapidamente decompostas e remontadas por jovens alienados em subculturas novas e surpreendentes. Como ocorre nas análises da contracultura, é a transgressão por si mesma, a interminável corrida para violar regras, que constitui, neste tipo de
} 
O esmero com que Haven cuida de sua autoimagem, certificando-se de estar sempre "caracterizado" como "Haven Hamilton", astro da música, mesmo no ambiente fechado do estúdio, dá a medida da seriedade com que encara o esforço cotidiano necessário à construção de uma "autenticidade uniforme" para o country business. Segundo Richard Peterson, este esforço consciente de fabricação de uma imagem country teve como ponto de partida a figura do hillbilly (caipira), comercialmente formatada à maneira das "figuras tipificadas do vaudeville e do teatro popular." ${ }^{50}$ No final dos anos 1920 , as apresentações de antigos tocadores de fiddle (espécie de violino caipira), provenientes de confins do país, alguns dos quais nascidos durante a Guerra Civil, traziam, para uma audiência confrontada com mercadorias culturais massificadas, uma imagem de autenticidade,

"uma lembrança nostálgica de bailes comunitários, shows promocionais de medicamentos, cantores de rua, tudo empacotado com respeito e num formato acelerado, bem ao gosto da 'maravilha eletrônica da época', o rádio."

Peterson lembra ainda que, de um modo geral, os músicos que tentavam a sorte em programas de rádio tais como o Grand Ole Opry, no final dos anos 1920, raramente vinham do campo; ou seja, o termo hillbilly era menos uma descrição de sua origem de classe do que uma imagem fabricada de modo a autenticar a experiência social prometida por sua música.

Se as ressonâncias do hillbilly na imagem comercial de Haven evocam a segurança de antigas relações patriarcais, as alusões à figura do cowboy em seu figurino apontam para a imagem moderna do empreendedor country, o homem da "livre iniciativa", viril e agressivo como o

análise, a chave para a resistência." in: The Conquest of Cool. p. 17. Neste sentido, Nashville talvez ensine algo à crítica, demonstrando que relações de produção marcadas por contradições internas são necessariamente conflituosas e potencialmente geradoras de algum tipo de resistência, de modo que a presença da "cultura rock" na cidade configura uma forma de dissidência não porque ela "consome", de maneira inovadora, "significantes" produzidos pelo establishment, mas porque é produzida como uma "cultura subalterna" dentro de um quadro de relações de produção dominadas pela oficialidade country.

${ }_{51}^{5}$ PETERSON, Richard A. Creating Country Music. p. 69.

${ }^{51}$ Ibid., p.70. 
vaqueiro solitário. Remontando aos romances baratos de meados do século XIX e aos espetáculos itinerantes estrelados por William Cody (artisticamente conhecido como "Buffalo Bill"), a imagem do cowboy na cultura popular norteamericana antecede o surgimento da indústria country em praticamente cem anos, tendo sido associada à música popular apenas em 1910, por meio de uma antologia intitulada Cowboy Songs and Other Frontier Ballads.

"Em sua introdução a essa antologia, John A. Lomax já adiantava a descrição romantizada dos modos do cowboy: 'Eles amavam vagar pelo espaço; eles amavam a liberdade; eles eram pioneiros por instinto; um impulso desviava seus rostos do leste e punha um gosto pela viagem no seu sangue, enviando-os sempre, sempre, na direção do oeste.",52

Com a produção de westerns musicais a partir da década de 1930, muitos cantores adotaram a indumentária do cowboy de modo a fazer avançar suas carreiras. A moda era tão difundida que

"praticamente todos os artistas country, tanto homens quanto mulheres, passaram a adotar trajes western ao longo dos anos 1940, tentando projetar, de diversas maneiras, uma imagem pública de cowboy em vez de hillbilly."53

Porém, foi a fusão da imagem do cowboy com os elementos musicais da tradição caipira que deram ao country uma forma estética necessária à sua ascensão comercial. Bill Malone vê, na exploração da imagem do cowboy entre as décadas de 1930 e 1940, o reflexo de um amplo movimento na cultura norte-americana:

"De Nova lorque à Califórnia, indivíduos respondiam bem ao mito do oeste, o que levou ao aparecimento de cowboys cantores mesmo nos lugares mais inesperados. A palavra 'Western' se tornou um termo rival e muitas vezes preferível a hillbilly como uma designação apropriada para a música country. Evidentemente, é fácil entender por que western tinha um apelo maior em relação à palavra hillbilly. Western, especificamente, sugeria uma música que havia sido desenvolvida por cowboys nas planícies do Texas; de uma

\footnotetext{
${ }^{52}$ PETERSON, Richard A. Creating Country Music. p. 82

${ }^{53}$ Ibid., p. 91
} 
maneira mais geral, o termo sugeria um contexto de relações livre, aberto e expansível. Resumindo, era uma palavra que se amoldava ao autoconceito norte-americano." ${ }^{54}$

Quando compõe uma promessa estética que combina a coletividade patriarcal da tradição hillbilly com a rebeldia individual do cowboy, Haven visa o objetivo sugerido no texto de Bill Malone: oferecer um espelhamento cultural para os impulsos conservadores de um posicionamento político marcado pela defesa do liberalismo econômico e sua obsessão por um "contexto de relações livre, aberto e expansível". Embora seu controle com "punho de ferro" sobre todos os aspectos da produção o caracterize como o administrador de uma estrutura de trabalho totalitária, a combinação destas duas figuras popularizadas pela cultura de massas projeta uma imagem pastoril e nostálgica sobre Haven, evocando, ao mesmo tempo, os aventureiros desbravadores do oeste e os "pais" fundadores da nação norte-americana. ${ }^{55}$

Este apelo à imagem da "América dos fundadores" parece ser, entre outras coisas, uma tentativa de encobrir o fardo de uma rotina de trabalho denunciado pela expressão cansada, mecanizada e desmoralizada do pianista. Tal contradição entre aparência e realidade da produção cultural na indústria country tem desdobramentos no próprio "elogio ao trabalho" implícito na canção de Haven:

"Tem sido um trabalho duro, mas cada vez que nos encontrarmos em dificuldade,

pensemos no que nossos filhos enfrentarão em 2076.

Cabe a nós abrir o caminho com nosso sangue, suor e lágrimas.

\footnotetext{
${ }^{54}$ MALONE, Bill C. Country Music U. S. A. p. $151-152$.

$55 \mathrm{Na}$ medida em que encena o trabalho de produzir música visando a desmascarar a permanência do totalitarismo (o cantor que controla de perto todos os aspectos da produção) no setor produtivo mais privilegiado nas democracias ocidentais, esta cena de Nashville antecipa Ensaio de Orquestra (1979), filme em que Fellini esmiuçaria o assunto mais tarde. Tanto Ensaio de Orquestra quanto a excelente análise que Luiz Renato Martins produziu de seus temas (Entre a contemplação e o choque. in: Conflito e Interpretação em Fellini. p. 87 - 116) serviram de guia à interpretação que fizemos da "sequência dos estúdios" em Nashville.
} 
Oh, devemos estar fazendo a coisa certa para durar duzentos

anos!,56

Nestes versos, a evocação de antigas ideologias que fazem da mortificação do corpo um valor moral serve de ataque antecipado a qualquer voz discordante; porém, por uma questão de lógica discursiva, a positivação do trabalho sacrificante pressupõe um reconhecimento, ainda que silencioso, de que se trata de uma atividade que renuncia ao gozo. Se um dos modos "de operação da ideologia é o uso do silêncio" ${ }^{\text {"2 }}$, então o fato de a canção indiretamente reconhecer a existência do sacrifício significa um pequeno abalo em seu efeito ideológico. ${ }^{58} \mathrm{O}$ intuito destes versos, que implicitamente renunciam ao trabalho como atividade lúdica, parece ser o de projetar Haven como um representante moderno dos princípios "franklinianos" de promoção da comunidade por meio do esforço empreendedor, com os quais o imaginário norte-americano tem "adoçado" a exploração capitalista desde os primeiros passos da colonização ${ }^{59}$.

Porém, se a atribulada economia dos anos 1970 não pode ser equiparada aos momentos "gloriosos" do capitalismo em expansão, tampouco será justa uma analogia entre Haven e os founding fathers. $\mathrm{O}$ que

\footnotetext{
56 "It's been hard work but every time we get into a fix/ let's think of what our children face in 2076./ It's up to us to pave the way with our blood and sweat and tears./ Oh, we must be doing something right to last two hundred years!"

${ }^{57}$ Uma das maneiras "de operação da ideologia é o uso do silêncio. Um imaginário social se parece com uma frase onde nem tudo é dito, nem pode ser dito, porque, se tudo fosse dito, a frase perderia a coerência, tornar-se-ia incoerente e contraditória e ninguém acreditaria nela. A coerência e a unidade do imaginário social ou ideologia vêm, portanto, do que é silenciado." CHAUÍ, Marilena. Convite à Filosofia. p. 175.

${ }^{58}$ Neste sentido, a própria estrutura objetiva do discurso verbal impede que uma canção como "200 Years" se converta numa "narrativa fechada" da dominação. Como nos ensina Alan Sinfield, uma peça ideológica como "200 Years" dá provas de que "a ordem social não consegue deixar de produzir falhas por meio das quais seus critérios de plausibilidade se desarranjam e caem em contradição" (p. 45). Se a ideologia dominante não pode abarcar tudo, se ela não consegue harmonizar todas as suas contradições internas, ela deixa entrever os espaços entre a ideologia e a prática (p. 46). Além disso, se toda história que é contada precisa negociar suas condições de plausibilidade, tem-se que toda história é passível de ser submetida a uma crítica política. Toda afirmação é a negação de tudo o que ela omite (p. 47). SINFIELD, Alan. Cultural materialism, Othello, and the politics of plausibility. in: Faultlines.

${ }^{59}$ WEBER, Max. A Ética Protestante e o "Espírito" do Capitalismo", sobretudo o capítulo 2 da parte I ("O 'espírito' do capitalismo") e o capítulo 2 da parte II ("Ascese e capitalismo").
} 
torna a comparação inadequada é uma dupla degradação da base produtiva entre um momento histórico e outro: por um lado, a generalização da incerteza (o contrato de Frog é por obra e pôde ser terminado com uma simples ordem para "cortar o cabelo") e de condições precárias de realização esvazia a experiência subjetiva do trabalho, tornando inviável a sua conversão em modelo para a prática ética; por outro lado, a redução do self-made man, o sujeito da "livre-iniciativa", a uma celebridade autoritária e interesseira, mais ocupada com seu sucesso pessoal do que em promover o pleno emprego da comunidade, revela que tais imagens (self-made man, frontiersman, founding father) nunca passaram de ideologias justificadoras das classes dominantes ${ }^{60}$.

Em certo sentido, é a história desta dupla degradação da relação do sujeito com a sociabilidade, pela mediação do trabalho, que dá coerência a "200 Years", embora aqui ela apareça com sinal trocado, como uma celebração da jornada bicentenária do expansionismo norte-americano na forma de crônica de um "caso de sucesso". Esses duzentos anos são resumidos na primeira estrofe:

"Os ancestrais de minha mãe vieram de navio e lutaram em Bunker Hill.

\footnotetext{
${ }^{60}$ Neste sentido, é possível ver na caracterização de Haven uma crítica a toda uma classe de cantores/empresários que atuavam no country business da época. Os esforços que o personagem aplica na criação de um determinado tipo de imagem pública, a partir da escolha de temas e figurino, suscitaram na imprensa associações com a figura factual de Hank Snow: "'Talvez [o filme] tenha atingido diretamente algumas pessoas. Não há dúvida de que os personagens principais são [versões de] Loretta Lynn e Hank Snow. O filme exagera um pouco a respeito do que eles fazem, mas os personagens principais são baseados nos dois." SMITH, Carl. apud in: STUART, Jan. The Nashville Chronicles. p. 294. Já o seu modo de monopolizar várias das funções produtivas disponíveis na cidade (cantor, produtor musical, relações públicas da indústria, patrocinador de equipes automobilísticas) aproxima Haven de Roy Acuff, uma figura cuja biografia se mistura à própria ascensão da indústria country em Nashville. Estrela do programa de rádio Grand Ole Opry, conhecido como "the King of Country Music", Roy Acuff foi um dos primeiros músicos country a tornar-se também empresário quando, em outubro de 1942, abriu, junto com o compositor e pianista Fred Rose, a editora de música Acuff-Rose Publications. Assim como o Haven da Nashville ficcional, a carreira empresarial de Acuff e o papel de Nashville na indústria da música estão diretamente ligados, pois a empresa aberta pelo músico do rádio ajudou a encaminhar a centralização da produção country na cidade. in: PECKNOLD, Diane. The Selling Sound. p. 57.
} 
Meu pai perdeu uma perna na França, ainda guardo suas medalhas.

Meu irmão serviu com Patton e eu lutei em Argel.

Ó, nós temos de estar fazendo a coisa certa para durarmos duzentos anos! $!^{61}$

Note-se que, embora Haven e seus ancestrais sejam os sujeitos gramaticais destes primeiros versos, a sua linhagem funciona como a representante de um "sujeito oculto", o efetivo vencedor de cada uma das batalhas listadas: o capital norte-americano em expansão, desde o momento em que removeu as barreiras impostas pela Grã Bretanha (figurado na Batalha de Bunker Hill, passagem importante do movimento de independência) até as guerras imperialistas do século XX (marcadas com as referências à França, a Patton e à Argélia). A variação pronominal entre os três primeiros versos e o estribilho, em que se passa gradativamente da singularidade ("minha mãe", "meu pai", "meu irmão", "eu”) à universalidade ("nós"), para fazer um balanço positivo da dominação ("devemos estar fazendo a coisa certa..."), revela o processo ideológico de constituição de um "sujeito autoritário". No movimento que vai do particular ao geral, adivinha-se o "sequestro" que o personagem faz dos acontecimentos históricos, dando a eles o sentido privado de "passagens do anedotário familiar", para então devolvê-los à coletividade na forma de uma "leitura oficial" da história norte-americana. Ou seja, estes primeiros versos dão uma forma simbólica ao desejo que as classes dominantes têm de transformar a sua visão particular da História em "última palavra", em "balanço" com validade geral e indiscutível. Mais do que isso, a visão positivada dos duzentos anos de batalhas e vitórias sucessivas visa a transformar a dominação exercida por essas classes em algo bom, moral ("devemos estar fazendo a coisa certa") e, a julgar pelo tom eufórico de Haven, desejável. Os derrotados em cada passo, os mortos em vão, aqueles de quem não se guardaram "medalhas", permanecem

\footnotetext{
61 "My mother's people came by ship and fought at Bunker Hill./ My daddy lost a leg in France, I have his medals still/ My brother served with Patton, I saw action in Algiers./ Oh, we must be doing something right to last two hundred years."
} 
ausentes da superfície discursiva da canção, apagados de sua letra extremamente simples e direta ${ }^{62}$.

O modo como Haven justifica a dominação, transformando sua persistência no tempo em prova de valor ético ("se tem durado é porque é correta"), ecoa as ideologias estéticas utilizadas pela propaganda da indústria country, na legitimação cultural de seus negócios. Assim como Haven pede sacrifícios para a construção de mais um século norteamericano (até 2076), a oficialidade da indústria country, por meio de associações patronais como a CMA (Country Music Association), encorajava fãs e músicos a realizar trabalho promocional não pago (formação de fãs-clubes, lobby político em favor da indústria, cartas exigindo programação country nas rádios e cobertura na imprensa, etc.) que contribuísse para a valorização cultural de sua música a partir do seguinte "argumento": "se ela vende muito é porque é boa"63. Tanto em um caso (o sacrifício em prol do capital expansionista) quanto no outro (o trabalho não remunerado para uma indústria que vive de explorar o trabalho), a dominação busca justificar-se como uma ação necessária à promoção de um bem coletivo maior.

\footnotetext{
62 Esta simplicidade da letra, sua falta de elaboração e, de certo modo, sua ingenuidade na exposição de um ponto de vista de classe devem ser, em larga medida, atribuídas ao fato de ter sido composta por Henry Gibson, o ator que interpreta Haven, mas que não tinha o treinamento necessário à produção de uma letra segundo os ditames estilísticos da indústria country. Para chegar a efeitos parecidos com o alcançado em "200 Years", Altman encorajou os atores interpretando cantores a compor suas próprias canções. Ao trabalhar desta forma, Altman dava pequenas contribuições, conscientes ou não, para superar a fragmentação industrial do artista em saberes parciais: na medida em que os atores se tornavam também compositores, o trabalho de construção do personagem podia estender-se até a elaboração de partes do texto. $\mathrm{Na}$ hipótese mais modesta, isso significa uma distribuição, ainda que localizada, de conhecimentos do processo de produção do filme.

63 Estranhamente, a "reação à direita" (backlash), que se sentia tão bem representada pela oficialidade country e sua versão particular de consumismo, atacava Hollywood por seu "liberalismo" e "materialismo" excessivos. Esta aparente contradição só existia no plano do discurso, pois o ataque à indústria do cinema, sobre a qual pesavam narrativas de conspirações de esquerda e de esnobismo em relação à população distante dos grandes centros de produção cultural, dava à "reação à direita" um "vocabulário político" com o qual definir uma plataforma. No plano da práxis material, entretanto, a "reação à direita" e a cultura comercial no seu sentido mais amplo se complementavam: "o conservadorismo oferece a seus seguidores um universo paralelo, preenchido com as mesmas mercadorias pseudoespirituais encontradas no mainstream: autenticidade, rebelião, a nobreza do martírio e até mesmo a individualidade. Mas a similaridade mais importante entre a reação à direita e a cultura comercial mainstream é o fato
} 
$\mathrm{Na}$ segunda estrofe, Haven projeta sobre sua descendência a "proteção divina" que "presidiu" as vitórias de sua linhagem: "Rezo para meus filhos não irem para a guerra, mas se tiverem de ir, irão./ Compartilho a divisa de nosso país e em Deus ponho minha confiança." ${ }^{\circ 4}$ A terceira estrofe interrompe a crônica das guerras imperialistas e fala de catástrofes domésticas, produzidas pela interação das condições climáticas no Sul (as secas conhecidas como "dust bowl droughts") e o acirramento das contradições internas do processo capitalista (a depressão e a crise de superprodução):

\author{
"Passei por duas depressões e sete 'dust bowl droughts' \\ Enchentes, gafanhotos e tornados, mas não tenho a menor \\ dúvida. \\ Todos fazemos a História, a velha bandeira nos mostra \\ O quanto caminhamos até aqui e o quanto nos resta a \\ caminhar. ${ }^{, 65}$
}

A quarta e última estrofe é aquela que citamos acima, que projeta a trajetória de trabalho duro e do sacrifício humano nos cem anos seguintes, até 2076.

O salto temporal entre a terceira e a quarta estrofes produz uma frustração das expectativas construídas ao longo das duas primeiras. Ora, se a listagem das batalhas chegou à Segunda Guerra Mundial (Argel), era de se esperar que no prosseguimento houvesse uma menção da Guerra do Vietnã, em curso no momento de produção da canção; o mesmo vale para os eventos da terceira estrofe, que trazem à memória a Grande Depressão,

de que ambas se recusam a pensar o capitalismo criticamente." FRANK, Thomas. What's the Matter with Kansas? p. 242.

64 "I pray my sons won't go to war, but if they must, they must./ I share our country's motto and in God I place my trust."

65 "I've been through two depressions and seven dust-bowl droughts./ Floods, locusts and tornadoes, but I don't have any doubts./ We're all a part of history, why Old Glory waves to show/ how far we've come along till now, how far we've got to go." 
mas não a conectam com os ciclos de expansão e crise do capital nos anos 1970. Em vez de seguir sua própria lógica expositiva, a canção para, toma fôlego e dá um salto de cem anos com o qual visa a apagar os buracos em sua "narrativa que indicam tantas brechas possíveis no continuum da [sua] dominação"66.

É neste hiato entre o passado e um futuro abstrato que se localizam os problemas presentes, dos quais se ocuparam vozes na indústria fonográfica opostas ao country. Embora estas vozes tenham sido removidas da "superfície consciente" de "200 Years", elas ficaram "inscritas" no seu "inconsciente político", na forma de pressupostos lógicos não reconhecidos. ${ }^{67}$ Trata-se de "dissonâncias inaudíveis" que um ouvido crítico, orientado por uma concepção "da história como luta permanente"68, deve tentar recuperar, de modo a reconstruir o campo discursivo-ideológico de onde a canção emerge. O salto temporal que desequilibra a estrutura de expectativas criada pelas primeiras estrofes equivale a um "ato falho", a partir do qual é possível ir "pinçando", em retrospecto, os "textos negativos" silenciados por cada afirmação na letra. Por exemplo, os versos que se valem da crença na "ajuda divina" para justificar o envio dos filhos à guerra ganham o sentido de "movimentos de ataque" em uma "batalha discursiva" quando identificamos, nas suas "sombras", as vozes de outras canções populares que punham em dúvida

${ }^{66}$ GAGNEBIN, Jeanne Marie. História e Narração em Walter Benjamin. p. 100.

${ }^{67} \mathrm{O}$ conceito é de Fredric Jameson ( $O$ Inconsciente Político) e designa um substrato político recalcado em todo texto cultural, sobretudo naqueles mais degradados pela forma mercadoria (por exemplo, o filme Tubarão, que Jameson analisa em "Reificação e utopia na cultura de massa", in. As Marcas do Visível. p. 9 - 35). Na sua compulsão obsessiva para legitimar a dominação, "200 Years" procede como tantas outras obras desfiguradas pela forma-mercadoria: nega a História como luta de classes ao remover toda contradição de sua superfície aparente, mas a inscreve, porque não podem deixar de fazê-lo, em sua estrutura profunda, silenciosa. A busca pelos indícios discursivos do "inconsciente político" de "200 Years" se apoia também sobre a obra de Bakhtin, para quem o próprio signo é "uma arena onde se desenvolve a luta de classes". A ideia de que todo signo é marcado por uma "dialética interna" que "não se revela inteiramente a não ser nas épocas de crise social" parece bastante adequada para se aferir o valor de cada palavra usada em "200 Years" com referência às grandes atribulações sociais que marcaram aquele momento histórico dos EUA. BAKHTIN, Mikhail. Marxismo e Filosofia da Linguagem. p. 47 e 48.

${ }^{68}$ LÖWY, Michael. Walter Benjamin: aviso de incêndio. p. 51. 
a moralidade do assassinato em massa ${ }^{69}$. Da mesma forma, a necessidade que uma figura da ordem como Haven tem de fazer um balanço elogioso de sua dominação bicentenária fica mais clara se trouxermos à mente canções empenhadas em denunciar a "caretice" e a violência de uma sociedade patriarcal envelhecida.

Portanto, cada uma das afirmações feitas na superfície consciente de "200 Years" faz ressoar, na sua estrutura profunda, fragmentos de canções e vozes de protesto produzidas no período; ou seja, a canção reencena, simbolicamente, os embates discursivos entre conservadorismo e contestação que animaram a atribulada passagem dos anos 1960 aos 1970 nos EUA. Tal leitura ganha mais força se lembrarmos que muitas das "canções de protesto" que "200 Years" "recalca" travavam, inspiradas pelo "folk revival", uma disputa com a indústria country pela posição de herdeiros legítimos da cultura popular norte-americana, o que traz à tona o significado material deste embate entre dois setores opostos da indústria fonográfica: em jogo estava a apropriação comercial da herança cultural em comum ${ }^{70}$.

69 Observe-se, por exemplo, essa última estrofe de "With God on Our Side" (1963), de Bob Dylan: "Agora conforme vou partindo/ Cansado como o diabo/ A confusão que sinto/ nenhuma língua consegue expressar/ Palavras enchem minha cabeça/ e caem pelo chão/ Mas se Deus está do nosso lado/ Ele impedirá a próxima guerra". ("So now as I'm leavin'/ I'm weary as hell/ The confusion I'm feelin'/ Ain't no tongue can tell/ The words fill my head and fall to the floor/ If God is on our side/ He'll stop the next war"). Disponivel em: http://www.bobdylan.com/us/songs/god-our-side. Consultado em 18/07/2012.

${ }^{70}$ De fato, embora tenha a aparência de um bloco hegemônico coeso, a indústria country nunca pôde contar com uma aceitação incontestada de seu posicionamento comercial e cultural entre todos os praticantes da música identificada com a tradição popular (folk) norte-americana. Como nos ensina Diane Pecknold (The Selling Sound), as resistências iniciais à música country vieram da direita: "Os produtores de música popular comercial não estavam sozinhos em suas preocupações sobre o modo como a música caipira e as inovações tecnológicas que a produziram afetariam hierarquias e valores culturais. Os patronos do movimento de preservação folk e a classe média vitoriana que eles representavam assimilaram a música caipira comercial numa filosofia mais abrangente de um antimodernismo que militava contra as influências dos meios de comunicação de massa e da industrialização" (p. 28). Porém, durante os anos da "caça às bruxas" perpetrada pelo senador McCarthy, o folk passa a ser associado a posições políticas de esquerda, transformando-se em um movimento underground, para ressurgir apenas no final dos anos 1950, na forma de uma revitalização urbana (o folk revival), a partir do ambiente universitário (centros acadêmicos, cafés, etc.) na esteira de cursos de estudos de folclore que se espalhavam pelo país. "Ainda que os 'revivalistas' e folcloristas do início dos anos 1960 fossem animados primordialmente por sua preocupação com uma tradição popular que só em alguns pontos esbarrava na música country comercial, eles eram mais abertos a aceitar que a música 
Terminado o primeiro quadro temático, fica mais clara a forma dialética adotada pela narração. As duas sequências que o compõem observam o mesmo assunto (o processo de absorção da política pela economia via indústrias culturais), mas o fazem a partir de perspectivas diversas: na avenida, o foco recai sobre a denúncia da forma estética e do canal mercadológico assumido pela política. Nos estúdios, a mirada é invertida e a ênfase é posta sobre o sentido político de uma cultura produzida industrialmente. Se na avenida o olhar é externo à cena, contemplando o fenômeno histórico a partir de sua aparência final, no estúdio, a narração "esmiúça" o assunto, localizando o "olhar da câmera" no espaço cênico e duplicando sua mirada com a criação de pontos de observação internos. Essa reviravolta da perspectiva implica uma alternância de "modos de conhecer": se na primeira parte o conhecimento do fenômeno sócio-histórico se dá pela contemplação de sua aparência, na segunda parte é a investigação por meios fílmicos (os pontos de vista e de audição inseridos e reconhecidos) que norteia o trabalho de formalização do assunto. Ao articular aparência e essência, como dois lados opostos e complementares de uma visão de conjunto sobre o fenômeno da estetização da política e da comercialização da cultura, o foco narrativo dá evidências de uma mirada dialético-materialista sobre a matéria histórica ${ }^{71}$.

comercial podia ser uma expressão legítima de fenômenos mais complexos do que simplesmente a ingenuidade de seus produtores" (p. 192). Com a entrada das bandas britânicas no mercado fonográfico norte-americano, em meados da década de 1960, o folk é progressivamente absorvido pelo rock, que até então era conhecido como "rockabilly", um neologismo cuja combinação de "rock" ("balançar", "sacudir") com "hillbilly" ("caipira") evidenciava sua origem no mesmo "caldo cultural" de onde surgira a música country. No final da década, o rock, ainda com resíduos do folk revival, e o country, agora em uma versão urbana e ostensivamente comercial, o "Nashville sound", situavam-se em campos opostos, estilística e politicamente. Portanto, o modo como cada gênero refletiu (ou tratou de silenciar) os conflitos sociais dos anos 1960 pode ser visto como a expressão verbal de oposições políticas dentro da indústria fonográfica.

${ }^{71}$ Ao adotar esta forma dialética, o filme avança em relação ao tratamento que os chamados "filmes de conspiração" davam ao assunto naquele período. Se em filmes como O Bebê de Rosemary (Roman Polanski, 1968), A Trama (Alan J. Pakula, 1974), Rede de Intrigas (Sidney Lumet, 1976), dentre outros, as relações de dominação política e econômica são vistas, via de regra, como o resultado de uma grande conspiração (demoníaca, política, criminosa, midiática, etc.), cuja origem permanece misteriosa (como convém a toda conspiração), no primeiro quadro temático de Nashville a imagem rígida que a dominação assume na esfera pública é 
A imagem resultante da montagem entre as duas sequências expõe o esforço de construção de uma hegemonia conservadora nos EUA a partir do final da década de 1960 não como um fato consumado, mas sim como um processo contraditório, por meio do qual a produção da cultura se converte em um sistema de poder, uma arena onde conflitos individuais ganham o sentido político de antagonismos de classe: se o materialismo histórico parte da constatação de que "as ideias [...] da classe dominante são, em todas as épocas, as ideias dominantes; ou seja, a classe que é a força material dominante da sociedade é, ao mesmo tempo, sua força espiritual dominante" ${ }^{\prime 2}$, a representação da produção ideológica na cena como um trabalho cotidiano, no qual cada gesto de dominação se depara com outros tantos gestos de resistência, lembra que a realização do desejo das classes opressoras de construir uma hegemonia total, que recubra toda a dissonância, é impedida pela própria dialética do processo histórico, cujo movimento surge deste embate incessante e cotidiano entre interesses de classe antagônicos. Como resultado, em vez de partir do modelo crítico frankfurtiano, que vê a indústria cultural como um bloco coeso e incontestado, o foco narrativo constrói uma imagem da produção industrial da cultura como um processo político e histórico, em que o aparato técnico e estético usado para oprimir é também um "terreno disputado" pelas classes em luta ${ }^{73}$. No final, a interrupção da gravação de "200 Years" é o

dialeticamente articulada à sua causa material: as relações de dominação no espaço do trabalho. Para uma análise dos erros e acertos dos filmes de conspiração, ver SOARES, Marcos. O filme de conspiração e a ascensão da nova direita nos Estados Unidos. Revista Lumen et Virtus. v. III no 6. p. $152-174$.

${ }^{72}$ MARX, Karl \& ENGELS, Friedrich. A Ideologia Alemã. p. 78.

${ }^{73}$ Trata-se, portanto, de uma visão do significado político das indústrias culturais mais próxima daquela que se deduz da análise de Michael Denning sobre a formação de uma "Frente Cultural" de esquerda nos EUA. Para Denning, não é possível entender a inclinação política que a cultura norte-americana ganha nos anos 1930 sem levar em conta o ativismo trabalhista de esquerda em dois fronts: as instituições culturais do Estado e as novas indústrias culturais que empregavam artistas e técnicos de origem proletária. Em vez de encarar o desenvolvimento do aparato cultural (o conjunto de instituições culturais do Estado e indústrias culturais) como uma degradação da arte e uma transformação do público em uma massa de consumidores passivos, Denning prefere sublinhar que "o coração do novo público de massas era a classe trabalhadora urbana", o que obrigava a cultura comercial a assumir "os sotaques das ruas e dos cortiços urbanos". Era comum que os "empreendedores" das indústrias culturais em ascensão tivessem "experiência em entretenimentos urbanos menos respeitáveis e recrutassem artistas e técnicos no mundo do vaudeville, dando um sotaque plebeu, étnico, ao entretenimento de massas. $O$ 
lembrete simbólico de que nenhuma posição hegemônica está consolidada enquanto "a luta dos contraditórios", o próprio "motor da História", continua seu trabalho. Assim como a última frase do quadro - "Seu lugar não é em Nashville" - fica "suspensa" até ser negada pela primeira imagem do quadro seguinte (a placa sobre a fachada do aeroporto em que se lê "Bem-vindo a Nashville"), a luta cotidiana pelo uso dos meios de produção ideológica fica adiada até o próximo embate.

resultado disso é que o aparato cultural se tornou um terreno disputado tanto pela Frente Popular quanto pela publicidade, conforme estilos, stars e personagens da classe trabalhadora emergiam ao lado de inserções publicitárias." in: The Cultural Front. p. 47. Ou seja, por conta de suas peculiaridades, dentre as quais a origem social dos seus quadros de funcionários e de seu 


\section{3: uma sociedade sitiada pelo espetáculo}

O segundo "ensaio" de Nashville é composto de três sequências, cujo elemento de coerência temática é o mapeamento de uma vida social, econômica e política sitiada pelo espetáculo, quer dizer, cercada por representações falsificadas da práxis vital. Montada a partir de tomadas internas e externas do aeroporto da cidade, a primeira das três sequências focaliza os traços visíveis do processo de espetacularização: a invasão dos espaços públicos pelos negócios da indústria country, a criação de barreiras à utilização social destes espaços e sua replicação nas imagens da mídia televisiva. A segunda, tomada no estacionamento do aeroporto, faz a transição entre as outras duas e indica uma mudança de direção no "olhar narrador", pois, na terceira e última sequência, em que se encena um engarrafamento na autoestrada que leva à cidade, o objeto enfocado é o "avesso" das imagens aparentes da espetacularização, quer dizer, as bases de sustentação política e social do espetáculo.

O palco dos primeiros movimentos do foco narrativo na direção de um mapeamento da vida cotidiana sitiada é o Aeroporto Metropolitano de Nashville, aonde Barbara Jean, a estrela mais querida da cidade, chegará, após tratamento em um hospital para queimados. O acontecimento atrai uma multidão que se junta ao "vaivém" cotidiano de estrelas, profissionais variados e transeuntes, passando por esta "porta de entrada" da cidade. Também estão presentes a mídia televisiva, autoridades locais e uma banda escolar que toca em homenagem à cantora, além dos funcionários de serviços oferecidos no aeroporto (lanchonete, serviço de limusine, loja de discos). A chegada de Barbara Jean causa grande comoção e o espaço do aeroporto é logo transformado em um palco onde ela pode exibir-se ao público.

público, a indústria cultural norte-americana, enquanto processo de produção cultural, é, efetivamente, um campo em disputa, um terreno da luta de classes. 
Tudo corre como planejado até que a cantora tem um desmaio repentino, precipitando o fechamento da sequência.

Logo no plano de abertura, são contrapostos dois níveis de discurso: uma fanfarra militar, criando um "pano de fundo" sonoro, e a imagem de uma placa sobre a fachada interna do aeroporto, na qual se lê "Bemvindo a Nashville". A placa cumpre a função épica de dar título à sequência, definindo um tema: a partir deste ponto, a narração começa a construir um quadro expandido de relações sociais que caracterizam a cidade como um todo. A montagem entre a imagem da placa dando boas vindas e a fanfarra estridente ao mesmo tempo atrai e repele a atenção do espectador: enquanto a placa seduz o olhar para dentro do universo ficcional, a música fere os ouvidos, recolocando-nos em uma posição distanciada.

A mensagem que ela traz "inverte" a frase que Haven deixara no quadro anterior: "Seu lugar não é em Nashville". A alternância aqui não é apenas do sentido, mas também dos materiais (som e imagem) que compõem o filme: passa-se de uma afirmação com existência acústica para outra visual, levando o espectador a ativar, alternadamente, dois pontos distintos da percepção. Como parte da "ilusão" de realidade no cinema falado se deve, justamente, à "repressão da heterogeneidade material"74 dos seus suportes, a repetição invertida da frase ("Seu lugar não é em Nashville" e "Bem-vindo a Nashville"), alternando os meios em que é expressa, equivale a um pequeno efeito de estranhamento, a partir do qual o filme se abre como trabalho de montagem horizontal (entre sequências) e vertical (entre som e imagem). Esta inversão de sentido, e de materiais, pontua também uma nova virada no modo de enquadrar o assunto: saindo do espaço privado da produção, o foco narrativo volta a abordar a "espetacularização" da vida política como circulação de imagens, investigando agora os processos que alargam as fronteiras do mercado, fazendo-o sobrepor-se a grandes espaços de convivência social.

${ }^{74}$ DOANE, Mary Ann. Ideology and the practice of sound editing and mixing. In: WEIS, Elisabeth \& BELTON, John (ed.). Film Sound. p. 57. 
Conforme o quadro fechado na placa vai-se abrindo, a imagem é ocupada pelo movimento de transeuntes e a trilha é "povoada" por um burburinho. No plano seguinte, vemos Bill Jenkins, repórter de um canal de notícias, transmitindo o evento ao vivo. A câmera de TV está posicionada no eixo da câmera de Altman, de modo que há uma "sobreposição de telas" e podemos ver, progressivamente, o repórter sendo filmado, sua imagem em preto e branco no visor e as costas do cameraman. Com um movimento panorâmico para a direita, o "olhar narrador" redireciona o eixo de sua focalização para captar o repórter diretamente, sem a mediação do aparato do canal de TV. O procedimento serve para "desencaixar" as imagens, revelando assim dois níveis discursivos: a narração produzida pela montagem e, dentro dela, o relato dos acontecimentos que o repórter vai produzindo, acompanhado por seu operador de câmera.

Em uma tomada frontal do repórter, feita ao lado da área de manobras das aeronaves, o encaixe entre a tela de cinema e a tela de TV é total, de modo que já não se podem distinguir as fronteiras entre a cena e sua versão televisiva, produzindo no espectador do filme uma identificação momentânea com o telespectador de Jenkins. Essa identificação só é totalmente rompida nos momentos em que a narração alterna as tomadas externas, onde Jenkins produz sua reportagem, com cenas breves na área interna do aeroporto. Nas tomadas externas, mesmo quando a narração não focaliza a equipe de TV, a voz do repórter ecoa na mixagem como um "acusma" que desorienta o espectador. Tal sensação é ainda reforçada pelo fato de o espaço narrativo ser enunciado primeiro na reportagem ("Aqui fala Bill Jenkins numa reportagem especial para o Canal 2 de Notícias, direto do Aeroporto Metropolitano") para depois ser identificado na imagem.

O efeito desorientador produzido pela trilha sonora é intensificado por um grande número de sons e ruídos, dos quais a fanfarra militar é o mais estridente. Em uma das passagens pelo pátio interno das aeronaves, a banda por trás da fanfarra é revelada, junto com outros festejos 
arregimentados para receber a cantora: cheer leaders, crianças vestindo maiôs colantes e um desfile militar realizado por meninas portando réplicas de armas, tudo adornado com muito azul, vermelho e branco, como pedia aquele ano de celebrações patrióticas. O repórter televisivo anuncia os participantes desta grande festa: além dos fãs de Barbara Jean, uma série de "autoridades" locais, tais como membros da Câmara de Comércio e celebridades da indústria country. Em outras palavras, embora a chegada ao aeroporto seja apresentada como um acontecimento de interesse da cidade, Nashville não se faz representar pela oficialidade municipal, mas pela mídia televisiva, pela classe empresarial e por suas celebridades musicais favoritas. Esta substituição de uma função cívica pelo espetáculo country é sintetizada nas figuras de três mestres de cerimônias: uma autoridade da Câmara de Comércio, que recebe a cantora à porta de seu avião, o cantor Haven Hamilton, que faz o "aquecimento" do público a partir de um palanque montado no pátio interno e, finalmente, o repórter, que transmite 0 evento para seus telespectadores.

Essa troca de formas de representação - em vez de uma figura pública oficial, as forças unidas do espetáculo (negócios, stars e imprensa) - é um indício de "redução estrutural"75 da História no nível da encenação: por trás dessa substituição, adivinha-se o processo de conquista de um protagonismo político-econômico pela indústria fonográfica e negócios afins, em Nashville, ao longo das décadas de 1960 e 1970. É neste período que os negócios country fazem "a transição de uma estrutura baseada em uma rede difusa de espaços de transmissão radiofônica e performances ao vivo para uma

\footnotetext{
${ }^{75}$ A expressão é de Antonio Candido e se refere ao processo por meio do qual as formas que estruturam a vida social são captadas na obra artística, passando a constituir seus elementos organizadores mais profundos. Em um ensaio sobre os pressupostos teóricos de Candido, Roberto Schwarz faz um comentário bastante esclarecedor sobre tal processo artístico-formal: para ele, a "dialética de ordem e desordem", que funciona como elemento de mediação entre as Memórias de Um Sargento de Milícias e a sociedade brasileira da época, "é tanto o esqueleto de sustentação do romance, quanto a redução estrutural de um dado social externo à literatura e pertencente à história. Trata-se, noutras palavras, da formalização estética de um ritmo geral da sociedade brasileira da primeira metade do século XIX." SCHWARZ. Roberto. Pressupostos, salvo engano, de "Dialética da Malandragem". in: Que Horas São? p. 132.
} 
indústria fonográfica ancorada na Music Row" ${ }^{\text {"76 }}$, a área no sudoeste da região central da cidade, assim renomeada a partir da instalação de editoras de música, gravadoras e atividades relacionadas, ao longo da Avenida Sixteenth South. Rapidamente, para o desgosto de sua elite cultural, Nashville deixaria de ser conhecida como "Atenas do Sul", um apelido centenário que a identificava como um centro de excelência acadêmica, para ganhar uma nova imagem promocional: em 1962, determinados a colher os resultados políticos de seus investimentos econômicos na cidade, os homens de frente da indústria fonográfica "abordaram os líderes cívicos de Nashville a respeito da possibilidade de colaborarem na área de turismo relacionado à Semana de Música Country" na esperança

"de que a cidade desse as boas vindas aos participantes do Festival de Outono da [rádio] WSM e reconhecesse, oficialmente, um novo apelido, que se originara na imprensa especializada e que se popularizara a partir de então: Music City USA."77

Esta transformação da imagem corrente de Nashville em uma "marca comercial" dava prosseguimento às modificações em sua aparência física, trazidas pela injeção de capital em suas áreas desvalorizadas. O dinheiro que inserira um "sopro de vida" na decadente região central não se resumia aos investimentos oriundos de Wall Street, "brotando" também de uma base de acumulação formada e "engordada" pelos inúmeros trabalhadores absorvidos pelos negócios da música, tanto diretamente, como mão de obra técnica especializada, quanto indiretamente, por meio de uma rede de serviços orientados às necessidades do show business. A tentativa de captar artisticamente a forma e o ritmo dessas mudanças levou a narração a fragmentar a sequência do aeroporto em uma série de quadros breves, enfocando diferentes tipos de trabalho: cantores, equipes de produção, empresários, serviços de alimentação (lanchonete) e transporte (aviões particulares e limusines), pontos de distribuição dos produtos da indústria fonográfica (uma loja de discos especializada em country), a imprensa de

${ }^{76}$ PECKNOLD, Diane. The Selling Sound. p. 78. 
celebridades, além de amadores contratados para a festa de recepção (uma banda de música, cheer leaders e crianças para o desfile militar). Por trás desse "inventário" de trabalhos orientados ao country, adivinha-se o recorte que a narração efetua na matéria histórica, privilegiando a representação da organização econômica da cidade como um processo de concentração da vida pública em torno do espetáculo country. Portanto, a troca de comando (sai a política tradicional e entram os quadros da indústria fonográfica) figurada na cena é um elemento pontual de uma modificação mais ampla da experiência urbana em Nashville, por meio da qual, como nos conta Diane Pecknold, todos aqueles elementos que davam sentido à vida cotidiana na cidade iam ganhando uma marca comercial:

"Por volta do fim da década, a paisagem da cidade seria permanentemente reconstruída pela geografia simbólica da música country. A rua na frente do Ryman Auditorium se tornaria Opry Place e a sede da CMA [Country Music Association], na esquina das avenidas Division e Sixteenth, seria renomeada Music Square East. O aeroporto seria redecorado com uma temática country e a 'Tennessee Waltz' seria adotada como a canção-símbolo do estado."78

Portanto, a expansão da indústria country em Nashville desencadeava uma "troca de lideranças" em suas estruturas de representação, fazendo a cidade perder a aparência familiar, o caráter de "espelho cultural" da sociedade que a construíra, para tornar-se uma espécie de palco aberto para a representação do espetáculo country. Parafraseando Marx e Engels, a chegada do capital fonográfico a Nashville pôs em marcha um processo de modernização capitalista sob cuja força "tudo o que era sólido e

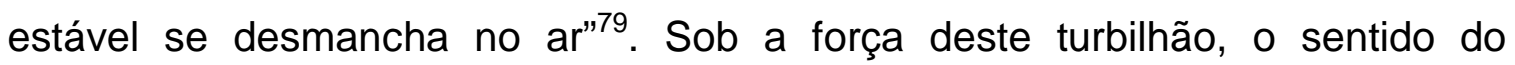
magnetismo da cidade se complicava, ao mesmo tempo atraindo uma população itinerante de músicos e técnicos de passagem por seus estúdios e repelindo os antigos residentes não aproveitados pelas novas atividades econômicas. Neste sentido, é uma evidência de "acuidade crítica" o fato de que a narração tenha

\footnotetext{
${ }_{78}^{77}$ PECKNOLD, Diane. The Selling Sound. p. 183.

${ }^{78}$ Ibid., p. 189.
} 
escolhido o aeroporto, lugar de atração e repulsão, como "metáfora" visual para toda a extensão do espaço urbano; ambos seduzem o olhar com imagens comerciais estetizadas, dando forma ao sonho de ascensão social, e segregam a maior parte da população, com uma estrutura produtiva crescentemente especializada.

De fato, o uso cotidiano do aeroporto de Nashville propicia uma imagem concreta de uma sociedade regida pelas leis do mercado. Neste espaço de convivência, os sujeitos podem experimentar a forma de circulação da mercadoria (a troca constante de lugar entre mercadoria e dinheiro) sem o inconveniente de ter de transformar-se em mercadoria (como na prostituição ou na venda da força de trabalho): na "cidade da música", cada passageiro que parte em um avião no qual chegara um star tem a sensação ilusória de equivalência com o "outro", pois efetivamente ocupa um lugar físico onde antes estivera um sujeito com maior "valor de mercado" do que o seu. Circulando livremente pela área de desembarque, onde vai topando com cantores famosos, Martha, uma desconhecida, experimenta essa "equivalência formal" com os outros usuários, o que dá a ela a coragem para abordar, com naturalidade, um astro do rock de passagem por ali. E assim, na condição de lugar de chegadas e partidas, de trânsito constante de pessoas e imagens comerciais, o aeroporto oferece formas visuais inequívocas para a figuração de um desmanche mais amplo da vida pública, concebida como uma rede de direitos, e sua substituição por uma imagem ilusória de democracia, concebida como "liberdade de movimento", o que, no que tange à cidade, coincide com sua transformação em "Music City USA", um "parque de diversões" full time.

Para captar o processo de "espetacularização" dos espaços de convivência social na cidade em seu movimento, a narração se valeu de formas dialéticas de representação. A partir de uma série de planos curtos, justapostos em uma montagem rápida e ritmada, o aeroporto não é apresentado como um ambiente completo, "transparente", mas sim como um

\footnotetext{
${ }^{79}$ MARX, Karl \& ENGELS, Friedrich. Manifesto Comunista. p. 43.
} 
acúmulo de fragmentos. A variação constante dos ângulos de tomada e as inúmeras fontes adicionadas à trilha sonora desafiam nossa capacidade de inferir uma esfera pública a partir de materiais em constante transformação. Mimetizando vozes, dissonantes ou de apoio, abafadas ou ressaltadas, perplexas ou maravilhadas diante da "espetacularização" da vida social, essas imagens e sons produzem desorientação, exigindo que a visão se afie e que o ouvido esteja alerta, de modo a discernir contornos e formas em uma montagem que se move em reviravoltas.

Diante da modificação da vida cotidiana até o ponto de arriscar tornar-se irreconhecível, a função de moradia da cidade deixa de ser um dado óbvio, despertando a curiosidade do "olhar narrador" que, na lanchonete do aeroporto, joga luz sobre a seguinte conversa: Mr. Green, um antigo residente ouve de um anônimo a estranha pergunta "o que o senhor está fazendo em Nashville?", respondendo com um prosaico "eu moro aqui". Essa pergunta, repetida outras vezes ao longo do filme, assim como as inúmeras referências ao nome da cidade, parecem oferecer uma compensação simbólica a "sujeitos sem lastro" que, lançados em uma flutuação incerta pelo avanço do capital fonográfico sobre suas vidas, tateiam no vazio em busca de referenciais. É como se cada personagem que pergunta "o que você está fazendo em Nashville?" buscasse no interlocutor uma resposta que o assegure de ocupar ainda um lugar social na cidade que, no entanto, só pode responder com o eco monótono de seu "nome de marca", reproduzido em uma infinidade de placas, anúncios, reportagens e transações comerciais: "Nashville, Nashville, Nashville..."

Ao sugerir como os sujeitos solapados pelo processo de modernização ficavam "soltos" sobre a superfície social da nova cidade espetacularizada, a narração tocava num movimento histórico muito mais amplo, a saber: a ruptura com a base de referência do valor econômico a partir do "padrão-ouro", até então o cerne do sistema internacional de pagamentos acordado em Bretton Woods, no estado norte-americano de New Hampshire, em 
1944, e modelo de sustentação das políticas de promoção do "estado de bemestar social" no pós-guerra. Diante de um cenário interno desfavorável e já visando a campanha à reeleição em 1972, Nixon se reunira com sua equipe econômica numa "agourenta" sexta-feira, 13 de agosto de 1971, na casa de campo presidencial, em Camp David, Maryland. Dois dias depois, faria um pronunciamento à nação explicando um plano econômico em que repudiava "unilateralmente o compromisso de manter o dólar conversível ao ouro." ${ }^{80} \mathrm{Com}$ tal medida, foi disparada a "crise do dólar" e a política financeira e cambial dos EUA, assim como de seus parceiros econômicos, passou a flutuar em uma trajetória oscilante de bolhas e quebras ${ }^{81}$. Do ponto de vista simbólico, interessa pensar que a unidade monetária, na sua função de "equivalente geral", quer dizer, de imagem para a qual todas as mercadorias "olham" buscando aferir seu valor, perdia, com o rompimento do lastro com o ouro, o seu próprio ponto de referência, flutuando desancorada numa economia crescentemente "virtual". Neste sentido, a "crise de identidade" das personagens solicitadas a responder "o que fazem em Nashville" pode ser lida como o espelhamento subjetivo de problemas estruturais do capitalismo financeiro a partir dos anos 1970.

\footnotetext{
${ }^{80}$ SINGER, Paul. Para Entender o Mundo Financeiro. p. 105.

$81 \mathrm{Em}$ sua história econômica dos anos Nixon, Allen Matusow sublinha as consequências políticas e econômicas da NEP (New Economic Policy), inadvertidamente nomeada com a mesma abreviação utilizada por Lênin nos primeiros anos da URSS: "Do ponto de vista político, a NEP funcionou. Na primavera de 1971, o Gallup havia noticiado que, numa corrida com três candidatos que ainda incluía George Wallace, o democrata Edmund Muskie ganhava de Nixon por dois pontos percentuais. Imediatamente após o dia 15 de agosto, Nixon havia passado seis pontos na frente e, em outubro, ainda colhendo os frutos de sua intervenção no mercado financeiro, abrira oito pontos de vantagem. [...]. Do ponto de vista econômico, a NEP não justificou a propaganda feita pela equipe de Nixon. [...]. Tomado em seu conjunto, o plano econômico contribuiu apenas marginalmente para as forças que alavancariam a economia em 1972". Embora Matusow reconheça a intervenção pessoal de Nixon no rompimento com o "padrão-ouro", ele enfatiza a conjuntura econômica mais ampla, vendo no desmanche do sistema internacional de pagamentos nos anos 1970 um momento decisivo no colapso do welfare state e das políticas social-democratas do pós-guerra: "A principal consequência da NEP foi livrar os EUA do padrão-ouro. Alguns conservadores viram no abandono do ouro em Camp David o maior crime político de Nixon e o culparam pela década de inflação que se seguiu. $\mathrm{Na}$ verdade, havia muito tempo os EUA já se recusavam a disciplinar sua economia na defesa do ouro e, de fato, o dólar já não era conversível havia muitos anos. Foram as demandas dos eleitores nas democracias ocidentais, especialmente nos EUA, por políticas expansivas de promoção do pleno emprego, que determinaram o fim do padrão-ouro. Nixon e Connally [John, Secretário do Tesouro] simplesmente ajudaram a decidir o momento de sua queda". in: MATUSOW, Allen. Nixon's Economy. p. $179-180$.
} 
Na mesma cena em que Mr. Green tenta definir seu lugar na cidade, a narração sublinha o contraste entre os modos como as diferentes gerações reagiam ao desmanche da vida social reconhecível, sugerindo que a juventude, mais maleável às mudanças, redirecionava suas aspirações de acordo com a atração exercida pela promessa de uma carreira musical; entre um sundae e outro, Sueleen Gay, a garçonete que serve Mr. Green, mostra a um freguês a música que compôs e que espera utilizar como passaporte de seu local de trabalho atual para o mundo do country, o novo centro econômico da cidade.

O ritmo das mudanças por que passavam Nashville e o país inteiro impunha dificuldades também a Altman e sua roteirista Joan Tewkesbury no momento de definir os contornos da narrativa. Esse desafio à representação começou a ser superado quando os artistas se deram conta de que a própria geografia da cidade poderia fornecer o princípio organizador para a captação e a formalização da matéria histórica. É possível reconstruir estes dois momentos do trabalho de Altman e Tewkesbury a partir de informações contidas no livro de Jan Stuart sobre as diferentes fases de produção e lançamento do filme; nele, Stuart nos conta, por exemplo, que Tewkesbury fez uma primeira viagem de pesquisa a Nashville, colhendo muitas informações, mas não conseguindo concatená-las em uma narrativa:

"Saindo do Exit/ln [um bar utilizado como locação], Joan Tewkesbury voltou correndo ao hotel em que estava e escreveu à máquina as primeiras palavras do roteiro. 'Era a minha versão de um ensaio escrito por Joan Didion [romancista e ensaísta norte-americana] em um quarto de hotel no Havaí, no momento em que irrompera a guerra do Vietnã. A diferença é que eu estava em Nashville, olhando para toda a insanidade desta cidadezinha idiota, preocupada por ter deixado meus filhos em casa, mas confiante de que havia algo de extremamente poderoso ocorrendo naquela cidade e naquele momento histórico. Stringbean [David Akeman, banjoísta country] havia sido assassinado [em 1973, em um assalto a sua casa], as bandas de rock inglesas estavam chegando à cidade pela primeira vez e a situação política do país andava muito estranha. Eu não conseguia encontrar uma 'pegada' naquele material até que eu descobri a geografia da cidade. Aquilo juntou os materiais dispersos para mim e eu sabia que Bob [Robert Altman] se daria muito bem com este tipo de construção'. 
Tewkesbury telefonou a Altman dizendo, 'seu filme está aqui em algum lugar, mas eu ainda não estou muito certa de como ele se traduzirá em um roteiro. Mas acho que estou encontrando a forma de fazê-lo. Trata-se de uma história singular sem contar apenas uma história'. Altman respondeu, com escárnio impaciente, 'Ah, sim, claro'.

Quando se encontraram, Tewkesbury mostrou a Altman as fotos de algumas locações possíveis, explicando como a cidade havia sido construída em círculo, o que obrigava as vidas das pessoas a se sobreporem naturalmente no seu cotidiano. Aquilo tocou Altman que, de acordo com Ned Beatty [ator que interpreta o advogado Del Reese no filme], havia dito uma vez que 'ele sempre quisera fazer um filme em que uma personagem entra em uma porta giratória e outra personagem é que sai por ela e você [o espectador] tem de seguir esta segunda personagem."”82

De fato, a imagem de uma "porta giratória" oferece uma excelente metáfora visual para entendermos a forma de organização do espaço na sequência do aeroporto, em que a atenção do espectador deve movimentar-se em pequenos saltos, tentando perseguir as entradas e saídas de personagens no enquadramento e na trilha sonora. Trata-se de um princípio de construção verificável em outras sequências, tais como o "comercial" que abre o filme, exibindo as personagens e os títulos de suas canções em um movimento giratório de imagens de capas de discos, em que o aparecimento ascendente de uma determina sempre o desaparecimento de outra. No limite, é este mesmo movimento que dá forma à organização de todos os quadros temáticos no filme, que ao serem dispostos não em progressão linear, mas em justaposição simples, fazendo a última sequência, a do comício de Walker, retomar a primeira, a do carro de som na avenida, acabam eles também descrevendo uma trajetória circular.

Parece-nos ser possível encarar esta multiplicação de imagens de circularidade no filme como um indício de formalização do tema: no nível da história, as personagens agem e se relacionam movidas por um ímpeto à mobilidade, tanto espacial quanto social, do qual a figuração mais forte é a sua chegada a Nashville e sua disputa visando a escalar a hierarquia country.

${ }^{82}$ STUART, Jan. The Nashville Chronicles. p. 59-60 
Entretanto, o que encontram é um sistema de produção e circulação da cultura que barra o movimento ascendente, força os aspirantes a star a se contentarem com a posição de espectadores e, ao mesmo tempo, mantém esse sonho de ascensão. Assim como a moeda desregulada, as personagens são forçadas a um movimento tautológico em torno de um centro espetacular que elas não compreendem, na esperança de ser absorvidas por ele, na próxima virada da "porta giratória".

Em outro ponto do aeroporto, são enfocadas algumas consequências subjetivas do redirecionamento do sonho de ascensão social em torno do show business na cidade: na área de desembarque, Martha espera por Mr. Green, marido de sua tia doente. Por meio de uma seta horizontal impressa sobre uma placa em que se lê "todas as pessoas que entram no saguão são revistadas", a narração chama a atenção do espectador para a presença de Martha no lado direito do quadro. Usando sapatos de plataforma, meias coloridas, shorts, blusa curta, boina e quatro bolsas estilo hippie atravessadas entre os ombros, a caracterização exterior da personagem sugere uma imagem híbrida, resultante do "cruzamento" de signos da contracultura com elementos da moda pop dos anos 1960. Ao ser recebida por Mr. Green, Martha anuncia: "mudei de nome; meu nome agora é L. A. Joan". Meio desnorteado com a forma de saudação, Mr. Green tenta introduzir o tema da tia doente ("Sua tia está no hospital, não está se sentindo muito bem e gostaria de falar com você"), mas a prioridade de Martha é conseguir o autógrafo de um cantor que acabava de passar pelo saguão (“Espere um minuto; aquele cara ali é um astro do rock”). Interrompida pela sedução do star da música, a conversa sobre a tia doente será retomada e adiada outras vezes no decorrer da história, sem que Martha chegue a encontrar Mrs. Green, cuja morte acaba por frustrar nossas expectativas de descobrir o que ela gostaria de dizer à sobrinha.

Por meio da atenção dividida da personagem, entre as "responsabilidades familiares" e as atrações do mundo das "celebridades", a narração figura as exigências subjetivas trazidas pela indústria cultural à 
população de Nashville. A nova orientação da vida cotidiana e as necessidades específicas da reprodução do capital fonográfico compelem os sujeitos desejosos de integração a adotar uma forma de atuação "sem lastros", análoga ao "movimento geral das coisas", rompendo com o lugar, com sistemas de valores arraigados e, principalmente, com o passado. Em Martha, o indício mais forte desta ruptura é a troca do nome próprio, aquele elemento de identificação que, ao apontar para um passado anterior à existência do sujeito (quando seu nome foi escolhido), o conecta à sua própria "história pessoal" e à experiência social em comum ${ }^{83}$. No sentido inverso, "L. A. Joan", o nome adotado, aponta para frente, ganhando a aparência de expressão radical de uma individualidade que se rebela contra as pressões sociais; afinal, trata-se do nome que 0 indivíduo escolheu para si e em favor do qual abandona aquele outro com que o grupo social o designava. Porém, na sua composição a partir de duas marcas publicitárias consagradas - as iniciais utilizadas na promoção comercial da cidade de Los Angeles seguidas do prenome de uma cantora folk muito conhecida nos anos $1960^{84}$ - adivinha-se o passaporte para uma diluição do indivíduo na única universalidade oferecida pela sociedade do espetáculo: a equiparação entre pessoas e mercadorias, em um espaço de circulação de imagens.

Por trás do nome adotado por Martha, descobre-se o próprio trabalho da "dialética do esclarecimento" no que se refere à linguagem

\footnotetext{
${ }^{83} \mathrm{Na}$ verdade, como aponta Isleide Fontenelle, a adoção de uma marca publicitária é uma complicação recente das relações entre corpo e lugar, numa história de libertação e desamparo que remonta ao movimento de ruptura dos servos com o latifúndio, atraídos pelas cidades emancipadas do século XIII e pela promessa de uso livre de seus corpos contida nas corporações artesanais. A partir de um resumo excelente dos principais argumentos do livro de Richard Sennett sobre a história das relações entre o corpo e a cidade (Carne e Pedra), Fontenelle lança a tese de que "o fetiche da marca pode muito bem ser a ilustração do ponto de chegada de um longo processo no qual a intensa mobilidade dos corpos provocou, no sujeito, uma busca por algum sentido de permanência" para a qual as marcas publicitárias se oferecem como resposta e forma de satisfação. FONTENELLE, Isleide. O Nome da Marca. p. 307.

${ }^{84}$ É provável que tenha havido aqui uma "autocitação" da roteirista Joan Tewkesbury ao nomear a personagem "Joan". Porém, como para a análise fílmica o que interessa são as conotações que as palavras e demais elementos de composição ganham ao serem incorporados pelo discurso, parece-nos mais lógico supor que, na história, o nome da personagem ecoa, sobretudo quando associado ao figurino que a caracteriza, o "nome artístico" de Joan Baez, muito mais difundido do que o nome da roteirista de Nashville.
} 
publicitária: a passagem incessante entre as forças antagônicas da razão, presente na escolha calculada de um nome que visa a aumentar as chances estatísticas de integração a um setor produtivo privilegiado, e da "magia", invocada no momento em que este nome deve antecipar, simbolicamente, como na "mimese encantatória", uma trajetória ascendente para a personagem ${ }^{85}$. No outro extremo, estão os tios velhos, designados ao longo do filme apenas por seu sobrenome - Mr. e Mrs. Green; neste antropônimo partilhado, em que o casal dilui suas individualidades em favor de uma identificação segura em comum, deposita-se uma "verdade mítico-histórica" que, diante do ritmo das mudanças, torna-se anacrônica e é ameaçada de perder-se de vez. ${ }^{86} \mathrm{O}$ fato de

\begin{abstract}
${ }^{85}$ Adorno e Horkheimer já haviam observado que a "modernização" dos nomes próprios segundo as modas publicitárias revelava que o sujeito que adota um "nome de marca" calculado para promover o sucesso rompe uma ligação linguística entre si e a História, abrindo a possibilidade para a administração de sua vida subjetiva pela linguagem da indústria cultural: "Se, antes de sua racionalização, a palavra permitira não só a nostalgia mas também a mentira, a palavra racionalizada transformou-se em uma camisa de força para a nostalgia, muito mais do que para a mentira. A cegueira e o mutismo dos fatos a que o positivismo reduziu o mundo estendem-se à própria linguagem, que se limita ao registro desses dados. Assim, as próprias designações se tornam impenetráveis, elas adquirem uma contundência, uma força de adesão e repulsão que as assimila a seu extremo oposto, as fórmulas de encantamento mágico. Elas voltam a operar como uma espécie de manipulações, seja para compor o nome da diva no estúdio com base na experiência estatística, seja para lançar o anátema sobre o governo voltado para o bem-estar social recorrendo a nomes tabus como 'burocratas' e 'intelectuais', seja acobertando a infâmia com o nome da Pátria. Sobretudo o nome, ao qual a magia se prende de preferência, está passando atualmente por uma alteração química. Ele está se transformando em designações arbitrárias e manejáveis, cuja eficácia se pode agora, é verdade, calcular, mas que por isso mesmo se tornou tão despótica como em sua forma arcaica. Os prenomes, que são resíduos arcaicos, foram modernizados: ou bem mediante uma estilização que os transformou em marcas publicitárias - para os astros de cinema os sobrenomes também são prenomes - ou bem mediante uma padronização coletiva". Dialética do Esclarecimento. p. 154.
\end{abstract}

${ }^{86}$ Para se ter uma ideia da quantidade de camadas sedimentares contidas neste antropônimo, veja-se a seguinte introdução de uma genealogia da família Green, publicada por um coletivo de autores em 1972: "o sobrenome Green, tal como é usado hoje nos EUA, provém de duas origens: a vida aldeã na Inglaterra medieval e a imigração de judeus, da região central da Europa para os EUA, durante a Guerra Civil. Algumas das variantes trazidas por esses judeus imigrantes incluem Greenberg ('montanha verde'), Greenblatt ('folha verde'), Greenstein ('pedra verde'), Greenwald ('floresta verde'), Greenbaum ('árvore verde'), além de Greenglass ('vidro verde', indubitavelmente assim originado como nome de algum artesão vidreiro). A maioria dessas famílias anglicizou seus nomes, eliminando a forma alemã 'Grun' que os precedia; muitos foram adiante, passando a grafá-los simplesmente como Green ou Greene. Na Inglaterra, a maior parte dos nomes começando em 'Green' se refere a florestas, campos e à magia primitiva associada a rituais de fertilidade. Três associações se destacam: o 'green' era um grande prado aberto comunal utilizado como área de pastagem para os animais criados nos vilarejos. Muitas pessoas retiravam seus nomes de marcas geográficas; 'de la', um prefixo frequentemente usado na frente do sobrenome, significa 'da'; assim, por exemplo, o nome Robertus de la Greene, que aparece em um registro tributário do século XIII, era 'Roberto do prado' ['of the green', em inglês] ou, 
Mr. Green ser solicitado a explicar o seu lugar em Nashville pode ser interpretado como um sinal da fragilidade dos últimos restos de vida comunitária na cidade; já a morte anônima de Mrs. Green, em um quarto de hospital, longe do "olhar narrador", impossibilitando a recuperação daquilo que ela tinha a nos contar e a continuação da história popular de que seu nome era um elo, reencena, no plano simbólico, o destino final destas últimas figuras "anacrônicas" e o rastro de empobrecimento que sua eliminação deixa na vida social.

Martha, entretanto, parece vivenciar esta "morte" do sentido compartilhado não como uma perda, mas sim como uma experiência gozosa. Inventando aparências e denominações para si, a personagem alegremente recalca a memória de sua vida pregressa, equipando-se para a nova realidade econômica que se apresentava. Assim, ela repete, no plano individual, o mesmo processo de "desidentificação" coletiva imposto à cidade à época da adoção do apelido "Music City, USA". Ao despir-se do "figurino ultrapassado" de "Atenas do Sul", Nashville também ficava "zerada", pronta para os desenvolvimentos prometidos pelo capital fonográfico.

muito provavelmente, 'Roberto que vive no prado'. Uma segunda origem possível se liga às celebrações medievais da chegada da primavera. Na maioria das comunidades rurais inglesas, os festivais da primavera remontavam a um antigo banquete pagão, em que sacerdotes druidas abençoavam o solo, os animais e a população, ungindo a todos para que florescessem e frutificassem. Em algumas aldeias, o mestre de cerimônias destes festivais de fertilidade era chamado de 'the Green Man' [O Homem Verde]. Normalmente o jovem mais viril e belo da aldeia, o Green Man se cobria de folhagens e brandia um ramo verde, personificando a primavera, a vitalidade e o renascimento, da mesma forma que figuras similares em outras religiões e mitologias. Alguns dos primeiros homens a adotarem o nome Green devem tê-lo feito pela influência desta figura central nos antigos festejos primaveris. Uma terceira ligação com o nome Green vem da lendária figura de Robin Hood. Dados do censo normando parecem documentar a lenda: Ward ('guarda') of the Green, Robertus de la Grene, Robertus Hood, o fugitivo, e até mesmo Ricardus filius Parvi Johannes ('Ricardo, filho do pequeno João'). Seja qual for a história verdadeira, o que hoje sabemos é que, no final do século XIII, a figura de Robin Hood, vestido em 'verde Lincoln', suplantou o Green Man dos antigos festivais da primavera e o sobrenome Greenman ganhou para os ingleses a conotação de 'guardião da floresta'”. American Genealogical Research Institute. The Green Family. p. 4. Nestas linhas iniciais, fica mais claro como o nome de família liga o sujeito ao passado histórico (aqui, tanto a história mais próxima, dos movimentos migratórios no século XIX, durante a Guerra Civil, quanto a longínqua, da vida aldeã inglesa no século XIII) e também mágico-lendário, uma vez que o nome recupera rituais de fertilidade de um passado imemorial e as histórias em torno da lenda de Robin Hood. 
Entretanto, do ponto de vista psicossocial, o processo de ruptura com a História só é suportável na medida em que a lembrança da identidade abandonada não se transforme em um experiência traumática, o que exige a generalização de uma "ética da indiferença" ${ }^{87}$. A narração sublinha, com ênfases distintas, o funcionamento dessa "ética" nas relações intersubjetivas e na relação dos sujeitos com o espaço: se a falta de tempo de Martha para as últimas palavras da tia moribunda é um signo de sua "desumanização", a complicação do magnetismo de Nashville, ao mesmo tempo atraindo e repelindo residentes e forasteiros, é o indício de que a indiferença é o "azeite" da generalidade de relações humanas na cidade.

O custo do processo é compartilhado, e o indivíduo e a sociedade indiferentes, que se dobram sem resistência ao ímpeto modernizador, correm o risco de tornar-se, eles próprios, indiferenciados. A cidade buscava encontrar um sentido de permanência diante da liquefação de sua aparência por meio da multiplicação de sinais luminosos de seu nome, ou seja, inventando fetiches que a protegessem da "angústia" da "perda da identidade"88. O resultado, porém, é que a cidade ganhava, cada vez mais, a aparência de "parque de atrações", um lugar onde os sujeitos se reúnem para assistir a "performances" e não mais para a satisfação de suas necessidades

${ }^{87}$ O termo é utilizado por Richard Sennett para designar a "ética" adotada pelos sujeitos como resposta à necessidade material de circular com a desenvoltura e a indiferença das mercadorias, quer dizer, sem apegar-se ao meio espacial e social de origem. (Carne e Pedra. p. 263). Walter Benjamin já resvalara nessa discussão ao argumentar que a "experiência do choque", tátil, visual, sonoro, etc., nas grandes cidades prepara os sujeitos para suportar, com indiferença, novos choques. "Quanto maior é a participação do fator do choque em cada uma das impressões, [...] tanto menos essas impressões serão incorporadas à experiência" e, portanto, menores serão as chances de que resultem em um trauma e maiores as possibilidades de sobrevivência no ambiente hostil da cidade moderna, dominada pelo capital. BENJAMIN, Walter. Sobre alguns temas em Baudelaire. in: Charles Baudelaire: um lírico no auge do capitalismo. p. 115.

${ }^{88} \mathrm{O}$ mecanismo psicossocial aqui é análogo àquele que alivia a "angústia da castração" na esfera individual: as imagens que repetem "Nashville, Nashville, Nashville", oferecendo compensações ilusórias pela perda da identidade cultural solapada pela modernização, ao mesmo tempo apagam e rememoram a "dor psíquica" desta perda. Sobre o mecanismo do fetichismo e sua relação com o "trauma da castração", ver FREUD, Sigmund. Fetichismo. in: $O$ Futuro de Uma llusão, o Mal-Estar na Civilização e outros trabalhos. p. 155 - 159. 
sociais $^{89}$. Em Martha, o processo é análogo e a personagem experimenta vários figurinos ao longo do filme, como se estivesse à procura de uma imagem visual na qual o nome "L. A. Joan" pudesse finalmente fixar-se. Em uma dessas trocas, a personagem sai de um banheiro público com uma peruca diferente daquela com que entrou; à porta, já não é mais reconhecida pelo namorado que a esperava. Imediatamente, ela se descola dele e sai em busca de outro namorado.

Diante de todas essas transformações, a aterrissagem do avião de uma cantora famosa deveria ser um fato banal no cotidiano do aeroporto de Nashville. Porém, a tomada do espaço público pelos festejos de recepção de Barbara Jean, juntamente com sua transmissão ao vivo pelo repórter televisivo, transforma a chegada corriqueira em um grande acontecimento. Surge aqui a dúvida se este acontecimento é em si digno de nota, o que justificaria que o movimento de passageiros se detivesse para contemplá-lo, ou se ele se torna notável por meio de um processo de fabricação, configurando aquilo que Daniel Boorstin chamou de "pseudoacontecimento"

${ }^{89}$ Segundo Aristóteles, "'os homens se reúnem na cidade para viver, mas permanecem nela para viver a vida boa"'. Séculos mais tarde, Rousseau completou a definição, afirmando que "'casas fazem o burgo e os cidadãos a cidade". apud in: MUMFORD, Lewis. The City in History. p. 111 e 93. Se esses dois "gigantes do pensamento" ainda estiverem certos sobre a necessidade de se utilizar a promoção da "vida boa", ou seja, da cidadania, como o critério fundamental de validação da cidade, é possível que já não merecesse tal designação um aglomerado urbano como o da Nashville ficcional que, ao se transformar em uma grande vitrine para mercadorias culturais, rebaixava seus residentes à condição de espectadores passivos de uma vida social de que já não participavam.

90 Segundo Boorstin, o "pseudoacontecimento" se difere do acontecimento autêntico pelas seguintes razões: 1) é um acontecimento planejado, em vez de espontâneo; 2) seu objetivo primordial é ser reproduzido na forma de notícia, de modo que o seu sucesso é medido pela quantidade de cobertura midiática que alcança; 3 ) seu interesse é deduzido da relação ambígua entre o acontecimento fabricado e o modo como é reportado; 4) normalmente, ele funciona como uma espécie de "autoprofecia": ao dizer que um acontecimento é importante, a reportagem o torna importante. Boorstin lembra que a multiplicação de "pseudoacontecimentos" significa uma complicação da aparência da vida social: "Na era dos pseudoacontecimentos é menos a simplificação do que a complicação artificial da experiência que nos confunde. Sempre que um pseudoacontecimento compete com um acontecimento espontâneo, o pseudoacontecimento tende a dominar." BOORSTIN, Daniel J. The Image. p. 39. Seguindo o raciocínio de Boorstin, é possível entender a proliferação de "pseudoacontecimentos" em Nashville como uma resposta a um problema econômico local, a saber: a necessidade de criar "janelas de comercialização" para o incremento de mercadorias culturais que o capital fonográfico trouxe à cidade. A lógica econômica por trás da transformação das funções normais do aeroporto em elos da reprodução 
Conforme a narração alterna tomadas em que a posição do espectador se funde com a do telespectador de Jenkins com outras em que se pode ver o trabalho da equipe de TV, é possível acompanhar o próprio processo de fabricação de uma "versão sintética" da vida social pelos negócios associados à indústria fonográfica: se a instalação de um palco, lá onde deveriam ocorrer apenas chegadas e partidas, falsifica o uso do aeroporto, a sua veiculação, na forma de "pseudoacontecimento" televisivo, desdobra este espaço em uma nova abstração, "desrealizando" completamente a experiência cotidiana ao transformá-la em imagem. Na narrativa produzida por Jenkins, o aeroporto é apenas uma miragem de sua função original; captado pela reportagem, ele se transforma em setting, em espaço ficcional sobre o qual o repórter vai compondo um relato atraente. Quanto aos seus usuários, estes se transformam em elementos de composição do cenário, figuras para o consumo estético do telespectador, que nada tem a ver com aquele espaço.

Ao desalinhar e realinhar os eixos da câmera de TV com a câmera de cinema, a narração vai instaurando e apagando a presença do repórter como um desdobramento do foco narrativo, expandindo o espaço ficcional, na transmissão televisiva, para novamente comprimi-lo, ao mostrar suas condições de produção. Neste tipo de trabalho, são expostos não apenas 0 "esforço de fabricação" envolvido na reportagem, mas também as alterações inevitáveis que os conteúdos sofrem ao serem captados e dispostos pela composição fílmica. É como se, no relato de Jenkins, o "narrador" tomasse consciência de sua própria manipulação do assunto, quer dizer, dos recortes e dos pontos de vista criados por meio da seleção de ângulos, distanciamentos e enquadramentos. Em outras palavras, a reportagem televisiva funciona como um meio de expressão indireta da "autoconsciência" do discurso narrativo.

do capital fonográfico é a de sempre: em um contexto de "crise estrutural, o capital tenta absorver na sua autovalorização todas as relações sociais". LESSA, Sergio. Lukács - Ética e Política. p. 104. 
Ao mesmo tempo em que o povoamento do espaço público por um acúmulo de imagens atraentes e festivas cria uma versão sintética, fabricada, da vida social, ele também serve, como sugeriu David Cook, ao encobrimento de uma visão clara dos acontecimentos falsificados:

"[...] Nashville é [...] um filme sobre a maneira como nossa política e nossa mídia nacional de entretenimento - ambas quase indistinguíveis uma da outra trabalham constantemente para nos distrair das desigualdades massivas que caracterizam nossa sociedade e da violência de nosso passado nacional recente. Altman reconhece muitas virtudes americanas a serem admiradas, mas o tema mais importante de Nashville é o quão rápido esquecemos e enfeitamos acontecimentos tais como a terrível violência pública dos anos 1960 e as consequências humanas da guerra do Vietnã." ${ }^{91}$

Assim como ocorrera na sequência dos estúdios, a qualidade épica da narração aqui resulta da utilização de procedimentos cênicos, narrativos e técnicos que não apenas representam o funcionamento superficial da ideologia, mas também, e principalmente, o expõem como um trabalho cotidiano de repressão da História. Dentre as atividades organizadas para receber Barbara Jean estão uma grande fanfarra e um desfile patriótico realizados por meninas e adolescentes. Falando a Haven, Pearl sublinha o esforço envolvido na preparação dessas festividades: "eu quero que você saiba que elas praticaram por dois meses, depois das aulas, só para este evento". Escoltado por "balizas de banda" (as "Tennessee Twirlers"), um grupo de meninas adolescentes realiza um desfile trajando uniforme de educação física. Marchando em pelotão, ao som do hino nacional, elas giram, entre uma mão e outra, réplicas de espingardas militares, vindo a parar, um joelho ao chão e a mão direita à cabeça, em gesto de continência, de frente para o púlpito onde está instalado o equipamento de som. É deste espaço equipado tecnicamente para a emissão de uma fala pública amplificada que Haven faz a "leitura oficial" da apresentação: "Como são lindas! Vocês já viram, alguma vez, meninas mais lindas do que essas? Um dia vocês se tornarão grandes garotas como suas mamães e se lançarão à procura de um rapaz jovem, bonito e bom..." A esta

${ }^{91}$ COOK, David. A History of Narrative Film. p. 942. 
cena é intercalada uma rápida pergunta feita por Tom, astro da música, a Kelly, um soldado que esteve no Vietnã: "E aí, sargento? Já matou alguém esta semana?"

Em um contexto de impaciência generalizada com a continuação da guerra do Vietnã e de estigmatização social dos veteranos, a realização de um desfile militar com adolescentes tem a conotação de "ato político simbólico": por meio da exibição ensaiada, expressa-se um posicionamento que endossa o militarismo e a ordem patriarcal (veja-se que Haven sugere que as meninas só crescerão ao encontrar um homem), encarando-os como formas adequadas para demonstrar felicidade pelo retorno de Barbara Jean. Ou seja, até aqui a impressão que o espetáculo e a "leitura" que Haven faz dele nos causam é a de se tratar apenas de mais uma representação de ideologias conservadoras (militarismo, ordem, patriarcalismo, machismo). Essa representação da superfície ideológica é "dialetizada" por meio da pergunta de Tom - "E aí, sargento, já matou alguém esta semana?" - que funciona como uma "chave histórica" para a exposição do sentido político do desfile, quer dizer, de sua função como arma de ataque na luta de classes ${ }^{92}$.

Nesta pergunta ressoam slogans utilizados pelos movimentos contrários à guerra do Vietnã:

"Comícios e manifestações contra a guerra atraíram multidões crescentes em 1966 e 1967, com os participantes tornando-se mais ousados em seus protestos.

${ }^{92} \mathrm{O}$ termo pode soar exagerado, sobretudo se pensarmos nos antagonismos entre apoiadores e opositores da guerra como simples exemplos de "batalhas culturais". Entretanto, um exame um pouco mais profundo da origem dos grupos sociais em oposição e das formas violentas com que expressavam suas discordâncias talvez sirva para validá-lo como uma descrição correta do conflito de posições em jogo: "Está claro que a dissidência durante tempos de guerra é uma tradição norte-americana firmemente estabelecida; porém, a guerra do Vietnã suscitou uma oposição mais generalizada e apaixonada do que qualquer outra guerra de que os EUA participaram. Ela ocorreu em uma época de revolta social, quando os norte-americanos questionavam seus valores e instituições mais do que em qualquer outro período de sua história. Ela ocorreu em uma época de luta generalizada. Ela ocorreu quando as 'verdades estabelecidas' sobre a Guerra Fria eram postas em questão. A guerra do Vietnã, portanto, dividiu os norteamericanos com uma intensidade comparável apenas ao debate sobre a escravidão um século antes. Ela dividiu empresas, igrejas e campi universitários, vizinhos e famílias, lançando classe contra classe." HERRING, George. America's Longest War. p. 186. 
Manifestantes marchavam diariamente ao redor da Casa Branca cantando 'Hey, hey, LBJ, how many kids have you killed today?' [E aí, Presidente Lyndon Baines Johnson, quantas crianças o senhor matou hoje?] e 'Ho, Ho, Ho Chi Minh, NLF is going to win' [Ho, Ho, Ho Chi Min, o Vietcongue, a Frente Nacional para a Libertação do Vietnã, é que vai vencer]." ${ }^{93}$

$\mathrm{Na}$ qualidade de "comentário épico", a pergunta de Tom ilumina o desfile das meninas e exige que se faça uma leitura alegóricopsicanalítica de sua forma aparente, desmascarando-a como um registro distorcido que o trabalho de repressão da História deixou na superfície da representação. Neste modo de interpretar, a volta de Barbara Jean após a luta pela saúde em um hospital para queimados evoca, em sua forma "gestual" (a recepção com festividades militares, a tribuna montada), o conteúdo histórico situado fora da obra, a saber: o retorno dos soldados derrotados no Vietnã. O recalque da consciência histórica aqui se dá por meio da recuperação/inversão de uma série de signos reconhecíveis da luta social em curso naquele momento: as manifestações espontâneas, nas quais os veteranos eram frequentemente recebidos como "baby killers" ${ }^{\text {", }}$, são incorporadas e "apagadas" no desfile militar ensaiado, por meio do qual a volta da cantora é tratada como uma ocasião festiva; da mesma forma, também deixa traços na superfície ideológica a repressão do conteúdo de rebeldia de uma juventude "contra a cultura", que defendia radicalizar a oposição à guerra por meio da completa modificação do mundo herdado de seus pais. É este conteúdo que a "chave alegórica" permite desencavar, como o "negativo" da imagem de uma adolescência ordeira, uniformizada e, segundo as palavras de Haven, inclinada a conservar a velha sociedade patriarcal e militarista ("Um dia vocês se tornarão grandes garotas como suas mamães e se lançarão à procura de um rapaz jovem, bonito e bom...").

\footnotetext{
${ }^{93}$ HERRING, George. America's Longest War. p. 189.

${ }^{94}$ Segundo nos conta um dicionário especializado, "baby killer", ou seja, "assassino de bebês", era o "termo pejorativo usado para identificar os veteranos do Vietnã que voltavam da guerra entre o final dos anos 1960 e começo dos 1970". Urban Dictionary. Disponível em http://www.urbandictionary.com/define.php?term=baby+killer
} 
Ou seja, pela mediação do comentário épico contido na pergunta de Tom, a ideologia deixa de ser pensada como um encobrimento puro e simples da consciência histórica e passa a valer como uma "alegoria", uma imagem desfigurada, muitas vezes irreconhecível, mas nem por isso menos reveladora do processo de luta cultural por trás de sua constituição ${ }^{95}$. Trata-se de um modo de representar simbolicamente a guerra do Vietnã que, embora tenha sido derrotado na produção cinematográfica posterior, tem a vantagem, do ponto de vista de uma estratégia artística de esquerda, de não projetar a visão conservadora vitoriosa como um fato incontestável e sim como o sintoma de uma sociabilidade doente, reprimida e neurótica ${ }^{96}$.

\footnotetext{
${ }^{95}$ Pensar o desfile militar preparado para receber Barbara Jean como uma imagem que "reprime conservando" o processo histórico é pensá-lo no sentido que Walter Benjamin dava ao termo "alegoria". "O recurso à alegoria, segundo Benjamin, nos é imposto pelas condições históricas em que nos encontramos; somos sobreviventes de uma destruição paulatina de todos os grandes valores antigos, que foram aviltados e transformados em escombros pela mercantilização da vida. 'As alegorias são, no reino do pensamento, o que as ruínas são no reino das coisas." KONDER, Leandro. Walter Benjamin: o marxismo da melancolia. p. 28. Neste sentido, parece-nos justo pensar que um trauma histórico como a guerra do Vietnã só encontrasse expressão, naquele momento em que ele ainda produzia feridas, por meio de alegorias.

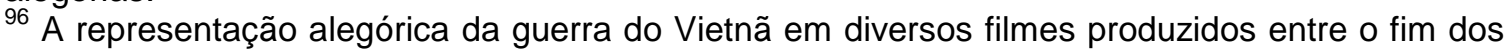
anos 1960 e começo dos 1970 pode ser atribuída à dificuldade de expressão direta do "sentimento de desespero cultural" associado à "convicção de que os Estados Unidos estavam lutando uma guerra imoral e sem sentido no sudeste asiático". COOK, David. Lost Illusions. p. 174. Em M.A.S.H. (1970), Altman tentara distanciar-se emocionalmente do assunto por meio do humor negro e da alegoria, transportando a representação do dia a dia de um grupo de soldados saídos dos anos 1960 para um acampamento militar durante a Guerra da Coreia. Altman ainda retornaria ao assunto, em 1983, com O Exército Inútil (Streamers); sobre este filme, ver TROVÃO, Flávio Vilas-Bôas. O Exército Inútil de Robert Altman. Com a retirada das tropas norteamericanas em 1975, saiu de cena a alegoria e entrou uma leitura conservadora da guerra, primeiro em filmes centrados nos traumas individuais de um veterano tornado assassino psicopata (por exemplo, Taxi Driver, Martin Scorcese, 1976); depois em uma utilização do Vietnã como o tema de uma discussão abstrata e universalizante dos horrores escondidos na alma humana (Apocalipse Now, Francis Ford Coppola, 1979); posteriormente, com as séries estreladas por Chuck Norris e Sylvester Stallone que, inspiradas pela intervenção norteamericana na Nicarágua e em El Salvador, "revisitavam" o Vietnã e invertiam a dinâmica militar da guerra, retratando um "superveterano" que, no retorno ao campo de batalhas, vencia, sozinho, os guerrilheiros vietcongues, e ensinava aos EUA que um indivíduo esforçado pode mais do que o exército norte-americano inteiro; finalmente, no final dos anos 1980, com filmes como Platoon (Oliver Stone, 1986) e Pecados de Guerra (Brian de Palma, 1989) que, ao propor um tratamento "imparcial" do tema, ao mesmo tempo em que se esforçavam por revalorizar a figura do veterano como um "traumatizado de guerra", acabavam por "requentar" os mesmos delírios metafísicos de Apocalipse Now. "São filmes que removeram da guerra alguns de seus mais importantes fatores sociais, históricos e políticos e, em seu lugar, apresentaram uma paisagem existencial de violência e morte, resistente à compreensão e vazia de sentidos mais amplos, além da coragem e força norte-americanas. [...]. A experiência norte-americana no
} 
Este diagnóstico é reforçado pelo modo como é figurada a relação entre Barbara Jean e seu público: aproximados pela contiguidade espacial, mas distanciados por uma série de mediações culturais e técnicas (o sistema de segurança do aeroporto, a aparelhagem de som, o púlpito armado no pátio interno, etc.), artista e público têm suas posições enrijecidas como funções de uma transação econômica que se realiza por meio do olhar. Chegando em seu avião particular, a cantora tem sua entrada em cena ofuscada pela passagem de um jato da American Airlines pela área de taxiamento, ocupando, momentaneamente, todo o pano de fundo visual e sonoro. Após cumprimentar as autoridades e celebridades presentes, a estrela favorita de Nashville é escoltada até a tribuna montada para que ela se enderece à cidade. As primeiras palavras de Barbara Jean são de agradecimento pelo espetáculo ensaiado que, aparentemente, tem-se repetido nos seus retornos periódicos: "Obrigada Tennessee Twirlers, obrigada Franklin High School Band; eu acho que vocês, crianças, têm melhorado ano a ano". Do lado de dentro do aeroporto, atrás de uma parede de vidro que separa o pátio interno dos saguões de embarque e desembarque, uma conversa ilumina o sentido econômico da relação de Barbara Jean com seu público:

Wade: E aí, você vem comigo para a cidade ou não?

Sueleen: Ai, Wade, você pode ir sem mim; eu vou esperar porque acho que ela vai cantar.

Wade: Ela? Não, ela não vai cantar. Essa aí só canta por dinheiro. Agora, vamos embora!

Na continuação, a banda e os ruídos no pátio interno fazem silêncio para que a cantora discurse. Diante do esvaziamento da trilha sonora, a voz de Barbara Jean produz um incômodo eco ao final de cada frase,

Vietnã tal como vista no cinema tornou-se uma jornada ao coração das trevas, uma viagem a uma região de selvageria que desafia a explicação. Evidentemente, esta visão é, ao mesmo tempo, um posicionamento e um argumento políticos, que tendem a blindar a guerra da possibilidade de escrutínio por um público popular". PRINCE, Stephen. A New Pot of Gold. p. 335. 
evocando a vastidão do espaço entre ela e a barreira de vidro atrás da qual está seu público. Sentindo o incômodo causado pela falta de reação ao discurso, Haven tenta, inutilmente, "puxar aplausos" dentre aqueles que tiveram o privilégio de estar ao lado da cantora. Esta, porém, ampliou sua audiência e, aproveitando-se da exposição para a câmera de TV, faz comercial de seu show: "Eu e meus meninos estaremos no Opry nesta semana e, como meu avô sempre dizia, se por acaso vocês passarem perto do rio, eu espero que caiam na farra".

É só neste momento, diante da ausência de resposta à sua piada, que a cantora percebe que o seu público efetivo, aquele que parou para vê-la no aeroporto, foi apartado dela. Por conta da barreira que os separa, os fãs de Barbara Jean são condenados a uma surdez e a uma mudez na sua relação com a cantora: eles não podem ouvir a voz que ecoa sobre a superfície de vidro, assim como não podem fazer suas reações chegar à cantora. Porém, se 0 vidro isola o som, ele deixa passar a imagem, e Barbara Jean e seus espectadores experimentam uma proximidade extrema na forma de contemplação visual. Em um gesto de desafio a esta mediação espetacular, a cantora desce do púlpito para se aproximar da barreira de vidro, mas, no caminho, sofre um desmaio repentino que abala toda a organização do evento. Ao mesmo tempo, a porta que divide o palco e a área interna é aberta e o público começa a invadir o pátio das aeronaves, disparando o fim da sequência.

Da reiteração cumulativa de barreiras de vidro - as divisórias que separam as especializações técnicas no estúdio de Haven, a tela widescreen enquadrando o número do coral negro, a tela da câmera de TV e, mais adiante, os para-brisas de automóveis em um engarrafamento - emergem um traço estilístico empregado na composição visual e um diagnóstico político: a profunda e generalizada interposição da forma-mercadoria e suas abstrações na 
vida social ou, parafraseando a tese que abre $A$ Sociedade do Espetáculo, a transformação de tudo o que antes era vivido diretamente em representação ${ }^{97}$.

Hoje, no momento em que a forma-mercadoria se impôs de modo avassalador em todas as áreas da produção cultural, reiterar este diagnóstico na relação de Barbara Jean com seu público talvez soe como uma obviedade. Porém, no caso específico da música caipira nos EUA, a metamorfose do artista em espetáculo e do público em espectador é um processo de ruptura que só se completou no início dos anos 1970, de modo que a sua recuperação simbólica na cena tem o valor cognitivo de registrar, narrativa e visualmente, um problema histórico de primeira ordem.

O momento de constituição de uma aliança entre artistas e o público de música caipira nos EUA são os anos 1920 e 1930; portanto, seu pano de fundo histórico é composto pela Grande Depressão, pelas políticas de inclusão social do New Deal e por um movimento de migração interna sem precedentes, em larga medida responsável pelo rearranjo da estrutura de classes em meados do século XX. Nestes anos de formação, os artistas e, principalmente, o público de música caipira, eram, na sua maioria, migrantes brancos, oriundos da classe trabalhadora rural, desterrados pelas secas periódicas conhecidas como Dust Bowl Droughts e pela Grande Depressão. Às tensões sociais geradas pelo afluxo de desempregados a cidades que já sofriam com o excesso de mão de obra, seguiram-se conflitos análogos entre os valores estéticos que eles traziam consigo e uma emergente cultura de massas ${ }^{98}$.

97 "Toda a vida das sociedades nas quais reinam as modernas condições de produção se apresenta como uma imensa acumulação de espetáculos. Tudo o que era vivido diretamente tornou-se uma representação". DEBORD, Guy. A Sociedade do Espetáculo. Tese 1, p. 13.

98 Por trás da rejeição ao sotaque, à aparência, aos modos, ao trabalho e à música dos migrantes, é possível desencavar o veio de um antagonismo de classe muito mais profundo e antigo, que remonta a meados do século XIX e à Guerra Civil, num momento em que a sociedade norte-americana se dividira entre os que defendiam a conservação do modelo de produção escravagista e baseado no latifúndio e os que procuravam abrir caminho para o desenvolvimento capitalista e baseado na indústria. Esse mesmo antagonismo subterrâneo, que se tornava patente conforme as populações até então isoladas no interior passavam a encarar seus antigos inimigos históricos nas grandes cidades, serviu de "mola propulsora" dos principais 
A música caipira, mais especificamente a relação do músico caipira com seu público, foi um dos campos da cultura em que este antagonismo melhor se expressou. Surgindo numa época em que as políticas de amparo do New Deal prometiam democratizar o acesso ao trabalho para artistas populares desempregados pela Grande Depressão, a música caipira não pôde gozar dos privilégios e incentivos distribuídos a outras áreas da produção cultural. Oriundos da zona rural, os músicos caipiras geralmente não eram instruídos na leitura de partituras, um requisito básico para a sua sindicalização e consequente participação nos programas governamentais de fomento. Excluídos do aparato político-cultural do Estado, esses músicos buscaram proteção social em outras frentes, forjando alianças com o capital publicitário, que começava a explorar as possibilidades comerciais do rádio, e com seu público, que atuava como crítico, divulgador, relações públicas, lobista e, no caso das pequenas cidades sem pontos de venda adequados, como comerciante de suas canções. Esses dois fatores foram determinantes para 0 delineamento de duas características que particularizam o country em relação às demais indústrias culturais: uma capacidade de exprimir, "sem culpa", o caráter mercadológico de sua música e uma relação estreita entre artistas e público ${ }^{99}$.

movimentos no enredo de Vinhas da Ira, o grande "épico da migração", publicado por John Steinbeck em 1939. Pense-se, por exemplo, no famoso capítulo 18, em que a viagem dos Joad chega a um impasse de cuja resolução depende a continuidade do romance: refrescando-se no Rio Colorado antes de cruzar o deserto, a família encontra outros migrantes que, desiludidos com a vida na Califórnia, fazem o caminho inverso, de volta às terras exauridas que haviam deixado. A fala desses migrantes em trajetória inversa desafia os protagonistas a decidir se devem continuar ou voltar, trazendo, no breve relato da vida do migrante na Califórnia, o ódio de classe acumulado em décadas e o desejo de reintegrar-se à sua própria classe: "Where's home?' Tom asked. 'Panhandle, come from near Pampa'. Pa asked, 'Can you make a living there?' 'Nope. But at leas' we can starve to death with folks we know. Won't have a bunch a fellas that hates us to starve with."' ('Onde você mora?', perguntou Tom. 'Panhandle, perto de Pampa'. Pa perguntou: 'E dá para viver por lá?' 'Não. Mas, pelo menos lá a gente pode morrer de fome ao lado de conhecidos nossos e não junto com um bando que nos odeia."') STEINBECK, John. The Grapes of Wrath. p. 240.

99 "Ao contrário dos preservacionistas da classe média, os fãs de música caipira não entendiam o comercialismo e a autenticidade como valores mutuamente excludentes. De fato, o comercialismo funcionava para muitos deles como uma maneira de atribuir um valor estético e social a criações culturais que a elite cultural urbana frequentemente desdenhava. [...]. Esse posicionamento cultural de oposição seria elaborado e refinado durante os anos 1950 como uma crítica à autoridade cultural e às relações de poder nos meios de comunicação de massa, transformando o populismo rural em um elemento identitário para a classe trabalhadora branca e urbana". PECKNOLD, Diane. The Selling Sound. p. 44. 
Os anos 1950 marcam o começo da ascensão do country como uma indústria cultural independente, já não mais relegada à função de simples apêndice da publicidade radiofônica. Concomitantemente ao crescimento de seus negócios, ocorria uma relativa inclusão econômica de seu público por meio da aquisição de bens duráveis. Possuir carro e casa era considerado, na "sociedade de consumo" que substituíra aquela do New Deal, o sinal exterior de uma melhoria das condições de vida dos antigos "esfarrapados" da Grande Migração. A percepção da importância econômica que sua condição de "novos consumidores" Ihes conferia dava a essas grandes porções da classe trabalhadora a coragem para exigir a aceitação cultural de seus valores estéticos e, principalmente, o ânimo para ir às urnas e traduzi-la em uma influência política. Tal papel foi comprovado nas eleições de 1968, quando Nixon construiu sua campanha vitoriosa a partir de uma "maioria" não mais "silenciosa", com uma composição racial e de classe marcadamente branca, trabalhadora, sulista e migrante ${ }^{100}$.

\footnotetext{
${ }^{100}$ Se, tradicionalmente, a imagem do caipira foi usada "pelos interesses econômicos da classe média para denegrir a classe trabalhadora branca sulista [...] e para definir os benefícios da civilização avançada por meio de um contraexemplo negativo", ou ainda, "para desafiar a aceitação generalizada e não questionada da legitimidade da 'modernidade' e do 'progresso'" (HARKINS, Anthony. Hillbilly. p. 4), pode parecer estranho que a classe associada a tal imagem tenha alcançado uma unidade política justamente ao projetar-se, ao mesmo tempo, como a portadora do progresso (a classe que trabalha, enquanto "os outros" protestam) e a conservadora da América mais autêntica (a classe que acredita na vida simples). Segundo Harkins, essa possibilidade de "sintetizar" as contradições entre pré-modernidade e modernidade, "vida simples" e "sociedade de consumo", etc., advém da própria "maleabilidade ideológica e semântica" do conceito do "caipira", "enraizada na sua ambiguidade nuclear como uma representação do 'outro branco' que ao mesmo tempo celebra e denigre o passado americano e a cultura popular dos sulistas montanheses" (HARKINS, Anthony. Hillbilly. p. 220). Notadamente, no momento em que o "caipira" alcançou uma proeminência política, transformando-se na base eleitoral da ascensão da Nova Direita, foi lançado, em 1972, o filme Amargo Pesadelo (Deliverance), de John Boorman, de inspiração aparentemente "liberalconservadora", que praticamente fixou a imagem do caipira na cultura de massas a partir de então, retratando os "homens das montanhas" (hillbillies) como "retardados desajustados e aleijados, como estupradores das terras selvagens do Norte da Georgia que aterrorizam um grupo de quadro canoístas de Atlanta [...] descendo o Rio Cahulawassee antes que toda a região fosse inundada para a construção de uma represa" (HARKINS, Anthony. Hillbilly. p. 206) e induzindo o espectador a desejar, numa aliança emocional com os canoístas, que o progresso e a construção da represa encubram todos os mortos na descida do rio e removam os últimos "caipiras" do lugar, recalcando a consciência da existência desse "outro branco" e transformando a região em um lago calmo e propício a um contato aprazível entre o homem e a natureza domesticada pela civilização.
} 
Estranhamente, o processo de solidificação do country enquanto indústria não foi acompanhado por um reforço da relação estreita entre artistas e público que marcou a música caipira nos seus anos de formação; de fato, como nos ensina Diane Pecknold, a modernização do modo de produzir e distribuir música caipira alterou completamente essa relação: de participante nos rumos artísticos e profissionais de seus músicos favoritos, o público foi rapidamente transformado em mero espectador, em consumidor de uma música industrializada, sobre a qual ele só guardou uma influência estatística. Pecknold vê nesta modificação um dos sintomas locais do colapso mais generalizado da ordem social do New Deal e de sua substituição por uma "sociedade de consumo": no plano geral, também se tratou de substituir a integração política dos sujeitos por meio do trabalho para "incluí-los" como consumidores de espetáculos ${ }^{101}$.

Barbara Jean e seu público fazem parte da primeira geração resultante da nova configuração de classes que se formou a partir da Grande Migração; herdeiros daquele tipo de relação mais estreita que caracterizou os primeiros passos da cultura caipira, eles contemplam, separados pelo aparato espetacular, o desmanche de sua aliança histórica pela modernização country ${ }^{102}$. Ainda inconsciente desta ruptura, a cantora fala para a

\footnotetext{
101 "No final dos anos 1960, a música country era cada vez mais imaginada pelos de fora da indústria como a expressão cultural não coesa de uma fantasmagórica 'maioria silenciosa', composta por norte-americanos brancos e descontentes, oriundos da classe trabalhadora. Lançado pela esquerda na imagem de uma massa ameaçadora [...] e pela direita sob a imagem do homem nobre e comum, o público e o comercialismo da indústria country surgiram como metáforas dominantes para o apelo de uma 'democracia de consumo' e para o colapso do New Deal." PECKNOLD, Diane. The Selling Sound. p. 201.

102 Um dos primeiros sinais de tal modernização foi a adoção de um termo comercial ("Country \& Western Music") com vistas a delimitar um campo para os produtos da música country em relação aos novos gêneros "pop" (como o "rockabilly"), que ameaçam diluí-la no varejão de uma indústria fonográfica em expansão. Este processo teve continuidade na medida em que estes produtos eram uniformizados de modo a alcançar "uma sonoridade mais suave, caracterizada por backing vocals, arranjos de cordas exuberantes e estilos de canto mais burilados. Chamado de 'Nashville Sound', o conjunto dessas mudanças estilísticas aproximou o country da música pop e foi interpretado pela crítica como uma tentativa de atingir um público novo, mais próximo da classe média." PECKNOLD, Diane. The Selling Sound. p. 134. Progressivamente, esse acabamento mais industrial da música caipira direcionada ao mercado de massas, a novidade da "rádio country formatada, a implementação de listas rígidas de reprodução de canções e o fechamento de janelas de oportunidades para artistas locais apoiados pelos fãs-clubes, além da
} 
televisão, sem perceber que o seu público "histórico" foi brutalmente apartado dela pelo esquema de segurança do aeroporto. Se, como sugere Bill C. Malone, a principal função que a música caipira teve para os migrantes desterrados pelas secas e pela Grande Depressão foi a de trazer amparo, encorajamento e até um meio de sobrevivência diante de uma realidade socioeconômica hostil ${ }^{103}$, a solidão de Barbara Jean e a passividade de seu público devem ser vistas como ilustrações, no miúdo, de um custo político estendido a toda uma classe social, um preço cobrado na mudança de qualidade da relação entre a classe e suas formas de identidade cultural, que Wade, o personagem com a lucidez dos desiludidos, definiu acidamente: "Ela? Não, ela não vai cantar. Essa aí só canta por dinheiro. Agora, vamos embora!"

Acreditando poder conciliar sua existência distanciada no meio televisivo com a proximidade dos ouvintes tradicionais de música caipira, Barbara Jean caminha na direção do pátio interno, aparentemente movida por um impulso de compensar a solidão a que o moderno culto de celebridades televisivas a condenou. Porém, no meio do caminho, o desmaio, o primeiro de uma série de colapsos da cantora, reencena, no nível simbólico, a sua incapacidade, mesmo na condição de estrela mais querida de Nashville, de reconectar individualmente aquilo que a modernização e o espetáculo separaram. Por meio desta cena, a narração lança dúvidas sobre a aparente positividade que marca a sequência inteira, trazendo à tona o veio subterrâneo

contínua profissionalização das funções de relações públicas dos artistas", alienaram de uma ação direta na nova e emergente cultura country aquelas porções do público que se identificavam com as formas populares eliminadas. Porém, o canto do cisne da aliança de classes entre cantor e público só soaria em 1970, quando a indústria fixaria de vez o lugar do público como "mercado consumidor", por meio de um gesto simbólico, a saber: "a exclusão dos fãs, em 1970, daquele que era o mais importante evento profissional do country, o Disc Jockey Festival, promovido anualmente pela rádio WSM, de Nashville." PECKNOLD, Diane. The Selling Sound. p. $201-202$.

103 "Conforme a classe trabalhadora sulista lutava para sobreviver, primeiro em uma economia rural hostil e marginal e posteriormente no ambiente operário de uma sociedade urbana não familiar, os seus membros aprendiam que tradição e modernidade não podiam ser facilmente reconciliadas. Neste contexto, a música provou ser um recurso inestimável na transição de uma vida rural para uma vida urbana, servindo, ao mesmo tempo, como uma fonte de sustento e identidade e como um meio de expressão." MALONE, Bill C.. Don't get above your raisin': country music and the southern working class. p. $14-15$. 
de atraso, na forma de esgotamento físico e psíquico, necessário ao tipo de progresso trazido pelo capital fonográfico à cidade.

A continuação do quadro temático explora, em mais uma virada do "olhar narrador", o fracasso da modernização country na tarefa de oferecer condições de realização individual e política aos habitantes da cidade, sublinhando a profunda banalidade a que a vida cotidiana foi condenada no momento em que o espetáculo ocupou e desfigurou os espaços públicos de convivência. A passagem entre uma sequência e outra é sinalizada por uma unidade narrativa intermediária: o encontro de algumas das personagens no estacionamento do aeroporto, onde tomam seus automóveis no retorno à casa. Quatro veículos são enfocados: o Cadillac "do ano" (1974) de Del, brilhando de tão novo; o velho Rambler, de Mr. Green; o pequeno Volkswagen decorado em que se "comprimem" algumas aeromoças e a picape que Wade, funcionário da lanchonete, "improvisou", recortando a lataria de um Chevrolet em mau estado de conservação. Os motoristas se aproximam de seus veículos, abrem a porta aos "caronas" (Triplette, Martha, Tom e Sueleen, respectivamente), dão a partida, manobram bruscamente e arrancam em alta velocidade, em movimentos coreografados, numa sincronia quase perfeita.

Dois pontos chamam a atenção neste começo da sequência: primeiramente, observa-se que a narração enfoca o automóvel, uma mercadoria-chave para se entender a passagem da sociedade fordista à "sociedade de consumo", na medida em que oferece à primeira um modelo de produção industrial (a linha de montagem) e à segunda um signo de mobilidade social ${ }^{104}$. Essa tematização inicial sugere que, a partir deste ponto, serão

${ }^{104}$ Essa interpretação nos é sugerida pela leitura de O Nome da Marca, de Isleide Fontenelle. A autora nos ensina que, no caso específico do McDonald's, seu objeto de estudo, o automóvel teve tanto a função "pedagógica" de oferecer o modelo mais eficiente para se montar sanduíches padronizados e rápidos (o "drive thru" seria uma versão da linha de montagem em que o motorista se transforma no "objeto" que circula sobre a "esteira") quanto a função econômica de abrir o mercado para o escoamento da mercadoria oferecida pela rede de lanchonetes, uma vez que a sua expansão se deu a reboque da abertura de autoestradas por onde circulava a crescente produção de automóveis. No que tange a música country especificamente e a indústria fonográfica em geral, o papel do automóvel também foi marcante: aqui ele foi incorporado como 
examinados os resultados práticos que o desmanche do New Deal e sua substituição por uma sociedade espetacular trouxeram à vida cotidiana. Além disso, os automóveis são utilizados pela narração para caracterizar as personagens, como tipos sociais, dentro de uma estrutura de classes, na qual o modelo, o ano e o estado de conservação de cada um sinalizam o lugar ocupado por seus motoristas na sociedade. Este fato, juntamente com a sincronização coreografada dos movimentos das personagens, antecipa o diagnóstico que a narração fará em seguida: a sociedade espetacular, que se valeu da expansão de bens de consumo para justificar uma presumida superioridade do modo de produção capitalista em relação a outros modelos de organização político-econômica, não foi capaz de eliminar desigualdades sociais, fixando-as, por exemplo, como diferenças na qualidade do acesso à "mercadoria-automóvel"; além disso, nesta sociedade, cujo ritmo é ditado pelas necessidades de valorização do capital, a espontaneidade e a criatividade foram substituídas por uma "coreografia mecânica" de gestos previsíveis. Em outras palavras, o discurso fílmico enuncia, por meio de caracterização e de movimentos coreografados, a única igualdade que o espetáculo pode oferecer: a intensa padronização da vida social.

Numa tomada aberta, agora vemos os carros passar pela cancela do estacionamento, movendo-se do fundo para o primeiro plano da imagem, enquanto, na fachada externa do aeroporto, um enorme letreiro em alto-relevo, no qual se lê "Nashville Airport", ata as duas pontas da primeira parte do quadro, remetendo ao título de abertura e sinalizando seu fechamento. Um "eco visual" é produzido por uma placa ao lado da cancela, na qual se lê "Não Entre", o que inverte o sentido daquele título (em que se lia "Bem-vindo a Nashville"), arrematando a sequência com uma "legenda" e pontuado a sua conclusão. Enquanto isso, no pátio interno, Bill Jenkins narra os últimos acontecimentos para seus telespectadores, o que reforça a ideia de que o

tema, viabilizou produções na condição de patrocinador anunciante e, principalmente, funcionou como "janela de difusão" de música industrializada por meio de seus rádios e, mais tarde, tocafitas, desde os Motorolas instalados em automóveis a partir dos anos 1930. 
discurso televisivo não apenas desdobra o espaço, mas também alonga o tempo de exploração comercial de um assunto, dando ao desmaio de Barbara Jean uma duração extra na reportagem.

De uma tomada fechada sobre o slogan pintado no furgão de Walker ("Novas raízes para a nação"), o "olhar da câmera" nos leva para o meio de uma autoestrada, onde ele persegue três automóveis que avançam, em sincronia perfeita, sobre pistas de rodagem paralelas. Na trilha sonora, Walker emite um discurso defendendo que o hino nacional seja simplificado, obtendo uma resposta extradiegética de um banjo country que, ao tocar "The Star-Spangled Banner" em registro "galhofeiro" e tempo acelerado, o adapta ao gosto que se tornava hegemônico naquela primeira metade dos anos 1970. Na continuação da sequência, um sofá cai do bagageiro de teto de um automóvel, que segue caminho, deixando para trás um rastro de choques e um enorme engarrafamento. Sem alterar o registro e o tempo, o banjo passa do hino nacional para uma música "ligeira", à moda das trilhas dos filmes de "perseguição em autoestrada", enquanto na mixagem são adicionados ruídos espetaculares de batidas, freadas e vidro estilhaçado. O acúmulo de clichês visuais e sonoros retirados do "repertório" do cinema enlatado auxilia a narração na tarefa de reconstruir uma paisagem ideológica familiar, enquanto a frustração da expectativa de uma "cena de ação" - de fato, o engarrafamento, na sua "imobilidade", pode ser encarado como uma "anticena de ação" - em favor de uma sequência analítica, sugere que tais clichês foram refuncionalizados: em vez de se oferecerem como objetos de fruição estética para o espectador, eles funcionam como indícios para o reconhecimento de um problema.

Evidentemente, isso não impede - de fato, até exige que Opal, em um "espelhamento negativo" da posição do espectador, seja representada em uma situação em que o reconhecimento de tal paisagem ideológica resulte em um gozo extático: "É disso que eu preciso para meu documentário! Carros se espatifando, corpos mutilados. Isto é que é a América!", diz a personagem. Esta primeira impressão obedece, com extremo rigor, à 
"lógica" da personagem, traçada anteriormente na cena da gravação do número gospel, que consiste em demonstrar, por meio de suas escolhas, comentários e julgamentos, o tipo de atividade perceptiva que o espectador deve evitar. Sobre a mimese do olhar do "olhar do espectador" na cena, Helene Keyssar nos ensina que:

"Nosso engajamento com o filme é o de 'observador participante'; [...], somos colocados na posição de, ao mesmo tempo, tomar parte e refletir sobre o espetáculo. [...] Nosso ponto de observação é marcadamente similar àquele das personagens na autoestrada. [...] Assim como nós, elas estão separadas do acidente por uma tela; como nós, elas não tiveram controle sobre o acidente. [...]. Isto não quer dizer que nosso olhar não seja privilegiado: as personagens na autoestrada só têm seus próprios recursos para preencher o tempo de espera, enquanto a mobilidade mágica da câmera continua nossa jornada ao redor da cena."105

A consciência dessa vantagem ajuda a desencavar o "gesto" carregado pela avaliação "excitada" de Opal: o de confortar o espectador com uma opinião retirada do senso comum, desobrigando-o de indagar sobre um sentido além da superfície ideológica ostensiva. Porém, se entendermos a personagem como um "exemplo negativo" que a narração oferece para a educação perceptiva do espectador, então a melhor leitura de seu comentário deve ser "Isto é o que não é a América", ou melhor, "Isto é o que se pensa ser a América". Essa "identificação distanciada" com o ponto de vista da personagem - que mimetiza nosso olhar, produzindo identificação, mas o espelha negativamente, criando distanciamento - instaura, no plano discursivo, um "espectador-interlocutor" que deve exigir da narração a capacidade de demonstrar artisticamente aquilo que sua personagem silencia.

A resposta a tal exigência pode ser apreciada a partir da análise dos diferentes níveis de construção da sequência, a começar por sua concepção cênica e dramatúrgica. Do ponto de vista da encenação, o engarrafamento é uma "cena de conjunto", cujos elementos de composição

${ }^{105}$ KEYSSAR, Helene. Robert Altman's America. p. 134 - 135. 
foram dispostos ao longo de um espaço aberto: um trecho interrompido para reformas na Interestadual 65, tendo como pano de fundo a vida cotidiana real o tráfego não bloqueado do outro lado do canteiro central da estrada. Como nos lembra Jan Stuart,

"a cena seria inevitavelmente comparada ao engarrafamento apocalíptico de Weekend à Francesa, de Jean-Luc Godard, embora se tratasse menos de uma homenagem ao cineasta francês do que uma ideia obtida a partir de uma experiência desagradável, vivida pela roteirista Joan Tewkesbury, em sua segunda visita a Nashville."106

Após os choques e o engavetamento causados pelo sofá derrubado na pista, os automóveis que vêm atrás reduzem a velocidade até parar, tornando-se, um a um, a marcação cênica para um pequeno núcleo de duas ou três personagens que, ao somar-se, constituem os fragmentos independentes de um conjunto "fraturado". A figura visual que orienta a decantação do assunto em uma disposição espacial de elementos cênicos é a "forma de mosaico": tanto esta quanto o engarrafamento resultam em imagens estáticas, o que traduz visualmente o tema da imobilidade, porém tensionadas internamente pelas linhas divisórias entre suas partes. Sem uma "ação espinhal", cujo desenvolvimento dê unidade dramática a seus elementos de composição, a cena completa é "craquelada" e resulta da soma, em vez da síntese, de uma série de "fragmentos de ação" que, a despeito de trabalharem para o preenchimento do conjunto, emergem primordialmente em seu valor individual.

Wade disputa posições com os motoristas ao redor de seu carro, enquanto Sueleen se exibe na janela do passageiro; no Volkswagen das aeromoças, Tom conversa com suas fãs enquanto distribui autógrafos; no carro de Linnea, a reação de Opal ao acidente vai do choque à euforia e termina com uma entrevista com um desfecho inesperado; Kenny abandona seu carro quebrado, não sem antes atrair o "olhar narrador" para uma pilha de panfletos de campanha de Walker no banco traseiro, o que estabelece, de partida, uma

${ }^{106}$ STUART, Jan. The Nashville Chronicles. p. 147. 
conexão entre esse personagem e a figura do candidato à presidência; em seu Cadillac 1974, Del ri das comparações que Triplette faz entre o uso político de estrelas hollywoodianas e cantores country; no Rambler de Mr. Green, Martha reclama da falta de rádios de rock em Nashville, enquanto o tio fala sozinho sobre os problemas de saúde da esposa; da janela de sua limusine, Bill negocia uma mesinha em forma de tartaruga com um vendedor ambulante; no carro com seu marido, Albuquerque explica como um sujeito enriqueceu vendendo "matamoscas" e como ela própria espera subir na vida gravando um disco em Nashville; em seu jipe, Haven tem uma discussão acalorada com Pearl sobre a letra correta de uma canção de sucesso; no trailer de Tommy Brown, Opal, agora em movimento pelo cenário, comete uma gafe ao confundir a esposa do cantor com uma empregada; fechando o conjunto, o misterioso "homem do triciclo", que até este ponto só aparecera na lanchonete do aeroporto, caminha por cima dos automóveis empilhados pelo acidente, monta sobre seu veículo de três rodas e segue adiante, deixando o engarrafamento para trás, ao som de "It Don’t Worry Me" ("Não estou nem aí"), uma canção que celebra a alienação emocional e política em relação à sociedade em crise.

A heterogeneidade temática dos fragmentos de ação constituídos dentro e ao redor de cada carro não deve ser vista apenas como um efeito planejado durante a decupagem do argumento em roteiro, mas também e, principalmente, como o resultado artístico de um modo de trabalhar que privilegia a diversidade de contribuições. Como nos conta Jan Stuart, os diálogos na sequência do engarrafamento foram largamente improvisados, de modo que "as instruções de Altman para os atores Ned Beatty e Michael Murphy serviram para todos os demais: 'vocês digam o que quiserem e, quando eu me cansar dos dois, eu corto e passo para outro"'107. Liberando a improvisação dos atores e a colaboração dos operadores de câmera, instruídos a captar tudo o que considerassem de interesse, Altman delegou aos trabalhadores envolvidos na filmagem as funções criativas de seus saberes particulares, quer dizer, a

${ }^{107}$ STUART, Jan. The Nashville Chronicles. p. 153. 
seleção do quê e como captar para os operadores de câmera e a elaboração do texto para $o$ ator.

A despeito de sua multiplicidade temática, esses diálogos improvisados compartilham um mesmo tipo de conflito e a uma mesma incompletude de desenvolvimento. A existência desses traços em comum evidencia a parte da elaboração que coube a Altman, seus roteiristas e montadores, criando uma estrutura em para a improvisação e selecionando porções do material captado. Uma leitura de três exemplos de texto improvisado pelos atores os descobre como fragmentos de "conversa ligeira", marcada, ao mesmo tempo, pela banalidade do assunto e pela irreconciliabilidade das intenções envolvidas. No primeiro, a narração surpreende Bill barganhando com um vendedor ambulante:

Bill: Vinte dólares? Eu te dou cinco.

Vendedor: Você me dá cinco? Eu aceito quinze.

Bill: Você aceita quinze? Eu te dou dez.

No segundo, vemos um trecho da entrevista que Opal faz com Linnea para seu documentário sobre Nashville:

Opal: Hmm... Deixe-me ver. Você tem filhos?

Linnea: Sim, tenho dois, um menino e uma menina.

Opal: E eles pretendem ser cantores como a mamãe deles?

Linnea: Bem... Meus filhos são surdos. Nasceram surdos.

Opal: Meu Deus, que horror!

Linnea: Não, espere um minuto, não é bem assim...

Opal: Que deprimente! 
Linnea: Eu gostaria que você conhecesse o meu filho...

Opal: Não, eu não conseguiria, não conseguiria.

Linnea: Ele tem uma personalidade incrível...

Opal: É muita tristeza!

No terceiro, Pearl e Haven discordam sobre a letra de uma canção de sucesso:

Pearl: Ela se chamava "Wanda Wander".

Haven: Não, essa canção era chamada "Wonder Wanda".

Pearl: Não, era "Wanda Wander's got me bad..."

Haven: (falando a um fã) Não tenho caneta.

Pearl: “...I keep travelling and I'm sad.”

Haven: Não, não. Era "Wonder Wanda's got me bad..."

Pearl: Buddy, meu amigo, como é que era?

Bud: Não sei.

Haven: (para seus fãs) Obrigado, obrigado.

Pearl: Diabo! Era "Wanda Wander".

Haven: Era "Wonder Wanda".

Pearl: "WANDA WANDER".

Haven: "Wonder Wanda".

Pearl: (exaltada) "Wanda Wander" ou "Wonder Wanda", que diferença faz? Pelo menos era uma canção de sucesso!

Como se nota na justaposição dos três fragmentos, os assuntos são variados, mas tratados segundo a mesma nota de banalidade que 
domina a cena completa e cujos primeiros "acordes" foram soados pelo acontecimento que disparou o conjunto: a queda de um sofá no meio da estrada, ou seja, um "ato gratuito" cujo significado reside apenas nas suas consequências e não nas suas motivações. Não há desenvolvimento dramático nos fragmentos; quando a narração os surpreende, o conflito já está instaurado e quando os abandona, ele ainda não se concluiu. A natureza desse conflito é a mesma nos três excertos: não se trata da interação dialética dos contrários encaminhando uma síntese, mas do choque puro e simples de intenções e vontades opostas, sugerindo uma continuação autodestrutiva que pode ser a venda com prejuízo, o silêncio ou uma briga. Em todo caso, quaisquer que fossem os "desenlaces", ficaria evidente o fracasso da forma dialógica na resolução deste tipo de conflito e sua degeneração em "logomaquia" ou, se quisermos utilizar uma expressão corrente no inglês, em "cross purposes", quer dizer, uma disputa entre adversários cuja origem está na incompreensão mútua de suas intenções e vontades. Se entendermos a ação dramática como o desdobramento da palavra em uma atividade, então o conflito que sustenta esses diálogos não engendra ação alguma; em vez disso, ele é absorvido pela estrutura dialógica como o "combustível" de um jogo verbal que se compraz no embate inconsequente e na paixão pela concorrência.

Os espaços entre as unidades isoladas não são vazios: de um lado, eles são preenchidos com o movimento de vendedores e de transeuntes seduzidos pela presença de estrelas country; de outro, eles são "costurados" pelas observações e movimentos de dois "olhares épicos" inseridos na cena. Em princípio, não há interação entre os fragmentos independentes, que permanecem isolados no interior de cada carro enfocado; porém, o rápido surgimento de um comércio ambulante e de curiosos de todo tipo instaura uma comunicação indireta entre eles. Agora, o interior e o exterior de cada carro interagem pela mediação de uma troca libidinal, cujo objeto é a imagem e cujo órgão de satisfação é o olhar: para quem está do lado de fora, os ocupantes ilustres dos veículos compõem um espetáculo que atrai a atenção e excita o desejo de possuir o star favorito, por meio de sua imagem registrada em 
autógrafo ou pela proximidade inesperada de seu corpo; para quem está dentro, o mundo lá fora é um espetáculo de mercadorias, com o sorvete e a cerveja que prometem aplacar o calor do meio-dia, com a tartaruguinha kitsch que se oferece para preencher o vazio do tempo de espera, além de uma gama de objetos prontos a satisfazer outros tantos desejos e necessidades; entre um espaço e outro, a janela retangular do automóvel recupera a figura estilística da barreira de vidro como um enquadramento de uma vida cotidiana sitiada pelo espetáculo. Assim, sem que as personagens o saibam, o seu isolamento e a heterogeneidade de seus pontos de vista são conectados por uma mesma relação de contemplação. Em outras palavras, o mercado põe determinações objetivas nas vidas individuais, mas estas seguem confortadas pela ilusão de se autodeterminarem $^{108}$.

O trabalho de reunião dos fragmentos efetuado pelas atividades comerciais tem continuidade no papel representado pelo "olhar épico" de Opal, tanto na reiteração de sua imagem na tela quanto no seu caminhar entre os carros, produzindo uma tênue "costura interna" para algumas porções da cena. Já a posição distanciada do misterioso "homem do triciclo" "costura" o conjunto a partir de fora, introduzindo no espaço da representação uma ancoragem para a "atividade de ver". Representado ao longo de toda a narrativa como uma figura observadora e pensativa, ele nunca toma parte nas ações principais, mas conecta visualmente episódios e quadros, ao passar com seu triciclo de um para outro, funcionando, portanto, com um "eu-épico, embora sob o disfarce de uma personagem dramática"109. Sua "mudez formal", resultante do fato de o discurso não lhe dar expressão na trilha sonora, força suas reações e

\footnotetext{
108 Tal ilusão se aproxima daquilo que Raymond Williams descreveu como "privatização móvel", quer dizer, "a situação em que cada um vive isolado mas todos compartilham uma diversidade de movimentação e de escolhas que, embora variadas, são determinadas. [...] em seu romance Second Generation, [Williams] havia escolhido a imagem do trânsito de automóveis para dizer essa situação: olhando de fora, o tráfego se move segundo regras comuns que são determinadas e determinantes, mas, no interior de cada carro, as pessoas têm a experiência ilusória de estarem indo exatamente para onde cada uma quer, todos no entanto compartilhando a mesma direção e percebendo-a como privada". CEVASCO, Maria Elisa. Para Ler Raymond Williams. p. 272.

${ }^{109}$ SZONDI, Peter. Teoria do Drama Moderno. p. 68.
} 
"comentários" a se concentrarem no olhar, transformando-o em um "modelo positivo" para a atividade do espectador, que também deve captar, refletir e reunir com os olhos os fragmentos de cenas nas quais ele não pode intervir diretamente por meio da fala.

O trabalho de encenação e dramaturgia que se deduz a partir da análise da sequência do engarrafamento, portanto, consiste na fragmentação da unidade da cena de modo a criar uma representação da vida social como algo construído, resultante de ações humanas. A tradição artística que este tipo de trabalho recupera e desenvolve é a do teatro épico, na qual se alinham experimentos que visam a "esclarecer o público sobre a sociedade e a necessidade de transformá-la", tornando "indispensável dissolver a estrutura rigorosa, o encadeamento causal da ação linear, integrando-a num contexto maior e relativizando-Ihe a posição absoluta"110. Traduzindo em termos práticos, isso significa uma ruptura com o princípio de "organicidade da cena" e sua substituição pela "montagem"; daí o fato de o mosaico ser uma forma tão adequada à tradução visual de seu conceito. Na recepção de uma cena épica como esta de Nashville, o estético e o político são articulados dialeticamente, de modo que as funções de "diversão" (fruição estética) e "instrução" (educação política) não podem ser diluídas uma na outra: o princípio que a norteia é o de que só diverte aquilo que é capaz de produzir conhecimento e a cena só ensina algo na medida em que traduz suas lições em formas estéticas, pois, como nos lembra Brecht ao tratar da linguagem poética em geral, "por mais que possa haver conhecimento em uma poesia, é preciso que esteja inteiramente revertido em poesia"111. Para ser capaz de produzir uma reação política às suas lições, a estética da cena épica precisa ter algo de inacabado, completando-se somente quando o espectador, no momento da recepção, faz uma avaliação conclusiva ou uma síntese intelectual de seus fragmentos, toma partido ou realiza uma ação prática. Por isso mesmo, o modelo social de uma cena épica é o relato que se faz a partir de um acontecimento cotidiano, produzindo para tanto uma

${ }^{110}$ ROSENFELD, Anatol. O Teatro Épico. p. 148. 
representação calculada de agentes e ações visando a uma reação prática ${ }^{112}$. A representação épica também é política na sua produção e adotá-la significa uma tomada de posição no campo da arte: cientes de que os meios de produção "espiritual" também estão encarcerados no "cativeiro de forças produtivas"113 que emperra a emancipação material da humanidade, os artistas engajados na representação épica se colocam do lado dos trabalhadores em geral e se servem de experimentos cênicos e dramatúrgicos como estratégias para organizar-se em seu trabalho e para a viabilizar seu acesso a conhecimentos e meios técnicos necessários à sua realização.

Altman e sua equipe não apenas se valeram dessa tradição, mas também contribuíram para enriquecê-la com o repertório técnico e poético do domínio cinematográfico, mais especificamente com a captação e mixagem das fontes de som na cena a partir do sistema de 8 faixas da Lion's Gate e com uma montagem que estabelece relações dialéticas entre som e imagem. Por meio deste sistema, a equipe pôde

"isolar e enfatizar vozes singulares em cenas barulhentas, separando em canais individuais as fontes que compõem o fluxo do burburinho. Na pósprodução, os editores de som puderam 'peneirar' os vários canais, em um processo que Altman chamava de 'desmixagem.'”114

Sem o sistema da Lion's Gate, que separa as fontes no momento de sua captação, a improvisação dos atores teria sido restringida tecnicamente: em primeiro lugar, suas contribuições não poderiam ter sido gravadas, simultaneamente, por um equipamento de som rudimentar, sem antes ter sido rigorosamente planejadas e exaustivamente ensaiadas, de modo a

\footnotetext{
${ }^{111}$ BRECHT, Bertolt. Teatro de Diversão ou Teatro Pedagógico. in: Teatro Dialético. p. 101.

112 Bertolt Brecht. Cena de Rua: modelo de uma cena de teatro épico. in: Teatro Dialético. p. 141 $-152$.

${ }^{113}$ Parte do título do ensaio em que Iná Camargo Costa esmiúça as reflexões de Brecht a respeito da absorção da arte pelo aparato capitalista e das tarefas políticas que ela suscita. Ver: COSTA, Iná Camargo. Brecht no cativeiro das forças produtivas. in: CEVASCO, Maria Elisa \& OHATA, Milton (org.). Um Crítico na Periferia do Capitalismo. p. 187 - 199. Ver também: BRECHT, Bertolt. The Threepenny Lawsuit. in: SILBERMAN, Marc (ed.). Bertolt Brecht on Film and Radio. p. $147-199$.

${ }^{114}$ CHURNER, Leah. Big Auto Dynamite. Reverse Shot (Online), n. 27.
} 
evitar que possíveis "erros" em um quadro prejudicassem a qualidade do conjunto inteiro; em segundo lugar, a impossibilidade de se captarem fontes sobrepostas em um único boom, com um nível mínimo de definição, teria exigido a separação prévia das falas na concepção dramatúrgica. Como os dois gravadores de oito canais que Jim Webb trouxe para o set captavam as vozes de até sete atores cada um (o oitavo canal era reservado para a mixagem) por meio de microfones de lapela, as possibilidades de se trabalhar o material filmado na edição aumentavam exponencialmente.

"Sid Levin, um dos montadores de Nashville, esclareceu a diferença entre a abordagem de Altman e um estilo 'clássico' de filmagem. Em vez de decupar a cena em planos gerais, médios e próximos, Altman utilizava um número maior de ângulos de enfoque, proporcionando aos atores maior flexibilidade. Altman também trabalhou sem rodar, ele mesmo, várias cenas periféricas e panos de fundo, de modo que Tommy Thompson e Allan Rudolph, seus assistentes de direção, frequentemente criaram 'seu próprio filme' em segundo plano." ${ }^{115}$

Perseguindo esta comparação do método de Altman com as práticas convencionais da indústria do cinema, talvez seja correto afirmar que estas separam rigorosamente planejamento de execução, criando estruturas de cerceamento do improviso; já as práticas desenvolvidas no set de Altman não parecem trabalhar para a eliminação do acaso e sim para criar meios técnicos e organizacionais de captá-lo como material para as fases posteriores de edição e montagem, estendendo a criação, enquanto unidade dialética de elaboração e execução, de pensamento e ato, até os últimos passos do processo de trabalho ${ }^{116}$.

\footnotetext{
${ }^{115}$ PLECKI, Gerard. Robert Altman. p. 129.

${ }^{116}$ A unidade dialética a que nos referimos é a mesma que, na teoria marxista, aparece como os dois momentos distintos e integrados do processo de trabalho: a "prévia-ideação" de uma determinada finalidade na cabeça do trabalhador e sua "exteriorização" em um objeto destinado a tal fim. Como lembra Marx, o trabalho é um processo por meio do qual o homem põe "em movimento as forças naturais de seu corpo [...] a fim de apropriar-se dos recursos da natureza, imprimindo-Ihes forma útil à vida humana. Atuando assim sobre a natureza externa e modificando-a, ao mesmo tempo modifica sua própria natureza. Desenvolve as potencialidades nela adormecidas e submete ao seu domínio o jogo das forças naturais. [...]. Uma aranha executa operações semelhantes às do tecelão, e a abelha supera mais de um arquiteto ao construir sua colmeia. Mas o que distingue o pior arquiteto da melhor abelha é que ele figura na
} 
Em outro contexto e tratando de outro filme, Noel Burch tece comentários que se aplicam também ao caso de Nashville; com o auxílio de sua análise, podemos aferir, com mais precisão, o significado estético e político do modo como Altman incorporou artisticamente elementos imprevistos, que se estendiam dos diálogos improvisados até os riscos de se mover um set inteiro para o meio de uma autoestrada apenas parcialmente interrompida:

"Afrouxando o controle durante as filmagens, abandonando certas prerrogativas ao acaso, o realizador pode, durante a montagem, recuperar cem vezes as prerrogativas perdidas, como se apanhasse o acaso em uma 'armadilha'. O acaso reinou absoluto diante da câmera, através da interpretação mais ou menos improvisada dos atores, a câmera 'fixou' tudo em sequências de dezesseis fotogramas por segundo e, depois, o realizador pôde fazer sua 'escolha' dentre as várias possibilidades de montagem. $O$ fato de as possibilidades serem muitas permite-lhe dominar o acaso, em vez de ser dominado por ele, o que não seria possível se, por exemplo, a cena tivesse sido filmada em um único plano de conjunto."117

Ou seja, as ideias de planejamento e de controle, princípios básicos da organização para o trabalho, não estão ausentes do set de Altman; este não se diferencia da prática cotidiana da indústria por ser um espaço desorganizado ou caótico, mas por dirigir suas ações de controle a outros objetos. Enquanto naquela é a "criatividade excessiva" dos trabalhadores que precisa ser "domada", de modo a assegurar a previsibilidade do retorno do

mente sua construção antes de transformá-la em realidade" (O Capital, livro I, p. 211 - 212). Lukács levou o conceito do trabalho como "objetivação" do homem às últimas consequências, entendendo-a como o fundamento ontológico do "mundo dos homens", quer dizer, da realidade histórico-social. O argumento é o de que "no interior do trabalho a objetivação efetiva a síntese, entre teleologia [a prévia-ideação] e causalidade [as leis naturais objetivas], que funda o ser social enquanto causalidade posta [a nova objetividade, humana e histórica]" (LESSA, Sergio. Mundo dos Homens. p. 75). A concepção da "prévia-ideação" e da "exteriorização/objetivação" como dois pontos de uma unidade dialética dentro do processo de trabalho é o pressuposto para uma teoria marxista do trabalho alienado e de suas consequências para o trabalhador: segundo tal teoria, ao separar elaboração de execução, a produção industrial capitalista rompe uma unidade que é o próprio fundamento ontológico do humano, quer dizer, daquilo que distingue o homem enquanto uma "forma de ser" distinta de outras. Como nos lembra Harry Braverman, com tal ruptura, "a mão e o cérebro tornam-se não apenas separados, mas polos divididos e hostis, de modo que a unidade humana de mão e cérebro resulta no seu contrário, em algo abaixo do nível do humano." BRAVERMAN, Harry. Labor and Monopoly Capital. p. 125.

${ }^{117}$ BURCH, Noel. Práxis do Cinema. p. 138 - 139. 
capital investido, nas ações de Altman e sua equipe, são as próprias condições inadequadas de trabalho e de uma vida cotidiana imune às ações dos sujeitos que se tornam um objeto a ser captado e elaborado pela técnica artística.

Como sugere Burch, o acaso só pode ser dominado se as possibilidades de escolha à disposição do realizador forem aumentadas, o que, em um esquema de trabalho como o de Altman, exige uma produção de material muito mais volumosa do que, efetivamente, será aproveitada na montagem final ${ }^{118}$. De fato, para o desespero dos produtores do filme, os trabalhos resultaram em material suficiente para um filme de 8 horas, razão pela qual se chegou a cogitar em dividi-lo em duas partes editadas de 4 horas cada, Nashville Red e Nashville Blue, a serem exibidas em dias alternados nos cinemas ${ }^{119}$. Embora tal ideia não tenha vingado e o "final cut" a que temos acesso hoje seja de apenas 2 horas e 40 minutos, o fato é que, para gerar todo esse volume de material, o trabalho de Altman cumpriu um papel político que o capital cinematográfico dificilmente conseguiria digerir: a transformação do excedente de horas de trabalho não aproveitado na "mercadoria-filme" em uma forma de inclusão de trabalhadores no processo de trabalho e em um exercício

\footnotetext{
${ }^{118}$ Os próprios artistas tinham conhecimento de que esse aumento do volume da produção, com a consequente utilização de mais horas do trabalho, poderia selar o destino da técnica dentro do aparato hollywoodiano. Analisando o empobrecimento contemporâneo das trilhas sonoras em comparação com o que ele e Altman faziam nos anos 1970, Jim Webb faz a seguinte avaliação: "É muito difícil produzir um som de qualidade hoje em dia quando passamos por tantos arrochos econômicos e os estúdios tentam cortar custos. Poucas pessoas na indústria estão de fato dispostas a assumir os compromissos de pós-produção que a técnica multi-track requer. Hoje em dia, o tempo gasto em pós-produção é cada vez menor e quando você explica que todas as faixas que você convenientemente separou, de modo a ter mais opções criativas, terão de ser reunidas mais uma vez, poucas pessoas querem adotar a técnica, pois isso implicaria um aumento da carga de pós-produção. Muitas pessoas ainda parecem interessadas na técnica, mas quando você começa a explicar o tipo de compromisso que ela requer, elas rapidamente recuam e desistem de usá-la". LoBRUTTO, Vincent (ed.). Sound-on-Film: interviews with creators of film sound. p. 82. Ou seja, nessa entrevista, Webb faz o reconhecimento das limitações impostas pela lógica comercial à atividade artística e revela o sentido político de qualquer técnica produtiva: esta é sempre uma forma de compromisso, uma tomada de posição a favor dos ditames do capital (minimização dos custos e maximização dos lucros) de um lado ou das necessidades do trabalho (inclusão de um número maior de agentes no processo) e da arte (aumento das opções criativas) do outro.

${ }^{119}$ STUART, Jan. The Nashville Chronicles. p. 276.
} 
de envolvimento ativo no processo de sua educação técnica e artística ${ }^{120}$. Em suma, o trabalho de Altman, tal como se deduz a partir da cena do engarrafamento, constitui um esforço de retomar, por meios artísticos, o controle de alguns aspectos da vida cotidiana sob domínio do capital, transformando-os em materiais para a arte e incluindo um grande número de trabalhadores nos processos ativos de criação.

Para avaliarmos como as contribuições improvisadas dos atores foram aproveitadas na fase de montagem, formando constelações com os assuntos tratados na cena e no restante do filme, é importante observálas, novamente, na sua concretude, quer dizer, nos fragmentos de diálogo que passaram ao "final cut". De todos esses fragmentos, talvez aquele que mais ilumina o quadro temático como um todo seja o seguinte excerto, elaborado por Michael Murphy (Triplette) e Ned Beatty (Del):

Triplette: Veja você; o negócio com esse pessoal do country é que eles têm um apelo realmente "de raiz".

Del: Fazer o quê? Eles têm muitos fãs.

Triplette: E são essas as pessoas que elegem o presidente.

${ }^{120}$ Esta é uma das qualidades do trabalho de Altman mais difíceis de quantificar, porém muito fácil de se averiguar. Pense-se, por exemplo, na equipe técnica e artística formada e aperfeiçoada em colaboração com Altman, presente em praticamente todos os seus filmes produzidos ao longo dos anos 1970. Pense-se também em um ator como Tim Robbins que, após "se educar" atuando em O Jogador (The Player, 1992), Short Cuts - Cenas da Vida (Short Cuts, 1993) e Prêt-à-Porter (idem, 1994), daria continuidade, na sua carreira de diretor, às pesquisas formais do próprio Altman. (A compreensão das relações entre a obra de Tim Robbins e o trabalho de Altman é facilitada pela leitura de duas dissertações de mestrado: BRANCO, Neyde Figueira. O Poder Vai Dançar de Tim Robbins; ROSA, Joyce. A Espetacularização da Política em Bob Roberts). Entretanto, como nos conta Jan Stuart, a introdução deste método de trabalho produziu atritos ocasionais entre Altman e alguns atores que, ou desacostumados dos processos criativos ou esperando que Nashville lhes servisse de "catapulta para o estrelato", se ressentiram da forma como suas falas eram editadas. Tal foi o caso, por exemplo, de Barbara Harris, a atriz por trás de Albuquerque, que teria ficado "chocada" ao ver o resultado de suas improvisações no engarrafamento, oferecendo pagar que elas fossem refilmadas. A resposta de Altman é reproduzida no livro de Jan Stuart: "Eu disse então a ela, 'Barbara, tudo o que você fez ficou excelente. Eu adorei tudo o que conseguimos extrair de você e não tenho a intenção de mudar nada. Além disso, não há a menor chance de você pagar para armarmos toda aquela situação outra vez. Nós estávamos filmando dez histórias diferentes, ao mesmo tempo, sob um calor de quarenta graus'. O que ela estava me pedindo era impossível." The Nashville Chronicles. p. 163. 
Del: Pode deixar que nós vamos fazer tudo o que estiver ao nosso alcance.

Triplette: Veja só; a gente junta um monte de estrelas de cinema, mas aí as pessoas por aqui acham que elas são excêntricas, loucas... comunistas. (risos)

Del: (risos)

Triplette: (rindo) Muitas delas são mesmo.

Del: (rindo) Bem, é o que contam por aí.

Esse diálogo ocorre dentro do espaço fechado do automóvel de Del, suspendendo certos constrangimentos de verossimilhança e permitindo que os personagens revelem muito mais sobre si do que o fariam em público $^{121}$. Essa privacidade acarreta uma mudança de função em Triplette, que passa de porta-voz da campanha de Walker à expressão de sua "consciência política", exibindo um posicionamento de classe com o qual o candidato, em seu discurso "radical" destinado à totalidade do eleitorado, evita se comprometer. Essa tomada de posição toca, indiretamente, nos pressupostos históricos da própria "operação ideológica" de Walker, a saber: o sequestro do discurso radical, seguido de seu esvaziamento político e de sua mobilização como ferramenta de marketing político endereçada a todas as classes votantes. $O$ traço inequívoco desse posicionamento é o riso.

Como nos ensina a teoria freudiana dos "chistes", as "risadinhas" causadas por gracejos como os de Triplette proporcionam uma

${ }^{121}$ No debate que se seguiu a uma palestra sobre a insuficiência da forma dramática, Iná Camargo Costa esclarece, em linguagem informal e acessível, as vantagens expositivas de cenas em que as personagens conversam em um espaço fechado: "As pessoas estão reunidas num espaço fechado qualquer, por qualquer acaso da vida, e dali não saem. Lá conversam sobre tudo e todos, sem nenhum tipo de censura, e é quando a coisa fica divertida. Por exemplo, na peça que o Tapa encenou, não faz muito tempo, Major Bárbara, o fabricante de armas fala tudo o que alguém precisa saber sobre a relação de um fabricante de armas com o mundo. Em outra formulação: é o discurso da indústria bélica que não se assume, segundo Bernard Shaw, que não tem mais compromisso com a verossimilhança porque ele já é um passo adiante nesses experimentos. Ele confina os personagens e faz os personagens dizerem o que não diriam na 
descarga de prazer agressivo para quem ri, baixando certas inibições do superego e exprimindo, indiretamente, hostilidade e distanciamento em relação ao objeto do riso. Há uma interessante sobreposição aqui entre o conceito psicanalítico de "suspensão das inibições" e o conceito crítico de "suspensão da verossimilhança", ambos agindo, respectivamente, no nível da história e do discurso, como válvula de escape para o "inconsciente político" dos dois personagens, Del e Triplette, entre os quais o riso compartilhado alinhavou uma tomada de posição contra um alvo em comum. Freud nos esclarece o modo como este alinhamento é criado:

"Um chiste nos permite explorar no inimigo algo de ridículo que não poderíamos tratar aberta ou conscientemente, devido a obstáculos no caminho; ainda uma vez, o chiste evitará as restrições e abrirá fontes de prazer que se tinham tornado inacessíveis. Ele ademais subornará o ouvinte com sua produção de prazer, fazendo com que ele se alinhe conosco sem uma investigação mais detida." ${ }^{122}$

Quando Triplette qualifica, em meio a risadas, os atores de cinema politicamente engajados como "loucos", "excêntricos" e "comunistas", ele os ataca e os distancia; com tal gesto, ele demarca, em negativo, o lugar que ocupa, junto com seu candidato, no espectro político, qual seja, uma posição antagônica a tudo o que se considera fora dos padrões da sanidade, do centro aceito das coisas e daquilo que se associa à esquerda mais atuante. Em outras palavras, o personagem revela que o "radicalismo" de Walker nada mais é do que uma colagem produzida pelo marketing político a partir de fragmentos de discurso sequestrados do repertório de diferentes tendências, de modo a vestir com roupagem nova um posicionamento político essencialmente conservador e tradicional.

O fio que se puxa a partir de improvisações como a de Michael Murphy e Ned Beatty corre por uma trama de bifurcações múltiplas que, por um lado, convidam à aventura da descoberta desdobrada em saídas

vida real." COSTA, Iná Camargo. Contra o Drama. Palestra apresentada no Núcleo 2, Cia Fábrica São Paulo, em 12/09/2005.

${ }^{122}$ FREUD, Sigmund. Os Chistes e a Sua Relação com o Inconsciente. p. 103. 
que dão em outras saídas, mas, por outro, ameaçam transformar o discurso crítico em uma narrativa truncada, digressiva e prolixa. Entretanto, mesmo correndo todos esses riscos, é preciso abrir um parêntese na progressão da análise para tratar da autoria, da edição e da inserção do discurso de Walker na cena, sem o quê não seria possível compreender por que aquele diálogo traz à tona os pressupostos históricos de uma figura como Walker.

A fala de Hal Phillip Walker que ouvimos em diversos momentos do filme a partir de seu carro de campanha é uma montagem de fragmentos de um único discurso de 18 minutos, composto e gravado pelo romancista e roteirista Thomas Hal Phillips, amigo pessoal de Altman, nos estúdios Woodland de Nashville. Nascido em 1922, numa comunidade rural do estado do Mississippi, Phillips, que emprestaria seu nome ao personagem, crescera durante a Grande Depressão, fortemente inclinado ao programa do Partido Democrata e às políticas de Franklin Delano Roosevelt. Sua família, entretanto, era de republicanos tradicionais; seu irmão, Rubel, fundou o Partido Republicano do Mississippi e se candidatou ao governo do estado nas eleições de 1963, empregando o "democrata" Phillips como o autor de seus discursos de campanha. Quando Altman o incumbiu de elaborar o texto e dar voz a seu personagem, liberando-o para escrever aquilo que acreditava ser um bom discurso para um candidato à presidência, é de se imaginar que Thomas Hal Phillips trouxesse para essa tarefa toda a bagagem contraditória de sua formação política e produzisse um exemplo

"clássico de populismo selvagem, enquadrado por um aforismo do Velho Testamento ('Guias cegos, que filtrais um mosquito e engolis um camelo') tão apreciado pelos residentes de Kossuth [a cidade natal de Phillips] que bem poderia ter sido escrito lá. Nele, Phillips antecipou, com alegria estrondosa, a fobia a advogados que logo tomaria conta dos clubes de comédia, quando não do país inteiro ('Um advogado é treinado para fazer duas coisas e duas coisas apenas. Para esclarecer...eis a primeira...e para confundir'). Ele bajulava a mídia e provocava os ricos. Ele acertava, sem exibir um posicionamento claro, no assunto polêmico das drogas alucinógenas. Ele encenava a quinta-essência do drama de 
espelhos e cortinas de fumaça, parecendo dizer tudo, ao mesmo tempo em que não dizia nada." ${ }^{123}$

Portanto, o discurso que sequestra elementos de populismo à direita e à esquerda, transformando-os no "pseudorradicalismo" de um candidato que oferece seu Partido da Substituição como uma alternativa ao jogo político tradicional, em parte se deve à formação contraditória de seu autor (criança da Grande Depressão, admirador do New Deal de Roosevelt, filho de imigrantes húngaros conservadores, empregado de uma campanha do Partido Republicano) e à liberdade criativa recebida para expressá-la em texto. A outra parte vem do trabalho de edição e montagem realizado por Altman e sua equipe de som, quebrando o discurso de 18 minutos em inúmeras "citações", inseridas em pontos-chave na ordem que convinha à narração, de modo a fazer o personagem "dizer tudo e dizer nada". De novo, o que chama a atenção é o aspecto colaborativo e livremente criativo nas várias fases do trabalho, desde 0 texto de Phillips, passando por sua atuação como a voz de Walker até os últimos passos da montagem entre imagem e som.

Voltando ao diálogo entre Del e Triplette, talvez agora fique mais fácil compreender como ele traz à tona os pressupostos históricos de figuras políticas como Walker. Além de fixar um posicionamento para o candidato cuja estratégia eleitoral é "deslizar" entre direita e esquerda, a referência ao "comunismo" na indústria do cinema ("Muitas delas são [comunistas] mesmo", diz Triplette) indiretamente traz, para o plano consciente da obra, um trauma histórico que a ideologia conservadora gostaria de manter reprimido, a saber: o ataque que o senador Joseph Raymond McCarthy e sua famigerada comissão de inquérito (HUAC) perpetraram contra o trabalho sindicalizado dentro de Hollywood, sob a desculpa de investigar e punir atividades "antiamericanas"124. Tais ataques, que puseram o aparato de

\footnotetext{
${ }^{123}$ STUART, Jan. The Nashville Chronicles. p. 71.

${ }^{124}$ Embora a ideologia tenha permitido que parte desse trauma passasse distorcida como uma disputa entre caçadores de bruxas de um lado e os "Hollywood Ten", a lista negra de "comunistas infiltrados", do outro, os objetivos e os alvos dos ataques macartistas eram bem mais amplos: "Dalton Trumbo, um dos 'Hollywood Ten', identificou três razões para as
} 
vigilância e repressão do Estado a serviço do capital e contra os trabalhadores culturais, com o objetivo de romper elos de solidariedade de classe e de ação política coletiva, que reuniam desde grevistas ocupando fábricas nos últimos anos da década de 1940, passando por roteiristas sindicalizados e chegando ao panteão de Hollywood, constituem um dos pressupostos para a emergência de figuras ambíguas como Walker no final dos anos $1960^{125}$. O outro pressuposto é a existência de uma vasta porção da classe trabalhadora, deslocada pela Grande Migração, que não se sentia representada pelas estruturas de classe do proletariado urbano, encontrando "consolo" em um tipo de música que a direção cultural do Partido Comunista, e das organizações de esquerda ligadas a ele, sempre desdenharam.

São os dividendos políticos resultantes da ascensão econômica dessa classe excluída da representação que estimulam a cobiça de Triplette, evidenciada na descrição da importância que o "pessoal do country" ganhou no processo eleitoral contemporâneo: "o negócio com esse pessoal do

investigações do HUAC: a destruição dos sindicatos, a paralisação das ações políticas antifascistas e a remoção de conteúdos progressistas dos filmes". BROE, Dennis. Film Noir, American Workers, and Postwar Hollywood. p. 37. É interessante notar que Michael Murphy, após interpretar uma figura que distancia com o riso os dolorosos acontecimentos resultantes das perseguições macartistas, viveria, logo em seguida, um roteirista que perde o emprego pela inclusão na lista do HUAC em Testa de Ferro Por Acaso (The Front, 1976), de Martin Ritt.

${ }^{125}$ Sobre a solidariedade de classe atacada por HUAC, veja-se a seguinte citação reproduzida por Dennis Broe: "Os trabalhadores de Hollywood [incluindo os escritores] falam sempre da indústria e nunca do meio cinematográfico, pois, para eles, trabalhadores de cinema são puramente trabalhadores industriais'". Film Noir, American Workers, and Postwar Hollywood. p. 37. O livro de Broe é uma história materialista do filme noir, indispensável para se entender os ataques de HUAC ao trabalho e suas repercussões na produção cinematográfica. A tese de Broe é a de que o fim da Segunda Guerra tornou redundante o New Deal enquanto "pacto de guerra" entre capital e trabalho, criando um novo cenário para a luta de classes no pós-guerra e uma desculpa para os ataques estatais por meio do HUAC. Neste processo, o trabalhador, até então acolhido na ordem política do New Deal, passa a ser visto como um "comunista infiltrado". Broe acredita que este processo histórico é captado na forma do filme de detetive, cujo herói já era, havia algum tempo, uma figura da classe trabalhadora, modificando sua função: em vez de ser um agente da ordem, o herói se torna uma figura problemática, perseguida pela polícia e pelo capital, constantemente angustiada pela possibilidade de ser enquadrada, ou pelo aparato repressivo do Estado ou pela burocracia das novas formas de trabalho que se erguem no pósguerra. Em outras palavras, o herói do filme de detetive se metamorfoseia no herói do filme noir. A respeito do impacto que a Segunda Guerra e a ruptura do New Deal tiveram sobre a produção cinematográfica e a estética do filme noir, ver também: ARTHUR, Paul. The Gun in the Briefcase; or, the Inscription of Class in Film Noir. in: JAMES, David E. \& BERG, Rick. The Hidden Foundation. p. $90-113$ e BODNAR, John. War and Peace at Home. in: Blue-collar Hollywood. p. $87-132$. 
country é que eles têm um apelo realmente "de raiz". [...]. E são essas as pessoas que elegem o presidente". Como sempre ocorre na História, lá onde a esquerda hesita, por conta de escrúpulos estéticos, a direita avança e prospera. E assim, a representação da classe trabalhadora, em parte desorganizada pelos ataques de HUAC e em parte desdenhada pelas instituições culturais associadas ao Partido Comunista, pôde ser "usurpada" pelos oportunistas de plantão e transformada em um espetáculo atraente para as massas no final dos anos $1960^{126}$.

Essas alusões improvisadas a acontecimentos que tornaram a representação da classe trabalhadora "historicamente disponível" para a direita ascendente no início dos anos 1970 formam uma constelação com outros elementos da cena, resultando em potencial cognitivo para o espectador. Na medida em que uma das funções da sequência do engarrafamento é figurar a sociedade norte-americana do pós-guerra como uma "sociedade do espetáculo", a referência ao processo que criou as condições para que a direita, inimiga histórica e declarada da classe trabalhadora organizada, passasse a anunciar-se como representante de seus interesses, toca na operação política fundadora do espetáculo em geral e, especialmente, de sua versão norteamericana, a saber: a "usurpação" da experiência política direta e sua transformação em representação, em espetáculo, em algo a ser contemplado ${ }^{127}$.

\footnotetext{
${ }^{126} \mathrm{Na}$ verdade, como nos conta Iná Camargo Costa, o processo de desmanche das estruturas culturais da classe trabalhadora é anterior ao macartismo, o que faz imaginar que o New Deal tinha muito mais afinidades com o senador McCarthy do que normalmente se pensa: "O Red Scare (ameaça vermelha) foi instaurado como programa governamental durante a primeira guerra, constituindo-se na mais extensa, intensa e brutal perseguição pública e privada, da história americana, ao movimento operário. A pretexto de combater pacifistas (principal bandeira da IWW), a iniciativa tratou de matar e deportar militantes e de destruir tudo o que fosse imprensa, instituição cultural e social de trabalhadores com a mais remota inclinação para a dissidência". Panorama do Rio Vermelho. p. 33.

${ }_{127}$ O termo "usurpação da representação" é sugerido por Iná Camargo Costa, em um debate sobre as relações entre o teatro pós-dramático e a sociedade do espetáculo, como uma descrição mais adequada do processo político de constituição da sociedade do espetáculo do que o termo corrente "crise de representação". Usando este termo como viés crítico, Iná faz um resumo, aparentemente do capítulo "O proletariado como sujeito e como representação" de $A$ Sociedade do Espetáculo, retraçando o processo de desmanche das estruturas de ação política direta da classe trabalhadora organizada e sua "usurpação" por uma classe de "representantes", donde o termo "espetáculo", "representação", que Debord vai adotar. Os primeiros momentos dessa transformação do sujeito histórico em representação foram a vitória do bolchevismo sobre
} 
Assim, no diálogo improvisado por Michael Murphy e Ned Beatty, o sentido reprimido no termo "substituição", que compõe o nome do "Replacement Party" de Walker, é dialeticamente revirado pela montagem e "ressignificado" na "consciência política" da obra como um efetivo "Partido da Usurpação".

Tendo visto, no miúdo do texto de um fragmento de diálogo, o modo como a técnica de montagem de Altman libera a improvisação e contribui para a criação de uma cena épica, é preciso voltar para o quadro mais amplo, reunindo os dados que levantamos até aqui, de modo a verificar como esta mesma técnica faz a cena "contar" algo, quer dizer, como recursos poéticos e técnicos do repertório do cinema transformam dramaturgia e encenação em narrativa. Partindo da definição sintética de narrativa como um "discurso fechado

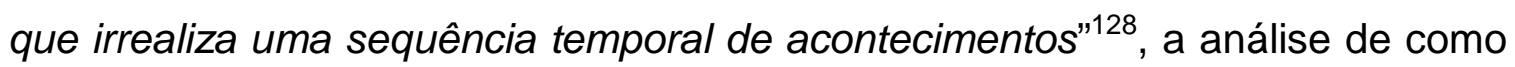
o discurso fílmico define um foco narrativo, quer dizer, um ponto de vista em relação ao narrado, pela decomposição de acontecimentos em recortes espaciais (enquadramentos) e durações (planos) e por sua recomposição em linhas de desenvolvimento divergentes da linearidade cronológica do tempo empírico, pode nos ajudar a entender as operações narrativas envolvidas na sequência do engarrafamento.

A linearidade do tempo empírico é a "ancoragem", o ponto de referência de todos os tempos "irrealizados" pela sequência; dela se deduz a primeira temporalidade da sequência: aquela da disposição horizontal dos enunciados discursivos. Com início e fim claramente identificáveis (pontuados, respectivamente, pela queda do sofá que dispara os choques entre os carros e pela canção "It don't worry me"), o tempo do discurso dura a

os conselhos de trabalhadores durante a Revolução Russa e a condução da luta operária pelo reformismo da social-democracia. Os passos seguintes foram dados com a ascensão do nazifascismo na Europa e do New Deal nos EUA, este último desembocando no seu próprio desmanche pelo macartismo e na moderníssima "Sociedade do Espetáculo" norte-americana dos anos 1960 em diante. O debate em que Iná expõe tais argumentos ("Teatro Épico e Teatro Pós-Dramático na Sociedade do Espetáculo") está disponível em vídeo em http://vimeo.com/5752431, consultado em 14/11/2012.

${ }_{128}$ METZ, Christian. Apontamentos para uma Fenomenologia da Narração. in: A Significação no Cinema. p. 42. 
quantidade de minutos necessária à exibição da sequência na tela de cinema ${ }^{129}$. Ou seja, é uma duração curta, que "passa rápido", mas que compacta, ou "irrealiza", como diria Metz, outra bem mais alongada: o tempo vivido pelas personagens na história. A possibilidade de manipular o tempo empírico para que ele "caiba" na sequência pressupõe a técnica fílmica, que o decompõe em "fragmentos de instantes" (planos), para depois remontá-lo com a sugestão de elipses entre uma unidade e outra, ou seja, figurando uma duração temporal na história mais longa do que a soma de suas partes expressas no discurso.

Essas elipses são facilmente identificáveis: os diálogos são apresentados in media res, abandonados antes de se concluírem e, em alguns casos, retomados em uma etapa posterior, exigindo que o espectador preencha com a imaginação aqueles espaços (elipses temporais) não representados. O próprio abandono da cena pelo "olhar da câmera" antes da dispersão do engarrafamento sugere que as conversas dentro de cada carro se alongam na história para muito além daquele trecho que o discurso nos apresentou. Emerge, assim, entre o tempo do discurso e o tempo vivido pelas personagens um conjunto de relações gerais: ambos seguem na mesma direção (para frente) e cumprem a mesma trajetória (linear), o que evidencia a determinação do primeiro sobre o segundo na "narração em tempo presente" adotada no cinema; aquele é claramente objetivo e mensurável, não podendo sofrer alterações em sua duração, ordem ou frequência na recepção normal do filme em salas de cinema, enquanto o desenrolar dos conflitos vividos entre as personagens cria, para seu ponto de vista, a ilusão de uma experiência subjetiva

\footnotetext{
${ }^{129}$ Embora a organização temporal mais profunda do cinema se avizinhe àquela da tradição do romance, no seu nível mais superficial, ela está mais próxima daquela que caracteriza 0 espetáculo dramático. Isso porque, assim como no drama e diferente da literatura, o tempo da recepção do espetáculo fílmico ou dramático é objetivo e não controlado pelo espectador. $\mathrm{Na}$ recepção da narrativa literária, por outro lado, esse tempo é também subjetivo; é o tempo vivido do leitor, na medida em que este pode acelerar e reduzir o ritmo de leitura, parar e retomar o texto mais tarde, avançar parágrafos, voltar uma página, concentrar-se em uma frase, repeti-la, etc. Esse "ato de leitura, em que se funda a autonomia sui generis do tempo do discurso, ato que é uma travessia não apenas espacial mas também temporal do texto, no sentido do encadeamento do significado das frases, possibilita igualmente a flexibilidade do tempo da narrativa ficcional ou épica. O leitor nunca é servo do texto, assim como o espectador o é do drama que presencia". NUNES, Benedito. O Tempo na Narrativa. p. 46.
} 
do tempo; o tempo empírico deduzido da trajetória da apresentação discursiva é uma sucessão contínua de instantes, enquanto aquele vivido pelas personagens é apresentado como uma justaposição descontinuada de fragmentos sem nexos causais entre si.

Ao redor e sobre a "vivência" das personagens, há ainda uma segunda temporalidade da história que o discurso evoca pela ação combinada de dois dispositivos formais: o desenrolar das atividades comerciais em torno dos carros e a transmissão da fala de Walker a partir do furgão de campanha, ambos criando, por conta de sua onipresença, respectivamente na imagem e na trilha sonora, uma sensação de "tempo circular" que tudo abarca, movendo-se sem sair do lugar. Este segundo nível de arranjo temporal se opõe ao anterior, sugerindo outro grupo de relações: enquanto o tempo é vivido pelas personagens como uma experiência subjetiva, movendo-se de acordo com a interação das forças de suas intenções conflitantes, o tempo combinado do mercado e da política espetacular tem a objetividade do "tempo das coisas", independente das vontades individuais; enquanto aquele emana dos sujeitos em imitação ao tempo empírico, o "tempo da natureza", este os transcende e os controla na condição de "tempo da segunda natureza".

A figura mediadora entre estes dois tempos é o trabalho. De fato, embora a superfície da cena reproduza a ideologia de que a "sociedade de consumo" democratizou o gozo do tempo livre, no seu avesso dialético a análise narrativa descobre a repressão do gozo por meio da extensão do tempo de trabalho. Invertendo o caminho percorrido por Walter Benjamin no ensaio em que define a arte de narrar como o resultado de uma acumulação multissecular de saberes oriundos do trabalho artesanal ${ }^{130}$, talvez seja possível pensar a sequência do engarrafamento como um "inventário" e uma sedimentação das formas e condições das relações de produção na sociedade do espetáculo.

${ }^{130}$ BENJAMIN, Walter Benjamin. O narrador: considerações sobre a obra de Nikolai Leskov. in: Magia e Técnica, Arte e Política. p. $197-221$. 
Em diferentes níveis de aproveitamento, o trabalho é tematizado, representado e sedimentado nas formas que organizam as relações temporais da sequência: ele é o "tema oculto" da conversa que toca no macarthismo e resvala na repressão ao trabalho, ação fundadora da versão norte-americana da sociedade do espetáculo; ele aparece também na sua versão cristalizada pela ideologia, como o meio para o "sonho americano", na conversa entre Albuquerque e Star sobre um "self-made man" que enriqueceu produzindo e vendendo mata-moscas; ele é representado em formas ostensivas (a atividade de ambulantes), indiretas (as entrevistas de Opal, a distribuição de panfletos de campanha) ou veladas (o trabalho de relações públicas disfarçado pela distribuição de autógrafos), que permitem avaliá-lo como precário (o caminhar embaixo do sol do meio-dia e no meio dos perigos da estrada), sem planejamento (a entrevista feita ad hoc), monótono (a expressão de enfado de Haven ao dar autógrafos), serializado (Tom repetindo o gesto de anotar os telefones de suas fãs) e injusto (a negociação com o vendedor ambulante que baixa o preço de sua mercadoria em mais de $50 \%$ ). O processo de trabalho na sociedade do espetáculo oferece ainda a lógica temporal para a organização narrativa das atividades que envolvem as personagens e das interações dentro dos carros, permitindo contrapor as excitações que o consumo oferece ao olhar à banalidade e à monotonia da vida individual ${ }^{131}$. Em suma, o trabalho funciona como "figura mediadora" entre a obra e a matéria histórica, oferecendo formas de organização temporal por meio das quais a imposição generalizada da lógica da produção repetitiva e seriada de relações sociais pode ser figurada como um arranjo narrativo no qual o tempo vivido pelas personagens é sitiado pelo tempo da circulação das coisas $^{132}$.

\footnotetext{
${ }^{131}$ Aqui, o arranjo formal da narrativa coincide com a crítica do espetáculo feita por Debord, pois, tal como na sequência, a "análise de Debord se apoia sobre a experiência cotidiana do empobrecimento da vida vivida, de sua fragmentação em esferas crescentemente separadas, assim como da perda de todo aspecto unitário na sociedade. O espetáculo consiste na recomposição dos aspectos separados sobre o plano da imagem. Tudo aquilo que falta à vida se re-encontra neste conjunto de representações que é o espetáculo." JAPPE, Anselm. Guy Debord. p. $22-23$

${ }_{132}$ Essa análise da figuração do trabalho nos tempos narrados é tributária, ainda que em negativo, do polêmico ensaio em que Lukács exalta os escritores realistas que adotaram a
} 
Finalmente, sobrepondo-se ao tempo discursivo e aos dois tempos figurados, há ainda um quarto nível de organização temporal que se deduz da direção, do ritmo e da trajetória dos movimentos realizados pelo "olhar narrador" ao redor e dentro da cena, decompondo seu objeto em planos e enquadramentos e recompondo-o na montagem. Tentar descrever a forma desses movimentos nos ajuda a delinear o foco narrativo na sequência, o que talvez seja facilitado pelo fato de que a montagem aqui não se pauta pela construção de um "olhar natural", portanto, não se esforça para apagar o trabalho de narração. Não obstante esse distanciamento claro em relação à prática industrial corriqueira, talvez valha a pena listar as prescrições estéticas da "decupagem clássica" de cenas de conjunto, pois, a partir delas, poderemos deduzir, em negativo, as estratégias adotadas para recortar e montar 0 engarrafamento. Quem nos auxilia nesta tarefa é Jean-Claude Bernardet, que resumiu da seguinte maneira o receituário oferecido pela indústria para se "contar histórias sem ferir a sacrossanta impressão de realidade":

"Não cortar de um plano muito aberto para outro fechado, ou vice-versa, pois o espectador sentiria o choque, mas ter transições suaves, progredir aos poucos para planos maiores ou menores. Não cortar de um plano parado para outro em movimento, mas cortar de parado para parado, ou do movimento para o movimento. No corte em movimento, que se tenha a impressão de que o movimento de segundo plano dá prosseguimento ao plano anterior. [...]. Obtém-se um ritmo cuja fluência vai levando o espectador, que fica com a impressão de assistir a um fluxo contínuo e não se dá conta de estar vendo uma sucessão de planos que duram pouco mais de alguns segundos. Não jogar de chofre o espectador numa situação ou ambiente novo, mas familiarizá-lo primeiro com planos relativamente abertos, fazê-lo penetrar aos poucos na ação, quando então os planos irão se fechando, e abrir novamente quando a ação estiver se encerrando e antes de passar para outra. Evitar que a câmara ocupe

narração para representar a fase gloriosa do capitalismo ascendente e execra os naturalistas que figuraram, por meio da descrição, a fase doente do sistema, já encaminhando para o imperialismo e a Primeira Guerra. LUKÁCS, Georg. Narrar ou Descrever. in: Ensaios Sobre Literatura. p. 43 - 94. Antonio Candido fez reparos imprescindíveis ao argumento lukacsiano ao afirmar que "num romance naturalista, materialista por pressuposto, a descrição assume importância fundamental, não a modo de enquadramento ou complemento, mas de instituição da narrativa". CANDIDO, Antonio. Degradação do Espaço. in: O Discurso e a Cidade. p. 65. Em uma fase inicial de nossa pesquisa, tivemos a oportunidade de publicar um artigo em que analisamos a sequência do engarrafamento à luz dos argumentos de Lukács e Candido. Ver: 
posições que na vida cotidiana seriam pouco usuais, o que pode ocorrer com ângulos acentuados de câmara alta ou baixa. Se usar câmara alta ou baixa no meio da ação, que a posição da câmara seja de preferência justificada pela posição de um personagem, que seja um ponto de vista. [...]. Disfarça-se dessa forma a intervenção do cineasta, a presença do narrador."133

Tendo como referência a descrição de Bernardet, é possível medir o quanto a decupagem espacial e temporal da sequência pôde se desembaraçar dos parâmetros industriais da produção cinematográfica. Para começar, a técnica de captação e mixagem de som da Lion's Gate permitiu a criação de um "supercampo" sonoro, formando um "burburinho" que atuou como elemento de coesão do conjunto, suspendendo a necessidade cognitiva e narrativa do "establishing shot" e liberando a decupagem por meio de planos de durações, orientações e tamanhos variados ${ }^{134}$. Desobrigada de percorrer uma trajetória preestabelecida na direção do objeto, a montagem pôde saltar de planos abertos, que abarcam dois núcleos simultâneos, para planos próximos dentro dos carros, e desses para tomadas que colocam o "olhar da câmera" ao lado da janela do motorista ou do para-brisa, em uma ordem ditada apenas por sua "curiosidade investigativa". O mesmo vale para a orientação das tomadas, cuja variação constante desenha um foco narrativo distanciado, quer dizer, que não se cola a nenhum olhar interno, e móvel, pois não se fixa nem fora nem

ALEIXO, Antonio Marcos. Reflexões sobre a configuração do espaço fílmico em Nashville. Revista CROP, São Paulo, n. 13, p. 139 - 152, 2008.

${ }_{133}$ BERNARDET, Jean-Claude. O Que é Cinema. p. 42 - 43.

134 O termo "supercampo", um "extracampo" mais rico, adensado pela mixagem de fontes sobrepostas, é de Michel Chion, assim como também é do autor a afirmação de que aquilo "que o supercampo do cinema multi-track tem feito é progressivamente modificar a estrutura de edição e construção da cena. Durante muito tempo a construção cênica baseou-se no 'establishing shot'. Com isso eu quero dizer que, na edição, o plano que mostrava o cenário completo era um elemento estratégico com grande importância dramática e visual, pois, colocado no começo, no meio ou no fim da cena, ele forçosamente trazia (estabelecendo ou restabelecendo) o espaço ambiente, e ao mesmo tempo reapresentava os personagens no quadro, criando uma ressonância particular no momento de sua intervenção." CHION, Michel. Audio-Vision. p. 150. Com efeito, a criação de coesão por meio da trilha sonora não era novidade na carreira de Altman, devendo seus experimentos em Nashville ser encarados como "a consumação de uma técnica que Altman já havia posto em funcionamento nos anúncios públicos transmitidos por rádio em $M A S H$, passando pelos boletins radiofônicos de Voar É Com Os Pássaros [Brewster McCloud] e a onipresença dos programas de rádio em Renegados Até a Última Rajada [Thieves Like Us], a saber: a utilização de ruídos mediados como personagem e 
dentro da cena, afastando-se quando necessário e "rompendo" a barreira de vidro das janelas para ver e ouvir de perto.

Essa montagem que alterna entre intervalos breves e longos, por meio de planos com durações variadas, bem como entre níveis de exigência de concentração, passando de densos planos de conjunto, de "leitura" mais lenta, para outros próximos, percorridos rapidamente, cria um ritmo para o movimento do foco narrativo e, por conseguinte, para a apreensão intelectual da sequência. $O$ "olhar narrador" age livremente sobre os conteúdos narrados; ele não observa passivamente o fluir do tempo das personagens e das coisas, mas os joga uns contra os outros, criando simultaneidades na imagem (por exemplo, entre a venda de sorvetes no primeiro plano e a conversa entre Opal e Linnea no segundo) e na trilha sonora. É desses movimentos realizados pelo foco narrativo que se deduz a quarta organização temporal da sequência; por ser 0 tempo com o qual o "olhar narrador" cria uma estrutura de recepção para a sequência, ele pode ser descrito como o "tempo do pensamento"; por percorrer uma trajetória não linear, que se move ao ritmo de saltos para frente e para trás, acelerações e alongamentos, que manipula as temporalidades da história, permitindo que as contradições entre a circulação das coisas e a vivência das personagens sejam captadas na forma narrativa e apreendidas intelectualmente pelo espectador, o tempo que o movimento do "olhar narrador" descreve é o "tempo do pensamento dialético"135.

Quando apreende uma categoria determinante da vida empírica, tal como é o tempo, e a domina com meios poéticos e técnicos, a

como cola auditiva que reúne os elementos visuais do filme." STUART, Jan. The Nashville Chronicles. p. 144.

${ }^{135}$ As seguintes afirmações de Brecht sobre a necessidade de o teatro adequar o tempo da representação ao tempo do pensamento valem também como um desafio para o cinema: "Parte da transformação social do teatro é que o espectador não deve ser tratado no modo usual. $O$ teatro não é mais o lugar onde seu interesse é despertado, mas aonde ele o leva para ser satisfeito. Logo, nossas ideias de tempo têm de ser revisadas para o teatro épico. Processos mentais, por exemplo, exigem um tempo diferente de processos emocionais e não necessariamente se adaptam ao mesmo tipo de aceleração". BRECHT, Bertolt. The question of criteria for judging acting (Notes to Mann ist Mann). in: WILLETT, John (ed.). Brecht on Theatre. p. 55 
arte de Altman e seus colaboradores ganha o valor de atividade modelar que descongela e antecipa o possível, trazendo uma implicação política clara: se até o tempo pode ser apreendido, dominado e adequado às necessidades humanas, por que não o poderia a realidade social e histórica? ${ }^{136}$ De fato, talvez seja por resultar numa imagem da realidade sócio-histórica como algo contraditório, mediado por um foco narrativo e passível de controle, que os recursos técnicos e poéticos aplicados nesta sequência contribuíram, no campo específico do cinema, para o avanço da representação épico-dialética.

Tendo analisado em detalhe as características formais do engarrafamento enquanto concepção cênica, dramatúrgica e narrativa, é possível sugerir uma hipótese sobre o modo como a equipe de Altman encarou o desafio de figurar a intensificação e a degradação do trabalho como o avesso dialético da "sociedade de consumo". Tal figuração começa pelo reconhecimento da paisagem ideológica da sociedade enquanto espaço concorrencial, onde o gozo e a "liberdade" são viabilizados pela relação estética com a mercadoria, ou seja, pela redução da multiplicidade sensível do corpo ao órgão da visão e da gama de objetos passíveis de satisfazer o desejo às imagens valorizadas em oferta no mercado. A concorrência é figurada na cena em todos os níveis de sua composição, podendo ser recuperada em uma linha de desenvolvimento que vai do particular ao geral ou vice-versa: na estrada, os carros concorrem por espaço e se chocam; no seu interior, as intenções das personagens colidem em vez de concatenar-se em uma estrutura dialógica que faça a ação avançar; no entorno dos carros, as personagens demarcam um

\footnotetext{
136 "A arte não possui em si, sem qualquer mediação, o espaço, o tempo e a causalidade, nem se mantém [...] como esfera ideal muito além das suas determinações; influenciam-na como que de longe e imediatamente se tornam nela algo de diverso. [...]. Além disso, as categorias formativas da arte não são, sem mais, qualitativamente diferentes das categorias externas, mas transpõem a sua qualidade para o medium qualitativamente diverso, apesar da sua modificação. Se essas formas são na existência externa as formas determinantes da dominação natural, são, por sua vez, dominadas na arte; lida-se com elas livremente. Através da dominação do dominante, a arte revê profundamente a dominação da natureza. A utilização dessas formas e da sua relação com os materiais torna evidente o seu caráter arbitrário, perante a aparência de inelutabilidade, que lhes cabe na realidade. Se uma música comprime o tempo, se um quadro redobra o espaço, concretiza-se a possibilidade de conseguir algo diverso." ADORNO, Theodor W. Teoria Estética. p. 159.
} 
espaço e buscam protegê-lo da ação perigosa dos "outros"; na decupagem, os fragmentos da cena se alternam, disputando o tempo de exibição; na mixagem, as fontes de som se sobrepõem, enquanto buscam destacar-se em relação às demais. Em todos estes níveis, portanto, o engarrafamento nos oferece uma expressão reconhecível de uma ideologia segundo a qual

"os indivíduos se constroem em permanente confronto com a estrutura social global e com os outros indivíduos, numa dinâmica de disputas pelas quais cada individualidade, ao se constituir enquanto egoísta e competitiva, constrói também uma sociedade desumana, concorrencial. Nessa forma de sociabilidade cada indivíduo tem na sociedade e nos outros indivíduos uma oportunidade ou obstáculo para acumular capital, e uma expressão da generalidade humana. Temos aqui, em sua essência, o individualismo burguês, de um lado, e a sociedade civil burguesa, de outro."137

Se esta ideologia naturaliza a competição e o enfrentamento como deduções lógicas do egoísmo "natural" do indivíduo burguês, ela precisa elevar o mercado, a arena de disputas, à condição de instância "política" capaz de efetuar a síntese dos antagonismos sociais em uma sociedade pacífica. Segundo este modo de ver, a troca mercantil, ao transformar o antagonismo das posições contraditórias entre os sujeitos em diferenças objetivas entre os produtos de seus trabalhos, ofereceria a forma mais "aperfeiçoada" para se mediar conflitos, emergindo, a um só tempo, como o "ponto máximo" do desenvolvimento material e político da humanidade.

"Nesse sentido, mercado e democracia burguesa estão indissoluvelmente articulados. O primeiro é o espaço da concorrência econômica; o segundo, o lugar da disputa política, na concepção liberal burguesa." ${ }^{138}$

A utopia do liberalismo consiste justamente em criar uma sobreposição tão perfeita entre estas duas esferas que o sujeito possa, alternadamente, fazer do consumo um ato político, uma expressão da liberdade na escolha desta ou daquela mercadoria, e da experiência política uma oportunidade de consumo, fruindo esteticamente programas, imagens e

${ }^{137}$ LESSA, Sergio. Para Compreender a Ontologia de Lukács. p. 129. 
celebridades políticas. A sequência do engarrafamento dá uma forma reconhecível à superfície ideológica do liberalismo, sugerindo na organização espacial de seus elementos que a atividade mercantil, com suas imagens atraentes e seu burburinho onipresente, atua como uma força de coesão entre as tensões e fraturas do espaço narrativo, fazendo-o emergir como a representação de um espaço social onde o gozo é uma ilusão palpável, materializada em imagens, e onde os sinais do fracasso da modernização (a interrupção do tráfego, a inversão da mobilidade oferecida pelo automóvel) podem ser rapidamente transformados em elos da reprodução social (a conversão do engarrafamento em uma espécie de drive-in ao ar livre). Em outras palavras, neste primeiro polo da figuração prismática adotada na sequência, o que se evoca é a própria ideologia do espetáculo, a ilusão de uma "positividade indiscutível e inacessível" que esta sociedade conta de si e para si, como autoproteção e mascaramento da consciência de suas falhas; são seus princípios epistemológicos, estéticos e morais, que a fala "sem réplica" do espetáculo condensa em um "mantra" e repete ad nauseam: "o que aparece é bom, o que é bom aparece"”139.

Por outro lado, como lembra Guy Debord, a capacidade que o mercado (um dos significados de "espetáculo") tem de efetuar a síntese das individualidades conflitantes em uma totalidade harmônica é uma utopia cuja realização o espetáculo não poderia permitir, sem colocar em risco o pressuposto de sua própria existência: a sociedade dividida em classes. Exploração do trabalho, representação e concorrência são três fundamentos da divisão de classes sem os quais não se conservam a sociedade espetacular e o mercado. Assim, a coesão trazida pelo espetáculo é precária e só pode existir até o limite da reprodução normal da sociedade dividida.

"A origem do espetáculo é a perda da unidade do mundo, e a expansão gigantesca do espetáculo moderno revela a totalidade dessa perda: a abstração de todo trabalho particular e a abstração geral da produção como um todo se traduzem

${ }^{138}$ LESSA, Sergio. Para Compreender a Ontologia de Lukács. p. 134. 
perfeitamente no espetáculo, cujo modo de ser concreto é justamente a abstração. No espetáculo, uma parte do mundo se representa diante do mundo e lhe é superior. O espetáculo nada mais é que a linguagem comum dessa separação. O que liga os espectadores é apenas uma ligação irreversível com o próprio centro que os mantém isolados. O espetáculo reúne o separado, mas o reúne como separado."140

A tese de Debord descreve, com absoluta justeza, o polo negativo da sociedade do espetáculo figurado na sequência do engarrafamento. A despeito dos elementos de coesão visual e sonora utilizados, a imagem que se evoca é fraturada e tensionada. Se, como nos ensina Richard Sennett, a circulação sanguínea ofereceu uma forma visual para o sonho de Adam Smith de um "mercado livre, de trabalho e mercadorias, operando de modo parecido à circulação do sangue" e um modelo de planejamento aos construtores e reformadores do século XVIII, que adequaram os espaços urbanos às necessidades de mobilidade do capitalismo ascendente, "imaginando uma cidade de artérias e veias contínuas, por meio das quais os habitantes pudessem se transportar tais quais hemácias e leucócitos no plasma saudável"141, então a imagem oferecida pela sequência de Nashville, com seus choques entre automóveis, a interrupção do fluxo e a representação da vida imóvel dentro dos carros parados, pode ser lida como o diagnóstico da doença terminal de uma sociedade esclerosada. Nesta sociedade em crise, o mercado só pode ganhar sobrevida aumentando as oportunidades de reprodução do capital, o que ele faz sitiando a vida cotidiana onde quer que ela ocorra, transformando as atividades mais banais em elos de sua reprodução e estendendo a duração do tempo de trabalho.

Figura-se, assim, um novo estágio da relação espacial da cidade com o mercado: não mais restrito a uma região dedicada às transações econômicas, ele agora se impõe em todos os palcos da vida social, cumprindo assim uma das etapas finais da jornada histórica que a forma-

${ }^{139}$ DEBORD, Guy. A Sociedade do Espetáculo. Tese 12. p. 16 - 17.

${ }^{140}$ Ibid., Tese 29. p. 23.

${ }^{141}$ SENNETT, Richard. Carne e Pedra. p. 261 e 262 - 263. 
mercadoria realiza, das bordas para o centro do processo social, deixando um rastro de desagregação no próprio tecido da sociedade. Dialeticamente, o "isolamento e a atomização" produzidos nesta trajetória são, ao mesmo tempo, realidade e ilusão; realidade porque as personagens estão efetivamente sós dentro de seus carros e apartadas de seus interlocutores por conta do antagonismo da relação existente entre eles; ilusão porque foram reunidas em um mesmo processo econômico mediado por tal relação antagônica.

"Essa atomização do indivíduo é, portanto, apenas o reflexo na consciência de que as 'leis naturais' da produção capitalista abarcaram o conjunto das manifestações vitais da sociedade, de que - pela primeira vez na história - toda a sociedade está submetida, ou pelo menos tende, a um processo econômico uniforme, e de que o destino de todos os membros da sociedade é movido por leis também uniformes."142

Essa uniformidade do processo econômico é traduzida na sequência como uma homogeneidade de gestos, temas e do tempo vivido pelas personagens. A mesma banalidade, a mesma serialização e a mesma ação violenta de choques sucessivos experimentados no trabalho em geral são reencontradas na forma de conversas banais, repetitivas e, em alguns casos, violentamente conflituosas. Essa imagem de um tecido social esgarçado desmascara a mentira contida na promessa do gozo por meio do consumo e revela que o "espetáculo é o sonho mau da sociedade moderna aprisionada, que só expressa afinal o seu desejo de dormir. O espetáculo é o guarda desse sono." 143

Em suma, após mapear, nas imagens atraentes produzidas pela mídia televisiva e pela modernização country do Aeroporto Metropolitano de Nashville, aquilo que Debord chama de "manifestação superficial mais esmagadora" do espetáculo, a narração vai encontrar, na sequência do engarrafamento, o fundamento material da sociedade espetacular: a violência de um processo de trabalho que rompe a unidade da práxis vital para

142 LUKÁCS, Georg. História e Consciência de Classe. p. 208.

${ }^{143}$ DEBORD, Guy. A Sociedade do Espetáculo. p. 19, tese 21. 
plasmá-la em representações nas quais os sujeitos não se reconhecem. Com isso, é possível compreender a necessidade lógica e expositiva da canção que fecha o quadro temático, sublinhando o profundo sentimento de alienação que caracteriza os sujeitos produzidos pela sociedade sitiada pelo espetáculo:

"Dizem que este trem não dá carona,

mas não estou nem aí.

E que o mundo inteiro está tomando partido,

mas não estou nem aí.

A economia está deprimida; eu, não.

O meu astral está o mais elevado possível.

Você pode dizer que eu não sou livre,

mas não estou nem aí."144

144 "They say this train don't give out rides,/ but it don't worry me./ And all the world is taking sides,/ but it don't worry me./ Economy's depressed, not me./ My spirit's high as it can be./ Andy you may say that I ain't free,/ but it don't worry me". 


\section{4: o funcionamento da máquina}

Contra a crença arraigada de que a arte com uma "tendência política" explícita geralmente é caracterizada por uma realização estética insuficiente, Walter Benjamin argumenta que não se mede a inclinação política de uma obra a partir do modo como ela se posiciona face "às relações de produção da época" e sim como "se situa dentro dessas relações." ${ }^{145} \mathrm{Na}$ visada crítica de Benjamin, ficam invalidadas as formulações dicotômicas que opõem forma e conteúdo, acusando a obra política de combinar a tendência progressista de seus conteúdos com uma forma conservadora, e vice-versa. Para fugir deste tipo de "armadilha teórica", Benjamin propõe a validação da "técnica produtiva" como uma categoria da análise política, pois é justamente a técnica que faz a mediação entre a obra e as relações de produção de seu tempo.

$\mathrm{Na}$ medida em que se esforça por fazer um levantamento de intervenções técnicas responsáveis pela inclinação política progressista de Nashville, o presente estudo precisa delinear as relações de produção cinematográficas dentro das quais o filme se situa. Entretanto, por tratar de uma indústria cultural em particular, a da música country, e, indiretamente, das próprias indústrias do cinema e da música em seu conjunto, Nashville não é apenas uma obra inserida nas relações de produção de sua época, mas também, em larga medida, uma reflexão sobre elas. Essa "duplicidade de posicionamento" de um filme, que é parte de seu próprio objeto de crítica, coloca um desafio para a análise política de sua narrativa, que deverá averiguar se as observações expressas em seus conteúdos e na sua forma narrativa são confirmadas ou desmentidas pelas soluções técnicas que vimos apontando até aqui. Na medida em que mapeiam o funcionamento da indústria fonográfica em Nashville e constroem um ponto de vista sobre um tema político

${ }^{145}$ BENJAMIN, Walter. O Autor Como Produtor. in: Magia e Técnica, Arte e Política. p. 122. 
(o assassinato como ação política), os quadros temáticos justapostos entre o engarrafamento na autoestrada e o último show de Barbara Jean oferecem um material vasto para a análise deste posicionamento duplo. O presente capítulo se ocupa destes quadros temáticos.

A primeira tomada do conjunto inteiro se liga à sequência do engarrafamento por meio de uma "ponte sonora": o trecho do discurso de Walker interrompido na autoestrada se completa num espaço distante daquele, conforme o furgão de onde ele é emitido passa na rua que se vê através da janela de um quarto de hospital. A paciente deste quarto é Barbara Jean, socorrida após o desmaio no aeroporto. A cena faz um comentário indireto à rotina de Loretta Lynn, cantora country que serviu de modelo para a personagem, e suas internações por conta de uma carga de trabalho excessiva ${ }^{146}$. Ambas stars

“são o 'ganha-pão' de um séquito de empresários e agentes: amarradas por contratos impiedosos, arrastadas de cidade em cidade, elas se esgotam tentando manter um ritmo de vida delirante. Quando não estão na estrada, elas assombram as clínicas privadas." $147^{147}$

Ao redor da personagem, o discurso narrativo dispõe uma série de atividades periféricas da produção musical: stars menores que buscam aumentar seu valor de mercado com homenagens ou visitas à cantora, Triplette, o empresário que insiste em contratá-la e a imprensa que se esforça para conseguir uma foto ou uma entrevista. No meio da movimentação, os serviços médicos tentam trabalhar: uma enfermeira se aproxima de Barnett, marido e empresário de Barbara Jean, e dá uma notícia que só ele ouve. Um plano enfático do rosto da cantora revela uma fisionomia apreensiva.

\footnotetext{
146 Joan Tewkesbury, a roteirista de Nashville, explica que a ideia de representar Barbara Jean como uma cantora frágil e inconstante veio após assistir a um show de Loretta Lynn, que a impressionou pelo "contraste entre sua baixa estatura e enorme disciplina. 'Foi uma das coisas mais excitantes que eu já vi na minha vida. E naquela ocasião eu descobri uma informação muito importante: Loretta Lynn passa muito tempo no hospital. Eu perguntei por quê, e eles disseram: ela trabalha demais"'. Apud STUART, Jan. The Nashville Chronicles. p. 56.

${ }^{147}$ HENRY, Michael. Altmanscope (sur le plateau de "Nashville"). p. 13.
} 
O furgão de Walker passando do lado de fora do quarto configura um segundo espaço cênico e transforma a moldura da janela em um enquadramento aberto dentro da tela de cinema. O recurso já foi utilizado em cenas anteriores e será reiterado na continuação do filme: o outdoor em que se lê "The Bank" no fundo de um dos primeiros planos diegéticos; a barreira de vidro que separa o número gospel no estúdio de gravação; o aparelho de TV ligado no quarto de Tom; o televisor colocado sobre uma toalha no meio do Centennial Park, etc. O efeito que o traço estilístico traz para esta cena específica é o de "epicização", quer dizer, de relativização do problema encenado (a hospitalização de Barbara Jean), mostrando que, do lado de fora, há mais acontecimentos pedindo a atenção do espectador ${ }^{148}$. Com isso, a encenação épica vem de encontro a outros recursos técnicos e formais que multiplicam nossos objetos de observação, exigindo que façamos uma seleção dos materiais que nos são oferecidos.

Em um corte abrupto, o foco narrativo salta para uma via próxima à autoestrada. Caminhando pelo acostamento, Kenny, o violinista que abandonara seu carro quebrado no meio do engarrafamento, e Albuquerque, a principiante que fugira do marido para tentar uma carreira em Nashville, conversam sobre seus planos, enquanto tentam conseguir uma carona que os leve até a cidade.

"Albuquerque [...] explica que ela planeja tornar-se 'uma cantora country \& western ou uma estrela', adicionando, em um tom prosaico, que sublinha a permutabilidade das duas profissões, que, se o estrelato não der certo, 'eu posso tentar uma carreira em vendas'. Mais tarde, quando tenta conseguir que alguém ouça sua fita demo, ela recusa a oferta amistosa de uma cerveja com um sucinto 'não obrigada, estou aqui a negócios'. Albuquerque sabe bem o que é o negócio da música comercial e o abraça com alegria e

\footnotetext{
${ }^{148}$ Trata-se do desenvolvimento, com a técnica cinematográfica, de um recurso épico introduzido no teatro pela peça Interior (1894), de Maurice Maeterlinck. Nesta peça, conforme a cena é dividida em dois espaços opostos, "o corpo dramático se cinde em duas partes", retratando "a separação entre sujeito e objeto que está posta no fatalismo de Maeterlinck e leva à reificação do homem. [...]. Em Interior, a épica dissimulada da matéria [...] constitui a cena como uma autêntica situação narrativa na qual sujeito e objeto se contrapõem." SZONDI, Peter. Teoria do Drama Moderno. p. 73 - 75.
} 
ingenuidade, em vez de cinismo [...] e, como uma prova da bênção ocasional que torna o sonho de Nashville tão atraente, ela, de fato, ganha sua grande chance no final do filme."149

A imagem dos dois jovens chegando à cidade, um carregando um instrumento associado à música caipira tradicional (o "fiddle", violino caipira), a outra com sonhos de estrelato na música country, ativa no espectador uma "quadro de leitura" recorrente na cultura norte-americana: a história do migrante tentando realizar o "Sonho Americano". Por mais que a ideologia do "Sonho Americano" tenha sido reduzida a um clichê da indústria do cinema, ela encontra, na vibrante Nashville dos anos 1970, certo grau de sustentação. À época do lançamento do filme, um jornalista do New York Times expressou as possibilidades que a cidade oferecia afirmando que, em Nashville, "você salta do ônibus carregando um violão e, com um pouco de sorte, em dois anos você tem uma piscina em formato de violão"'150. De fato, o número de negócios realizados na cidade à época dava uma palpabilidade a tais anseios de ascensão social. A partir deste ponto, o movimento crítico realizado pelo foco narrativo será o de percorrer, metaforicamente, a distância entre "saltar de um ônibus com um violão" e "ser dono de uma piscina em formado de violão", explorando aquilo a que o jornalista chamava de "um pouco de sorte". As trajetórias de Kenny e Albuquerque são excelentes balizas para se avaliar este espaço entre promessa e realização do sonho, mas também o são as trajetórias de outras personagens enfocadas neste grupo temático.

O próximo objeto dessas focalizações é mais uma aspirante ao estrelato: Sueleen Gay, a balconista da lanchonete do aeroporto. Diante da penteadeira, em seu quarto minúsculo, ela ensaia uma canção que compôs para uma "noite de amadores" no bar Deemen's Den. De modo irônico, a narração pontua o despreparo técnico e artístico da personagem: o figurino é excessivo, a música é mal feita, a voz é excessivamente nasal e desafinada. Em outras palavras, as chances de Sueleen passar do "subemprego" (o trabalho amador) para uma posição de destaque na indústria country são tão incertas

${ }^{149}$ PECKNOLD, Diane. The Selling Sound. p. 229. 
quanto as de Albuquerque e Kenny. Na justaposição das cenas, a narração constrói um diagnóstico e lança uma pergunta: a cidade da música atrai um grande número de principiantes, mas estará disposta a absorvê-los todos?

Embora este conjunto de sequências sem conexão interna (apenas cortes abruptos entre uma e outra) não pareça formar um núcleo temático, uma olhada mais atenta descobre a construção de um argumento. A montagem que relaciona o olhar apreensivo de Barbara Jean a respeito de um diagnóstico médico com a descrição de três personagens que poderiam vir a substituí-la revela a força objetiva de um esquema de produção que se conserva transformando sujeitos em peças intercambiáveis de seu funcionamento. A doença de Barbara Jean pode causar um contratempo, mas nunca um abalo definitivo em um aparato que produz tantos amadores sonhando com uma chance de trabalhar.

O mapeamento dos amadores subempregados, ávidos pelo acesso ao profissionalismo, continua no quadro temático seguinte, em que a passagem por dois espaços de música ao vivo sugere consequências políticas da concorrência entre principiantes. Embora o trabalho amador guarde uma memória da relação colaborativa que caracterizou a cultura country "prémoderna", o momento mapeado pelo ponto de vista narrativo é o de uma completa incorporação industrial dos músicos amadores na condição de "repostos do sistema", ou, para usar o termo crítico marxista, de um "exército de reserva".

O primeiro plano de uma placa luminosa identifica um clube noturno e o tipo de música a que se dedica: "Old Time Picking Parlor", "Bluegrass Music". Baseado em instrumentos acústicos como violão, bandolim, dobro e violino, o "bluegrass" é um subgênero do country, uma espécie de "música caipira de raiz", assentada numa base de ritmos tradicionais britânicos e na incorporação posterior de influências afro-americanas, mormente do jazz. No

${ }^{150}$ Apud PECKNOLD, Diane. The Selling Sound. p. 22. 
palco, uma banda folclórica, os Misty Mountain Boys, apresenta um número com a tradicional forma "bluegrass": "Rio Mississippi, continue fluindo/ Empurre suas águas barrentas para o mar/ Me sinto tão solitário rolando rio abaixo/ Velho Rio Mississippi, me leve para casa". ${ }^{151}$ O clube está lotado e todas as mesas ocupadas, o que obriga Kenny a sentar-se junto de Bill e Mary, o casal de cantores famosos que assistem ao show. Kenny pede licença, em tom servil, e não parece ouvir um comentário maldoso de Mary: "Ele parece com o Howdy Doody".

Em outro ponto da cidade, Bud Hamilton leva Martha ao Deemen's Den, uma espécie de bar para músicos principiantes. Sueleen, a amadora que vimos ensaiando diante do espelho, aguarda no balcão a sua vez de tentar a sorte. Enquanto isso, Sheilla e Patty, as Smokey Mountain Laurels, se apresentam acompanhadas pelo violão de Frog, o músico que fora demitido por Haven na sequência dos estúdios. A dupla consegue desempenhar satisfatoriamente a canção composta por Ronee Blakley, atriz que interpreta Barbara Jean. A forma musical e o canto recuperam a tradição "bluegrass" e a letra exalta a conversão religiosa (o batismo) como consolo para uma vida de trabalho duro e de renúncia do desejo:

\section{"Oh, esses tempos atribulados têm-me aborrecido. \\ Minha labuta e minhas lágrimas me deixem triste. \\ Oh, esses tempos atribulados têm-me aborrecido.}

Mas o Senhor é o melhor amigo que tenho.

Então descendo até o rio, dou um beijo de adeus em meus pecados.

Vou descendo até o rio, de onde sairei novinha em folha.

\footnotetext{
151 "Mississippi River, keep on flowing/ Push your muddy waters down to the sea/ I'm so lonely, rolling on this river/ Old Man Mississippi River carry me home".
} 
O bom Jesus veio de manhã sem beijar mulher à noite..."152

De volta ao Old Time Picking Parlor, Lady Pearl, a proprietária, faz um pronunciamento: "Temos uma grande estrela na plateia nesta noite; Tommy Brown voltou à cidade". O cantor se levanta para agradecer pelos aplausos, mas a excitação geral se transforma em tensão quando Wade, o garçom negro da lanchonete do aeroporto, proclama: "Tommy Brown? Tommy Brown é o preto mais branco da cidade!" Pressentindo o começo de uma confusão, o cantor famoso faz menção de retirar-se, observado de perto por Kenny. Haven Hamilton o acompanha, contemporizando: "Esse tipo de coisa não é comum no bar de Lady Pearl. Não é comum em Nashville. Eu espero que você diga isso aos outros". Continuando seu desabafo, Wade tenta barrar a saída a Tommy Brown, mas é interceptado no caminho por Kenny, a quem desfere um golpe violento, derrubando-o por cima de uma mesa. No palco, Lady Pearl ameaça, mostrando dois revólveres (de brinquedo?) em um cinturão: "Escutem aqui mocinhos, eu trago duas armas aqui!"

No Deemen's Den, chegou a hora de Sueleen cantar. A canção escolhida é "Let $\mathrm{Me} \mathrm{Be}$ The One", de sua autoria ${ }^{153}$. Conforme a amadora se arrisca, desafinadamente, na primeira estrofe, a voz de uma das principiantes que acabaram de se apresentar sentencia, fora do campo: "Que horrível!" Sem notar a presença de Star, o marido que a vem perseguindo, Albuquerque passa pelo balcão à procura de Frog, com quem espera gravar um "disco demo". A confusão causada por sua fuga, tão logo se dá conta da presença de seu perseguidor, é sincronizada pela narração com os versos de Sueleen, produzindo um comentário irônico: "Todo mundo precisa receber amor, todo mundo precisa dar também"154. Toca o telefone de Trout, o gerente do bar

\footnotetext{
152 "Oh, these troubled times, they've been making me weary./ All my toil and teardrops make me sad./ Oh, these troubled times, they've been making me weary./ Still the Lord is the best friend I have./ So I'm going down to the river, where I'm going to kiss my sins away./ I'm going down to the river, where I'm going to begin brand-new today./ Sweet Jesus, he came in the morning, he didn't kiss no women at night..."

${ }^{153} \mathrm{Na}$ verdade, o autor da canção, propositalmente ruim, é Richard Baskin, diretor musical do filme e ator que interpreta Frog.

154 "Everybody needs some tender loving, everybody needs to give some, too".
} 
e mestre de cerimônias na noite de calouros. É Triplette, procurando uma "moça jovem para entreter as tropas", "talento", no jargão empresarial de Trout. O objetivo é usá-la como atração em um evento para arrecadação de fundos de campanha. Brincando de parecer o que não é, Martha sai do banheiro usando uma peruca diferente daquela com que entrara e não é reconhecida por Bud, o namorado da vez. O simulacro da personagem que, não custa lembrar, trocara de nome na sua volta à cidade, é associado pela narração a outros dois: um "truque de magia" barato, feito pelo prestidigitador misterioso, atrai a atenção de Martha, junto com a nossa, mas, no extracampo, é no ilusionismo contido na fala de Trout que o espectador alerta deverá concentrar-se.

Trout: Sueleen, estou tão orgulhoso de você, neném. (Mentindo descaradamente) Quero dizer, você arrasou com eles. Estava todo mundo enlouquecido com você, querida. Oh, como foi bonito! Docinho, é preciso atitude para ser uma estrela. O que é que eu posso te dizer, Sueleen?

Sueleen: Então o emprego é meu?

Trout: Docinho, eu te consegui um emprego enquanto você cantava. (Sueleen exulta). Um amigo meu, gente muito importante, acabou de ligar. Tem uma festa segunda-feira à noite. Agora, o pagamento não é muita coisa, porque é negócio de baixo orçamento. Dez dólares!

Sueleen: Eu não ligo pra dinheiro.

A montagem paralela sugere que as duas sequências sejam analisadas em conjunto, como exposições parciais de um mesmo problema, mas também separadamente, na medida em que algumas questões tratadas em uma não são espelhadas diretamente na outra. Um traço em comum é a divisão da cena em dois movimentos: no Old Time Picking Parlor, a apresentação de uma música "de raiz" pela banda semiprofissional (folclórica) é seguida de uma confusão envolvendo um tema racial; no Deemen's Den, a apresentação de uma música "de raiz" pela dupla amadora é seguida pela 
contratação de Sueleen para um evento político (a festa de arrecadação de fundos de campanha).

Se o quadro temático não apresenta uma chave para uma interpretação incontestável, ele fornece, na figura da música "de raiz", uma mediação para que tentemos ao menos afrouxar o nó ideológico criado pela montagem paralela. Gênero de música caipira, cujo "código genético" negro e branco trazia uma promessa de democracia racial para a cultura sulista, o bluegrass foi uma das formas "destronadas" pelo desenvolvimento do country na direção de um ritmo pop, o Nashville Sound. Tal processo de diluição das marcas raciais na música caipira e sua substituição por um som "pasteurizado" teve início nos anos 1950, quando a geração de Elvis Presley e Jerry Lee Lewis apresentou um tipo de música caipira (hillbilly) com forte influência do rhythmand-blues. Era o nascimento do rockabilly, uma "encarnação" ancestral do rockand-roll. O novo ritmo popular "retirava muito de seu conteúdo e estilo de fontes negras", mas era "executado por gente branca para públicos brancos" ${ }^{\text {"155. }}$ Encorajada pelo sucesso dos "rockabillies", a indústria passou a promover músicos com um estilo mais pop, desbastando as antigas influências da classe trabalhadora, branca e negra, na música country, e aproximando-a de sua forma mais difundida até hoje.

Esse apagamento da linhagem racial da música country trouxe uma "conveniente" imagem de "neutralidade política" para a indústria durante os anos 1960 e 1970, uma época apreendida no verso da dupla principiante no Deemen's Den como "tempos atribulados". De fato, com a consolidação do Nashville Sound, o sentido contestatório de um cantor negro como Tommy Brown em meio à oficialidade country é invertido; ele não é mais um indício da origem radical (no sentido de suas raízes) dessa música, mas a imagem que sobra de um processo de apagamento. Como lembra Diane Pecknold,

${ }^{155}$ MALONE, Bill C. Country Music, U.S.A. p. 247. 
"em parte a despeito de e em parte por conta da presença de artistas negros tais como Charley Pride, Linda Martell e O. B. McClinton, a música country era, no início dos anos 1970, indubitavelmente branca sem ser, no entanto, expressamente antinegra; de fato, foi precisamente por isso que os teóricos da Nova Maioria reconheceram sua utilidade. Nenhuma outra forma cultural permitia a um só tempo abraçar de maneira tão clara as tradições e valores do Sul e expressar uma posição moderada no que tange aos direitos civis."156

Naquele momento em que a situação política exigia a tomada de posições, os olhos da nação se voltavam para o Sul: os "gerentes" da campanha de Nixon viam na região o "fiel da balança" que traria a presidência de volta para o Partido Republicano; na "onda" do folk revival, a esquerda, instalada nos cursos universitários de estudos de folclore, ressuscitava 0 interesse na música bluegrass; mais reveladora, entretanto, foi a chegada de investimentos aos diversos setores industriais da estrutura produtiva sulista, atraídos pelas possibilidades abertas pela reestruturação da economia norteamericana, naqueles estados historicamente refratários ao sindicalismo.

Michael Denning lembra que, a partir dos anos 1930, a migração Sul-Norte desorganizara o movimento social da Frente Popular, pois, enquanto a classe trabalhadora do Norte "tinha raízes profundas nos radicalismos europeus - [...] - os migrantes sulistas chegavam com pouca história de radicalismo de esquerda"157. Agora, com o processo de "desindustrialização" nos estados sindicalizados do Norte, o desmanche do sonho de uma cultura da classe trabalhadora superando diferenças raciais e regionais se confirmava no movimento inverso, numa volta ao Sul.

"Outrora o lugar preferido para investimentos dos ramos mobiliário e têxtil, o Sul se tornou, a partir dos anos 1970 e 1980, o local de instalação de indústrias variadas, especialmente dos setores automobilístico, elétrico e, recentemente, de tecnologias da computação. A explicação para essa mudança de posição do Sul está na reestruturação da economia norte-americana. $O$ Sul se mostra hospitaleiro em relação às estratégias corporativas de diminuição de gastos com trabalho por meio do estabelecimento de ambientes industriais sem sindicatos [...]. Igualmente importante é o fato de o Sul atrair muitos

${ }^{156}$ PECKNOLD, Diane. The Selling Sound. p. 226. 
trabalhadores das dizimadas regiões industriais do Norte e do Meio-Oeste, temerosos de perder seus empregos caso se sindicalizem." ${ }^{158}$

A questão, portanto, é muito complexa e a acusação de Wade ("Tommy Brown é o preto mais branco da cidade") desafia a análise, mostrando-se como uma "rocha sedimentar" formada pelo acúmulo de significados históricos. O ataque físico de Wade a Kenny, identificado pelo comentário de Mary como um redneck ("Ele se parece com Howdy Doody"159), pode ser encarado como uma expressão de pessimismo do ponto de vista narrativo quanto à possibilidade de alianças de classe transraciais dentro do universo de relações produtivas que se vai desenhando. Ao mesmo tempo, dada a importância de Kenny para a conclusão do filme (é ele o autor de um assassinato político), o fato de que o encontro dos dois personagens desvalidos resulta em choque, em vez de aliança de interesses, pode ser visto como a alegoria de um impasse político, de cuja resolução depende a criação de uma frente eleitoral de esquerda nos EUA.

$\mathrm{Na}$ "outra face" da montagem paralela, no Deemen's Den, a dupla que precede Sueleen também a ataca, não física, mas verbalmente, por meio de um comentário sobre sua performance ("Que horrível!"), marcando, nos versos de sua canção, a preferência por alianças espirituais: "O Senhor é o melhor amigo que tenho." Em face da competição acirrada por um lugar nos negócios country, é compreensível que as Smokey Mountain Laurels não vislumbrem a possibilidade de uma relação de camaradagem com Sueleen e que os Misty Mountain Boys também cantem a sua solidão: "Me sinto tão solitário rolando rio abaixo". O mesmo vale para Wade e Kenny, assim como os demais músicos principiantes ou subempregados nos dois espaços cênicos: Albuquerque fugindo às garras do marido para gravar um

\footnotetext{
${ }^{157}$ DENNING, Michael. The Cultural Front. p. 36.

${ }^{158}$ ARONOWITZ, Stanley. From the Ashes of the Old. p. 101.

159 "Redneck" é um dos termos pejorativos usados para designar a classe trabalhadora branca sulista. "Howdy Doody" é uma marionete usada em um programa infantil. Com figurino de cowboy e a cara sardenta, o personagem ridiculariza o redneck.
} 
"disco demo"; Frog, o pianista demitido, aceitando o trabalho de violonista no bar de calouros.

Ao anunciar Tommy Brown como um star, Lady Pearl faz um elogio indireto à indústria cultural que o acolheu, a mesma que exclui e colocou os amadores em rota de colisão. Em nível simbólico, esse elogio sugere que a "via sulista" para a integração dos negros à sociedade é preferível àquela defendida pelos movimentos de direitos civis dos anos 1960 e 1970, cujos resultados seriam apenas violência gratuita, como aquela causada por Wade. Não por acaso, Haven Hamilton trata de distanciar o clube de Pearl e a cultura country de qualquer associação com ativismo: "Esse tipo de coisa não é comum no bar de Lady Pearl. Não é comum em Nashville." O desdobramento lógico do elogio implícito é a conclusão de que a extensão da cidadania aos negros, que as políticas "excessivamente permissivas" de governos democratas não foram capazes de fazer, a indústria fonográfica realiza cotidianamente, sem alarde e sem violência.

Mais uma vez, Wade, que no aeroporto já havia desmascarado a venalidade dos artistas country ao falar de Barbara Jean ("Essa daí só canta por dinheiro"), torna-se um veículo para a expressão de um ponto de vista sobre as relações de produção nesse ramo da indústria cultural: se o preço cobrado a Tommy Brown para aceder ao trabalho na música foi o seu "embranquecimento", entendido aqui como a ruptura de seus alinhamentos de classe e a negação de seus valores culturais, então a sua absorção não pode ser tratada como um processo de integração, e sim como um desmanche predatório da cultura branca sobre sua ancestralidade negra. O ponto de vista narrativo já havia antecipado essa questão na sequência dos estúdios, ao mostrar a cantora branca desafinada como lead singer de um coral gospel negro; se, na relação cotidiana das classes dentro do aparato country, o cantor negro se torna "o preto mais branco da cidade", Linnea, por sua vez, não sofrera um processo análogo de "enegrecimento". 
A montagem paralela das cenas sugere que 0 espectador carregue o desmascaramento ideológico de uma para a outra, não se deixando enganar por truques tais como aquele efetuado pelo prestidigitador e pela troca de perucas de Martha. Ao mentir descaradamente para Sueleen, dizendo que seu show foi digno de uma star, Trout dá uma forma mais grosseira à sutil ilusão contida no elogio de Pearl. Quer seja oferecendo Tommy Brown à plateia, quer seja oferecendo Sueleen como "talento para entreter as tropas", os dois empresários do ramo musical não deixam dúvidas de que é como "banco de talentos" que a indústria encara trabalhadores em disputa fratricida para entrar e manter-se nos seus quadros. Com isso, a narração começa a tocar em um dos "segredos" do sucesso empresarial do country: auxiliada por um ambiente propício à saúde dos negócios, leia-se, por uma estrutura produtiva com baixíssimos níveis de sindicalização, essa indústria construiu em Nashville um "exército de reserva" apaziguado e disposto a trabalhar, contra seus pares, em troca de pagamento mínimo. O cachê das Smokey Mountain Laurels é uma cerveja e quando Trout avisa a Sueleen que ela receberá apenas dez dólares por sua performance, ela responde, resignadamente: "Eu não ligo pra dinheiro".

Essa disponibilidade dos principiantes de Nashville para trabalhar quase de graça é explorada no próximo quadro temático, formado pela justaposição de várias cenas curtas, retratando o cotidiano matutino da cidade. Dentro de um carro destrancado, Albuquerque, a própria imagem do desvalimento (sem casa, sem emprego, com pouca roupa), acorda e vasculha a bolsa antes de se lançar ao trabalho em que se tornou especialista: a busca por um emprego. No fundo do enquadramento que nos apresenta a personagem, uma briga de trânsito revela o espaço concorrencial onde se dá a sua busca. $\mathrm{Na}$ trilha sonora, Walker discursa sobre problemas "que o dinheiro sozinho não consegue resolver". Em uma rua residencial e aparentemente periférica, a leitura das notícias matutinas por Mr. Green é interrompida pela chegada de Kenny, músico desempregado, em busca de um quarto para alugar. Se o velho Mr. Green já não pode sonhar com um posto de trabalho na indústria da música, a sua casa pode servir de opção barata para a acomodação de principiantes. No 
hospital, Barbara Jean acorda, surpreendendo Kelly, seu "stalker", que a "velara" durante a noite. Na elegante casa dos Reese, Linnea dá aula de "música gestual" a seus dois filhos surdos. Em um quarto de hotel, Tom, o astro do rock, desperta Opal, a jornalista com quem passara a noite e a quem dera uma entrevista na véspera. Assim como Albuquerque, Tom, cuja principal atividade é a sedução, começa a "trabalhar". Telefona aos Reese na tentativa de atrair Linnea para um encontro, mas a conversa é ouvida por Del, o marido. Conforme Del repõe o telefone no gancho, uma espécie de "rima gestual" liga a sequência a outro espaço, o hospital, onde uma mulher retira o telefone do gancho para fazer uma chamada. Com a imagem do vaivém na recepção do hospital, o grupo temático se encerra, deixando uma avaliação sobre a passagem do tempo em Nashville: ainda que se trate de uma cidade de serviços, em que os horários de trabalho são, supostamente, mais flexíveis, o despertar coletivo, seguido por agitações cujo elemento em comum é a relação com a música, sugere um ritmo industrial, em que os ciclos de produção e descanso coincidem em todo o espectro social.

O quadro temático seguinte é formado por três longas sequências, e duas cenas mais breves, organizadas ao redor de uma apresentação do Grand Ole Opry, um programa de rádio ao vivo diretamente relacionado à história da cultura country e do Nashville Sound. Embora o filme já tivesse tocado, indiretamente, nas relações da country music com outras indústrias culturais, esse é o primeiro quadro temático em que o universo do rádio e o culto das celebridades cinematográficas se torna, efetivamente, um assunto central. Também é a primeira vez em que três sequências consecutivas se ligam por continuidade narrativa: numa festa em sua casa de campo, Haven anuncia que se apresentará, mais tarde, no Grand Ole Opry; a próxima sequência é justamente a edição daquela tarde; a última sequência é uma espécie de happy hour dos convidados do programa em um bar de música ao vivo: o King of the Road. Entrementes, uma cena no quarto de Barbara Jean no hospital e outra no quarto de vestir de Sueleen retratam as ouvintes do 
programa, sugerindo que o Grand Ole Opry cumpre uma função de coesão cultural na cidade.

A primeira tomada do quadro é um plano médio do misterioso prestidigitador montado em seu triciclo, trazendo Opal e Albuquerque à casa de campo de Haven. A apresentação ocorre in media res, deixando escapar, nas últimas palavras de um diálogo interrompido, o nome de um filme, Little Women (George Cukor, 1933, ou Mervin Leroy, 1949). O veículo incomum suscita um comentário de Linnea, conversando com uma senhora de meia idade: "Desde aquele filme, Easy Rider, é esse o tipo de moto que todo mundo está pilotando". Ao comentário, Linnea ainda adiciona uma história de jovens que ficaram paralisados da cintura para baixo por guiar tais motocicletas. No canto reservado aos "rega-bofes", Wade trabalha como garçom e Albuquerque se serve, no que parece ser sua primeira refeição do dia. A esta imagem, a narração sobrepõe um comentário de Opal ("Isso tudo é muito Bergman. Bergman puro, inadulterado"), seguido de uma ressalva: "É claro que essas pessoas todas não têm nada a ver com Bergman, não é mesmo?"

"O persistente sistema de classes sulista em Nashville, tal como representado por Haven Hamilton, é duplamente reforçado pelo papel servil do negro na festa" ${ }^{160}$ e pela imagem da cantora principiante tentando conseguir comida de graça; as especificidades desse sistema são enfatizadas pela narração ao criar uma sincronia entre o comentário de Opal sobre a aparência da casa de campo e a imagem dos dois excluídos dos festejos, sugerindo que os modelos estrangeiros (Bergman) não servem para a leitura deste sistema de classes. Em outro canto da propriedade, Lady Pearl, Haven e Triplette discutem política:

Pearl: Sr. Triplette, eu sinto muito se Delbert falou que Haven apareceria em um comício. Ele já deveria saber que nós nunca deixamos Haven Hamilton comprometer-se politicamente.

${ }^{160}$ STUART, Jan. The Nashville Chronicles. p. 176. 
Haven: O senhor entende; nós fazemos contribuições a todo mundo. E não são contribuições pequenas.

Pearl: (Emocionada) A única vez que eu fugi à regra e me deixei levar foi pelos Kennedy, mas eles eram diferentes.

Neste ponto, já começa a ficar claro que a técnica de composição da cena é a mesma usada na sequência do engarrafamento: um grande conjunto, em forma de mosaico, dividido em pequenos núcleos, a maioria resultante de improvisações. Na limusine dirigida por Norman, chega Elliot Gould, um astro de cinema em ascensão nos anos 1970, interpretando a si mesmo. Na saída do carro, um rápido diálogo com o motorista:

Norman: Eu só queria saber o que o senhor está fazendo em Nashville.

Gould: Eu vim para uma festa. E você? O que está fazendo em Nashville?

Norman: Eu estou emperrado aqui.

O diálogo traz à tona a dialética entre essência e aparência que orienta a composição da cena. A festa em que todos trabalham e confraternizam sugere que a "Music City" é um lugar onde a diversão não para. Não obstante, essa imagem é invertida antes de fixar-se, na medida em que o "olhar da câmera" vai buscar também o seu avesso na jornada estendida de uma classe de "serviçais", para quem o trabalho sem regras não é vivido como uma experiência prazerosa ("Eu estou emperrado aqui”).

No canto de Haven, Lady Pearl se retirou, mas a conversa sobre política continua. Por meio da disposição dos atores no enquadramento, o foco narrativo estabelece uma comparação entre seus personagens: Haven, o astro da música, bebe seu copo de leite de pé, de modo que sua estatura é igualada à de Triplette, sentado sobre uma mesa. 
Triplette: Haven, escuta, eu seria a última pessoa do mundo a tentar te convencer a fazer uma coisa que você não quer, mas eu gostaria de te explicar o que nós pretendemos nesta campanha antes de você descartar completamente esta possibilidade. Eu não sei como você vai se sentir sobre o que eu tenho pra te dizer, mas Walker acha que você daria um ótimo governador para o estado do Tennessee. Ele também acha que o momento é propício. Ele acha que o povo do Tennessee te adora. Ele está certo disso. E ele quer que você saiba que, no momento certo, se você quiser concorrer, a organização dele está disposta a te apoiar durante todo o processo.

Haven: Você estará no Opryland hoje à noite? Pois bem, eu estarei no Opryland hoje à noite e é lá que eu vou te dar uma resposta.

Agradecendo em tom servil, Triplette se levanta, ressaltando a diferença de estatura entre ele e Haven. Novamente, surge aqui uma armação dialética entre aparência e essência. Distribuindo ordens e "posando" de "estrela caprichosa", que adia a resposta óbvia para fingir controle sobre suas escolhas, Haven traduz seus delírios de poder em seus gestos e na sua fala. Do lado de Triplette, a estratégia é mais cuidadosa e a servilidade dá o tom da atuação.

Em um conhecido ensaio sobre a relação das artes cênicas com tendências políticas autoritárias, o dramaturgo Arthur Miller afirma que

"como regra geral, talvez até como um axioma, quanto mais perto se chega de qualquer tipo de poder, maior é a quantidade de atuação que se é obrigado a usar. A questão é exatamente saber quanto. Máscaras e maquiagem datam de tempos primitivos, é claro. [...]. Mas estamos tão acostumados com sinais de poder que raramente os notamos, de modo que eles se tornam difíceis de rastrear em nossas consciências. Ainda assim, 
o futuro da democracia depende, é desnecessário dizer, da nossa capacidade de reconhecer e controlar estes sinais." ${ }^{161}$

Transformando o diálogo entre Haven e Triplette em uma disputa velada de simulações, a narração ressalta os "sinais de poder" naturalizados por uma vida cotidiana tomada pelo espetáculo, dando assim o primeiro passo (o seguinte cabe ao espectador) para o "reconhecimento" e o "controle" intelectual de formas de autoritarismo no plano da imagem. A antiga autoridade patriarcal, que Haven quer atualizar em seu comportamento e em seu figurino de cowboy, é desautorizada pelo gesto de beber leite; do lado de Triplette, as aparentes reverências ao poder constituído, cifradas no tom servil e paciente, são desmascaradas pelo enquadramento que revela a diferença de estatura entre os dois atores, sublinhando a profunda assimetria de suas posições: só Triplette pode prometer "falsos brilhantes"; a espera paciente é, neste caso, uma prerrogativa de quem detém o poder de fato.

Vindo para perto de Haven, na intenção de apresentálo a Elliot Gould, Del se desculpa por não ter reconhecido o famoso astro de cinema: "Eu apertei a mão do cara achando que ele era apenas uma pessoa comum". Ao lado de uma cisterna, Opal convence Bud, o tímido filho de Haven, a Ihe mostrar a única canção que compôs. No meio do verso que diz "porque vem do coração de uma mulher gentip" ${ }^{162}$, o olhar em off da jornalista capta a presença de Elliot Gould e seu rosto entorpecido "se acende" repentinamente. De modo grosseiro, essa "mulher gentil" abandona Bud e corre atrás de um furo de reportagem, microfone à mão, tentando arrancar uma entrevista exclusiva: "Você se lembra de mim? Opal, da BBC! No Festival de Cannes!" Mais uma vez, Haven toma para si a responsabilidade de expulsar a inoportuna intrusa: "Eu não sei quem é você ou que está fazendo aqui, mas eu não vou tolerar falta de educação na presença de um star, quero dizer, dois stars", diz, sem deixar claro se o segundo astro é ele mesmo ou se é Gould.

${ }_{161}$ MILLER, Arthur. On Politics and the Art of Acting. p. $26-27$.
162 "Because it comes from the heart of a gentle woman." 
A cena adiciona camadas de sentido ao delineamento da situação material de Opal e do trabalho artístico e intelectual que ela representa. Produzindo um documentário sobre Nashville, uma cidade carregada de espetáculos, ou seja, de simulações, ela busca um toque de humanidade na canção de Bud, a única que ele compôs e que não tem coragem de mostrar a ninguém. Porém, o "instinto" de repórter de celebridades, "farejando" pequenas oportunidades de ganhar algum dinheiro, dispara em Opal uma reação automática que Ihe faz abandonar a conversa com Bud para tratar de futilidades com Elliot Gould. Na transição para a "tietagem" de Elliot Gould e desta para a expulsão humilhante da festa de Haven, Opal retrata a insegurança material do intelectual moderno, tentando equilibrar o desejo de estabelecer uma comunicação genuína com seus pares e os ditames comerciais de um mercado de celebridades do qual ela depende para sobreviver, mas que não cessa de pisoteá-la ${ }^{163}$.

Do comentário feito por Haven após expulsar Opal de sua festa ("Fazer o quê? É o preço do sucesso"), a montagem corta diretamente para uma tomada do prestidigitador guiando seu triciclo sobre uma autoestrada, transformando o personagem, mais uma vez, em um recurso de coesão no plano da imagem. A estrada vai dar numa espécie de parque temático, identificado por uma enorme placa colorida: "Opryland USA", "Home of American Music". Mais abaixo, em letras menores, são anunciadas as atrações do dia, em ordem de importância: "Connie White, Haven Hamilton, Tommy Brown". Na trilha sonora, um locutor introduz a vinheta de abertura de um programa de rádio:

"Peguem um GooGoo, meus amigos, e se sentem para ouvir trinta minutos do melhor programa de rádio, o Grand Ole Opry! (Corte para a imagem de um auditório, em cujo palco se desvela um cenário country: acima, um anúncio do patrocinador; abaixo, o nome da estação, WSM, do programa e de suas coordenadas no "dial'). Ele chega a

163 "Os intelectuais, [...], são completamente dependentes do aparato, tanto social quanto economicamente; o aparato é o único canal para a realização de seu trabalho. A produção de escritores, compositores e críticos cada vez mais ganha a feição de matéria prima. A obra acabada é produzida pelo aparato". BRECHT, Bertolt. The Modern Theatre is the Epic Theatre 
você como um oferecimento dos fabricantes de GooGoo, o melhor doce do mundo, e do torrone King Leo (Rei Leão), o doce que ruge de sabor. Agora, por favor, uma salva de palmas para o 'GooGoo Man' do momento: Tommy Brown.”

Um filme que mapeia a cultura norte-americana a partir da country music não poderia deixar de dedicar uma sequência inteira a um programa de rádio ao vivo, pois

"A música caipira foi, acima de tudo, uma criação do rádio. [...]. De meados dos anos 1920 até o fim da Grande Depressão, o rádio foi a pedra de toque da economia caipira. Poucos artistas sobreviviam com os cachês pagos pelas estações e menos ainda com os direitos autorais gerados com a publicação e a gravação de discos, mas o programa de rádio servia como meio de publicidade dos produtos que efetivamente sustentavam os músicos: os shows ao vivo que compunham a parte central da sobrevivência de qualquer músico caipira, as fotografias e canções autopublicadas e vendidas diretamente pelos músicos e, de menor importância, as gravações comercializadas pela indústria da música."164

Dois programas semanais se destacam na história da música country. Transmitido desde Chicago pela rádio WLS, o National Barn Dance popularizou o formato de shows musicais ao vivo, intercalados por comerciais, em transmissões que duraram de 1924 a 1968, inspirando o seu principal concorrente, o Grand Ole Opry, transmitido desde Nashville pela rádio WSM, de 1925 até hoje. Durante esses quase noventa anos, o Opry passou por várias modificações, incluindo uma versão para TV a cabo em 1985 e transmissões pela Internet a partir de $2000^{165}$; porém, de todas as mudanças experimentadas pelo programa, a mais importante foi aquela de que ele é também uma das causas: a popularização da música country a partir de um "produto" mais homogeneizado.

"A emergência do country pop é concomitante ao desenvolvimento de Nashville como um centro de produção musical. Estes dois fatores

(Notes to the opera Aufstieg und Fall der Stadt Mahagonny) in: WILLETT, John (ed.). Brecht on Theatre. p. 35, nota de rodapé.

${ }^{164}$ PECKNOLD, Diane. The Selling Sound. p. 15.

165 OERMANN, Robert K. Grand Ole Opry: the show that made country music famous. Disponível em http://www.opry.com/about/WhatlsTheOpry.html (consultado em 02/04/2012) 
convergiram para impulsionar o surgimento daquilo que logo seria conhecido como Nashville Sound. [...] o Grand Ole Opry foi um catalisador para o encontro de talentos variados, com sua rede de promotores, agentes e editores, na Nashville do pós-guerra. A proliferação de estúdios e editoras de música, que se alimentavam mutuamente, encorajou músicos e compositores a se basearem permanentemente na cidade. 'Sessions musicians', como eram chamados, eles raramente faziam turnês ou se tornavam membros de bandas profissionais; em vez disso, ficavam de plantão para o caso de algum cantor necessitar de seus serviços em trabalhos de gravação. Com isso, eles se familiarizaram com vários estilos diferentes e desenvolveram um sistema numérico que lhes permitia adaptar e transpor partituras facilmente, enquanto aprendiam novas canções. Os músicos de Nashville tornaram-se famosos por sua versatilidade e habilidades de improvisação, contribuindo para a reputação de Nashville como 'Music City, USA' e para o apelo mercadológico mundial do produto musical que emergia na cidade. Infelizmente, a sua presença, disco após disco, inspirou uma mesmice sonora que inibiu a criatividade dentro do campo da música country."166

\section{O momento em que a narração volta seus olhos sobre}

- Grand Ole Opry é de consolidação dessa "mesmice", entendida como um processo de transformação da música caipira em uma mercadoria produzida em condições industriais para ser distribuída nacional e internacionalmente, o que talvez explique a ênfase colocada sobre os anúncios de doces e do próprio cantor como o "GooGoo Man do momento". A novidade não é o anúncio em si; muito pelo contrário, pois a música caipira, desde seus primórdios,

"não apenas forjou uma relação mais próxima com a publicidade do que tinham outros gêneros, mas também se associou àqueles anunciantes considerados mais baratos [...] tais como produtores de alimentos básicos e remédios." ${ }^{167}$

\footnotetext{
${ }^{166}$ MALONE, Bill C. Country Music U.S.A. p. $256-257$.

167 PECKNOLD, Diane. The Selling Sound. p. 18 - 19. De fato, tanto King Leo quanto GooGoo, os dois fabricantes de alimentícios anunciados na sequência, são marcas comerciais verdadeiras e patrocinadores de longa data do Grand Ole Opry. Esta última, cujo nome onomatopéico sugere o som feito por bebês, traz as iniciais do programa de rádio, mas sua existência o precede em treze anos. Vendido em Nashville a partir de 1912, o "GooGoo Cluster" é uma espécie de torrone feito com marshmellow, amendoins torrados e caramelo, cobertos por chocolate ao leite. Durante a Grande Depressão, foi criado um sugestivo slogan para o GooGoo Cluster, cujo uso se extenderia até os anos 1950: "a nourishing lunch for a nickel" ("um alimento nutritivo por cinco centavos").
} 
O que particulariza o Grand Ole Opry em 1974, ano em que serviu de cenário para Nashville, é a adequação do antigo programa de rádio à onda de modernização capitalista na cidade, mudando-se

"de uma vizinhança decadente na região central de Nashville para um espaçoso parque no subúrbio: 'Opryland U.S.A'. O parque era uma atração de $3290 \mathrm{~m}^{2}$ 'projetado para ser a casa da música norte-americana' e abrigo do edifício do Grand Ole Opry, que um repórter acidamente descreveu como 'uma prova de 15 milhões de dólares, em tijolinho à vista, de que a música country é tanto um hábito nacional quanto uma indústria em franca expansão'. O Opryland combinava atrações envolvendo animais, concessões privadas, lojinhas de presentes e áreas de alimentação, em um parque de diversões country para a família e para o turista e, à época da inauguração do novo auditório, já recebia dois milhões de visitantes ao ano. [...]. Assim como o Hall da Fama da Música Country, [o novo endereço do Grand Ole Opry] foi recebido como um atestado da respeitabilidade e do poderio comercial do country, para o bem e para o mal. Enquanto a revista U.S. News \& World Report atribuía ao parque o incremento no turismo e uma bolha no setor de construção, alguns fãs advertiam que 'é natural que as pessoas fiquem descontentes com o sucesso comercial' e que o Opryland poderia ser prejudicado por sua associação com o comercialismo do Nashville Sound."168

Identificada na fala de Albuquerque ao chegar à entrada do auditório ("É o novo [endereço]; sim, é novo mesmo"), a mudança do Grand Ole Opry para o Opryland foi mais uma das ações empresariais que "empacotaram" a música caipira tradicional numa "embalagem" mais adequada ao competitivo mercado do entretenimento, gerando reações que misturavam entusiasmo e ceticismo ${ }^{169}$. De certa forma, é possível dizer que estas duas

\footnotetext{
${ }^{168}$ PECKNOLD, Diane. The Selling Sound. p. 226.

${ }^{169}$ Uma das reações mais sentidas à mudança de endereço do Grand Ole Opry veio de Garrison Keillor em um artigo publicado na revista New Yorker em maio de 1974 ("Onward and Upward with the Arts at the Opry") "A viagem a Nashville que inspirou o artigo de Keillor teve consequências positivas. No mês seguinte, ele voltou para casa, em St. Paul, Minnesota, e fundou um maravilhoso programa de rádio, A Prairie Home Companion, idealizado para restaurar o sabor e a ambientação dos antigos programas ao vivo." MALONE, Bill C. Country Music U.S.A. p. 370, nota de rodapé. Em 2006, o término ficcional das transmissões de A Prairie Home Companion, causado justamente pela compra do teatro onde ocorrem as gravações por um grande empresário que o quer transformar em estacionamento, viria a ser o argumento do último filme de Altman - A Última Noite (A Prairie Home Companion) - contando com o próprio Keillor, interpretando a si mesmo. As comparações com Nashville foram inevitáveis: em um especial da revista Positif, Eithne O'Neill entendeu que o filme "pertence a uma era pós-moderna na qual não se podem recuperar as canções de um retorno impossível" (The Last Show: Asphodèle ou la nostalgie post-moderne. p. 16); em uma entrevista publicada no mesmo número, Altman admitiu
} 
atitudes se reproduzem na sequência do filme dedicada à representação do Grand Ole Opry; conforme a narração transita das apresentações impecáveis de Karen Black (Connie White) e Timothy Brown (Tommy Brown) no palco para humilhação de principiantes nos bastidores, as reações contraditórias às mudanças que ocorriam na cidade vêm à tona como o direito e o avesso de um processo de modernização avassaladora.

\section{O primeiro cantor a se apresentar no palco do} programa é Tommy Brown; a canção apresentada é "Bluebird", uma composição de Ronee Blakley, a atriz que interpreta Barbara Jean:

"Tenho andado por esta estrada longa e solitária, baby, tenho andado há um bom tempo.

Tenho andado por esta estrada longa e solitária, baby, atrás de um sorriso especial.

Trabalhei em bares, de Nova lorque a San Francisco, mas o dinheiro nunca dava.

Sabe como é, o dinheiro vai embora, escorregando pelos dedos; um dólar a mais, um dia a mais.

Mas o pássaro azul não tem dinheiro, o pássaro azul não tem família.

O pássaro azul não usa relógio de ponto; é só ao vento que ele responde."170

que os dois filmes estão relacionados: "eu não vejo meus filmes como entidades distintas. Para mim, são capítulos de um mesmo livro ou os fios de uma mesma tapeçaria. Portanto, certamente há vários tipos de relação entre Nashville e A Última Noite". HENRY, Michael. Entretien avec Robert Altman: Tout est spectacle. p. 21. Em um artigo publicado na revista NAU, Marcos Soares reconhece as citações não apenas a Nashville, mas também a vários outros filmes de Altman, rejeitando, contudo sua leitura em chave nostálgica. SOARES, Marcos. Estética e Política em Robert Altman. Revista Nau, São Paulo, v. 1, n. 1, jan./jun. 2008, p. 95 - 105.

170 "I've been going down that long lonesome road, babe, l've been doing it for a while./ And l've been going down that long lonesome road, babe, looking for a special smile./ Now, l've worked the bars, New York to Frisco, but I could never make it pay./ You know how money goes, it slips right through your fingers; one more dollar, one more day./ The bluebird, he has no money, the bluebird, he has no kin./ The bluebird, he wears no time-clock, he answers to the wind." 
O palco está tomado por toda sorte de funcionários técnicos da rádio e pelos séquitos de cada cantor; a narração os apresenta em planos "claustrofóbicos", cujas molduras são ocupadas por fragmentos dos assuntos excluídos da centralidade do enquadramento. O espaço, portanto, é sufocante e restringe os movimentos do corpo atlético de Tommy Brown que, levemente curvado sobre o microfone fixo a um pedestal, apenas agita os braços, acompanhando sua performance vocal tecnicamente perfeita. Posteriormente, ele retira o microfone do pedestal, mas seu percurso no palco não vai muito além daquele ponto de onde partira.

O primeiro número musical do Grand Ole Opry dialoga com o quadro temático formado pelas apresentações de amadores no "Old Time Picking Parlor" e no "Deemen's Den"; o elogio de Pearl ("Temos um star presente nesta noite"), a precariedade do trabalho amador, o desmanche de estruturas de solidariedade racial e de classe e a acusação de Wade ("Tommy Brown é o preto mais branco da cidade") são alguns dos temas referidos ou respondidos na letra da canção e na performance do cantor. $O$ anúncio de Brown em meio ao slogan do fabricante de doces ("o GooGoo Man do momento: Tommy Brown") espelha negativamente o elogio de Pearl, dando uma conotação comercial à palavra "star". O estilo Nashville Sound da canção, que não permite "voos mais altos à sua performance", reproduz, na forma musical, as limitações que o espaço cênico restrito traz à sua expressão corporal. A rotina aborrecida do cantor empregado pela indústria fonográfica é retratada, em negativo, como o reverso do sonho de liberdade cantado no estribilho: "O pássaro azul não tem dinheiro", mas Tommy Brown é obrigado a vender os torrones GooGoo para tornar-se viável como cantor; "O pássaro azul não usa relógio de ponto”, mas o cantor recebe por hora e adéqua seu tempo à sequência de programação e comerciais do rádio. Nas contradições entre a canção e a situação do cantor, revela-se o sentido do "embranquecimento" a que Wade se referira: tornar-se o "preto mais branco da cidade" significou a venda dos sonhos de Tommy Brown em troca de um trabalho insatisfatório. 
O "eu-lírico" da canção reconhece o preço pago, rejeitando, todavia, a alternativa de seguir como amador, que ele avalia como financeiramente insuficiente: "Trabalhei em bares, de Nova lorque a San Francisco, mas o dinheiro nunca dava./ Sabe como é, o dinheiro vai embora, escorregando pelos dedos; um dólar a mais, um dia a mais". Em que pese certo cinismo no reconhecimento, as "escolhas" sugeridas na letra foram mais do que acertadas; de fato, entre vender-se no varejo, ganhando a sobrevivência diária, cachê por cachê, e vender-se no atacado, tornando-se uma atração fixa no horário patrocinado pelo fabricante de doces, a lógica da sobrevivência, inclusive artística, não deixa dúvidas sobre qual caminho seguir.

Entretanto, o interesse crítico da canção não se situa naquilo que o "eu-lírico" abandonou para enquadrar-se, mas sim no que ele visualiza como um ideal ainda não atingido: a liberdade do voo solitário do pássaro azul ("O pássaro azul não tem família"), movido pelo tempo subjetivo, em vez do relógio de ponto; sem compromisso com ninguém além de si mesmo, "é só ao vento que ele responde." $\mathrm{Na}$ imagem singela, revela-se que o engessamento mais profundo trazido pelo country e pelo Nashville Sound ao cantor foi a atrofia de sua imaginação utópica; o sonho de liberdade que ele canta é uma miragem de retrovisor. Na figura do "pássaro azul", a rebeldia contra as novidades da produção industrial e do Nashville Sound é apaziguada em um lamento nostálgico pelo fim da era "pré-moderna" da música caipira; ao mesmo tempo, a solidão experimentada pelo artista em concorrência feroz com seus companheiros no ambiente profissional ("Tenho andado por esta estrada longa e solitária”), um estrago causado pela modernização, é esvaziada de seu conteúdo negativo e lançada como ideal na figura do pássaro que voa sozinho.

$\mathrm{Na}$ representação deste primeiro número musical, já fica evidente que o estilo de composição da cena é fundado sobre o princípio da contradição. Recortando uma canção viabilizada pelo trabalho coletivo no set (composta por uma das atrizes no elenco), a narração constrói um pequeno comentário sobre as forças históricas que atuam para dissolver a capacidade de 
imaginar soluções coletivas. Aproximados pela origem de classe e pela bagagem cultural em comum, Wade e Tommy Brown figuram duas reações opostas e igualmente fracassadas ao processo de modernização capitalista em Nashville. No primeiro, o fracasso tem a forma patente da miséria material, com o subemprego, o alcoolismo, etc.; no segundo, a miséria é existencial e, apesar de seu recalcamento na alegria aparente da canção e no corpo atlético de Timothy Brown, ela fica registrada nas imagens negativas do pássaro azul e na contenção dos movimentos corporais do ator pelas estruturas físicas do programa de rádio ${ }^{171}$.

O intervalo entre uma apresentação e outra é marcado por um jingle: "Vai pegar um GooGoo, é boooooom!"172 Passando pelo backstage, Tommy Brown e sua família não escutam o comentário que um membro da produção de Haven faz de sua apresentação ("Não vou nem dizer que você vai matá-los, pois eles já estão mortos"), nem a resposta de Haven: "Eles têm é sorte de estar vivos". Em outro ponto, Albuquerque, a principiante, consegue furar as primeiras barreiras do auditório, mas é detida no corredor que dá para os bastidores. Com a chegada de Connie White, ela tenta se misturar ao séquito da cantora famosa:

Albuquerque: Oh, é minha amiga Connie White.

Connie: Como é que vai, docinho?

\footnotetext{
${ }^{171}$ A imagem do voo dos pássaros como a figuração de um sonho de horizontes limitados já havia sido explorada por Altman em Voar é com os pássaros (Brewster McCloud, 1970). Naquele filme, um jovem vê seu projeto de realização pessoal (a construção de uma máquina voadora) ser literalmente esmagado quando lhe falta fôlego para suplantar o teto do Houston Astrodome, um ginásio de esportes. Daniel Caetano o descreve como um "diagnóstico severo" da suposta liberdade criativa alcançada pelos cineastas norte-americanos no início dos anos 1970: "Aqui, a ambição é livre, mas, para quem está fora da sociedade e não dialoga com seus pares, não resta caminho, senão falhar." CAETANO, Daniel. Circo dos sonhos. in: As Muitas Vidas de Robert Altman. Rio de Janeiro, São Paulo e Brasília: Centro Cultural Banco do Brasil, s.d. p. 92. Marcos Soares leva essa crítica adiante, apontando no filme uma crítica mais ampla dos limites da imaginação histórica, pois nem a revolução cinematográfica, nem a revolução social, "para as quais o país dava a impressão de estar preparado no começo dos anos 1970 foram muito além de limites bastante estreitos". SOARES, Marcos. Brewster McCloud and the limits of the historical imagination. in: ARMSTRONG, Rick (org.). Robert Altman: critical essays. p. 77.

172 "Go get a GooGoo, it's gooooood."
} 
Albuquerque: Você se lembra de ter assinado o meu disco?

Connie: Obrigada por ter vindo, querida. Obrigada por ter vindo ao show!

Albuquerque: Tem uma canção que eu escrevi...

Connie: Eu te ligo amanhã.

Com uma expressão facial que dá a entender nunca ter visto Albuquerque, Connie White se livra da mulher incômoda, deixando-a sozinha na luta para desvencilhar-se do guarda que a segura pelo braço. Enquanto espera a sua vez, a cantora ainda produz três sorrisos "plastificados", posando para os fotógrafos que a rodeiam.

Explorando o backstage, a narração "revira", mais uma vez, o tema das rupturas causadas pela modernização country na cidade. Os comentários de Haven e o produtor sublinham o quão predatória é a concorrência no ambiente profissional, desmentindo a liberdade gozosa dos voos solitários do "pássaro azul" que Tommy Brown acabara de cantar. Ao mesmo tempo, a captura que o "narrador" faz de frases aparentemente inconsequentes ("Você não precisa matá-los, pois eles já estão mortos") vai lançando os fios que, no acúmulo de cenas, sequências e quadros, constituem o pano de fundo histórico que ilumina o desfecho do filme: numa sociedade concorrencial violenta, quem está inserido no trabalho se conserva eliminando o outro, simbólica ou literalmente, de modo que o assassinato político passa a ser encarado como um desdobramento radical e espetacular da práxis social cotidiana.

O mapeamento desse ambiente de trabalho onde ninguém tem amigos, muito menos companheiros, tem continuidade no diálogo entre Connie White e Albuquerque. Recuperando a imagem do público impedido do contato com o artista, a narração volta a expor o profissionalismo country como uma operação de espetacularização, entendida como a ruptura de 
relações sociais e sua substituição por representações. Assim como o público de Barbara Jean no aeroporto, Albuquerque traz à memória uma interação mais próxima com o artista country, tratando a cantora famosa como amiga. Connie retribui o gesto, mas na chave da simulação, indicando ao guarda que a intrusa deve ser conduzida à plateia, lugar reservado aos seus espectadores. Seguindo a lógica apontada por Haven, Connie sabe que, num ambiente em que é preciso "matar" para conservar-se, a cantora principiante é uma concorrente potencial, uma consumidora ideal, mas nunca uma amiga. No seu gesto de sorrir mecanicamente para os fotógrafos, a personagem dá mais uma demonstração de seu aprendizado histórico; com a frieza e o aspecto posado de seu sorriso, Connie devolve à realidade social o mesmo tratamento que amoldou a sua maneira de agir.

O próximo a se apresentar no palco do Grand Ole Opry é Haven Hamilton. Enquanto baixa o pedestal do microfone deixado por Tommy Brown em pelo menos uns vinte centímetros, o cantor não escuta um comentário maldoso que Triplette faz sobre sua estatura. Colocando Triplette na posição de observador épico, o "narrador" troca de lugar com ele: se na festa era a narração que desmistificava Haven por meio da disposição dos atores no enquadramento, enquanto Triplette fingia adulação, agora é o personagem que, distanciado do centro da cena, sublinha, na pequenez do star pretencioso, o ridículo de seus delírios de poder. O trabalho de desmascaramento do personagem tem continuação na sua performance musical, em evidente contradição com sua imagem pública de "pai de família":

"Desfaça as malas e tente não chorar.

Não posso deixar minha mulher, por conta de três motivos:

Tem o Jimmy, a Cathy e a doce Lorelei. 
Por amor a meus filhos, devemos dizer adeus. ${ }^{173}$

"For the Sake of the Children", a canção de Haven, é mais uma das composições satíricas que Richard Baskin (Frog) produziu, com a intenção de criar contrapontos para as simulações das personagens. Enquanto fala de renúncia amorosa em favor das responsabilidades familiares, Haven é observado por Lady Pearl, sua amante (ou segunda esposa, não fica claro), e por Bud, o filho, cuja carreira musical ele podou, explorando-o como empregado de sua firma. A canção cumpre, portanto, a função épica de contradizer o enunciado do personagem, criando um hiato entre a autoimagem que ele se esforça por construir e o reverso desta imagem, figurado nas presenças de Pearl e Bud. "Keep Agoin", a canção seguinte, também foi composta por Richard Baskin; diferenciando-se dos jingles radiofônicos apenas quanto à sua duração, a música se oferece como um alívio compensatório aos sofrimentos dos ouvintes, elogiando o trabalho árduo como uma forma saudável de resignação: "Se o tempo ruim matar sua colheita, siga em frente/ É preciso trabalho para chegar ao topo, siga em frente. 174

Terminada sua apresentação, Haven ainda faz uso do microfone para justificar a ausência de Barbara Jean, hospitalizada, e anunciar Connie White como sua substituta. O cantor pede que o público mande "votos de melhoras" à estrela adoentada: "Espero que vocês enviem algumas cartas e orações a ela. O endereço é Vanderbilt Hospital, Nashville, Tennessee, 27322. Digam a ela que Haven Hamilton pediu para vocês escreverem." No meio da plateia genuína, um homem anota o endereço, claramente misturando ficção e realidade. Connie White entra em cena, mas, antes de começar a cantar, cumprimenta as crianças que vieram assistir ao show: "Eu quero que vocês estudem muito porque, lembrem-se bem, qualquer um de vocês pode tornar-se o presidente". A frase, que ecoa o otimismo ilusório do verso de Haven ("É

173 "Unpack your bags and try not to cry./ I can't leave my wife, there's three reasons why./ There's Jimmy and Cathy and sweet Lorelei./ For the sake of the children, we must say goodbye."

174 "If the weather kills your crop, keep agoin'/ It takes work to reach the top, keep agoin'." 
preciso trabalho para chegar ao topo, siga em frente"), não é bem recebida por Kenny, cuja expressão de ressentimento a narração vai buscar, no meio da plateia, em um contracampo da cantora. A mesma recepção negativa é sublinhada na reação de Kenny ao estribilho de "Memphis", canção de autoria da própria Karen Black (Connie White): "Eu não sei como são as coisas por lá [em Memphis], mas por aqui tudo vai ficando sombrio"175.

Uma das maiores conquistas da narração dialética em Nashville é a sua capacidade de produzir imagens do público, não como uma massa estática, mas como uma "vigésima-quinta personagem", que se constitui ao longo de um movimento contraditório sempre incompleto. Para alcançar tal efeito, foram essenciais tanto o modo como Altman efetuou o recorte e a montagem das imagens de espectadores quanto as estratégias adotadas para arregimentar as diferentes plateias que aparecem no filme. De equipes de figurantes, como na sequência do aeroporto, passando por grupos mesclados, como nos shows nos bares, a plateias genuínas, como na sequência final no Parthenon, Altman criou uma "paleta de fisionomias", com a qual pôde "pintar" o público como a mais dialética de suas personagens, como uma "personagem coletiva" por excelência. Na cena do Grand Ole Opry, a plateia é real e foi atraída ao teatro pela promessa de conhecer Henry Gibson e Lily Tomlin, atores relativamente populares à época, e pela chance de eventualmente ter seu rosto incorporado a um filme. A "falta de disciplina" da plateia real, que em outro tipo de produção seria vista como um perigo ao bom andamento das filmagens, é incorporada criticamente pelo trabalho de Altman, cuja montagem

"permite que os olhos de alguns curiosos desviem do palco e se fixem no verdadeiro show: as câmeras que os estão filmando. Dirigindo-se para a objetiva, os seus olhos fixos revelam tanto uma consciência de sua posição como parte da mercadoria quanto um fascínio [...] diante do espetáculo da indústria comercial que tanto apelo trouxe para os fãs de música country." 176

175 "I don't know what it's like out there, but in here it's getting darker."

${ }^{176}$ PECKNOLD, Diane. The Selling Sound. p. 234. 
"I Don't Know if I Found it in You", a próxima canção de Connie White, também composta por Karen Black, recupera o tema da renúncia amorosa sugerida por Haven em "For the Sake of the Children":

"Eu sei que você me ama quando estou feliz.

Eu sei que você me ama quando estou radiante.

Mas será que você vai me amar de manhã,

quando o bebê te acordar mais uma vez?"177

Embora as duas canções reforcem a uniformidade temática do country ao tratar de relações amorosas tradicionais, elas o fazem a partir de pontos de vista morais não alinhados com o conservadorismo típico do gênero: na primeira, o "eu-lírico" rompe uma relação extraconjugal em favor da família, o que, a despeito de reforçar a ideologia do "patriarcalismo responsável", não deixa de apontar que a renúncia "por amor aos filhos" é a negação do desejo; já na canção de Connie White, a incompatibilidade entre a família e o amor aparece na forma de uma dúvida. Diante das tarefas relacionadas à paternidade, o amor absoluto se relativiza e a amada desafia o amante com a pergunta que o desconcerta: "Mas será que você vai me amar de manhã, quando o bebê te acordar mais uma vez?" Desse modo, as duas canções desmascaram o romantismo country como uma barafunda de clichês sentimentais que não apenas falsifica a vivência amorosa das gerações revolucionadas pelos anos 1960, mas também se distancia da própria sexualidade conservadora de seu público mais assíduo.

Contudo, isso não impediu que a crítica mais apaixonada e zelosa de suas crenças reconfortantes encarasse o trabalho de desarme ideológico no filme como evidência de um ponto de vista esnobe, que não tem capacidade de compreender os sentimentos da gente simples:

\footnotetext{
177 "I know you love me when I'm happy./I know you love me when I shine./ But will you love me in the morning/ when the baby makes you get up one more time."
} 
"A música country é algo que pode devorar a derrota, o mau gosto e a pobreza de espírito, transformando-os em uma visão de mundo completamente nova, uma efetiva razão de viver. As paródias esfarrapadas que os atores de Altman cantam não são páreo para a força de uma canção como 'Não Largue Seu Homem' ['Stand By Your Man'], de Tammy Wynette [cantora que inspirou a personagem Connie White]. Do mesmo modo, filmes como Nashville e A Face in the Crowd não são capazes de captar a essência de nosso país, pois foram produzidos por sujeitos que não compreendem e nem querem compreender as vidas das pessoas comuns." 178

Finalmente, intercaladas às apresentações dos cantores, estão duas cenas paralelas. Na primeira, Sueleen ensaia, com o rádio sintonizado no Grand Ole Opry, o número que apresentará no evento para arrecadação de fundos de campanha, enquanto se arruma diante de uma penteadeira em que imagens de santos (uma Virgem Maria, um São Francisco, um pequeno oratório) se misturam a outros petrechos de beleza. Num quarto de hospital, Barbara Jean se irrita com o discurso de Haven no Grand Ole Opry, exigindo que Barnett, seu marido e empresário, desligue o rádio. Começa uma briga entre os dois e Barbara Jean tenta impedir o marido de ir ao King of Road, um bar de música ao vivo, agradecer a Connie White por tê-la substituído.

Ao serem mobilizadas como uma "costura formal" entre espaços cênicos não contíguos, criando uma triangulação entre o hospital, o quarto de Sueleen e o auditório do Grand Ole Opry, as "ondas do rádio" equivalem a uma "redução estrutural", na obra artística, do poder que as mediações técnicas das indústrias culturais têm na vida cotidiana. Como nos ensina Anselm Jappe, a propósito da crítica debordiana ao poder espetacular,

"Foi somente na época moderna que o Poder conseguiu acumular meios suficientes para não apenas instaurar uma dominação estendida a todos os aspectos da vida, mas também remodelar ativamente a sociedade segundo suas próprias exigências. Essa tarefa é cumprida por meio de uma produção material que tende a recriar,

178 YATES, John. Smart Man's Burden: Nashville, A Face in the Crowd, and Popular Culture. The Journal of Popular Film. p. 27. 
continuamente, tudo aquilo que engendra o isolamento e a separação, do automóvel à televisão." ${ }^{179}$

A figuração aqui é praticamente "uma coisa pela outra": o Grand Ole Opry permite ao "narrador" separar as personagens em três grupos, para depois reuni-las pela mediação do programa ao vivo. Com isso, o funcionamento social de um veículo como o rádio, isolando os sujeitos em suas casas para depois reuni-los na temporalidade da programação, é captado pela obra, passando a reger a montagem das cenas e a mixagem de som. Entretanto, na obra, esse funcionamento só é possível na medida em que ele se adapta ao meio fílmico: intercaladas na linearidade horizontal da montagem, as cenas exteriores ao auditório desmentem a temporalidade de um espetáculo que se pretende o mesmo em toda parte; a análise da trilha sonora desvenda a sua unidade como um simulacro resultante da manipulação do volume e da nitidez das canções e anúncios, apresentando-os em primeiro plano sonoro no auditório e como pano de fundo no hospital e no quarto, criando assim a ilusão de que se trata de uma transmissão simultânea nos três espaços. Por menos que estas manipulações estejam ressaltadas no discurso, a decomposição crítica da montagem as descobre como responsáveis pelo poder de cognição da arte: no seu esforço inglório de convencer que suas imitações da realidade cultural poderiam ser verdadeiras, a arte desmascara esta realidade, equiparando-a a si mesma, como trabalho de simulação. Nesse sentido, o gesto da personagem, exigindo que o rádio que a incomoda seja desligado, só pode revelar o quão frágil é a aparente implacabilidade deste poder que criou uma base técnica para o fingimento.

Terminada a discussão no hospital, Barnett sai dizendo que irá ao King of the Road, um bar com música ao vivo, onde espera encontrar os artistas e empresários que estiveram no Grand Ole Opry. A fala do personagem cria uma antecipação narrativa cuja resposta é a última sequência do quadro temático, situada naquele bar.

179 JAPPE, Anselm. Guy Debord. p. 26. 
Primeiro plano da entrada do King of the Road: no palco, Vassar Clements, um conhecido violinista bluegrass, demonstra virtuosismo em um solo de fiddle. Com a chegada de Julie Christie, de passagem pela cidade para a promoção de um filme, a narração insere mais uma estrela hollywoodiana no universo diegético. A aparição da atriz, assim como a de Elliot Gould na festa de Haven, tem função autorreferencial, pois os dois atores haviam protagonizado filmes recentes de Altman: Christie vivera a proprietária de um bordel em Onde os Homens são Homens (McCabe \& Mrs. Miller, 1971) e Gould, o detetive Phillip Marlow, de O Perigoso Adeus (The Long Goodbye, 1973). Julie Christie é apresentada a Connie White, que faz uma observação à atriz ("Você é inglesa, não é? Eu consegui notar"), e Haven Hamilton, que não se furta à tarefa de mencionar "as excelentes instalações para cinema que temos aqui em Nashville". Com a saída da atriz, os dois personagens conversam sobre a sua importância no mundo do show business:

Haven: Não é mesmo uma honra? Que surpresa! Julie Christie!

Connie: Quem é Julie Christie?

Haven: Quem é Julie Christie? Uma estrela famosa. Ela já até ganhou um Oscar.

Connie: (Rindo sarcasticamente, põe em dúvida as afirmações de Haven) $\mathrm{Ai}$, esse Haven é mesmo uma pérola! Mas tem um péssimo senso de humor. Oh, por favor, Haven! Essa daí não sabe nem pentear o cabelo!

A aparição de Christie no King of the Road arremata uma série de referências à indústria do cinema no quadro temático, transformando-o no mais ostensivamente "metafílmico" de Nashville: o cenário "bergmaniano" da casa de Haven, suscitando um comentário de Opal; as referências a Little Women e a Easy Rider, o mercado de celebridades trazido à tona nas referências ao Festival de Cannes e à premiação do Oscar; a pergunta do motorista ao star famoso ("O que o senhor está fazendo em Nashville"), suscitando uma leitura dupla (Nashville, a cidade, ou Nashville, o filme?); a 
alusão às instalações cinematográficas de Nashville. Entre as duas sequências que evocam o universo do cinema, está aquela dedicada ao Grand Ole Opry, cujo tema ostensivo é o rádio. Para costurar o conjunto, a narração utiliza o fio das relações entre política e show business: as negociações entre Haven e Triplette na festa; o adiamento da decisão de Haven para o Grand Ole Opry; a retomada do assunto, no King of the Road, em uma confissão apaixonada que Lady Pearl fará no prosseguimento da cena. Portanto, do ponto de vista formal, podemos dizer que este quadro temático "reveste" uma exposição das contradições da prática cultural do rádio country com a questão do culto aos stars cinematográficos, adotando a política como o elemento mediador entre os diversos ramos da indústria cultural representados: cinema, rádio, imprensa e música.

De um lado, o que se sublinha são as diferenças entre estes setores. Na superfície da paisagem, Opal reconhece as condições que dariam um ótimo filme de Bergman (“Isso é puro Bergman”), mas corrige a observação precipitada quando analisa os ocupantes deste espaço ("É claro que essa gente não tem nada a ver com Bergman"). A frase, que hoje pode soar banal, tem um sentido mais preciso no momento em que foi emitida (1974), quando chegava ao fim o período da '"Renascença Hollywoodiana' de 1967 1975, durante o qual, nas palavras de Michael Pye e Lynda Myles, a 'geração cinema invadiu Hollywood' e tentou criar um cinema de auteurs nos EUA, baseado no modelo europeu." ${ }^{180}$ Ao se mencionar Ingmar Bergman como uma referência inadequada para os EUA, a personagem serve de meio para uma avaliação da "Renascença Hollywoodiana". O trabalho de "alegorização" desse período histórico tem continuidade no aproveitamento crítico da fala improvisada por Lily Tomlin, no começo da festa, referindo-se aos jovens que copiaram a moda de Easy Rider (Dennis Hopper, 1969) - um marco da "Renascença Hollywoodiana" - e que por isso foram parar em uma enfermaria de hospital, "paralisados da cintura para baixo".

${ }^{180}$ COOK, David A. Lost Illusions. p. 71. 
Essa nota de ceticismo quanto à possibilidade do cinema autoral nos EUA é sublinhada pelo fato de o status estelar de Elliot Gould e Julie Christie não ser reconhecido pelas personagens no filme, exceção feita, é claro, à jornalista que precisa bajular celebridades para ganhar a vida. Ao colocar dois de seus colaboradores mais importantes na posição "incômoda" de "pessoas comuns" no interior do país, Altman faz, "escondido" pelo ponto de vista narrativo, o reconhecimento indireto do alcance de sua cinematografia no período da "Renascença", admitindo que, para muitos da "geração cinema", os efeitos da relativa liberdade criativa alcançada não foram muito além dos grandes centros urbanos.

Por outro lado, quando Haven oferece as instalações para filmagem em Nashville a Julie Christie, sem mencionar que a grande vantagem de se fazer cinema no Sul é evitar o ambiente sindicalizado de Hollywood, ele traz à tona uma aproximação, de outra ordem, entre cinema e indústria country, lançando luz sobre o lugar da produção de Nashville na "Renascença Hollywoodiana". Tendo sido inicialmente projetado como um musical para alavancar a carreira de Tom Jones e a gravadora da United Artists $^{181}$, Nashville acabou sendo financiado pela ABC, em troca dos direitos de transmissão em meio televisivo. A distribuição ficou por conta da Paramount, um estúdio tradicional que se colocara na vanguarda de uma tendência ao monopolismo em Hollywood, ao ser absorvido pela

"Gulf \& Western Industries, de Charles Bludhorn, em 1966. O conglomerado industrial, que Bludhorn desenvolveu praticamente sozinho, tinha um portfólio diverso que incluía mais de trezentas empresas subsidiárias na área de manufaturas, produtos agrícolas e bens de consumo, recursos naturais, vestuário, papel, materiais de construção, peças automotivas e serviços financeiros." ${ }^{182}$

Embora as diversas fusões significassem a perda de autonomia artística e econômica para este e outros estúdios, do ponto de vista

181 STUART, Jan. The Nashville Chronicles. p. 39.

${ }^{182}$ WYATT, Justin. High Concept. p. 70. 
da sobrevivência do negócio, elas foram benéficas, pois, na medida em que um estúdio deficitário era incorporado a um conglomerado, abria-se a possibilidade da "diversificação do risco" ao longo de um capital de base muito mais vasto e sólido. Do lado dos conglomerados, a baixa lucratividade dos estúdios era compensada por seus consideráveis ativos imobiliários e, principalmente, pela promessa de alimentação de seus braços televisivos pelas vastas cinematecas acumuladas ao longo de décadas. Embora não persiga o assunto, Justin Wyatt sugere uma relação direta entre as estratégias de negócios adotadas pelos estúdios e a pesquisa formal dos auteurs norte-americanos durante a vigência da "Renascença Hollywoodiana", a qual o autor qualifica como um período de "extensa experimentação de práticas industriais e de formas e conteúdos nos filmes"183. Neste sentido, a investigação estética dos auteurs foi, independentemente do grau de consciência dos artistas sobre sua prática, mais um campo para o desenvolvimento de produtos capazes de satisfazer um mercado de audiovisual crescentemente fragmentado.

Ao acumular referências a diferentes setores da indústria cultural (cinema, rádio, imprensa de celebridades, indústria fonográfica, música caipira, etc.), a narração transforma o presente quadro temático em um pequeno ensaio sobre as novas formas de produção cultural a partir de conglomerados. Se, na superfície ideológica, a rejeição dos profissionais country aos modos das estrelas de Hollywood sugere a pulverização da indústria cultural em setores antagônicos, no nível de seu funcionamento objetivo, estes setores comunicam-se e colaboram, encaminhando a sua tendência histórica à formação de blocos.

"Tudo está tão estreitamente justaposto que a concentração do espírito atinge um volume tal que Ihe permite passar por cima da linha de demarcação entre as diferentes firmas e setores técnicos. A unidade implacável da indústria cultural atesta a unidade em formação da política." 184

${ }^{183}$ WYATT, Justin. High Concept. p. 72

${ }^{184}$ ADORNO, Theodor W. \& HORKHEIMER, Max. Dialética do Esclarecimento. p. 115 - 116. 
Esta imagem apocalíptica de uma indústria cultural absolutamente unificada é rígida demais para algo que, naquele momento, ainda era uma tendência, não descrevendo com justeza o retrato produzido em Nashville de um funcionamento complementar, porém contraditório. Entretanto, o prognóstico político de Adorno e Horkheimer parece ressoar de modo incômodo na crítica que o filme vai tecendo.

Terminada esta pequena digressão, voltemos à cena. Em outro canto do bar, Bill conversa com Norman, seu motorista, sobre um possível caso extraconjugal de Mary, sua esposa. Connie White é convidada para subir ao palco para cantar com Vassar. A música escolhida é "Rolling Stone", outra composição da própria Karen Black. Mais uma vez, a letra fala de amores impossíveis, e agora também de sexo antes do casamento, delineando a coerência mercadológica do repertório da cantora que, invariavelmente trajando figurinos vermelhos e berrantes, se define como uma opção "mais quente" aos sentimentos ingênuos cantados pela doce e frágil Barbara Jean, sua rival:

"Você passeou comigo, doce Joshua, pela estrada do interior.

Você me levou, doce Joshua, para onde as rosas crescem mais altas.

Você se deitou comigo, Joshua, e me prometeu seu nome.

Mas depois disso, foi só isso, foi só isso. "185

A canção serve para que o "narrador" pontue o longo monólogo improvisado por Barbara Baxley (Lady Pearl), sublinhando algumas frases e dialogando com outras. Para facilitar a análise, reproduzimos, em um só texto, os fragmentos do monólogo, "disparado" por uma observação de Opal, ao reconhecer um broche de campanha na mesa de Lady Pearl:

185 "You walked me, sweet Joshua, down the country lane./ You brought me, sweet Joshua, where the roses grow so tall./ You laid me down, Joshua, and you promised me your name./ And after that, that was all, that was all." 
Opal: Olha, você tem um broche de Hal Phillip Walker. Não, não é de Walker, é de Kennedy! Mas isso não é coisa antiga? Eu pensei que ninguém no Sul tinha votado em Kennedy.

Pearl: (Emocionada) É de John Fitzgerald Kennedy. Bom, ele ganhou em todo o Sul, menos no Tennessee, na Flórida e em Kentucky. E tem uma razão por que ele não ganhou no Tennessee, mas ele levou 481.453 votos e o outro, o filho da mãe, levou 556.577 votos. (Começa a chorar). Agora, o problema que nós temos aqui é anticatolicismo. Esses tapados que vivem por aqui são todos batistas ou sei lá o quê, não sei. (Gagueja). Se até para ensiná-los a trocar dinheiro no bar, você tem que rachar o crânio deles, imagine então o que é preciso para ensiná-los a votar no católico, pela simples razão de que ele é o melhor candidato... E tudo de que eu me lembro nos dias seguintes foi que eu estava olhando para 0 aparelho de televisão e vendo tudo aquilo, vendo aquele xerife barrigudo dizer 'Ruby, seu filho da mãe' e Oswald e ela no seu tailleur cor de rosa... (Pearl chora e, fora do campo, o "narrador" Ihe dá uma resposta ambígua por meio do famoso provérbio que aconselha resignação, cantado no verso de Connie White: "Pedra que rola, pedra que rola, não cria limo"186). E aí veio Bobby. Oh, eu trabalhei tanto por ele. Trabalhei aqui, trabalhei em todo o país. Fiz campanha na Califórnia, em Stockton. Bobby veio aqui e falou aos eleitores, foi a Memphis e depois foi até mesmo a Stockton, Califórnia, e falou na antiga estação de trem de Santa Fé e no antigo depósito de Santa Fé. (Soluça). Oh, ele era um homem tão bonito. Ele não tinha o mesmo porte de John, você sabe, ele era mais franzino. (Na trilha sonora, sobe o volume da canção de Connie, cujos versos comentam as frases de Pearl sobre Robert, "Bobby", Kennedy: "Você partiu o coração dela, Joshua, como fez tantas outras vezes, mas um dia você vai entender essa dor,187) Mas, durante todo o tempo em que eu trabalhei para ele, eu senti tanto medo. Lá dentro, sabe? Eu senti tanto medo. (Fora do campo, o estribilho pontua o fim do monólogo: "Pedra que rola, pedra que rola, não cria limo").

Totalmente improvisado por Barbara Baxley, o monólogo de Pearl adiciona novas complicações à representação da contraditória situação política do Sul. Se, no Old Time Picking Parlor, já ficara sugerida a tinta racial da política sulista, agora é a questão religiosa que vem à tona na oposição entre católicos e batistas, reverberando ainda na série de assassinatos políticos que marcaram os anos 1960. O ex-presidente democrata John Fitzgerald Kennedy, assim como seu suposto assassino Lee Harvey

186 "Rolling stone, rolling stone, gathers no moss." 
Oswald e sua viúva Jacqueline Kennedy (a mulher no tailleur cor de rosa) são referidos na primeira parte do monólogo; a segunda é dedicada a Robert Francis Kennedy, irmão mais novo de JFK. Descrito como um "católico radical", "Bobby" Kennedy foi assassinado em 1968 por um árabe cristão palestino (Sirhan Bishara Sirhan), após vencer as primárias na Califórnia para a indicação do candidato democrata às eleições presidenciais, nas quais Pearl relata ter-se envolvido apaixonadamente. Ao tratar de Robert Kennedy, o monólogo "resvala" em um terceiro assassinato político com conotações religiosas - o do líder religioso e ativista pelos direitos civis, Martin Luther King, também em 1968 sobre o qual "Bobby" fizera um famoso discurso.

O fato de que seja Pearl, uma representante da elite empresarial de Nashville, a porta-voz do fervor católico-democrata no filme, problematiza a visão maniqueísta que associa este ponto de vista às classes subalternas e agrupa a oficialidade country em um bloco de posições ligadas ao Partido Republicano. Embora não se possa negar um fundo de verdade nessas associações correntes no discurso político da época, o monólogo composto por Barbara Baxley desautoriza a possibilidade de oposições binárias, fazendo jus ao fato de que as inclinações partidárias da música country

"sempre foram ambíguas. Artistas country fizeram campanhas para democratas, republicanos e populistas ao longo do século XX, [...]. Porém, foi somente a partir do momento em que [o segregacionista] George Wallace consistentemente mobilizou a música country e seus stars como apoiadores de suas campanhas ao governo [do Alabama, pelo Partido Democrata, em 1962] e à presidência [como candidato independente, em 1968] que este gênero musical passou a ser percebido como inerentemente conservador."

Em seu discurso, Pearl se ressente da violência que marcou os últimos anos da década ("Eu senti tanto medo"), mas não deixa de fazer um ataque aos "recalcitrantes", que se recusaram a votar no candidato recomendado pelas elites católicas:

187 "You broke her heart, Joshua, like so many times before, but some day you'll understand the pain."

${ }^{188}$ PECKNOLD, Diane. The Selling Sound. p. 218. 
"esses tapados que vivem por aqui são todos batistas [...]. Se até para ensiná-los a trocar dinheiro no bar, você tem que rachar o crânio deles, imagine então o que é preciso para ensiná-los a votar no católico, pela simples razão de que ele é o melhor candidato."

$\mathrm{Na}$ fala apaixonada da personagem, o encobrimento racial e religioso dos conflitos sociais nos EUA vai-se desmanchando e em seu lugar começamos a discernir uma imagem da luta de classes como um processo de violência física e discursiva: a mesma voz que transforma seu ponto de vista particular em uma premissa lógica, sugere "rachar o crânio" daqueles que não conseguem "ouvir a razão". Por meio desse nó ideológico, o espectador tem uma oportunidade de questionar "obviedades" da política norte-americana, tais como a crença de que é estrategicamente produtiva a aliança das forças progressistas do país com um partido como o Democrata, cujo "casamento de quarenta anos" com o sindicalismo "produziu uma classe trabalhadora alienada e politicamente desanimada."

Não apenas por tocar nas ações políticas radicais que marcaram os anos 1960, mas principalmente por se alinhar a uma série de pequenas representações de violência de classe, o monólogo elaborado por Barbara Baxley contribui para a criação de um pano de fundo histórico-social responsável pela coerência épica do assassinato político que fecha o filme. Esse aproveitamento de uma contribuição espontânea da atriz para o argumento geral do filme revela que o trabalho de Altman se equilibra em uma dialética de liberdade criativa quase absoluta, de um lado, com extremo rigor no aproveitamento dos materiais, do outro. De fato, como esclarece o próprio cineasta, o monólogo de Barbara Baxley foi bastante editado antes de incorporar-se à sequência:

"Nós deixamos a câmera ligada sobre ela até o filme acabar, carregando depois com mais um rolo, de modo que, no final, o monólogo durou vinte minutos.

${ }^{189}$ DAVIS, Mike. Prisoners of the American Dream. p. 101. 
Foi filmado de uma vez só, sem repetições, pois eu sabia que eu poderia remover qualquer pedaço mais tarde e saltar do monólogo para outros pontos da cena a qualquer momento."190

Esse tipo de trabalho, que diminui o controle no set para depois recuperá-lo em uma montagem intelectualmente rigorosa, desmente

"as censuras lançadas contra o diretor: 'preguiça', falta de rigor intelectual ou falatório incoerente [...]. Mas, em defesa de Altman, é importante notar que a articulação clara não é exatamente aquilo que ele procura: as extravagâncias de comportamento, a indulgência de certos temperamentos e a representação de encontros casuais podem ser incrivelmente expressivas, ainda que não resultem naquilo que os críticos chamam de 'totalidade orgânica'. Este tipo de crítica equivale a censurar um músico de jazz porque faltam a suas improvisações a forma polida e a execução de um músico clássico tocando a partir de uma partitura. Embora seja verdade que aquele alcançará uma forma acabada, há um tipo diferente de excitação na maneira que ele tenta atingi-la - uma maneira de encarar a 'forma' como um verbo em vez de substantivo, um processo, em vez de um postulado. E as bases estabelecidas por Altman para isolar e relacionar diferentes tipos e graus de coerência podem ser qualquer coisa, menos frouxas." 191

A comparação do trabalho de Altman com a improvisação do músico de jazz não poderia ser mais acertada: nos dois tipos de prática cultural, a liberdade e a espontaneidade do processo criativo se tornam possíveis justamente na medida em que estão sustentadas por uma técnica artística rigorosa ${ }^{192}$.

Os diversos cruzamentos entre indústria cultural, religiosidade, conflitos raciais e política, tecidos ao redor do Grand Ole Opry, têm continuidade no próximo quadro: uma espécie de "painel da adoração" na "cidade da música". A ligação entre as sequências se dá por meio do "gancho"

${ }^{190}$ STERRITT, David (ed.). Robert Altman: interviews. p. 23

191 ROSENBAUM, Jonathan. Improvisations and Interactions in Altmanville. in: Essential Cinema. p. $87-88$.

${ }^{192}$ A comparação feita por Rosenbaum foi originalmente publicada no número 44 da revista Sight and Sound, em 1975. Vinte anos depois, Altman exploraria as relações entre o jazz e seu próprio "fazer artístico", em Short Cuts - Cenas da Vida (1993) e em Kansas City (1996). Sobre este segundo filme, ver: TANAKA, Elder K. I. Jazz, indústria cultural e política em Kansas City, de Robert Altman, 2010 (dissertação de mestrado). 
temático deixado na conversa entre Bill e seu motorista, a respeito das suspeitas de um caso extraconjugal de Mary:

Bill: Eu acho que ela está tendo um caso.

Norman: Você está completamente por fora. Completamente por fora.

Da avaliação de Norman, a narração salta diretamente para uma tomada que a desmente.

Plano próximo de um sistema de som. Do lado direito do enquadramento, sobre uma mesa, a capa de um LP do trio Bill, Mary e Tom, com os nomes dos integrantes envolvidos por um coração estilizado, acentua, no plano da imagem, a sobreposição entre as relações profissionais dos três cantores e o triângulo amoroso que eles formam. Procurando as personagens que ocupam este cenário, um movimento panorâmico da câmera encontra Mary e Tom na cama, cobertos por um lençol branco. Abraçada ao corpo do amante, Mary diz, repetidas vezes: "Eu te amo, eu te amo, eu te amo". Tom dorme, mas sua voz gravada no disco que está tocando responde às declarações de Mary: "Esse lance que nós temos, por favor, não deixe ele mudar de direção./ Docinho,


revela a intervenção de um foco narrativo na cena, talvez com a intenção de sugerir que a "música industrializada", reproduzida no disco, vem trazer uma compensação ilusória para um problema de que ela é uma das causas: o empobrecimento da comunicação genuína entre os dois amantes que trabalharam juntos para produzi-la ${ }^{194}$.

\footnotetext{
193 "This thing we have, please don't let it drift away./ Honey, won't you let me be your friend?"

194 "Ao invés de entreter, parece que tal música contribui ainda mais para o emudecimento dos homens, para a morte da linguagem como expressão, para a incapacidade de comunicação. A música de entretenimento preenche os vazios do silêncio que se instalam entre as pessoas deformadas pelo medo, pelo cansaço e pela docilidade de escravos sem exigências. Assume ela em toda parte, e sem que se perceba, o trágico papel que lhe competia ao tempo e na situação específica do cinema mudo. A música de entretenimento serve ainda - e apenas - como fundo." ADORNO, Theodor W. O Fetichismo na Música e a Regressão da Audição. in: ADORNO, Theodor W., BENJAMIN, Walter et. al. Textos Escolhidos.p. 166.
} 
O abraço de Mary ao torso nu de Tom evoca uma imagem do Cristo morto, o que é reforçado quando a narração salta, diretamente, do rosto barbado do personagem e de sua música suave para um enorme vitral representando o "Cristo Pastor", em uma tomada contre-plongée "banhada" por um hino em latim. A passagem do quarto à igreja católica cria uma "ponte temporal" entre as atividades imediatamente posteriores ao programa de rádio e as "tarefas cristãs" da "cidade da música", mediando assim os dois polos antitéticos de uma cultura dividida entre "o hedonismo e a devoção religiosa (as exigências conflitantes do sábado à noite e do domingo de manhã)."195 Um movimento descendente da câmera percorre o vitral até concentrar-se sobre uma reprodução parcial do famoso versículo 16, do capítulo 10 ("O Bom Pastor") do Evangelho de João: "e haverá um só rebanho e um só pastor." O autoritarismo religioso por trás da frase bíblica se desdobra na sequência de montagem; do cantor no quarto até a última igreja que será mostrada, reitera-se a mesma fé cristã. Porém, o "olhar narrador" procurará também observar as diferenças raciais e sociais nos modos de professar a mesma fé.

Com exceção do colorido vitral do "Cristo Pastor", predominam na igreja católica os tons de marrom de uma "decoração" surpreendentemente espartana. Cantando no coral, Sueleen não é mais atormentada por suas dificuldades técnicas, soando afinada no conjunto de vozes. Esse efeito do canto coletivo sobre as idiossincrasias de Sueleen sugere uma determinação positiva do grupo social sobre o indivíduo, o que é ainda reforçado pela presença de sujeitos de diferentes classes (Pearl, Star e Wade) no mesmo espaço de adoração.

Uma interpretação que partisse apenas desses elementos diria que "cada uma dessas igrejas se afirma na tela como uma comunidade, um lugar onde a democratização do canto é possível, mesmo em

${ }^{195}$ MALONE, Bill C. Don't Get Above Your Raisin'. p. ix. 
Nashville, onde música é poder."196 Porém, como a narrativa dialética de Nashville nunca se fixa nas primeiras impressões, revirando continuamente seu objeto, a interpretação de uma "democracia musical" nos corais é desautorizada na próxima cena, tomada em uma igreja batista branca, em que se invertem alguns dos elementos apresentados na igreja católica, ao mesmo tempo em que outros são mantidos. A austeridade também domina a "decoração", mas não se expressa de forma empobrecida; muito pelo contrário, o que se vê agora é a exibição da riqueza em um altar acarpetado de vermelho onde um coral impecavelmente vestido entoa "Amazing Grace", um antigo hino anglicano, porém em uma versão modificada pela tradição afro-americana. $O$ tratamento que a narração dá à trilha sonora também diverge do anterior: em vez de uma massa cantando em uníssono, o volume ressaltado da voz de Haven no meio do coral o particulariza, em um efeito de "zoom sonoro", consonante com o plano próximo que vai buscá-lo no meio do grupo aparentemente homogêneo. A próxima cena, em uma igreja batista negra, recupera a "paleta de cores" da igreja católica, rebaixando-a um pouco mais, com tons de marrom e preto e uma iluminação econômica. As túnicas do coral são do mesmo feito daquelas usadas na igreja batista branca, porém, em cores divergentes: em vez do verde, a sobriedade do preto. A voz de Linnea, assim com a de Sueleen, é "diluída" no meio dos cantores negros, mas, uma voz masculina não identificada, é apresentada em "zoom sonoro", como o fora a de Haven. O refrão de "New-born again", o spiritual afro-americano que se executa, contradiz frases marcantes deixadas na narrativa até aqui; após ouvir que Nashville é uma cidade onde tudo precisa ser comprado ("Se ela quiser ouvir essa música, que compre o disco quando sair", diz Haven a Opal na sequência dos estúdios"), onde, segundo um trecho do discurso de Walker, "nada vem de graça", o espectador atento deverá suspeitar da promessa de "graça gratuita" ao pecadores, contida no canto dos fiéis batistas: "graça gratuita, graça gratuita, pecador./ Graça gratuita, graça gratuita, eu sou um recém-nascido outra vez."197

${ }^{196}$ KEYSSAR, Helene. Robert Altman's America. p. 156.

197 "Free grace, free grace, sinner,/Free, free grace, I'm newborn again." 
Esses espelhamentos e inversões entre as três igrejas sugerem formas contraditórias e combinadas de experiência religiosa, marcadas por diferenças de classe e raça, mas unificadas pela mesma fé cristã. A tradição afro-americana, simbolizada por Wade na igreja católica, referida indiretamente no hino com influência negra cantado na igreja batista branca e, finalmente, localizada no seu ponto nuclear na igreja batista negra, é o fio condutor de todo o grupo. Essa associação desmonta uma crença arraigada em uma "pureza racial" da cultura caipira na cidade. Como nos ensina Bill C. Malone,

"Americanos pobres - negros e brancos - encaravam-se com suspeita dos dois lados da divisão racial, mas trocaram estilos musicais desde praticamente seus primeiros encontros no Sul colonial. A partir desse cadinho de pobreza e de dor, negros e brancos criaram uma mistura de formas musicais que vieram a tornar-se os estilos populares nacionais mais importantes. Desta fusão de legados, a música country emergiu como a voz mais vital da classe trabalhadora sulista e como o barômetro das mudanças revolucionárias que presidiram a transição da vida rural para a vida urbano-industrial. Os músicos country herdaram de seus ancestrais britânicos o amor pela festa e pela dança, mas foi o contato sustentado com afro-americanos que os inspirou a experimentar novos ritmos e a cantar com intensidade gutural e expressão corporal acentuada."198

A cena que fecha o "painel da adoração" dá voz a essa ascendência não admitida na música country, trazendo Barbara Jean, a cantora branca mais querida da cidade, executando brilhantemente o spiritual afro-americano "In the Garden", na capela ecumênica do hospital. Vestindo roupa branca, presa sobre uma cadeira de rodas, fragilizada por suas enfermidades, a cantora tem a aparência espiritualizada de uma estátua sacra que se endereça a todas as devoções, funcionando como uma síntese das contradições apontadas até este momento da sequência. Entretanto, essa imagem, que poderia sugerir uma aposta da narração na possibilidade do convívio democrático em Nashville, é problematizada pelo fato de a capela ter sido ocupada pela cantora, uma celebridade comercial. Diante dessa ocupação,

${ }^{198}$ MALONE, Bill C. Don't Get Above your Rasin'. p. 14. 
surge uma pergunta: o espaço sagrado e a música religiosa bastam para assegurar a relação entre fiéis e ritual, ou a presença da cantora famosa contamina a relação, transformando o altar em palco, o ritual em espetáculo e os fiéis em plateia? O olhar apaixonado do soldado Kelly, fã de Barbara Jean, e a fruição distraída de Mr. Green, sugerem que a resposta se inclina para a segunda alternativa.

Evidentemente, é sempre possível argumentar que o espetáculo e o culto religioso nunca se estranharam, pois, como nos ensina Debord,

"O espetáculo é a reconstrução material da ilusão religiosa. A técnica espetacular não dissipou as nuvens religiosas em que os homens haviam colocado suas potencialidades, desligadas deles: ela apenas os ligou a uma base terrestre."199

Se é verdade que, enquanto "alienações objetivadas" das potencialidades dos homens que se voltam sobre eles na forma de um poder inescapável, os fetiches religiosos oferecem o modelo histórico para o autoritarismo das formas seculares de falsa representação, é preciso distinguir a religião de antes e depois das técnicas modernas de simulação, sem o quê o conceito de "espetáculo" perde a sua especificidade. Antes que a formamercadoria dominasse toda a vida social e o princípio da competição visando o lucro se impusesse a toda a produção cultural, inclusive nos rituais sagrados, as ilusões religiosas tinham

"como objetivo o encantamento, e não a diversão. Tal distinção é fundamental. Ao dotar objetos com poderes mágicos, o encantamento se torna o meio pelo qual ganhamos acesso ao sagrado. Já o entretenimento é o meio pelo qual nos distanciamos do sagrado."200

Ao emoldurar seu painel da experiência religiosa em Nashville com amálgamas de show business e imagens sacras - o corpo nu do cantor fundindo-se com o vitral do "Bom Pastor" no início e a "aura" de "santa

${ }^{199}$ DEBORD, Guy. A Sociedade do Espetáculo. Tese 20, p. 19. 
leiga" de Barbara Jean no final - pontuando o conjunto com a presença de celebridades nos rituais de cada igreja, a narração avalia como profundamente imbricada a relação entre a indústria fonográfica e o negócio de batismos, rezas e "resgate de almas" na cidade da música. Nesta troca, a indústria "requenta" o fascínio da religião e esta se deixa incorporar como um ramo do entretenimento.

De fato, como nos lembra Jan Stuart, Nashville não é apenas a Meca aonde se dirige toda sorte de peregrino no caminho do estrelato, mas é também a "cidade-fivela no cinturão bíblico" que tem registradas nada menos do que "oitocentas casas de adoração, duzentas e cinquenta das quais são protestantes."201 Embora Altman não tenha mantido a associação mais direta que o roteiro original de Joan Tewkesbury fazia entre o comércio religioso e o tema do assassinato político, mostrando Kenny, o assassino, em uma igreja em pleno Opryland ${ }^{202}$, um breve relato de Mr. Green na capela ecumênica, a respeito da morte de seu filho na Segunda Guerra Mundial, sugere que o espectador associe violência social e religião com a cantora que será assassinada:

"Sabe, Esther, minha esposa, está no mesmo andar que Barbara Jean no hospital. Ah, Esther e eu também tivemos um filho no serviço militar, não no exército, mas na marinha. Nós o perdemos no Pacífico Sul, não sabemos como. Foi na Segunda Guerra Mundial."

O relato de Mr. Green ao soldado Kelly, um ouvinte que está mais interessado no canto de Barbara Jean, são novas peças de um quebra-cabeça que a narração vai oferecendo, mas que é o espectador que deve montar: a combinação de fervor religioso, adoração pelas celebridades musicais, um processo político marcado por divisões irreconciliáveis, relações de trabalho tensionadas por uma competição predatória e a disponibilidade de armas de fogo ("Tenho duas armas aqui comigo", diz Pearl no Old Time Picking Parlor), vai criando um cenário no qual o gesto violento que conclui a trama não

${ }^{200}$ POSTMAN, Neil. Amusing Ourselves to Death. p. 122.

201 STUART, Jan. The Nashville Chronicles. p. $206-207$. 
apenas se torna historicamente verossímil como responde perfeitamente à lógica argumentativa construída pela narração.

Não há encadeamento narrativo entre este "painel da adoração" e o quadro seguinte, formado por duas sequências que tratam da relação da "cidade da música" com o automóvel. Em vez disso, a narração cria apenas "rimas" temáticas e visuais: a solenidade da capela ecumênica se desdobra naquela do monólogo de Opal na próxima tomada, comparando um ferro-velho a um cemitério sagrado; a fala de Mr. Green sobre a Segunda Guerra Mundial ecoa sobre as imagens de carros empilhados, formando uma simulação de um cenário de uma guerra em que os corpos das vítimas foram substituídos pelas "carcaças" dizimadas pela superprodução e pela obsolescência. Falando a um microfone ligado a um gravador, Opal prepara a narração de seu documentário sobre Nashville:

"Estou vagando por um cemitério. Os mortos aqui não trazem cruzes, tumbas ou coroas de flores para cantar suas glórias passadas, mas jazem apodrecendo, sobre montes decadentes e enferrujados, com suas entranhas arrancadas por mãos vorazes e carniceiras. As vastas expressões vazias de suas caveiras suspiram aos céus. A ferrugem sobre seus corpos é a cor do sangue coagulado. Sangue seco. Penso em um cemitério secreto de elefantes. Sim, cet air de mystère, cette essence de l'irréel! Estes carros estão tentando se comunicar."

Debaixo de um túnel formado pelos carros empilhados, sai Kenny, revirando peças velhas, talvez à procura de alguma que o ajude a reparar o automóvel que abandonara na autoestrada. A princípio, sua presença não é notada pela jornalista.

Opal: Oh, carros! Vocês estão querendo me dizer algo? Estão querendo transmitir algum significado?

Kenny: Como é que é? Não ouvi.

${ }^{202}$ TEWKESBURY, Joan. Nashville. p. $75-76$. 
Opal: Ai, perdão! Eu pensei que estava completamente sozinha. Que vergonha! Oh, você é músico!

No "monólogo do ferro-velho", a caracterização de Opal alcança uma síntese. Principal representante da classe intelectual no filme, a personagem vinha sendo traçada como uma burocrata subempregada, contando com poucos meios para a realização de seu trabalho, acesso restrito à matéria social de seu documentário, mas muita disposição para produzir um diagnóstico profundo da "América" a partir da "cidade da música". Na fala gravada para um filme que dificilmente se realizará, a "falsa liberdade" do trabalho precário (que não está atrelado a meios de produção) é traduzida na "livre-associação" de interpretações, passando da crítica estética a delírios metafísicos, em um idioma que transita entre o inglês britânico e o francês, tão na moda, à época. Por não ter um compromisso claro com ninguém (nunca se sabe se ela é, de fato, uma funcionária da $\mathrm{BBC}$ ), a personagem tem liberdade de dizer aquilo que deseja; por esse mesmo motivo, ela só pode dizê-lo a si mesma. Falando ao gravador, ela é, no limite, a única ouvinte de um discurso tautológico que volta ao próprio emissor. Porém, como em Nashville nada é exatamente aquilo que parece ser, no meio da plateia silenciosa formada pelas "carcaças" de automóveis, surge um único ouvinte para esta fala lançada ao vento: Kenny, o sujeito que veio atrás do político pseudorradical e que terminará assassinando a cantora mais querida da cidade.

"O paralelo entre o documentário em processo de Opal e o projeto do próprio filme não é acidental. Joan Tewkesbury, a roteirista de Nashville, criou em Opal um reflexo ambivalente de seu papel, assim como o de Altman, como críticos sociais. Nas palavras do próprio Altman, 'era para Opal representar a nós dois... forasteiros cheios de pose'. Ao longo do filme, ela se esmera no esforço de transformar Nashville em uma metáfora ampliada do consumismo americano, um processo que chega ao zênite na cena em que ela vaga por um ferro-velho, ditando uma elegia hilariantemente melodramática aos carros que ali jazem apodrecendo, sobre montes decadentes e enferrujados, com suas entranhas arrancadas por mãos vorazes e carniceiras'. Embora ali ela peça que os carros lhe contem sua história [...], no resto do filme ela não deixa ninguém falar [...]. Ao identificar-se com Opal e seus 'comentários 
intelectualizados e pseudocompassivos sobre a terra americana devastada', Altman e Tewkesbury põem em questão a própria crítica que Nashville parecia suscitar."203

O monólogo foi composto por Geraldine Chaplin, a atriz que interpreta Opal, assim como também o foi a maior parte de suas falas. De fato, quando se observam as ações da personagem e aquilo que ela diz, nota-se uma semelhança muito maior com Geraldine Chaplin do que com Altman e Tewkesbury. Inglesa de passagem por Nashville, falante de alemão e francês, conhecedora dos auteurs europeus e praticante do cinéma vérité, exmilitante de esquerda com passagens pela África e Israel ("Eu tinha uma atitude muito romântica em relação àquele tipo de socialismo", diz a personagem, sobre sua experiência em um kibutz); todas essas características aproximam a personagem de clichês do artista/intelectual pós-moderno, com trânsito mundial, fruto da internacionalização da produção cultural a partir dos anos 1970. Quando se pensa na biografia de Chaplin - norte-americana, filha de um artista émigré de esquerda, à época casada com um cineasta espanhol e já se encaminhando para uma carreira divida entre a Europa e os EUA - nota-se que não faltaram à atriz elementos para compor sua personagem e entende-se por que ela figurou com tanta exatidão os processos de desmanche do trabalho artístico no momento em que as indústrias culturais começavam a "fugir" dos ambientes excessivamente sindicalizados nos EUA e a procurar locais mais propícios à saúde dos negócios, não apenas no sul do país, mas também fora dele, na produção que já apontava para um mercado global.

Um corte abrupto na imagem transporta o "olhar narrador" direto para o autódromo da cidade, onde uma prova de NASCAR está em curso. Fundada em 1948, a "National Association for Stock Car Racing" (NASCAR) promove o espetáculo esportivo com o segundo melhor índice de audiência televisiva nos EUA, atrás apenas do futebol americano. Assim como a indústria do country, que passava por uma modernização naquele início de anos 1970, as corridas promovidas pela NASCAR entravam também em sua "era

${ }^{203}$ PECKNOLD, Diane. The Selling Sound. p. 230. 
moderna", após acolherem, desde 1972, patrocinadores tais como a fabricante de cigarros R.J. Reynolds Tobacco Company, impedidos de anunciar seus produtos, diretamente, na televisão. É o ronco dos motores "envenenados" dos "stock cars", carros de passeio adaptados para o automobilismo, que rompe o silêncio deixado pelo monólogo de Opal.

Numa "ilha" no meio do circuito oval, uma espécie de concurso de calouros está em andamento. Uma principiante tenta cantar "It Don’t Worry Me", mas quase não chega a fazer-se ouvir acima do ruído dos carros. Quem a acompanha ao violão é Frog, que dá mais um passo em sua trajetória descendente na "Music City": demitido do posto de pianista no estúdio de Haven, o personagem ainda trabalhou como "fundo musical" para principiantes no Deemen's Den antes de chegar à situação presente, em que sua arte mal consegue competir com o barulho da corrida. Em uma passagem pelos boxes do autódromo, a narração se concentra em dois automóveis que exibem as marcas de Haven Hamilton e Tommy Brown. Na arquibancada, os dois músicos-patrocinadores assistem ao espetáculo ao lado de suas famílias. Desempacotando um verdadeiro piquenique, Haven oferece um pedaço de melancia a Tommy Brown, sendo imediatamente repreendido por Lady Pearl. No palco improvisado no meio do circuito, é a vez de Albuquerque tentar a sorte. Reconhecendo a própria incapacidade de competir com os carros, ela anuncia: "O próximo número é com gestos apenas."

Ao reunir cantores profissionais e amadores no universo da corrida de NASCAR, a narração expõe o funcionamento combinado dos dois passatempos prediletos da classe trabalhadora branca sulista: música country e automobilismo. Chama a atenção o patrocínio de duas equipes pelas marcas pessoais de Haven Hamilton e Tommy Brown, sublinhando o funcionamento simbiótico entre os dois ramos do entretenimento: a corrida se alimenta do capital trazido pelos cantores e o retroalimenta valorizando as marcas expostas, continuamente, no espetáculo reiterativo do circuito oval. Neste universo em que a arte deixou de ser uma questão relevante e os 
cantores podem sentar-se confortavelmente na arquibancada, enquanto seus "nomes de marca" prosseguem a sua valorização na corrida circular, a associação com o comercialismo já não envergonha o artista.

De fato, em toda a cena, o domínio do comercialismo sobre a arte, do dinheiro sobre o trabalho, do que é morto sobre o que é vivo, é aparentemente celebrado com um sinal do vigor e da recente afluência do Sul. Em um ambiente de competição acirrada e de extrema volatilidade, bem figurado nas rivalidades pessoais e no constante incremento de amadores, engrossando o exército de reserva na cidade, os stars da música oferecem uma experiência cultural previsível e segura, codificada em suas respectivas "imagens de marca". Ao longo do filme, vão sendo demonstrados os processos de constituição destas marcas: escolha de figurino, declarações públicas bem planejadas e segmentação de mercado. Uma vez definida a marca, a sua valorização depende do grau de reconhecimento público que ela alcança; é a esta necessidade que NASCAR, um espetáculo de massas com alcance nacional, vem responder, tornando-se um colaborador dileto da indústria country.

Se a narração se limitasse a constatar essa simbiose, a cena não iria muito além da representação de um "caso de sucesso". Porém, a composição dialética de Nashville não se deixa fixar em um lado apenas do problema, tentando desencavar as suas contradições. A impressão inicial de que o patrocínio de equipes automobilísticas pode aliviar a concorrência violenta entre os cantores, transferindo suas rivalidades para a arena esportiva, é desmanchada pela brincadeira racista de Haven. Ao oferecer a Tommy Brown um pedaço de melancia, fruta que aparece como o objeto de desejo de negros nas piadas racistas que se contam nos EUA, Haven faz um ataque público ao rival na música, indiretamente tocando nas concessões morais, humilhações e pequenas ou grandes exclusões, escondidas na vida social recoberta de imagens valorizadas. 
No plano da forma, o mesmo tipo de violência é trazido pelo desequilíbrio na relação entre voz e ruído na trilha sonora. Se um dos traços de "humanidade" do cinema sonoro é o fato de ele privilegiar "a voz, sublinhando-a e separando-a de outros sons" ${ }^{204}$, esse quadro temático inverte a relação, jogando a voz para o segundo plano e trazendo os ruídos para uma posição de destaque na trilha; Opal fala a um gravador, diante de uma "plateia" de carros sucateados, a principiante não consegue impor-se sobre o ronco dos motores e Albuquerque desiste de competir com as máquinas, fazendo um show silencioso, "com gestos apenas". Por meio desse desequilíbrio das prioridades na trilha sonora, a narração aponta o processo de "coisificação" das pessoas e de "humanização" das máquinas numa sociedade em que o trabalho que valoriza o capital (ou as marcas que o representam) não pode pautar-se pela realização humana.

$\mathrm{Na}$ sua origem, o esporte foi uma estilização de gestos retirados do universo do trabalho, preparando sua incorporação a uma atividade lúdica ${ }^{205}$; desta origem até o automobilismo, as práticas esportivas passaram por modificações de toda sorte, incluindo aí sua transformação em espetáculo e consequente absorção pelo show business. Porém, se a carga genética do esporte não tiver sido completamente eliminada nesse caminho, então o automobilismo pode ser também uma estilização de "gestos" do trabalho, não na sua forma antiga, mas nas suas formas contemporâneas ${ }^{206}$ : a

\footnotetext{
${ }^{204}$ CHION, Michel. Audio-Vision. p. 5.

205 "Ao moverem-se para dentro da cidade, os residentes urbanos haviam deixado para trás muitos e saudáveis passatempos rurais, além de ocupações corporais vigorosas: assim, era missão dos jogos olímpicos trazer de volta tais virtudes rurais como parte da rotina urbana diária - exercícios estilizados e autônomos, moldados a partir de uma matriz retirada da lavoura, do pastoreio e da caçada." MUMFORD, Lewis. The City in History. p. 139. Neste ponto de seu relato sobre a passagem da sociedade rural para a cultura urbana na Grécia antiga, Lewis Mumford não trata da questão da escravidão; porém, talvez fosse o caso de especular que o esporte, enquanto "trabalho estilizado" para o exercício do corpo, possa ter sido uma forma de ocupar o tempo ocioso de que as classes dominantes viriam a gozar na pólis escravista e um acesso indireto ao trabalho, não como meio de ganhar o sustento, mas como uma atividade vital do ser humano.

${ }^{206}$ De fato, como nos ensina Alexandre F. Vaz, a partir dos anos 1960, os espetáculos esportivos não apenas figuram o trabalho, mas também compõem um setor estratégico do desenvolvimento econômico e científico disparado pela competição entre potências mundiais durante a Guerra Fria: "Muito em função dessa disputa, o treinamento desportivo desenvolveu-se
} 
substituição do homem pela máquina na arena esportiva; os giros tautológicos em um circuito repetitivo, cujo vencedor efetivo é o capital; a personalidade do trabalhador cultural sendo plasmada em um "nome de marca"; a transformação deste trabalhador em espectador de abstrações de si mesmo. Assim,

"As imagens que se destacaram de cada aspecto da vida fundem-se num fluxo comum, no qual a unidade dessa mesma vida já não pode ser restabelecida. A realidade considerada parcialmente apresenta-se em sua própria unidade geral como um pseudomundo à parte, objeto de mera contemplação. A especialização das imagens do mundo se realiza no mundo da imagem autonomizada, no qual o mentiroso mentiu para si mesmo. O espetáculo em geral, como inversão concreta da vida, é o movimento autônomo do não vivo."207

As contradições das formas contemporâneas do trabalho se reproduzem no tempo livre e o esporte de espectador se revela como um campo de treinamento para a adaptação a essas formas. Em um mundo dominado pelas coisas, o "não vivo" (o capital, a marca publicitária, a imagem valorizada) domina o que é vivo (o trabalho, o cantor conduzido à posição de espectador, os amadores que não conseguem competir com o ruído dos motores). Opal "espiritualiza" os automóveis ao verbalizar as "angústias existenciais" da sucata no ferro-velho, enquanto Albuquerque é reduzida à pura "materialidade" do gesto, em seu número silenciado pelos giros das equipes. Nestas inversões, descobrimos que o "mentiroso mentiu para si mesmo": a marca, o fetiche, a ilusão materializada, que se desprendeu do cantor para representá-lo na competição acirrada pela atenção pública, aponta para a própria situação desfavorável daquele de quem ela se desprendeu; em um espelhamento com sua marca, o cantor corre o risco de se tornar tão banalizado quanto seu nome, girando no espetáculo repetitivo do circuito oval. $\mathrm{Na}$ montagem dialética entre as duas cenas, a narração aponta para o destino final

de forma espantosa, levando os resultados a patamares não imaginados e também a um incremento maciço dos procedimentos de doping. Correspondente a esta tecnologização da performance foi a reprodução e disseminação das imagens esportivas, que possibilitaram às décadas posteriores o crescente investimento na transmissão em tempo real dos espetáculos esportivos." VAZ, Alexandre F. Teoria Crítica do Esporte: desdobramentos, críticas e possível atualidade. p. 1. 
de sua "arte" vendida: a obsolescência e o descarte na mesma pilha aonde foram parar os carros imprestáveis, "exauridos" de qualquer utilidade anterior.

O corte abrupto entre este grupo temático e o seguinte indica um salto temporal e espacial no nível do encadeamento narrativo, mas, no que tange à exposição do universo de relações produtivas em Nashville, é possível falar de continuidade. O tema das relações entre tempo livre e trabalho, que vinha sendo "revirado" desde a sequência dos amadores nos bares de música ao vivo, passando pelo programa de rádio e pelo espetáculo automobilístico, alcança um momento de síntese na justaposição entre duas sequências que sublinham a funcionalidade e a disfuncionalidade de relações amorosas como complemento de relações profissionais.

A primeira sequência se passa no quarto de hotel de Bill e Mary. O encarceramento do casal em um relacionamento que, para sustentar-se, passou a depender da empresa familiar, é elaborado formalmente na composição visual do cenário: as "barras verticais" de diferentes cores, compondo as paredes e as portas do quarto, evocam grades de uma cela; ao mesmo tempo, o acúmulo de restos de mercadorias, roupas sujas, copos vazios e outros objetos que dificultam a mobilidade, alude às dificuldades de se desfazer uma relação amorosa em que investimentos de capital, compromissos de trabalho e sentimentos se misturaram a ponto de não poderem mais ser discriminados.

É de manhã e Bill tem uma expressão de preocupação, como se a conversa da noite anterior, sobre o suposto affair de Mary, se desdobrasse em novas indagações. Irritado, ele acorda a esposa e exige explicações sobre onde ela passou a noite. A cena clássica de briga de casal se desenvolve até o clímax tradicional: a ruptura do laço amoroso. Enquanto Mary esvazia gavetas, para ir embora ou para expulsar Bill, não se sabe ao certo, a campainha toca. Trata-se de Triplette, o marqueteiro de Walker,

${ }^{207}$ DEBORD, Guy. A Sociedade do Espetáculo. Tese 2, p. 13. 
que traz uma proposta irrecusável para a banda "Tom, Bill \& Mary": uma apresentação paga no comício, seguida de publicidade gratuita durante toda a campanha, já que o evento será filmado e usado em anúncios na televisão. Mary faz uma objeção: os três membros da banda são "Democratas Registrados" e não poderiam votar em um candidato que, além de representar um partido novo, ela acha "meio doido". Triplette resolve a questão lembrando que, nos dias de hoje, todo mundo é "meio doido". Quanto à afiliação partidária, o marqueteiro relativiza o problema, lembrando que ele próprio é um "Democrata Registrado", o que não o impede de trabalhar para Walker.

Este apagamento das distinções partidárias pretendido pelo personagem transporta, para o campo político, o esboroamento de toda discriminação estética que a indústria country operava no ramo da produção musical: assim como a oficialidade country exigia o direito de validar culturalmente seus produtos segundo o critério da eficácia comercial, Triplette propõe um jogo político em que o valor de possíveis afiliações seja medido apenas por sua capacidade de gerar ganho econômico. No final, é a necessidade de promover a banda, quer dizer, de reforçar o laço profissional, que determina a aceitação da oferta de trabalho.

A cena toda expõe a ruptura de antigas alianças e a nova coesão trazida pelo assédio da política aliada à produção cultural. $O$ rompimento definitivo é figurado em dois impasses: a afiliação à plataforma democrata impede a aceitação de trabalho na campanha de Walker, de modo que ou a inclinação partidária ou a oportunidade de promoção da banda deve ser abandonada. O mesmo vale para o laço afetivo que unia o casal até este ponto: ou se elimina Tom, terceiro elemento da banda e do triângulo amoroso, desmanchando os negócios para "salvar o amor", ou se acolhem as relações extraconjugais como um elemento necessário ao bom funcionamento da banda "Tom, Bill \& Mary". A chegada de Triplette, representante dos novos acordos entre capital, política e trabalho, vem resolver este problema, costurando as falhas abertas nas relações: ao inverter as prioridades, colocando a manutenção 
e a valorização da banda em primeiro lugar, as afiliações políticas perdem força e podem ser substituídas por outras, enquanto as relações privadas (o casamento, a amizade) se solidificam pelo reforço do laço profissional. Neste novo arranjo, é possível mesmo que o triângulo amoroso deixe de ser uma relação "anômala" para ser aquela que melhor acomoda as necessidades afetivas e profissionais de uma banda composta por três.

A contaminação da vida privada pelas funções produtivas do espetáculo tem continuidade em uma sequência que se passa no quarto de hotel de Tom. A reiteração do espaço cênico (mais um quarto de hotel) delineia a relação transitória que as personagens têm com a cidade da música; poucas são as que vivem em Nashville, e a maioria apenas se serve de seus atrativos industriais, para abandoná-la em seguida. No espelho sobre a penteadeira, alguém escreveu "eu te amo", com batom; supõe-se que a autora da declaração seja Mary, que havia dito as mesmas palavras, em uma cena anterior, naquele mesmo espaço. Tom trabalha, ensaiando um número musical no violão, mas a atividade parece aborrecê-lo a ponto de não conseguir continuar. Buscando uma solução que o ajude a prosseguir, o personagem pede uma droga forte a Norman, o motorista, mas este só pode Ihe oferecer maconha. Tom então se levanta e telefona a uma mulher, com quem marca um encontro sexual.

A troca da droga alucinógena pela mulher do outro lado da linha sugere uma complementaridade funcional entre o uso de psicotrópicos e o sexo na conservação de Tom para o tipo de trabalho que ele exerce. Ambas as atividades destinam-se a preencher uma espécie de "tédio existencial", exibido no aspecto geral do personagem, e a tornar suportáveis a carga e a forma do trabalho na indústria da música. A mulher a quem Tom telefona não é nenhuma daquelas a quem a narração já o relacionara, sugerindo que o personagem não é o vértice fixo de um único triângulo amoroso, mas uma espécie de ponto em deslocamento, cuja conservação exige que ele crie novas triangulações, em um movimento incessante. Se a eficiência exibida por essas 
triangulações, na conservação produtiva de Tom, pode ser lida como uma prova da autossustentabilidade do star system de Nashville, a tautologia de seu movimento escancara os limites lógicos do sistema de produção subjetivado pelo cantor: o corpo que se mantém produtivo no acúmulo de psicotrópicos e de sexo pede sempre uma droga mais forte e uma mulher mais excitante, o que, numa trajetória ascendente, ameaça consumir o próprio corpo; de forma análoga, o modo de produção que abranda suas "crises existenciais" recorrentes com os paliativos de sempre, apenas adia o enfrentamento de sua crise derradeira.

No meio dos quadros temáticos, surge uma cena autônoma, relacionada ao grupo anterior apenas formalmente, por uma espécie de "eco": inicialmente não reconhecendo a voz de Tom, a mulher do outro lado da conexão telefônica pensou que o star fosse uma testemunha de Jeová fazendo proselitismo. Na cena seguinte, a montagem nos transporta para uma tomada em frente ao comitê de campanha de Walker, para onde seu "furgão falante" retorna, depois de mais um dia de trabalho. Na trilha sonora, é exposto um trecho do discurso do candidato, defendendo a taxação dos investimentos corporativos das igrejas. Em frente ao portão, destaca-se a presença de Kenny, olhando, de forma suspeita, para os cartazes colados na parede. Um plano de detalhe da caixa do violino de Kenny aumenta a suspeita e fecha a sequência, associando de vez a figura do assassino político ao tema da religião e da candidatura manipuladora de Walker.

Por meio de mais um salto na montagem, a narração faz um deslocamento temporal, da tomada do comitê de campanha, à noite, para um estacionamento repleto de ônibus escolares, de dia. Circulando entre os ônibus, Opal registra outro monólogo que, no seu aspecto formal, não difere muito daquele proferido no ferro-velho. Aqui também sua tentativa de produzir uma interpretação esclarecedora da realidade norte-americana esbarra na precariedade de seu trabalho de documentarista, cujo único instrumento de 
produção é um gravador e cujo repertório teórico-descritivo não se adéqua à matéria diante dela, tendo de passar por sucessivas reformulações:

"Os ônibus, os ônibus estão vazios e me olham de modo quase ameaçador, desafiador, como os olhos de tantos dragões amarelos vigiando-me com seus olhos vagos e ocos. Eu me pergunto quantas criancinhas negras e brancas têm pesadelos amarelos, sua própria forma especial de medo do perigo amarelo... Acho que não vai dar, não posso começar... Droga! Tinha que ficar mais... positivo. Não, mais negativo. Começando de novo: amarelo é a cor do perigo. Não. Amarela é a luz do sol e, ainda assim, eu vejo muito pouca luz nas vidas de todas as criancinhas negras e brancas. Em vez disso, o que eu vejo é um estudo em cinza, uma mistura de preto e... Ai, meu Deus, isso ficou fascista! Oh! Amarelo, amarelo, amarelo, febre amarela!'

Neste segundo monólogo, é possível notar o funcionamento da dialética do trabalho intelectual que, mesmo quando realizado em condições precárias, eventualmente produz conhecimento sobre a matéria social com que depara. Ao "jogar", de maneira mais ou menos inconsequente, com o significado do "amarelo", inspirada pela cor dos ônibus escolares, a documentarista involuntariamente toca no tema da reestruturação da economia norte-americana nos anos 1970 em direção a uma produção pós-fordista (terceirizada, desregulada, financeirizada), unindo, na mesma imagem sintética do "medo amarelo", dois elementos não imediatamente relacionados pelo senso comum: a Guerra do Vietnã e a invasão do mercado norte-americano por produtos manufaturados na Ásia, sobretudo no Japão. Independentemente das intenções de Opal, termos como "dragões amarelos", "olhos ocos" e "a luz do sol" evocam imagens dos países do extremo oriente, e termos como "ameaçador", "desafiador", "pesadelo amarelo", "perigo amarelo" e "febre amarela" dão o tom da recepção da imagem desses países nos EUA naquele momento histórico.

O interessante aqui é a possibilidade de juntar as duas referências: se o "medo amarelo" da política externa norte-americana era um Vietnã sob controle da URSS, o "perigo amarelo" da balança comercial do país vinha na forma da importação de televisores, câmeras fotográficas e outras 
engenhocas tecnológicas, do Japão, combinada a uma crescente desconfiança internacional em relação ao dólar. Não casualmente, esses "inimigos" contribuíram para medidas econômicas que alteraram a estrutura produtiva norte-americana, desmanchando uma série de garantias que o trabalho tinha até então ${ }^{208}$. A necessidade de se recuperar dos gastos na campanha fracassada do Vietnã e de aumentar a competitividade do produto norte-americano frente à "ameaça amarela", visando à construção de uma "Nova Maioria" para a campanha à reeleição em 1972, serviu de desculpa para azeitar a aprovação de uma série de medidas contra o trabalho: arrocho salarial, terceirização, revogação de direitos, etc. Ao prever um futuro "cinzento" para as criancinhas negras e brancas nascidas entre as décadas de 1960 e 1970, o discurso de Opal acerta não apenas em seu diagnóstico, mas faz também um prognóstico válido para o momento atual.

Este tipo de uso irônico de falas improvisadas pelos atores nem sempre foi bem visto pela crítica. Em um artigo publicado à época do lançamento de Nashville, Steven Abrahams afirma que

"A estrutura do filme cria uma inconsistência em que a caracterização varia do crível a retratos simpáticos e evidentes caricaturas (caso de Opal, da BBC, interpretada por Geraldine Chaplin). Ao transferir para atores e atrizes uma boa parte do controle sobre suas personagens, o processo de Altman abre novos campos para a criatividade, mas também obscurece as intenções gerais do filme. Devemos analisar as personagens em relação a seus papéis no mundo da música e da política ou devemos aplaudir os atores por trás

208 "Duas crises diferentes convergiram para as medidas tomadas em Camp David em agosto de 1971. A primeira foi o colapso do apoio doméstico à política do gradualismo. A segunda foi o colapso da confiança externa no dólar, juntamente com o primeiro déficit na balança comercial dos EUA desde 1893. Embora tivessem histórias distintas, as duas crises proporcionaram a Nixon a oportunidade de usurpar o tema da economia da plataforma democrata antes das eleições presidenciais de 1972. No contexto doméstico, ele 'turbinaria' a economia segurando os controles. No campo externo, lançaria uma cruzada de exportação visando a criar empregos para os norte-americanos em detrimento dos aliados da América. Influenciado por John Connally, o presidente abraçaria um paradigma mercantilista que subordinava questões monetárias e de comércio exterior a seus propósitos políticos domésticos, dentre os quais estava a criação de uma Nova Maioria. Com sua candura costumeira, Connally resumiu o sentimento nacionalista que tomaria conta da administração do país no ano de Camp David. 'Minha abordagem básica é que estes estrangeiros estão querendo nos ferrar', Connally disse a um grupo de consultores do Tesouro. 'Nosso trabalho é ferrá-los primeiro." MATUSOW, Allen J. Nixon's Economy. p. 117. 
delas? Claramente, Altman busca os dois objetivos, mas, no final, se mostra mais comprometido com o entretenimento do que com a análise. [...]. Por não fazer um esforço consistente na direção da paródia ou da análise, Nashville nos mantém em um nível experiencial em que mitos e meias-verdades sobre a cultura popular são reforçados, em vez de serem sistematicamente questionados."209

É possível que, ao exigir "organicidade" de Nashville, Abrahams demonstre apenas sua incapacidade de identificar o princípio de construção do filme: a montagem. Porém, tampouco se pode descartar a possibilidade de que, por trás da acusação de "obscurecimento das intenções das intenções gerais", se esconda um ressentimento em relação a um tipo de prática artística que desafia a rígida divisão hierárquica do trabalho cultural nos EUA.

Um corte abrupto transporta o foco narrativo do estacionamento de ônibus para duas cenas paralelas. Na recepção do hospital, Del espera Barbara Jean, que acabou de receber alta, com a intenção de contratá-la para o comício de Walker no Parthenon. Enquanto isso, em um clube noturno, Triplette cuida dos preparativos para um evento de arrecadação de fundos de campanha. Os dois personagens conversam ao telefone, de modo que a conexão cria uma ponte física entre o hospital e o clube noturno, sugerindo a capacidade que o sistema que representam tem de conectar ambientes tão pouco relacionados quanto o lugar para tratamento de doenças e o clube para shows privados. Os objetivos que motivam a conexão destes espaços não são acessíveis para a consciência das duas personagens às quais estão dirigidas as ações de Triplette e Del: Barbara Jean será a atração principal do comício, mas, no clube noturno, é a principiante Sueleen quem será coagida a exibir-se para uma plateia de financiadores de campanha; a amadora não sabe que seu trabalho viabilizará a contratação da cantora famosa e esta não faz ideia das concessões que Sueleen será forçada a fazer de modo que ela possa "brilhar" no comício.

${ }^{209}$ ABRAHAMS, Steven. Buying Nashville. Jump Cut, n. 9, 1975. (versão online). 
Somente Del e Triplette, na condição de intermediários de Walker, guardam o conhecimento desta relação de produção em que a cantora profissional e a amadora foram involuntariamente postas. Os dois personagens, que mobilizam uma série de serviços de modo a fazer o comício acontecer, cumprem uma função análoga àquela desempenhada pelo fetichismo da mercadoria no funcionamento de um sistema social baseado na exploração do trabalho, a saber: o apagamento da consciência de que as relações de produção neste sistema são essencialmente desiguais. $O$ questionamento da relação de trabalho (Como pode a amadora aceitar receber apenas dez dólares para fazer uma apresentação que viabilizará um comício inteiro? Como pode a cantora consagrada aceitar que seu trabalho se alimente da exploração de um fã?) é impossível, na medida em que a consciência dessa desigualdade subjacente fica retida nas mãos dos dois "guardiães do saber".

Qualquer possibilidade de que este sistema consiga integrar de forma satisfatória todos os sujeitos é invalidada pela continuação da cena. Ao passar pela recepção, Barbara Jean encontra Mr. Green, que chegou da rua com uma vitamina e flores para sua esposa doente. A cantora deseja boa sorte a Mr. Green e saúde à enferma. A algazarra formada pela sua saída contagia todos os presentes, incluindo transeuntes e funcionários do hospital. Porém, quando todos se vão e o silêncio retorna ao ambiente, a recepcionista dá a Mr. Green, de um só golpe, a notícia de que sua esposa morreu naquela manhã. A recepcionista recolhe as flores que ele trazia, enquanto Mr. Green tenta absorver o choque, com olhar vazio e boca entreaberta.

A forma abrupta com que a notícia é dada sugere que, do lado de fora do sistema organizado de stars, intermediários e trabalhadores subempregados, há um universo de relações transcorrendo na anonimidade, um tipo de existência social mais desprotegida do que a já precária situação dos músicos na cidade. A recepcionista, que recebe as flores trazidas por Mr. Green e retribui com a notícia da morte, é um testemunho deste 
mundo pior do que o universo do trabalho explorado, um tipo de cotidiano em que os golpes são dados frontalmente, como coisa banal.

Em todo o filme, Mrs. Green é uma personagem cuja existência fica circunscrita aos "pontos cegos" do foco narrativo. Evocada apenas em alguns diálogos, ela sequer alcança o requisito básico da personagem fílmica: a presença na trilha sonora e na imagem. A sua existência fora da porção representada do universo ficcional deve ser vista como "redução estrutural" da posição periférica que os Green ocupam no aparato produtivo de Nashville, este sim o assunto prioritário da representação. Esta existência nas sombras do discurso suscita uma leitura dialética: por um lado, pode-se entender Mrs. Green como uma daquelas figuras sem importância, que o discurso se recusa a representar, delegando esta tarefa a personagens secundárias; por outro, pode-se entender Mrs. Green como aquele elemento incômodo, residual, que o discurso tenta varrer da representação, mas que continua se assomando, ainda que na fala de personagens aparentemente sem importância.

$\mathrm{Na}$ realidade cotidiana de uma cidade modernizada pela cultura country, a indústria fonográfica não organiza apenas um setor da vida econômica; ela organiza toda a vida social. Em um tipo de sociabilidade que vive da exposição, a anonimidade equivale à morte e deixar de aparecer é efetivamente morrer para relações sociais espetacularizadas. De fato, como bem observou Ryan Gilbey, o "medo da morte no cinema de Altman está inextricavelmente ligado ao medo do silêncio." ${ }^{210}$ Portanto, quando Mr. Green tenta promover o encontro entre Martha, sua sobrinha, e Mrs. Green, simbolicamente, seus esforços visam a "salvar narrativamente" a esposa, trazendo-a do universo evocado no diálogo para o campo da representação visual. Este esforço de salvamento simbólico é acompanhado pelo gesto concreto de trazer a vitamina que melhorará o estado de saúde da enferma. Porém, assim como o remédio de Mr. Green chega tarde demais, o encontro 
entre tia e sobrinha não acontecerá e a personagem fica definitivamente "perdida" para o filme.

Em um famoso ensaio, Walter Benjamin nos ensina que o instante que precede a morte é a base da autoridade do narrador, o momento em que a existência vivida do homem - a substância da narrativa assume uma forma transmissível e o moribundo pode falar com autoridade aos vivos, lançando o "gancho" da continuação da história contada por sua vida próxima do fim. Ao morrer anonimamente, sem a atenção de serviços médicos ocupados com a estrela da música e sem a presença da sobrinha a quem tinha algo a dizer, Mrs. Green dá notícia de uma sociedade em que "a morte é cada vez mais expulsa do universo dos vivos" ${ }^{211}$; no recalcamento social da consciência de que todo processo, inclusive o desdobramento de uma vida, caminha para um fim, perde-se o próprio sentido histórico de uma narrativa incompleta que não poderá ser retomada futuramente. Portanto, a imagem de Mr. Green, chorando com o frasco de vitaminas na mão, suscita uma leitura alegórica, para além do drama familiar: ele é também alguém que chora a perda de uma narrativa, solapada, junto com o universo de relações que a embasava, pela sociedade que se erguia naqueles anos 1970.

A presença de Barbara Jean no momento da notícia associa indiretamente essa morte anônima ao tema do assassinato político, pois, no Parthenon, é a cantora quem morrerá interrompendo o fio de outra narrativa, aquela contada pelo próprio filme. $\mathrm{Na}$ passagem da cantora pela recepção, Barnett, seu marido e empresário, traz à tona a palavra que liga as duas mortes, referindo-se à comitiva que segue sua esposa até o elevador como um "cortejo". Literalmente, a personagem escapa de ouvir a notícia da morte de Mrs. Green para acompanhar o próprio "enterro" até o Centennial Park, onde a narração fará de seu assassinato o ponto final de uma história do vigor de um sistema econômico destrutivo e da perda de vários dos sonhos que animaram a

${ }^{210}$ GILBEY, Ryan. It Don't Worry Me. p. 146.

${ }^{211}$ BENJAMIN, Walter. O narrador. in: Magia e Técnica, Arte e Política. p. 207. 
experiência política até os anos 1970. No que tem de espetacular, a sua morte é o avesso daquela de Mrs. Green, não apenas encontrando uma representação gráfica detalhada do instante mortal, como também sendo mapeada em todos os seus antecedentes, incluindo a internação hospitalar.

$\mathrm{Na}$ contraposição destas duas vidas e destas duas mortes, uma excessivamente anônima, a outra excessivamente pública, revelam-se contradições da sociedade do espetáculo: não existir nas representações espetaculares significa estar "morto", mas, para alcançar a representação, é necessário aceitar um tipo de práxis vital - a alienação cotidiana da energia produtiva incorporada ao espetáculo - que efetivamente transforma um "modo de vida" em um "modo de morte":

"Imobilizada no centro falsificado de seu mundo, a consciência espectadora já não conhece em sua própria vida uma passagem para sua realização e para sua morte. Quem desistiu de despender sua vida já não deve reconhecer sua morte. A publicidade dos seguros de vida apenas insinua que o indivíduo é culpado de morrer sem ter garantido a regulação do sistema depois dessa perda econômica; e a do American way of death insiste na capacidade de manter nesse encontro a maior parte das aparências da vida. Nos bombardeios publicitários restantes, é nitidamente proibido envelhecer. É como se houvesse uma tentativa de manter, em todo indivíduo, um 'capital-juventude' que, por ter sido usado de um modo medíocre, não pode pretender adquirir a realidade durável e cumulativa do capital financeiro. Essa ausência social da morte é idêntica à ausência social da vida."212

A contradição, categoria dialética por excelência, é o tipo de relação que o "olhar narrador" utiliza para ligar a imagem patética de Mr. Green recebendo a notícia da morte de sua esposa ao quadro temático seguinte: o choro de Mr. Green na recepção do hospital é justaposto ao riso de Triplette no clube noturno, em um espelhamento tão perfeito que os dois gestos antitéticos quase chegam a fundir-se. Esta inversão/fusão aproxima os dois quadros díspares, sugerindo uma relação espelhada entre os problemas apresentados no primeiro e a teoria do assassinato político a ser exposta no segundo.

${ }^{212}$ DEBORD, Guy. A Sociedade do Espetáculo. Tese 160, p. 108 - 109. 
É desta teoria que Triplette ri e quem a emite é Opal, em um de seus raros momentos de lucidez:

"Espere aí, não ria... Eu tenho uma teoria a respeito do assassinato político: veja bem, eu acho que gente como Madame Pearl e todas as pessoas, neste país, que portam armas, são os verdadeiros assassinos, pois, veja só, são eles que estimulam as outras pessoas que, talvez inocentemente, puxam o gatilho no final".

Se até aqui a narração apenas lançara elementos esparsos a serem reunidos pelo espectador em um pano de fundo históricosocial que dê coerência aos acontecimentos que fecham a narrativa, na fala de Opal, ela oferece uma teoria do assassinato político para que o espectador teste as hipóteses já formuladas. Frequentemente considerada um "defeito" da exposição narrativo-dramática, um tangenciamento da "regra" de que na obra narrativa toda teoria deve ser traduzida em ações, a explicação trazida pela personagem responde a um princípio épico fundamental: o de que processos sociais sejam exteriorizados, nas ações das personagens, mas também, quando necessário, sejam verbalizados de modo claro nas suas falas.

Esta diferença decorre das retóricas entre o texto tradicional e o texto épico: enquanto aquele busca convencer pela verossimilhança, lançando mão de "máximas" do senso comum, que "podem ser implícitas ou jogadas para o plano de fundo"213, este convence pelo argumento, devendo, por vezes, lançar mão de explicações mais extensas. A brevíssima interação entre Opal e Triplette cumpre tão-somente uma função épica: a de criar, por meio da personagem, um canal de comunicação indireto entre o ponto de vista narrativo e o espectador. Por meio deste canal, a narração expressa seu entendimento da situação social que engendra assassinos políticos e encoraja o espectador a compará-lo com sua visão pessoal do problema.

A última frase de Opal é acompanhada de um gesto, imitando alguém que puxa o gatilho de uma arma. Este gesto encontra uma rima

${ }^{213}$ CHATMAN, Seymour. Story and Discourse. p. 51. 
visual na mão direita de Kenny, que manipula um objeto enquanto fala com a mãe, na cena seguinte, situada em outro espaço: a casa de Mr. Green. A rápida conversa telefônica caracteriza a relação entre mãe e filho e esclarece alguns pontos sobre o enunciado de Kenny: o personagem vive com a mãe, de quem fugiu, vindo parar em Nashville, mas a quem ainda deve notícias. Da mãe, o que ele ouve é uma bronca, reprovando sua fuga, o fato de estar vivendo em uma "pensão" administrada por um homem, onde há mulheres que se oferecem e onde Kenny se expõe a doenças típicas do Sul ${ }^{214}$. Enquanto isso, Martha tenta seduzi-lo, caminhando, de calcinha transparente, ao seu redor. Em um determinado momento, ela pega a caixa do violino de Kenny, mas é logo repreendida, desculpando-se, em tom inocente: "Eu só queria dar uma olhada no seu violino". Sem conseguir livrar-se da mãe, o personagem corta a ligação, pressionando o gancho do telefone, fingindo, porém, um prosseguimento com o outro lado da conexão já mudo.

A rima visual que o narrador cria ao aproximar os gestos de Opal e de Kenny serve de sugestão para que o espectador efetue uma leitura combinada da teoria do assassinato político e a conversa ao telefone, entre mãe e filho. Ao fazer o gesto de quem puxa o gatilho, Opal aponta, no próximo quadro, o personagem que se tornará, mais tarde, um assassino político, servindo, portanto, de ilustração da teoria que ela acabara de expor. Ao mesmo tempo, sugere-se que a leitura psicanalítica da cena na sala de estar, carregada de referências edipianas (o filho atrelado a uma mãe dominadora, a moça jovem que se oferece como sua substituta, o instrumento musical representando o falo que ela não deve tocar, o gesto de "cortar" a ligação telefônica, encenando, no plano simbólico, o rompimento da relação

\footnotetext{
${ }^{214}$ Para auxiliar os atores na tarefa de construir personagens, Altman os encorajava a elaborar pequenas narrativas que, embora não viessem a incorporar-se ao roteiro, criavam uma base sólida para a improvisação. Eis a "história" de Kenny, tal como relatada por David Hayward, o ator por trás do personagem: "educado por uma mãe excessivamente possessiva (ela foi abandonada por seu marido), [Kenny] procura um pai. Ele acredita tê-lo encontrado na pessoa de Walker, cujas aulas de ciência política ele frequentou na universidade. Por isso, ele persegue o político em sua campanha eleitoral, mais ou menos como Glenn segue Barbara Jean de um show a outro." HENRY, Michael. Altmanscope (sur le plateau de "Nashville"). p. 19.
} 
incestuosa) seja enriquecida pela possibilidade de uma leitura política, trazida pela teoria de Opal: tanto no papel de filho lutando contra a dominação de uma mãe que determina, de longe, o rumo de seus passos, quanto na função de assassino político que realiza, involuntariamente, o desejo da sociedade armada, Kenny se envolve em ações nas quais ele deixa de ser o sujeito que age e se torna o objeto por meio do qual se expressa uma vontade imposta à sua.

A conversa entre mãe e filho pode ser vista também como um complemento à teoria do assassinato político. Se o assassino é alguém incapaz de rebelar-se contra a influência da sociedade armada, cuja vontade ele realiza, "talvez inocentemente", sua caracterização como um sujeito que não consegue libertar-se da mãe dominadora sugere que a sociedade que produz trajetórias edipianas incompletas é uma sociedade repleta de assassinos políticos potenciais. Assim enriquecida pelos elementos trazidos na segunda cena, a teoria expressa na primeira deixa de ser aquela da personagem e deve ser vista como a teoria proposta pelo próprio "narrador".

Tendo traçado um mosaico do funcionamento da cultura country em Nashville, a narração se concentra, nos últimos quadros desta seção intermediária, na construção de uma teoria do assassinato político que dará coerência argumentativa ao prosseguimento do filme. Com um estilo de composição que privilegia a contradição (entre planos, cenas, sequências, quadros), em vez da causalidade narrativa, o filme consegue mapear práticas culturais conservadoras sem, no entanto, deixar que sua própria técnica produtiva sucumba à natureza do assunto. Deste modo, o "épico possível" de Nashville vai-se definindo como uma obra monumental, capaz de produzir um diagnóstico amplo sobre os movimentos políticos, econômicos e sociais de seu tempo, ao examinar de perto o processo de rápida modernização por que passava a "cidade da música", nos anos 1970. 


\section{5: tirando a roupa}

O corte abrupto do conjunto anterior para este, que é o penúltimo quadro do filme, sugere um salto temático. O quadro é composto de três longas sequências, a primeira das quais tem seu valor individual preservado na justaposição formal da montagem; já as outras duas são fragmentadas e correm em paralelo, junto com cenas adjacentes contendo seus antecedentes e desdobramentos imediatos. O que dá unidade temática ao conjunto é o gesto de "tirar a roupa", representado, literalmente, em um número de strip-tease, recuperado, simbolicamente, nas concessões políticas que Barbara Jean é obrigada a fazer, encenado na estrutura de recepção de uma "música mercadoria", e invertido na cena em que vemos Linnea vestir-se diante do espelho. $\mathrm{Na}$ ordem em que se sucedem, as ações principais das cenas e sequências que reviram este gesto dialeticamente são: no Opry Belle, Barnett se recusa a assinar um contrato para participação de Barbara Jean no comício de Walker, mas é obrigado a fazê-lo quando a cantora tem um colapso em cena; um telefonema de Tom atrai Linnea ao Exit Inn, onde ele faz um show ao lado de Bill e Mary; Sueleen Gay canta uma música de sua autoria no clube de striptease, sem saber que é a "atração principal" da noite; Tom dedica a canção "I'm Easy" a Linnea, mas todas as mulheres presentes se sentem igualmente homenageadas; debaixo de vaias, Sueleen tenta escapar do clube de striptease, mas uma proposta de Triplette a convence a voltar ao palco e "terminar o show'; em um quarto de hotel, Linnea se recompõe diante do espelho e ouve Tom ligar para a próxima mulher que ocupará sua cama; na porta de casa, Sueleen tem uma discussão com Wade após se livrar das investidas de Del.

Ao longo destas cenas e sequências, a narração investiga o modo como se constituem e se desfazem alinhamentos no momento em que o mercado tomou conta não apenas das relações de produção, mas também enquadra, com a sua forma de base, as relações políticas e amorosas. 
Neste contexto, a capacidade demonstrada pelos agentes do mercado, coagindo a cantora famosa a trocar sua adesão política por uma oportunidade de retratarse com o público, recupera, nos termos da indústria cultural, a estratégia que funda a dominação do capital sobre o trabalho, qual seja, a expropriação dos meios necessários à sua realização para forçá-lo a vender-se como mercadoria. A mesma lógica é imposta à cantora amadora, para quem a possibilidade de integrar-se ao processo de trabalho é transformada em um objeto de troca, que estimula seu sonho de ascensão social, apenas para persuadi-la a aceitar, estoicamente, seu rebaixamento moral no strip-tease. De modo análogo, o corpo do star, desde sempre desejado como uma "mercadoria especial", desdobra-se em imagem na letra de "I'm Easy", funcionando também como arma de convencimento. Na montagem horizontal entre as sequências, um argumento vai-se desenhando: quer seja na forma de coação pelo poder do dinheiro, quer seja efetuando o recalcamento do desejo por meio de sua satisfação ilusória, as trocas libidinais e econômicas, mediadas pelo fetichismo, são equiparadas como evidências de uma política assimétrica e essencialmente autoritária.

A primeira sequência do conjunto é aquela em que vemos Barbara Jean no Opry Belle, uma arena ao ar livre, com palco em forma de convés de antigo vapor do Mississippi, montada no Opryland, o parque de diversões country da cidade. A sequência pode ser dividida em quatro movimentos: a chegada da cantora ao local do show, acompanhada das primeiras investidas do empresário de Walker, a realização de dois números musicais, o monólogo seguido de um colapso em cena e, finalmente, o fechamento do contrato de trabalho para participar do comício. Nestes quatro movimentos se atualiza o processo histórico figurado no enunciado da personagem: a negação do significado político do trabalho artístico, a exposição da produção normal, o rompimento da normalidade, a reconstituição do equilíbrio por meio de uma aliança produzida a contragosto.

$\mathrm{Na}$ sua chegada aos bastidores do show, Barbara Jean é cercada por repórteres enquanto Barnett, seu marido e empresário, é 
assediado por Triplette e Del, encarregados de organizar o comício televisionado de Walker:

Barnett: O que você quer agora? Esse cara aqui está querendo que ela faça quatro shows. E você? O que quer?

Del: (segurando firmemente os ombros de Barnett, como se cercasse sua passagem, em um gesto de "autoridade amistosa") Não deixe que ela trabalhe demais. Como é que você vai? Está se sentindo melhor? E ela? Está se sentindo melhor?

Barnett: Sim, estou ótimo.

Del: Nós temos que falar com você. Nós vamos fazer um show, OK? O John aqui é que vai fazer esse show. Haven vai participar. Nós queremos que Barbara Jean seja a atração principal.

Barnett: Mas é incrível!

Del: Não, espera um segundo, cara. É em rede nacional de televisão para um candidato chamado Hal Phillip Walker.

Triplette: Escuta, Barnett, nós não queremos que ela dê nenhum depoimento político.

Barnett: $\mathrm{E}$ o que você acha que a presença dela significa? Não seria um depoimento político? Não, meus amigos, não levem pelo lado pessoal. Nada de política, nada de governo, nada. Tudo bem? Agora eu já ouvi vocês.

Triplette: Esquece, Barnett.

Del: Não, John, deixa comigo. Eu vou ficar na cola desse cara igual a um roedor.

O diálogo rápido estabelece a posição de neutralidade que Barnett e Barbara Jean se esforçam por manter e ecoa outras tentativas de 
resistir às investidas de Walker ao longo do filme: o comentário de Tom, no aeroporto ("Eu não voto em ninguém para presidente"); a ressalva feita por Pearl à participação de Haven em campanhas ("Mas nós nunca deixamos Haven Hamilton se posicionar politicamente"); a objeção de Mary ao candidato ("Eu sou uma afiliada ao Partido Democrata; eu não poderia votar nele"). Porém, é na voz de Barnett que o esforço de alienar-se do jogo político tem o sentido mais claro de uma estratégia empresarial, um princípio que rege as ações tomadas na gestão dos negócios de Barbara Jean: consciente de que a mera participação da cantora no comício seria vista como um endosso a um candidato percebido como radical, o que poderia ser mal recebido pelas porções de seu público refratárias a Walker, o empresário abre mão da publicidade televisiva para preservar uma fatia de mercado consolidada.

Assim como nas outras resistências espalhadas no filme, a estratégia empresarial de Barnett pressupõe a possibilidade de separar política de produção cultural. Porém, como nos ensina Michael Denning, no caso específico dos EUA, esta separação nunca foi respaldada pela realidade, pois a ascensão das indústrias culturais norte-americanas é incompreensível sem a ação conjunta do capital, encabeçando o desenvolvimento de novas tecnologias de comunicação e difusão, do enorme contingente de trabalhadores desempregados que transformaram o cinema, o rádio e a música em um campo de luta política por direitos, sobretudo pelo direito ao trabalho, e, finalmente, das políticas públicas de fomento e difusão da cultura durante o período da Grande Depressão. ${ }^{215}$ Desde modo, para Barnett e sua esposa, a sequência tem o valor de um "choque de realidade", passando da exposição meio ingênua e meio cínica de um distanciamento em relação à política para a descoberta de que é impossível não tomar partido no momento em que a dominação do capital se torna uma força determinante até mesmo das escolhas supostamente individuais.

${ }^{215}$ DENNING, Michael. The Cultural Apparatus. in: The Cultural Front. p. $38-50$. 
Após ser aclamada na sua chegada ao "convés" do Opry Belle, Barbara Jean desce uma rampa, alcançando um segundo palco, em forma de píer, de onde se lança em uma performance animada de "Tape-deck in his Tractor", dando provas de desenvoltura no espaço cênico e de aparente recuperação da saúde.

Plano de conjunto, tomado por trás da cantora, sobrepondo sua imagem à da plateia, transformada em pano de fundo do quadro. Barbara Jean começa a cantar:

"O seu trator tem um rádio toca-fitas onde ele ouve as notícias locais."

Contracampo: plano frontal da cantora com os músicos atrás.

"Ele descobre onde os peixes mordem a isca enquanto ara a terra ao som de um country blues.

Ele era cowboy e sabia que eu o amava muito.

Segredos de cowboy não se contam."

Contracampo: tomada de conjunto da plateia. Da esquerda para a direita, entra Opal, a jornalista, caminhando na extensão lateral da tela até encontrar assento na escadaria, ao lado do soldado Kelly, que assiste absorto ao show de seu ídolo. A câmera acompanha o movimento horizontal da personagem até revelar a cantora no palco.

"Não há nada como o amor de um cowboy trabalhador."

"O seu trator tem um rádio toca-fitas e ele vai arando as terras de seu pai."

"Ele tem mais experiência de vida do que eu já vi em qualquer outro homem." 
Plano próximo do baterista em sincronia com 0 destaque de seu instrumento na trilha sonora, seguido de uma tomada frontal da cantora com todos os músicos ao fundo.

"Ele era cowboy e sabia (...)."

Tomada mais próxima da plateia, onde agora se podem discernir os rostos de duas adolescentes com expressão aborrecida e duas mulheres tirando fotos, seguida da demonstração do virtuosismo da cantora no contracampo.

"Aos sábados à noite, nós vamos à cidade.

E a rapaziada sempre pede outra rodada."

Plano médio da porção mais adulta da plateia, revelando alguns rostos com ar de curiosidade comportada e vários idosos com semblante cansado, seguido, no contracampo, de uma tomada aberta fechandose progressivamente em close-up da expressão radiante de Barbara Jean.

“No verão, ansiosamente esperamos pelo rodeio.

Aos sábados à noite, nós vamos à cidade.

E a rapaziada sempre pede outra rodada.

Quando ele monta um cavalo bravo no rodeio, eu espero para ouvir aquele apito tocar.

O seu trator tem um rádio toca-fitas que eu escuto quando ele volta pra casa.

Então ele me abraça na cadeira de balanço e canta uma canção de amor.

Ele era cowboy e sabia (...).,216

\footnotetext{
216 "He's got a tape-deck in his tractor and he listens to the local news./ He finds out where the bass are biting while he's plowing to the country blues./ He was a cowboy and he knew I loved
} 
O foco narrativo alterna imagens no campo e no contracampo, mas toca a canção de Barbara Jean inteira, sem interrupções, transformando-a em um elemento de coesão no nível da trilha sonora. Ou seja, a performance de "Tape-deck in his Tractor" funciona como elo de ligação de uma montagem "espelhada" entre palco e plateia: vemos a cantora, a reação do público, os músicos, a reação do público, etc., sugerindo que a narração se interessa tanto pela análise dos processos que ocorrem no palco quanto pela figuração de sua recepção. A plateia é representada como uma massa comprimida pelo enquadramento; captada em bloco, ou em recortes cuja proximidade não excede o mínimo necessário para se discernir a expressão de um rosto, ela emerge como um tableau de fisionomias cansadas e apáticas a ser contrastado à imagem de jovialidade e alegria da cantora. Não se trata de uma plateia totalmente encenada; assim como em outros momentos do filme, o público do Opry Belle é composto por moradores da cidade que Altman conseguiu atrair para as locações, o que o transforma em um objeto de curiosidade tão atraente quanto a personagem no palco.

Até esse ponto da cena, esse público se comporta de forma ordeira, respondendo, sem muito entusiasmo, mas tampouco sem indisciplina, à canção que vai de encontro às suas expectativas. Trata-se, como sugere um comentário de Barnett ("Falei para a banda que você vai começar com aquela música do cowboy"), de um número rotineiro da cantora. A sua letra sugere uma espécie de "idílio moderno", resultado da combinação de signos da vida simples no campo (a cadeira de balanço, a pescaria, a montaria, os divertimentos inocentes, o trabalho na terra dos pais) com um elogio aos produtos do avanço técnico, tais como o trator e o rádio toca-fitas. Com isso, a

him well./ A cowboy's secrets, you never tell./ Now there's nothing like the loving of a hard-driving cowboy man./ He's got a tape-deck in his tractor while he's plowing up his daddy's land./ He's got more horse-sense than I ever seen in any man./ He was a cowboy and he knew (...)./ On Saturday nights, we go dancing in town./ And all the boys will order up another round./ In the summertime, we look forward to the rodeo./ On Saturday nights, we go dancing in town./ And all the boys will order up another round./ When he rides saddle bronc I wait to hear that whistle blow./ He's got a tape-deck in his tractor I can hear him when he's coming home./ Then he holds me in the rocking chair and sings me the love song./ He was a cowboy and he knew (...)." 
letra da canção resvala em um impasse formal da estrutura poética country, que consiste na tentativa de encaixar o conteúdo reacionário da poesia pastoril (o desejo de retorno a antigas formas de dominação) no "imaginário tecnológico" da cultura de massas ${ }^{217}$.

Esse impasse é reproduzido na figura que atrai a atenção do "eu-lírico": o cowboy. Diferente do pastor de ovelhas, cujo caminhar em harmonia com a natureza indomada inspirava uma aceitação das relações de dominação como um prosseguimento das leis naturais, a figura solitária e antissocial do cowboy não se presta a figurar, diretamente, a manutenção da ordem. Portanto, o seu aproveitamento na linguagem pastoril de "Tape-deck in his Tractor" requer distorções, tais como a sua "heroicização" nos primeiros westerns de John Ford ou sua representação erotizada na publicidade de uma famosa marca de cigarros. O cowboy de Barbara Jean bebe nessas fontes, mas baixa o tom do tratamento em algumas notas. Não tão valoroso como os primeiros personagens de John Wayne, ele, no entanto, é alguém que demonstra sabedoria nos assuntos do campo, que vive nas terras dos pais e que, principalmente, encara o trabalho duro com alegria. Mesmo não exalando a sensualidade arrebatadora do Marlboro Man, ele alcança resultados parecidos por meio de pequenos gestos, como um abraço na cadeira de balanço ou uma canção de amor. A música, aliás, é o elemento que dá unidade à sua experiência: companheira das horas de trabalho, som para dançar nos momentos de lazer, poesia dirigida à amada na segurança do lar, ela cria uma estrutura de sentido para a adaptação do cowboy, que trocou a vida "perigosamente livre" nas planícies pela rotina de divertimentos "sadios" e a certeza do trabalho diário. A síntese desta imagem "idílica" do desejo

${ }^{217}$ Robert Kurz, em um artigo publicado na Folha de São Paulo, lembra que este tipo de idealização do passado, cuja origem está na filosofia do iluminismo, é tão reacionário quanto a violência da modernidade contra a História, figurada na moda, no progresso ininterrupto, nas ideologias do fim da História, etc. Neste tipo de idealização, "não se apreende o valor próprio das culturas passadas nem o aspecto destrutivo da dinâmica capitalista; antes é sempre mistificada, projetada no passado, a relação capitalista." KURZ, Robert. O tédio mortal da modernidade. Folha de São Paulo, 28.11.1999, Caderno Mais!, p. 3. 
domesticado pelo trabalho é repetida no estribilho, na forma de uma avaliação: "Não há nada como o amor de um cowboy trabalhador."

Para uma plateia que o "olhar da câmera" surpreende em uma expressão cansada, a visão da cantora jovem e aparentemente cheia de energia, cantando, em idílio, uma vida de trabalho duro e gozo limitado, deve ter o valor de uma imagem consoladora. Entretanto, a recepção apática durante todo o número pode ser o indício de que, embora induza à resignação, o fetiche já não consegue mascarar a miséria da via cotidiana de modo que a canção já não contagia. Essa "dificuldade de empolgar" não pode ser atribuída à execução de Barbara Jean e dos músicos, impecável, se levarmos em conta os critérios estéticos country, nem à música rápida, de melodia fácil, bem de acordo com o gosto do público; ela só pode advir da percepção de contradições na poesia da canção.

Composta por Ronee Blakley, a atriz por trás de Barbara Jean, "Tape-deck in his Tractor" é mais um enriquecimento da cena viabilizado pela estrutura colaborativa do set de Altman. Diferente de outros atores/compositores no filme, Blakley tinha sólida formação musical, o que deu às canções de sua autoria (ela também recebeu os créditos por "Dues", "Bluebird", "One I Love You" e "My Idaho Home"), e às suas performances diante do microfone, um nível de desempenho técnico muito próximo daquele exigido pelos padrões country. Entretanto, isso não impediu que a atriz transferisse livremente alguns traços de sua própria vivência do trabalho musical para as contribuições que trouxe ao filme, criando contradições reveladoras no nível das imagens poéticas.

Blakley cresceu em uma família tradicional do interior de Idaho;

"Seus pais lhe incutiram uma firme ética do trabalho. Todos os dias, Blakley acordava às seis para estudar piano por duas horas, antes do café da manhã. 'Na condição de primogênita', ela escreveu em um currículo poético de 1972, 'eu fui educada para 
caçar, pescar e andar como um índio bravo sobre os campos de beterraba de manhã. Mas também estudei balé, piano e costura." ${ }^{218}$

É impossível não reconhecer os traços deixados por esta "ética do trabalho" no estribilho de "Tape-deck in his Tractor"; tampouco se pode deixar de notar uma contradição entre a alegria com que a personagem canta a resignação do cowboy à sua rotina e certa amargura da atriz ao lembrar que as atividades prazerosas que marcaram sua infância no campo foram, desde cedo, dosadas por outras que lhe prepararam para o trabalho. É possível que a reação apática da plateia genuína se deva a um pressentimento de que esse tipo de compromisso exigido pelo trabalho é, antes uma renúncia pura e simples, do que um adiamento do prazer e que, por trás da representação idílica, se esconde o reconhecimento amargo de que a modernização rebaixou a experiência do cowboy ao nível da miséria cotidiana do proletariado urbano.

Assim como seus ancestrais da planície, o cowboy na canção não está atrelado à terra, mas, no seu caso, isso não é sinal de liberdade e sim de despossessão; ele trabalha para os pais porque não tem terra: "O seu trator tem um rádio toca-fitas e ele vai arando as terras de seu pai." Atrás do volante do trator, o seu percurso no espaço já não descreve um tempo subjetivo, mas cumpre a trajetória definida pelos campos a serem arados. Em outras palavras, ele agora é prisioneiro da mesma temporalidade cíclica que caracteriza a rotina industrial: a jornada de cinco dias, os divertimentos de sábado à noite, o anseio pela chegada das férias no verão: "No verão, ansiosamente esperamos pelo rodeio./ Aos sábados à noite, nós vamos à cidade". Destronado de seu posto de "cavaleiro itinerante", ele já não tem nada a contar ou a cantar, tornando-se um consumidor das notícias que recebe no seu rádio toca-fitas e dos rodeios periódicos que renovam a possibilidade de contemplar, na forma de espetáculo, sua antiga atividade de domar cavalos. Essas atividades de consumo dão uniformidade à sua vivência cotidiana e educam os seus gestos: a música enlatada marca o ritmo da lida diária e da

${ }^{218}$ STUART, Jan. The Nashville Chronicles. p. 83. 
dança nas noites de sábado, servindo também de tempero para a vida amorosa insossa na volta à casa. Em troca de tanta modernidade, ele renunciou à expressão viva do desejo, conformando-o ao ritual cotidiano do abraço na cadeira de balanço: "O seu trator tem um rádio toca-fitas que eu escuto quando ele volta pra casa/ Então ele me abraça na cadeira de balanço e canta uma canção de amor". Em outras palavras, assim como a música enlatada efetuou uma incorporação espúria de imagens pastoris, "requentando", com as modernas tecnologias de registro e difusão do som, os elementos conservadores da forma poética arcaica e superada, a modernização capitalista enquadrou as atividades no campo dentro da temporalidade da produção industrial, solapando as condições históricas da comunidade rural imaginada, mas conservando seus elementos de atraso: o provincianismo dos hábitos, os horizontes restritos, a renúncia ao prazer. Em um determinado verso, a canção diz que o cowboy "ara a terra ao som de um country blues"; talvez a plateia pressinta que o conteúdo deste blues não é outro senão a miséria do "operário do campo" expropriado de sua energia vital. ${ }^{219}$

"Dues", o número seguinte de Barbara Jean, é apresentado pela narração em mais um jogo de campo e contracampo. Porém, o espelhamento pretendido agora não é mais entre plateia e palco, mas entre os sentimentos expressos pela cantora e aqueles de dois de seus espectadores: Kenny e o soldado Kelly. Esta segunda canção também foi composta por Ronee Blakley e aproveitada como um recurso épico na cena: além de dar coesão sonora à montagem que alterna pontos de observação, alguns de seus versos foram usados para criar pequenos comentários sobre os espectadores enfocados.

${ }^{219}$ O blues é uma forma musical de base africana, criada a partir dos spirituals (cantos religiosos) e das "canções de trabalho" dos negros libertos. Muitas vezes tratando da escravidão, o blues tem uma expressividade triste, condizente com o significado em inglês do termo "the blues": tristeza profunda, depressão. 
Plano médio de dois violinistas e um tocador de pedal steel guitar. Introdução dos primeiros acordes de "Dues", cortando, no eixo da tomada, para um plano aberto da cantora.

"É este desrespeito sem cuidado que eu não aguento mais, baby.

É o modo como você não me ama, quando diz me amar, baby.

Dói tanto e me joga pra baixo, pra baixo, pra baixo."

Contracampo: em um plano médio da plateia, vemos Kenny chegar, no lado esquerdo, e caminhar toda a extensão horizontal da tela, indo sentar-se atrás de uma lata de lixo.

Eu só quero é fugir desse campo de batalhas.

Esse joguinho de machucar não é nada bom."

Contracampo: imagem frontal da cantora, em plano médio, seguida de plano próximo dos violinistas.

"Eu daria tudo para te amar do modo como eu te amava antes.

Se pelo menos eu pudesse!"

Contracampo: plano americano de Kenny, Opal e Kelly, progredindo suavemente para um close-up do rosto do primeiro.

"Bom, você vive no seu próprio mundo privado.

Eu não o conceberia de outra forma.

Mas ultimamente você tem escondido a sua tristeza.

Dizendo coisas que não sente."

Contracampo: rosto da cantora, em close-up, tomado de súbita emoção, cortando para uma tomada invertida, com três camadas de 
imagem. No primeiríssimo plano, a nuca de um violinista faz o enquadramento; no plano intermediário, a cabeça de Barbara Jean se dilui na variação de cores das roupas usadas pela plateia, compondo o fundo.

"Dói tanto e me joga pra baixo, pra baixo, pra baixo.

Eu só quero é fugir desse campo de batalhas.

Esse joguinho de machucar não é nada bom (...).”

Plano americano do soldado Kelly e de Opal:

Opal: Você esteve no Vietnã?

Kelly: (despertando de seu transe) Ahn? (balança a cabeça em gesto afirmativo)

"Escrever o que sinto me faz sentir melhor."

Opal: Sim, esteve. Dá pra ver na sua cara.

Contracampo: close-up do rosto de Barbara Jean.

"Não deixa eu me sentir deprimida.

Eu quero ser boa pra você, te tratar bem,

mas até quando eu vou ter de pagar esta conta?

Dói tanto e me joga pra baixo, pra baixo, pra baixo.

Eu só quero é fugir desse campo de batalhas.

Esse joguinho de machucar não é nada bom (...).,220

\footnotetext{
220 "It's that careless disrespect I can't take no more, baby./ It's the way that you don't love me, when you say you do, baby./ It hurts so bad, it gets me down, down, down./ I want to get away from this battleground./ This hurting match, it ain't no goo./ l'd give a lot to love you the way I used to do./ Wish I could./ Well, you got your own private world./ I wouldn't have it no other way./ But lately you've been hiding your blues,/ pretending what you say./ It hurts so bad (...)./ Wish I could./ Writing it down kind of makes me feel better./ It keeps me away from them blues./ I want to be nice to you, treat you right./ But how long can I pay these dues?/ It hurts so bad (...)./ Wish I could."
} 
Contracampo: plano americano de Kelly e Opal.

Opal: Foi terrível?

Kelly: (balançando a cabeça negativamente) Foi meio quente e úmido.

Close-up do rosto de Kenny. Com expressão pensativa, o personagem olha para o lado de onde vieram as últimas frases de Kelly e Opal e, em seguida, para frente, onde está a cantora, como se conectasse espectadores e espetáculo, por meio do pensamento. Corte para um plano americano dos empresários e da imprensa no fundo do palco, seguindo para um plano médio da cantora fazendo as últimas vocalizações da canção. Um plano invertido retoma aquele que iniciara o primeiro número musical: Barbara Jean de costas, sobreposta à imagem da plateia compondo um pano de fundo. Aplausos. Agradecimentos.

A forma ostensiva da canção, que fala de arrependimentos e recriminações, pede uma leitura na chave da "briga conjugal", encorajada ainda pela relação tumultuosa de Barbara Jean e Barnett, tal como ficou registrada na cena do desentendimento no hospital. Entretanto, essa interpretação mais superficial é desautorizada pela narração, que "pinça" alguns versos para esclarecer o enunciado dos personagens na plateia. Em um desses comentários épicos, o verso "Dói muito e me joga pra baixo, pra baixo, pra baixo" coincide com a entrada de Kenny em cena e seu posicionamento atrás de uma lata de lixo, marcando, na trilha sonora e na imagem, o desvalimento social do personagem. Adiante, quando Barbara Jean canta "Você vive no seu próprio mundo privado./ Eu não o conceberia de outra forma./ Mas ultimamente você tem escondido a sua tristeza./ Dizendo coisas que não sente", o rosto pensativo de Kenny aparece aumentado em close-up, salientando a intervenção de uma instância narradora que produz, no plano do discurso, um encontro iluminador entre som e imagem. 
Robert T. Self entende que essas intervenções têm uma função tanto geral, contribuindo para o tecido da narrativa autoconsciente de Nashville, quanto localizada, trazendo uma nova explicação para o assassinato a ser cometido por Kenny no Centennial Park:

"A música e o ambiente oferecem estímulos suficientes a Kenny [...]. Albuquerque, a primeira pessoa que ele encontra, está fugindo do marido, Star (Bert Remsen), que diz a Kenny que ele se parece com um daqueles rapazes sujos que tentam escapar do alistamento. É ele quem recebe o soco que Wade dirigira a Tommy Brown no Picking Parlor. A câmera o isola no mesmo quadro em que o furgão de Hal Phillip Walker proclama: 'se é para fazer uma limpeza, somos nós mesmos que teremos de fazê-la'. Conforme Connie White (Karen Black) canta uma letra que exprime escuridão interior, a câmera baixa fecha em um close-up angulado do rosto de Kenny. Depois de uma conversa telefônica tensa e impaciente com sua mãe superprotetora e inoportuna (a quem ele diz 'eu te amo' apenas depois de cortar a conexão), a câmera o observa novamente em um close-up extremamente angulado conforme ele ouve Barbara Jean cantar [no Opry Belle]. [...]. Quando o filme se aproxima de seu clímax, Kenny persegue um histérico Mr. Green, que foge do funeral de sua esposa para exigir respeito aos mortos no comício, onde Kenny atira em Barbara Jean. Engano, violência e, finalmente, a morte, dão forma à relação entre Kenny, como um outsider, e o mundo de Nashville."221

Embora a interpretação de Robert T. Self se esforce em reconstruir, a partir de uma série de "motivações" identificada ao longo do filme, uma lógica narrativa excessivamente rígida para a explicação do assassinato de Barbara Jean, ela tem a vantagem de desautorizar a crítica desatenta aos acontecimentos representados no Centennial Park, entendidos como uma "falsa solução" sem nenhuma causa reconhecível na história. Como sugere o resumo de T. Self, é só para um olhar distraído que o ato de Kenny aparece como uma surpresa inexplicável. Contudo, não se pode tomar a sequência de humilhações sofridas pelo personagem como o tronco de um enredo apontando para um clímax e podar, no processo, todas as demais ramificações da história, pois violência, humilhação e exclusão são sofrimentos estendidos a um espectro muito mais amplo de personagens. Além disso, seguindo a própria lógica do assassinato político expressa no quadro anterior,

${ }^{221}$ SELF, Robert T. Robert Altman's Subliminal Reality. p. 194. 
aquele que puxa o gatilho é apenas um meio de expressão para a raiva coletiva escolhido no calor da hora. Portanto, quando o rosto de Kenny é "pinçado" atrás de uma lata de lixo, no meio da plateia apática e cansada, e explicado com os versos que falam de sua tristeza, o enunciado narrativo não parece dizer algo como "este sujeito cometerá um assassinato", mas sim que "as frustrações contidas por essa massa de despossuídos podem encontrar um escape repentino em qualquer um de seus componentes".

O outro personagem enfocado no meio da plateia é - soldado Kelly. Veterano da guerra do Vietnã, ele surpreende pela disponibilidade que tem para perseguir Barbara Jean aonde quer que ela vá. Carregando invariavelmente uma bolsa de viagem, ele repete o gesto de Kenny trazendo sempre a caixa de seu violino, na qual, descobriremos mais tarde, se esconde a arma com que Barbara Jean será assassinada. Essa homogeneidade gestual dos dois personagens estabelece uma equivalência de seus enunciados para a progressão da história: ambos são fascinados pela cantora e carregam o mesmo potencial de tornar-se, numa reviravolta, o seu assassino. Especificamente nesta cena, a ênfase da narração recai sobre o esquecimento e a dificuldade de concentração que a experiência da guerra deixou no personagem. George C. Herring nos lembra que este custo subjetivo foi compartilhado por diversos outros veteranos:

"No período subsequente à guerra, a nação experimentou uma espécie de amnésia coletiva. [...]. Aqueles 2,7 milhões de homens e mulheres que serviram no Vietnã foram as principais vítimas do desejo nacional de esquecer. Com uma média de idade sete anos menor do que a de seus antecessores da Segunda Guerra Mundial no momento de ser enviados ao campo de batalhas, onde aguentaram as pressões de uma guerra muito mais complexa e confusa, os veteranos do Vietnã, contando com os milagres da era do jato, eram transportados de casa para uma nação hostil à sua situação, praticamente de um dia para o outro. Alguns foram culpados pelas transgressões morais da nação; outros, responsabilizados pelo seu fracasso. A maioria foi simplesmente recebida com silêncio. Forçados a se fecharem internamente, muitos veteranos se tornaram profundamente desconfiados do governo que os havia mandado para a guerra e ressentidos diante da ingratidão nacional por seus sacrifícios. A grande maioria se readaptou, embora sempre com dificuldades, mas muitos passaram por 
problemas com drogas e álcool, desemprego e lares desfeitos. Muitos foram vítimas de transtorno do estresse pós-traumático, o nome moderno para aquilo a que antes se chamava de fadiga de combate."222

Embora a amnésia que se seguiu à guerra fosse, como lembra Herring, uma enfermidade nacional, a narração deixa claro, por meio da montagem entre a canção de Barbara Jean e o diálogo entre Opal e Kelly, que os jovens veteranos arcaram com a parte mais dolorida da experiência traumática. $O$ peso da culpa que a sociedade não foi capaz de sustentar, lançando-o sobre os soldados, ecoa no verso que diz "mas até quando eu vou ter de pagar esta conta?" Se o soldado emudecido só consegue exprimir os horrores da guerra por meio de um par de imagens táteis ("Foi meio quente e úmido"), os versos da canção falam por ele: "Dói tanto e me joga pra baixo./ Eu quero fugir deste campo de batalhas." A combinação entre a formulação lacônica do personagem e a música que fascina e acalma é uma dessas imagens dialéticas que a narração vai construindo ao longo do filme: o olhar fixo do soldado na direção do horizonte, um sintoma clássico de fadiga de combate que Opal não deixa de reconhecer ("Sim, esteve [na guerra]. Dá pra ver no seu rosto"), é também o olhar do espectador absorto na performance da cantora famosa, entorpecido pelo efeito "narcótico" de sua música. Assim como "Tape-deck in his Tractor" "encorajava" a plateia cansada a resignar-se à miséria de sua vida cotidiana, "Dues" auxilia o veterano na tarefa de transformar o trauma do Vietnã em inofensiva memória sensorial, preparando, ao mesmo tempo, a sua remoção da consciência coletiva. Quanto ao ponto de vista de quem assiste ao filme, o efeito é inverso e a narração tem o sentido preciso de "contar para não esquecer", encorajando o espectador, por meio do exemplo de Kenny na cena, a estabelecer uma ligação intelectual entre o tema do diálogo e a letra da canção, conservando, na memória, a complementaridade funcional entre o militarismo dos EUA e suas indústrias culturais.

${ }^{222}$ HERRING, George C. America's Longest War. p. $305-306$. 
Portanto, até este ponto da cena, o foco narrativo se dirige, primordialmente, sobre a plateia, mapeando, nos semblantes anônimos e nas personagens misturadas a ela, os custos humanos de uma sociedade repressora, violenta e desmemoriada. O próximo passo será demonstrar que a cantora e seus músicos, o espelho desta plateia, não refletem apenas os seus ideais, mas também a realidade de seus sofrimentos e frustrações.

Plano aberto de Barbara Jean, com seus músicos ao fundo, introduzindo o próximo número. Porém, ela agora resolveu falar:

"Sabem, eu queria contar para vocês um segredinho, que talvez vocês não saibam, que é o seguinte: ontem eu agradeci minha estrela da sorte por conseguir estar aqui hoje e cantar para vocês e ouvi no rádio um menininho muito fofo de nove anos..."

Plano médio de dois guitarristas e um baterista interrompendo o número e esvaziando a trilha sonora para o discurso de Barbara Jean. Corte no eixo da imagem: cantora no primeiro plano e músicos no fundo, entreolhando-se.

“...e vocês sabem como às vezes o locutor toca uma música e pede para os ouvintes telefonarem e dizer se gostaram ou não. E então eu estava ouvindo e um menininho de nove anos telefonou e a canção tinha vozes no fundo, como esses backing vocals que às vezes se usam hoje em dia, fazendo soar como pequenos Munchkins [personagens de $O$ Mágico de $\mathrm{Oz}$ ]. Ele telefonou e o locutor perguntou: - quantos anos você tem, filho? E o menino disse: - (a cantora imita uma voz infantil) eu tenho nove e eu acho que essa música vai ser um sucesso. E o locutor perguntou por que e o menino respondeu: - (a cantora imita uma voz infantil) porque ela tem estes chipmunks [tâmia, espécie de esquilo]. (risos) $\mathrm{E}$ eu achei tão fofo porque, bem, eu sei cantar como um Munchkin. Eu não sei quanto a vocês, mas eu sou fã do Mágico de Oz e, além disso, (progressivamente nervosa e irrequieta) eu moro, vocês sabem, perto da Interestadual 24, próximo do caminho para Chattanooga. Então dá para entender por que eu fiz essa relação, eu não... (recobrando o autocontrole) Eu acho que eu e os rapazes aqui vamos cantar outra canção para vocês agora. Vamos lá meninos."

A cantora faz um aceno com a cabeça e os músicos reiniciam a introdução do próximo número. Mas, olhando para o céu com uma expressão apreensiva, ela volta a falar. 
"Eu acho que vai chover."

Contracampo: plano próximo da plateia. Alguns sorriem, outros olham sem entender o que está acontecendo. Corte para a imagem da cantora no primeiro plano e músicos no fundo, interrompendo o número mais uma vez. Silêncio; na trilha sonora apenas a voz de Barbara Jean.

"Parece que está destilando. Era assim que meu avô costuma falar antes de perder a audição. Desde que...ele ficou...surdo (voz quebrada; pausas longas), ele nunca mais falou muito, a não ser, às vezes, quando ele dizia 'ai meu deus!', 'droga!' ou 'é mesmo?"”

Corte no eixo da imagem: plano médio dos músicos. O guitarrista coça a cabeça e anda de um lado para outro em claro sinal de impaciência. Corte para um plano médio de Barnett com expressão preocupada e inquieta e, em seguida, uma tomada invertida, com a plateia no fundo e a cantora, de costas, no plano intermediário.

"Já vovó costumava andar pela casa estalando os dentes para acompanhar o rádio. Nossa! Como ela era divertida! E ainda cozinhava meu rosbife favorito. Ela era uma doçura. Ela também criava galinhas. Ela... ahn... Vocês já ouviram como faz uma galinha? Vocês já ouviram uma galinha fazer assim (imita o cacarejo de uma galinha)?"

Contracampo: plano médio de Barbara Jean. No fundo, o guitarrista impaciente começa a rir. Corte para a expressão crescentemente preocupada de Barnett.

"Deixa pra lá. Eu acho que é melhor a gente cantar essa música antes que seja tarde. Tudo bem, meninos"

A cantora marca o compasso com o dedo e balança o corpo conforme os músicos recomeçam o número. Logo, porém, ela abaixa a cabeça e recomeça a falar. Nova interrupção da música. No contracampo, um plano médio da plateia revela um quadro de fisionomias: algumas indiferentes, outras atentas, outras preocupadas. Na volta para o plano frontal da cantora, é possível ver os músicos cochichando no fundo. 
"Eu estou aqui pensando, sabem, no primeiro emprego que eu tive que foi quando a minha mãe... a minha avó... Ela é aquela que estalava a dentadura ao som do rádio o dia todo. Ela ensinou mamãe a cantar e mamãe a mim. Uma vez ela me levou, porque nós iríamos comprar uma geladeira nova, ela me levou à loja de geladeiras onde o homem estava fazendo um comercial e um disquinho promocional estava rodando e rodando e mamãe disse a ele que eu sabia cantar."

Plano médio de Barnett petrificado, avaliando o que está ocorrendo com Barbara Jean. Corte para uma tomada de conjunto, com a cantora no centro da imagem, à frente, os músicos à esquerda, Barnett e Triplette à direita, no fundo. Em seguida, um plano próximo de Barnett pedindo ajuda aos bailarinos no fundo do palco, enquanto a câmera, em um movimento no eixo, acompanha sua caminhada até Barbara Jean. No último plano, um movimento panorâmico segue a cantora enquanto ela tenta se afastar de Barnett e impedir que ele agarre o microfone de suas mãos.

"E aí, ele disse: - se ela aprender essa música, eu lhe dou vinte e cinco centavos. E aí, mamãe e eu fomos para casa (pausa longa). E então... o que foi mesmo que aconteceu? Deixe-me ver, eu acho que, ahn, sim, nós... fomos... para casa e eu aprendi os dois lados do disco em meia hora. E aí, nós voltamos lá e dissemos a ele que eu tinha aprendido as músicas e ele disse: - bom, deixe-me ouvir. E então eu cantei os dois lados do disco em vez de um só. Então ele me deu cinquenta centavos e nós atravessamos a rua e compramos um refrigerante (risos). E desde então eu tenho trabalhado, eu não... (passa a mão na testa). Eu acho que desde então eu tenho trabalhado e feito a minha... sustentado a mim mesma. De qualquer modo..."

Barnett: (rindo nervosamente) Ei, ei, ei!

Barbara Jean: (falando ao microfone) Eu estou bem? Eu estou bem?

Barnett: você está ótima, meu amor. É o microfone... me dá o microfone!

Barbara Jean: Eu ainda não acabei. Ainda não acabei.

Barnett: (segurando a cintura de Barbara Jean com uma mão, tentando agarrar o microfone com a outra, beija a face da 
cantora) Eu sei, eu sei. Agora nós vamos beber um copo d'água (recupera o microfone). Meninos, me ajudem aqui. Você vai voltar, tudo bem, querida?

Barbara Jean: (acenando para a plateia) Obrigada.

Nesta terceira parte da sequência, o foco narrativo privilegia, numa série de planos frontais do palco, a relação da cantora com os músicos que a acompanham. No contraste entre o tempo de uma estrutura psíquica que se esboroa em monólogo inacabável e aquele do trabalho pago por hora, impaciente por cumprir logo o compromisso contratado, a "subordinação de todos os outros valores ao comercialismo é figurada como um processo brutalizador, inclusive do ponto de vista pessoal", pois, ao brindar a plateia pagante com "um relatório confuso sobre o dia em que ela e sua mãe ganharam cinquenta centavos de um vendedor de geladeiras por ter aprendido a cantar não um, mas dois de seus jingles promocionais", a personagem confirma "que seu canto sempre foi uma mercadoria e uma forma de ganhar a vida." ${ }^{223}$ A possibilidade de produzir música como uma mercadoria que se vende por hora transforma a relação estética colaborativa de canto e instrumentos em uma transação comercial antagônica entre contratante e contratados, produzindo indiferença em relação a um esgotamento físico e psíquico pelo qual os músicos, em um outro modo de trabalhar, talvez sentissem empatia.

Indiretamente, ao lembrar que foram a avó, ouvinte de rádio, e a mãe que the ensinaram a cantar, Barbara Jean reconhece esta transformação de seu trabalho como uma perda. Ao recuperar, por meio da memória, a origem familiar de seu canto, a personagem refaz, no sentido inverso até sua origem, a trajetória que todo artista empregado por uma indústria cultural tem de realizar, voluntária ou involuntariamente, qual seja, o desmanche e a transferência de saberes tradicionais, aprendidos em casa ou no pequeno grupo social, para um aparato de produção e distribuição que os transforma em artigos de consumo de massa. Neste sentido, o monólogo delirante de Barbara Jean

${ }^{223}$ PECKNOLD, Diane. The Selling Sound. p. 232. 
recupera, como um lamento por uma privação, a "expropriação" que funda e conserva as indústrias culturais ${ }^{224}$.

Olhemos mais de perto a forma deste monólogo. Iniciado como um simples relato, aparentemente ensaiado, a respeito de uma história ouvida no rádio, ele vai-se desdobrando em associações de imagens, reminiscências e comentários, alguns mais, outros menos, disparatados: a história da troca de palavras pelo menino no programa de rádio, O Mágico de $\mathrm{O} z$, a residência próxima à estrada interestadual, a tempestade que se anuncia, o avô, sua surdez, as frases que o avô dizia, várias pausas por conta da emoção causada pela reminiscência, a avó, seu hábito de estalar os dentes ouvindo rádio, a comida que a avó fazia, as galinhas que a avó criava, o cacarejo das galinhas, o primeiro emprego, a avó e outra vez o hábito de estalar os dentes, o aprendizado do canto, a ida com a mãe (ou com a avó? o relato mistura as duas) à loja de geladeiras, o encontro com o promotor de geladeiras, o acordo para aprender o jingle comercial, uma longa pausa para ordenar as ideias, a volta à loja, a compra do refrigerante, a lembrança de que aquele foi o momento em que tudo começou, a confusão mental, a voz infantilizada, o corpo encolhido. Os materiais heterogêneos dessa rememoração são reunidos tematicamente pelo mesmo tipo de relação com o universo infantil, mas não guardam um encadeamento temporal entre si. Não é preciso ir muito longe nesta descrição para notar que, no seu modo de desdobrar-se em relações não cronológicas entre imagens, o "fluxo de consciência" de Barbara Jean se assemelha à "livre associação", enquanto as reminiscências de que ele se compõe têm uma forma

${ }^{224}$ Como nos ensina Marx, sem a "acumulação originária", quer dizer, sem a expropriação dos meios de produção dos trabalhadores e sua concentração nas mãos de uma classe detentora de capital, não surgem e nem se conservam o capitalismo em geral e os seus setores particulares. MARX, Karl. A Chamada Acumulação Primitiva. In: O Capital, p. 825 - 879. Na condição de empreitadas capitalistas, as indústrias culturais também têm a "expropriação" inscrita no seu código genético e, no caso norte-americano, elas contaram com a disponibilização de saberes artísticos e técnicos pelo desemprego de um vasto número de trabalhadores culturais, no momento de seu surgimento. DENNING, Michael. The Cultural Apparatus. in: The Cultural Front. p. 38 - 50. Perdida em meio à consolidação da indústria fonográfica em Nashville, Barbara Jean dá provas da dificuldade de fazer a transição de um modo de produzir música semiartesanalmente para o profissionalismo do "Nashville Sound", experimentando como crise 
discursiva próxima de uma fantasia infantil encobridora. Como nos ensina Renato Mezan,

"as fantasias são produtos inconscientes, fruto de uma combinação - no sentido químico, isto é, por decomposição e fusão - de elementos pertencentes a várias vivências, de épocas diferentes. Freud nota [...] que as relações cronológicas estão ausentes no inconsciente, visto que a elaboração das fantasias nessa instância não as leva em conta, procedendo, ao contrário, à fragmentação das experiências: 0 desprezo pela cronologia serve aqui às finalidades da deformação."225

Antes de prosseguir, vale a pena notar, mais uma vez, a relação entre o trabalho colaborativo no set de Altman e os resultados estéticos alcançados. A heterogeneidade tanto interna, dos materiais que 0 compõem, quanto externa, em relação com a totalidade do roteiro, do monólogo de Barbara Jean, não pode ser apreciada corretamente sem que se tenha em mente o fato de se tratar de uma adição de "última hora". No roteiro original, Barbara Jean sofreria apenas mais um desmaio, contrariando as intenções de Ronee Blakley, que gostaria de ver os problemas de sua personagem alçarem uma nova etapa. Altman sugeriu então que ela, simplesmente, ficasse "catatônica" no palco, mas a atriz preferiu a solução que se vê no filme, elaborando um texto para Barbara Jean na noite anterior às filmagens.

"O colapso em forma de um confuso fluxo de consciência foi costurado a partir de detritos reais do álbum de família de Blakley, em Idaho. (O único detalhe emprestado foi o da avó estalando a dentadura enquanto ouvia o rádio, que ela tomou de Lily Tomlin). Blakley memorizou o texto e tratou de dormir um pouco, indo falar com Altman, na manhã seguinte, no escritório da produção. 'Nós estávamos nos aprontando para nos dirigir ao local de filmagem', recorda o diretor. 'Ela iria apresentar dois números musicais, mas não tínhamos nada escrito para ela falar. Ela chegou para mim e disse: - Escrevi uma coisa. Posso ler para você ver o que acha? Eu respondi: - Eu não tenho tempo pra isso. Vai lá e faz. Eu só vou te colocar no palco e você faz o que achar certo. Foi tudo criação dela.",226

psíquica o processo sempre renovado de "acumulação originária" que toda modernização pressupõe.

${ }_{225}$ MEZAN, Renato. Freud: pensador da cultura. p. 214.

${ }^{226}$ STUART, Jan. The Nashville Chronicles. p. $223-226$. 
A confiança de Altman na capacidade criativa dos atores resultou em uma das cenas de maior força no filme. O texto escrito espontaneamente, sem muito planejamento, destoa das falas corriqueiras da personagem, tensionando-as com sua forma de "colagem rápida" de materiais diversos, evocando "memórias encobridoras" de alguma experiência traumática.

Se o registro desta experiência se deu por deformação e ocultamento, então ela não poderá ser extraída diretamente do conteúdo manifesto do monólogo, devendo ser "adivinhada" a partir de outros dados. Como nos ensina Freud:

"[..] podemos dizer que o paciente não recorda coisa alguma do que esqueceu e reprimiu, mas expressa-o pela atuação ou atua-o (acts it out). Ele o reproduz não como lembrança, mas como ação; repete-o, sem, naturalmente, saber que o está repetindo."227

Ou seja, a porta de entrada para o dano psíquico causado na personagem não está naquilo que ela recorda e diz, mas sim no modo como diz e age; é a forma de suas ações e de sua fala, e não o seu conteúdo imediato, que atualiza em gesto a experiência traumática. Com isso, Freud aponta que o caminho a ser seguido pela análise é o da atuação de Ronee Blakley, sobretudo nos últimos segundos do monólogo, antes de ser retirada do palco. Disparada pela frase com a qual a consciência tenta "pinçar" o momento em que tudo começou ("Eu acho que desde então eu tenho trabalhado e feito a minha... sustentado a mim mesma."), uma sequência de gestos infantiliza a cantora até então segura de si: a voz quebrada, em tom infantil; o corpo encolhido, como se tivesse feito algo de errado; a tentativa inútil de esconder do marido o objeto estimado (o microfone); a voz consoladora, porém firme, do marido, transformado em figura paterna ao beijá-la na testa.

O brevíssimo "ato" entre "pai e filha" recupera uma cena mais longa, do começo do filme, em que Barbara Jean e Barnett têm uma 
briga por conta de Connie White, rival que a substituíra no Grand Ole Opry. Voltemos a ela:

Quarto de hospital repleto de flores. Luz baixa. Barbara Jean pinta as unhas, sentada com as pernas cruzadas sobre a cama. Barnett come alguma coisa, recostado em uma cadeira, ao fundo. No rádio, toca uma música baixa; é Connie White cantando ao vivo no Grand Ole Opry: "Eu sei que você me ama quando eu estou numa boa, / Me ama toda vez que eu te faço rir. $^{2228}$

Barbara Jean: desliga isso aí.

Barnett: Ok, só mais um minuto, querida.

Barbara Jean: Agora!

Barnett: Ela já está acabando.

Barbara Jean: (irritada) Eu quero que você desligue isso AGORA! Está me incomodando.

Barnett: Me incomoda também, mas eu tenho que ouvir.

Barbara Jean: Por quê?

Barnett: Porque eu tenho que ir ao King of the Road e agradecêla pessoalmente por você.

Barbara Jean: Agradecê-la?

Barnett: Mas primeiro eu tenho que saber quais canções ela cantou, não tenho?

Barbara Jean: Você pode perguntar para qualquer pessoa. Você pode telefonar (soluços), você pode mandar flores, mandar uma mensagem.

${ }^{227}$ FREUD, Sigmund. Recordar, Repetir e Elaborar (Novas Recomendações sobre a Técnica da Psicanálise II). in: O Caso Schreber, Artigos sobre Técnica e Outros Trabalhos. p. 165.

228 "I know you love me when I feel good/ love me every time I make you laugh." 
Barnett: Por favor, não vá ficar chateada agora.

Barbara Jean: Você está me fazendo estragar minha unha.

Barnett: Alguma vez eu já te disse como é que você deve cantar? Ahn? Alguma vez eu já te disse como cantar uma música?

Barbara Jean: Não é essa a questão. Eu sei por que você quer ir lá. (voz embargada) Você vai...

Barnett: Não tenta me ensinar como administrar a sua vida porque eu tenho feito um trabalho muito bom. (Contemporizando) Vamos nos acalmar. Nós dois estamos nos deixando nervosos.

Barbara Jean: Você vai ao King of the Road e eu sei por quê; é pra ficar se engraçando com todo mundo.

Barnett: Para eu fazer o quê?

Barbara Jean: E eu não tenho nenhum amigo.

Barnett: (irritado) Ficar me engraçando? Eu nem gosto desta expressão: "se engraçar".

Barbara Jean: Eu tenho que ficar sentada nesta droga de hospital, enquanto todos ficam falando que eu sou doida, que (zombando de si mesma) eu tive, Barbara Jean teve, outro colapso! Você quer saber? Aproveita e leva pra ela algumas das minhas flores.

Barnett: (calmo) Já acabou?

Barbara Jean: (levantando-se na direção das flores; a câmera a acompanha) Não, ainda não acabei. Por que você não manda pra ela esse lindo buquê preto; vai alegrá-la. Por que você não tenta estas daqui? E estas?

Corte para um plano próximo de Barnett. Alternância de tomadas próximas dos dois personagens. 
Barnett: Acabou? Eu perguntei se você ACABOU?

Barbara Jean desmorona sobre a cama. Com o rosto escondido entre as mãos, começa a chorar.

Barnett: Você está ficando doida? Porque se estiver, Barbara Jean, eu não vou tolerar. Ahn? Está tendo uma daquelas crises nervosas de novo? Ahn?

Barbara Jean: (sussurrando) Não!

Barnett: Pois você quase me enganou porque parecia que você estava pronta para mais uma. Agora, se acalma e se recompõe, entendeu? A única razão por que eu estou indo lá é que eu te amo. Eu não gosto de ir lá e ficar fazendo amizade com aqueles fingidos. Por que você me faz levantar a voz pra você? Por que você nos faz passar por tudo isso? Você está bem?

Barbara Jean: (gemido baixo).

Barnett: Vamos lá; um sorrisinho pro Barnett.

Barbara Jean: Estou cansada desse lugar.

Plano aberto dos dois personagens.

Barnett: Vamos lá. Você me ajuda e eu te ajudo, tudo bem? Vamos lá, vamos lá? Agora, aonde é que o Barnett está indo? Aonde eu estou indo? Ahn?

Barbara Jean: (caminhando lentamente de volta à cama; sussurra muito baixo) King of the Road.

Barnett: E por que eu estou indo lá?

Barbara Jean: (sussurrando) Para ver Connie.

Barnett: E por que eu estou fazendo isso?

Barbara Jean: (sussurrando) Para agradecê-la por cantar no Opry. 
Barnett: Agora, por quem eu estou fazendo isso?

Barbara Jean: (sussurrando) Você está fazendo isso por mim. (senta na cama)

Barnett: É isso aí. Agora eu vou saindo. O que é que você diz quando eu saio? Você diz 'tchauzinho'.

Barbara Jean: (totalmente descomposta) Tchau.

Barnett: 'Tchauzinho'. (passa de costas na frente da câmera e sai)

Barbara Jean: Tchau. (recobrando a posição de início, sentada na cama, pernas e braços cruzados) Barnett? Barnett??

Concentremo-nos, mais uma vez, na forma de atuação e na dramaturgia do diálogo. A cena pode ser dividida em três momentos: o delineamento de uma situação corriqueira entre marido e mulher (o rádio, as unhas), o desequilíbrio desse quadro a partir da exigência de que o rádio seja desligado, o reestabelecimento da ordem tradicional das relações entre os gêneros. É particularmente significativa a parte final da conversa, em que Barnett reconduz o corpo de Barbara Jean à posição inicial (sentada sobre a cama, pernas e braços cruzados) ao mesmo tempo em que "dirige" suas falas como quem repassa um "roteiro" repetitivo ("Agora, aonde é que o Barnett está indo? O que é que você diz quando eu saio? Você diz 'tchauzinho'"), cuja separação entre o "aqui e agora" do diálogo e as ocorrências anteriores a que ele se refere é um traço inconfundível da atuação épica.

Oferecendo uma forma adequada à representação dos colapsos nervosos da cantora e da violência com que seu marido lhe repõe a sanidade, a atuação épica encena a reativação compulsiva de um trauma edipiano, em que a "menina" é conduzida, por um "substituto paterno", da fantasia de onipotência à fantasia de dor pela privação do Falo ${ }^{229}$. A

${ }^{229}$ Sobre a forma e a resolução da crise edipiana na menina, ver o quadro explicativo proposto em NASIO, J. D. Édipo: o complexo do qual nenhuma criança escapa. p. 64. 
sobreposição simbólica entre a briga no hospital e o colapso nervoso no palco do Opry Belle é quase perfeita: as interrupções sucessivas da canção, agravando a impaciência dos músicos (todos eles homens), e a ordem para desligar o rádio, vinda da "provedora" da família, atualizam a crença em um desejo não contrastável; o marido que retira o microfone e paga com um beijo na testa, ou que violentamente quebra um vaso de flores e recorda quem manda em casa, substitui a figura do "pai repressor", aquele que subtrai os símbolos da potência fantasiada; a voz infantil e o corpo retraído na cama ou no palco gestualizam a dor pela privação dos objetos queridos (microfone e participação no programa de rádio). Já a recorrência dos colapsos, encenada ou referida no diálogo (“Está tendo uma daquelas crises nervosas de novo?"), dá forma narrativo-dramática ao funcionamento do mecanismo psíquico, que consiste na tentativa de controle da experiência dolorosa por meio de sua repetição compulsiva ${ }^{230}$.

É neste ponto que a cena carregada de símbolos do psiquismo encontra uma ancoragem na crítica social. Exaurida fisicamente pela rotina de shows - não custa lembrar a fala de Barnett no início da sequência ("Esse cara aqui está querendo que ela faça quatro shows") e o conselho de Del ("Não deixe que ela trabalhe demais") - Barbara Jean é vítima de sofrimentos neuróticos associados à dificuldade de lidar com as demandas do sistema econômico: o canto em troca de dinheiro, a administração empresarial de sua vida, as concessões desagradáveis ao mercado de celebridades, a angústia diante da possibilidade de perder espaço para suas concorrentes. Se a incapacidade de inverter a polaridade da dominação e recuperar o autocontrole pode ser lida como um sinal do fracasso de Barbara Jean em seu embate contra seus opressores, a recorrência de seus colapsos nervosos deve ser vista como

\footnotetext{
${ }^{230}$ Um exemplo do funcionamento deste mecanismo é dado por Freud no relato sobre a solução encontrada por um menininho de um ano e meio para lidar com a dor de "perder" a mãe quando estava se ausentava: brincando de "perder propositalmente" um objeto querido para depois encontrá-lo, o menino invertia a polaridade da ação de perder, deixando de ser sua vítima para tornar-se o seu sujeito, ao controlá-la e fazê-la ocorrer segundo a sua vontade. FREUD, Sigmund. Além do Princípio de Prazer. in: Além do Princípio de Prazer, Psicologia de Grupo e Outros Trabalhos. p. $25-27$.
} 
um indício da dificuldade do sistema de opressão em oferecer formas de sublimação que resultem em sujeitos funcionais. Embora não se possa negar que, na maioria das vezes, o comportamento que "no indivíduo é sintoma de neurose, no capitalismo é normal e socialmente desejável para o funcionamento da sociedade" ${ }^{\text {231 }}$, o desmoronamento psíquico da cantora, cuja vida é administrada como uma empresa capitalista, não deixa de ser uma figuração, na pequena "unidade econômica", de uma instabilidade do sistema com um todo. $\mathrm{Na}$ mistura delirante entre memórias pessoais e falas ensaiadas, descobre-se que o domínio da indústria cultural atingiu o inconsciente; na perda da funcionalidade da cantora, é possível ver este domínio vacilar.

Diante deste quadro, a plateia "ressabiada" desde o falso idílio do "cowboy operário" se impacienta e reage com violência, reclamando e vaiando ruidosamente, enquanto Barbara Jean é retirada do palco, não sem antes lançar um olhar mortificado na direção do público. Cabe a Barnett tentar acalmar a situação:

"Tudo bem, tudo bem. Ah, espera aí, gente! Tenham um pouco de compaixão! Está muito cedo ainda. Vocês têm que saber... (uma bola de papel é lançada ao palco, passando perto de Barnett) ah, espera aí! Você não quis fazer isso, quis? Aquela menininha ali acabou de sair do hospital (músicos começam a tocar, tentando abafar as vaias. Barnett fala aos músicos). Ah, espera aí, rapaziada! Segura aí. (As vozes se tornam mais violentas; uma tomada da plateia mostra um homem muito agitado, reclamando e apontando o dedo na direção do palco). Eu sinto muito, mas aquela garotinha agora está lá dentro se debulhando em lágrimas porque ela não queria ter desapontado vocês. (As reclamações ficam ainda mais intensas; um plano próximo de Barnett mostra um rosto pensativo, como se pesasse suas opções; olha para o fundo do palco, onde estão Del e Triplette, e fala à plateia) Vocês todos vão amanhã ao Parthenon, no Centennial Park, e verão Barbara Jean de graça, como nossos convidados. O que acham? (Mistura de vaias e aplausos) Tudo bem? Muito bem, agora vamos ouvir uma salva de palmas pela melhora de Barbara Jean. Vamos lá! Quero ouvir."

${ }^{231}$ Avaliação que Harry Braverman faz do comportamento obsessivo-compulsivo de Frederick Winslow Taylor, engenheiro que aplicava em sua vida pessoal os princípios de administração que formulou, contando seus passos e analisando seus movimentos cotidianos de modo a atingir o máximo de eficiência. BRAVERMAN, Harry. Labor and Monopoly Capital. p. 92. 
Tomada da plateia: a maioria aplaude, mas o homem irritado ainda gesticula muito, apontando os dois polegares para baixo em sinal de reprovação. Barnett põe o microfone no tablado e caminha agitado na direção de Triplette e Del. A banda recomeça a tocar.

Barnett: Ingratos, é isso que eles são. Um bando de... eu caí numa armadilha e vocês dois sabem muito bem disso.

Triplette: Sabemos que você caiu, Barnett.

Barnett: Eu quero regras claras agora.

Triplette: É você quem manda.

Barnett: Ela vai cantar primeiro, certo? Ela vai sair antes mesmo daquele homem chegar.

Triplette: Tudo bem. Tudo o que você quiser, do jeito que você quer.

Barnett: Eu nunca devia tê-la trazido aqui. Sem parafernália, sem literatura circulando, entendeu? E nunca, em nenhum momento, ela deverá ser associada a Hal Phillip Walker, ou seja lá qual for o nome dele.

A plateia, agora, já não é composta apenas pelos espectadores reais que Altman conseguiu atrair ao Opry Belle; ela foi adensada por ruídos de aplausos e vaias adicionados na mixagem, figurando uma massa heterogênea de gente ordeira e outros tantos ciosos do dinheiro pago por um show que não aconteceu. Se, em assuntos políticos, ela foi frequentemente descrita como uma "maioria silenciosa", desinteressada no processo eleitoral (no Parthenon, aonde ela comparece como convidada de Barnett, cantará, alegremente, "Podem me dizer que não sou livre, mas eu não estou nem aí"), no momento em que sente seus hábitos de consumo ameaçados, ela se transforma em turba ruidosa e até mesmo violenta, lançando não apenas vaias (a maior injúria que um artista pode receber), mas também objetos, ao palco. Tendo pagado por mais um "tranquilizante" da indústria cultural, a plateia se descobre 
vítima de um engodo: em vez de ser consolada pela dureza da vida cotidiana, ela é constrangida a consolar a cantora em estado de ruína, transformada em criança no palco ("Eu sinto muito, mas aquela garotinha agora está lá dentro se debulhando em lágrimas porque ela não queria ter desapontado vocês").

$\mathrm{Na}$ sua fala de louca, Barbara Jean relatara uma infância às voltas com animais domésticos, ouvindo o rádio e cantando em troca de alguns centavos, o que evidencia, para o ponto de vista do público, o reconhecimento de um alinhamento de classe resultante de uma "experiência plebeia" compartilhada. Esse conceito de uma "cultura plebeia", unindo star e público em um acordo tácito, proposto por Michael Denning, ajuda a explicar não apenas a rejeição de Barbara Jean nesta cena, mas também a teoria do assassinato político encenada no Parthenon, cuja premissa poderia ser assim resumida: no momento da sobreposição entre cultura comercial e experiência política, o star passa a ser um alvo tão visado quanto os políticos tradicionais. Citando C.L. R. James, Denning sugere que o star

"'não é, em qualquer sentido, uma simples criação de industrialistas predatórios para o consumo das massas estúpidas [...], mas um produto da época contemporânea'. 'Nenhuma publicidade do mundo pode criar um star, é a massa quem escolhe seus grandes stars com incrível discernimento'. Como as massas escolhem seus stars continua sendo uma pergunta difícil de responder na história cultural, mas dois aspectos parecem claros. Em primeiro lugar, o star, assim como o político, conquista a lealdade e a aliança do público por meio de uma pretensão implícita ou explícita à sua representação. Frequentemente, essa pretensão resulta do peso simbólico da origem social do star. [...]. Entretanto, o star não precisa vir 'do povo' para representá-lo. Muitos stars [...] conquistaram a lealdade do público representando estilos e papéis plebeus [...]. O estrelato é parte de uma luta por hegemonia, parte dos modos como instituições sociais e movimentos criam um consenso. Com isso, o star não deve ser encarado como uma simples tendência a 'reforçar a ideologia cultural dominante... ou esconder importantes tensões culturais'. Embora essa visão seja frequentemente verdadeira, ela subestima não apenas a fragilidade do estrelato [...] mas também o seu lugar nas lutas populares." 232

${ }^{232}$ DENNING, Michael. The Cultural Front. p. $154-155$. 
Tomado neste sentido, o colapso da cantora é mais do que uma simples falta com o compromisso marcado; ele é também a ruptura de um acordo tácito. Para a plateia excluída do trabalho artístico e forçada à posição de espectadora, a visão de Barbara Jean fraquejando diante das exigências do sistema revela sua inadequação para representá-la. Posta no centro da atividade especular, a sua imagem de figura "vampirizada" pelo sistema não reflete os anseios e demandas do público, mas amplia seus sofrimentos e frustrações até o limite do suportável, devendo então ser violentamente atacada e removida do campo de visão. Uma vez roto o laço de confiança, o destino de Barbara Jean está selado; inadvertidamente, Barnett convida a plateia a assistir ao fim da cantora no Parthenon.

Do ponto de vista simbólico, o gesto da plateia ajuda a despi-la da roupagem de proteção contra os avanços do aparato políticocultural acionado pela campanha de Walker. O estrelato de Barbara Jean, assim como qualquer carreira política, não se sustenta sem o cuidado com sua reputação; para não manchá-la com a pecha da imprevisibilidade e da inconstância, Barnett se vê forçado a aceitar o risco de endossar o candidato à presidência. Nas próprias palavras do personagem, a cantora "caiu em uma armadilha". Com a retórica típica da fala comercial, Triplette dissipa as inquietações de Barnett, fingindo aceitar condições que, mais tarde, abandonará despudoradamente. E assim, a ruptura que destitui Barbara Jean do posto de representante de uma classe obriga sua aliança com um aparato que a esmagará.

Corte abrupto para a casa de Linnea. O telefone toca. Pela terceira vez, é Tom, o atraente astro da música tentando seduzi-la. Até então firme nas suas recusas, Linnea emudece e apenas escuta o convite, quase ultimato, como se pesasse suas opções:

Tom: (do outro lado da linha) Ouça, eu vou fazer uma pequena apresentação hoje à noite no centro da cidade. Você não quer vir me encontrar? É um lugar chamado "Sem Saída", "Saída", ou alguma coisa assim. Bom, fica do outro lado da rua, de frente 
pro Friday's, na Church Street. Você sabe onde é, não sabe? Bom, eu vou estar lá por volta das oito e... por que você não me encontra lá? OK?

A sedução de Tom se dá nos termos da mercadoria. Jovem, bonito e famoso, ele telefona continuamente a Linnea, tentando arrancála do espaço doméstico para o lugar do consumo de seu corpo: a casa de shows e, eventualmente, o quarto de hotel. Até este ponto, Linnea é caracterizada como uma mãe de família "responsável". De fato, as primeiras investidas de Tom a encontram às voltas com obrigações domésticas: um jantar de última hora a pedido do marido e os cuidados com os dois filhos pré-adolescentes. A combinação entre a juventude atraente e maliciosa de Tom com a vida insossa da mulher casada mais velha aproxima a sedução inoportuna de um convite simbólico ao incesto. A princípio Linnea resiste, agarrando-se às responsabilidades de dona de casa, mas a terceira tentativa a encontra sozinha. Inebriada pela voz que a atrai para uma armadilha - a troca do nome do bar, de "Exit Inn" ("Taverna Exit") para "No Exit" ("Sem Saída"), é o lapso que denuncia o estratagema - ela aparenta pesar "opções"; mas, diante da oferta de uma "transgressãozinha" inconsequente pelo homem mais desejado da cidade, só há uma ação possível.

Corte para um plano da plateia lotada do Exit Inn. O público, na sua maioria mulheres, é uma mistura "de frequentadores locais com a equipe de produção de Nashville". No palco, o guitarrista veterano Jonnie Barnett, fazendo uma participação especial no filme, canta um de seus versos mais melosos ("Bem, é triste, mas verdade, que a luz que guia nosso amor aos

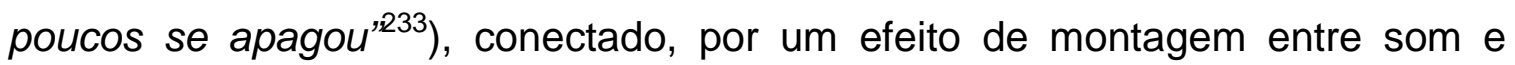
imagem, ao tema do abalo no casamento de Bill e Mary. Opal e Norman completam a mesa do casal em crise. Já um pouco amolecida pelo álcool, Opal pede outra bebida a Norman ("Ei, motorista, você pode me dar um pouco mais de champanhe?"), mas é logo repreendida por Bill, que lhe cochicha ao ouvido: "O nome dele é Norman; ele não gosta de ser chamado de 'motorista'". A

233 "Well, it's sad, but true, the pilot light of our love has flickered out." 
chegada de Linnea ao local dá a resposta ao convite que a cena anterior deixou no ar. No palco, Jonnie Barnett canta o estribilho ("Pois meu amorzinho está cozinhado na panela de outro homem" ${ }^{\text {"34 }}$ ) que sublinha dois triângulos amorosos, um existente e outro em potencial: Bill, Mary e Tom; Tom, Linnea e Del. Acanhadamente, Linnea se aproxima de uma cadeira vazia na mesa de Tom, mas Martha é mais rápida e toma sua frente:

Martha: Você já esteve no banheiro feminino daqui?

Tom: Não!

Martha: Eu estou sozinha aqui no Exit Inn, sem nenhum lugar melhor para ir.

Linnea senta-se a uma mesa no fundo do bar. No palco, Jonnie Barnett prossegue: "Bom, se fazer amor fosse igual a margarina, então ela seria a marca mais cara. ${ }^{235}$ Como se respondesse à letra da canção, Wade, um homem negro e pobre, tenta se aproximar da mulher branca e rica, oferecendo, justamente, pagar sua conta.

Linnea: (falando a uma garçonete) Eu vou querer uma sidra.

Wade: (na mesa ao lado) Ponha na minha conta.

Linnea: Não... hmm, tudo bem. E você poderia colocar num copo de vinho?

Wade: (à garçonete) Ponha num copo de vinho e ponha na minha conta.

$\mathrm{Na}$ mesa de Bill, Opal relata como ela e Tom se conheceram "no sentido bíblico", desconcertando Mary, amante de Tom. Bill esclarece o comportamento sexual de Tom: "Mary e eu sempre acampamos no mesmo quarto; Tom acampa em muitos quartos". Embriagado, Wade se apresenta e toma assento, sem ser convidado, ao lado de Linnea, que responde

234 "Since my baby's cooking in another man's pan." 
com educação, mas retrai o corpo, em claro sinal de repulsa. O vocalista convida Tom ao palco e o cantor estende o gesto a Mary e Bill, seus companheiros de banda. Aplaudindo e cantando, o público pede "It Don't Worry Me" ("Não estou nem aí"). Mary sobe ao palco, despe-se de um casaco azul e o pendura no pedestal do microfone, lançando-se em um estribilho no qual derrama toda a tristeza pela separação de Tom: "Desde que você se foi, meu coração se partiu mais uma vez." ${ }^{236}$ A autoria da canção é do ator Gary Busey, que "desistiu de interpretar Tom em favor de uma participação em um programa de TV"237, não sem antes fazer esta pequena contribuição ao filme. Desafinada e cheia de erros, incluindo uma tossida entre um verso e outro, a performance genuinamente nervosa de Cristina Raines (Mary) fica abaixo daquela de outros atores/cantores no filme. Eventuais preconceitos musicais do espectador, como uma possível crença num talento inato dos negros para o canto, são frustrados ainda pelo desempenho sofrível de Wade, tentando acompanhar, de sua mesa, o número de Mary. Constrangida e visivelmente impaciente, Linnea esconde o rosto entre as mãos. Sozinhos na mesa de Bill, Opal e Norman conversam:

Norman: (falando descontroladamente) Quando acabar isso aqui, eu vou levar os dois de volta para algum lugar e o que eu poderia fazer é te mostrar um pouco de Nashville. Eu poderia te dizer coisas que te fariam subir pelas paredes. Eu não estou brincando. Eu conheço, bem, eu conheço, por exemplo...

Opal: (interrompendo-o) Ahn, qual é mesmo o seu nome? Eu esqu...

Norman: (apontando para o seu crachá) Norman.

Opal: Sim, Norman. Por favor, Norman, eu faço questão de evitar conversa fiada com serviçais.

Aplausos.

235 "Well, if making love were margarine, she's the high-priced spread."

236 "Since you've gone, my heart 's broken another time."

${ }^{237}$ STUART, Jan. The Nashville Chronicles. p. 89. 
A sequência se liga à anterior por meio de uma progressão narrativa simples: o convite de Tom cria uma expectativa em relação a acontecimentos futuros, encorajando o espectador a antecipá-los na forma de hipóteses; na próxima cena, a chegada de Linnea ao local do encontro permite testar tais hipóteses, sugerindo uma elipse temporal, entrementes. Nesta segunda sequência, o foco narrativo explora o tema da sedução e dos triângulos amorosos, pontuando, com a pieguice de duas canções enlatadas, relações entre gêneros, marcadas por tensões raciais e de classe. O star atraente é unanimidade entre as mulheres; cobiçado por Mary, Opal, Martha e Linnea, ele se apresenta como um objeto de desejo eternamente disponível. Entretanto, a oferta de sexo rápido no banheiro do clube com a moça com aparência hippie ("Você já esteve no banheiro feminino daqui?") não parece deixá-lo animado. No canto do bar, Linnea, a vocalista branca do coral negro, parece assustada com a figura de Wade, um negro pobre, sem talento musical, com quem ela tem de lidar, fora do espaço seguro do estúdio de gravação. Contudo, é no diálogo entre Norman e Opal que a impossibilidade do amor entre classes ganha a forma de uma demarcação violenta de posições: com seu sotaque inglês, a jornalista, cujo trabalho precário a coloca numa situação econômica próxima à de Norman, responde, petulantemente, ao gracejo meio "cafajeste" do motorista, distanciando suas pretensões de "Don Juan" com uma palavra de ataque retirada do vocabulário de classes britânico - "servant", ou seja, "criado", "serviçal". Assim, valendo-se das possibilidades de construir argumentos por meio da combinação inusitada entre imagens e canções diegéticas, a narração vai analisando a linguagem e os códigos gestuais do amor e da sedução no momento em que estes se adequaram à forma-mercadoria. A próxima sequência desdobra novos aspectos desse argumento.

Fusão entre os aplausos deixados ao fim do número de Mary e aqueles que anunciam a próxima sequência, sem contiguidade espacial ou continuidade temporal em relação aos acontecimentos no Exit Inn. Plano próximo de uma cortina vermelha, em cuja fenda se assoma o rosto de Albuquerque, comendo alguma coisa cuja textura se assemelha à de um grande 
pedaço de carne assada. Corte para um plano aberto do ambiente: um clube noturno em forma de arena, com pequeno palco no meio e várias mesas ao redor. O público é exclusivamente masculino, na maioria respeitáveis senhores de meia-idade, todos vestindo terno e gravata. A composição é claustrofóbica: posicionada no meio da plateia, a câmera tem seu campo de visão obstruído por algumas cabeças na borda do quadro, pela baixa iluminação e por uma pilastra no centro da imagem. Ocupando a arena, Del faz as funções de mestre de cerimônias, falando à plateia, enquanto Triplette o observa, a partir de uma posição periférica:

"Ok, meus amigos, eu acho que vocês têm um ótimo candidato para apoiar aqui. Eu não vou tomar muito do seu tempo, porque temos uma diversãozinha pra vocês. Na mesa, tem cartões promissórios [pledgle cards]; vocês podem se comprometer com a quantia que quiserem e eu me certificarei de que pagarão mais tarde. E se tiverem um cheque no bolso, não fiquem com medo de preenchê-lo. Eu vou levá-lo para o banco antes que vocês consigam sustá-lo. Qualquer quantia em dinheiro, qualquer coisa; não fiquem acanhados e nada de humildade. É só isso. E enquanto vocês escrevem, para ninguém ficar entediado ou coisa assim, está vindo aí uma coisinha para mantê-los ocupados. (Bateria introduz os primeiros acordes de 'I Never Get Enough). Só não se esqueçam de olhar para cima (aponta naquela direção), porque coisas boas vêm das alturas."

Tomada contre-plongée extremamente angulada. De um alçapão no teto do clube, desce uma espécie de pedestal mecânico. Aplausos, assobios e algazarra generalizada. Sobre este pedestal, o foco narrativo vai desvendando, de baixo para cima, o corpo de Sueleen, coberto por um figurino de show: vestido verde de mau gosto, uma máscara de carnaval atada a um cabo seguro na mão coberta por luva prateada, na mesma cor das franjas do vestido; na cabeça, um capuz estilo "Chapeuzinho Vermelho", feito do mesmo tecido do vestido, atado na altura do pescoço, deixando ver um decote sensual.

"Oi pra todo mundo! O meu nome é Sueleen Gay e eu vim aqui hoje cantar uma música sobre uma garota que nunca está satisfeita." 
Aplausos delirantes da plateia diante da promessa de Sueleen. Em um canto do clube, o olhar de Bud se acende, enquanto Del ri com excitação perversa. Triplette apenas olha com curiosidade distante. $\mathrm{Na}$ arena, Sueleen tira a máscara, baixa o capuz até os ombros e começa a cantar, completamente fora do tom.

"Nunca me satisfaz, nunca me satisfaz, o amor por que estou faminta.

Nunca me satisfaz, nunca me satisfaz, eu quero sempre mais e mais.

Mesmo se ficarmos juntos nossa vida inteira,

Eu quero sempre mais, eu quero sempre mais você.

Não cobiço uma mansão na colina, nunca fui este tipo.

Não preciso que estufem meus bolsos com notas de cem. ${ }^{, 238}$

A cantora passa atrás de uma pilastra e faz um gesto amplo com as mãos, traçando um coração imaginário, de cima para baixo, do meio do decote até a altura do sexo. Caminha pelo espaço cênico requebrando desajeitada, enquanto a banda, revelada por um movimento panorâmico da câmera, se esforça para acompanhá-la. Em um plano "intimista", Del e Triplette comentam a performance:

Triplette: Ela é a pior cantora que eu já ouvi.

Del: (rindo, maliciosamente, como se a falta de traquejo da moça o excitasse) Ela não canta porcaria nenhuma.

Sem uma relação de causalidade narrativa entre si, os acontecimentos representados no Exit Inn e no clube de strip-tease tornam-se

\footnotetext{
238 "I never get enough, I never get enough of the love I'm hungry for./ I never get enough, I never get enough, I always want more and more./ Even if we stay together our whole lifetime through,/ I'll never get enough, l'll never get enough of you./ I ain't greedy for that mansion on the hill, I never was that kind./ Don't need my pockets stuffed with hundred dollar bills".
} 
coerentes pela intervenção da montagem paralela, configurando a progressão de um tema - o desejo mediado pela forma-mercadoria - observado a partir dos pontos de vista do trabalho artístico profissional e amador. No show de Sueleen, estes pontos de vista são articulados como contradições da cena. A cantora não percebe que se encontra em um ambiente hostil, onde a banda profissional que tenta acompanhá-la só faz sublinhar o amadorismo de seu canto; chegando mais tarde ao encontro marcado para despi-la, Sueleen não pode apreciar o quão cínica se torna a confissão de desapego material de seu verso ("Não preciso que estufem meus bolsos com notas de cem") diante do apelo feito, segundos antes, por Del: "E se tiverem um cheque no bolso, não fiquem com medo de preenchê-lo. [...]. Qualquer quantia em dinheiro, qualquer coisa; não fiquem acanhados e nada de humildade". Assim, a letra da canção produz um efeito irônico que se volta sobre a personagem: enquanto Sueleen canta os anseios amorosos de um "eu-lírico" feminino apaixonado, a plateia lê a confissão de um apetite sexual insaciável ${ }^{239}$.

Tais leituras contraditórias relacionam-se com a compreensão divergente do gênero de representação por público e artista: enquanto Sueleen pretende que a retirada da máscara dê um toque de sensualidade apenas sutil ao show musical teatralizado, seus espectadores decodificam o gesto como o prólogo descarado de um strip-tease. Essa ironia involuntária pode ser atribuída também à falta de preparação técnica da personagem, que não consegue fazer uma composição coerente entre figurino e coreografia, produzindo ambiguidades, excitando uma sexualidade perversa com a citação a "Chapeuzinho Vermelho" no desajeitado capuz, e involuntariamente fazendo um convite ao sexo com o movimento das mãos que desenham um coração sobre o corpo. Porém, o fundamento de base da divergência de pontos de vista são antagonismos de gênero e de classe: jovem, pobre e mulher, a amadora tenta a sorte no palco, tornando-se o objeto do

${ }^{239}$ A letra é propositalmente "mal feita" para representar o amadorismo de Sueleen no trabalho de composição. Para tanto, diferente de outras canções no filme, sua elaboração foi confiada a músicos profissionais: o letrista Ben Raleigh e Richard Baskin, o diretor musical do filme. 
desejo e de comentários maldosos de homens ricos de meia-idade, confortavelmente sentados nas porções escuras do cenário, de onde podem observá-la, medi-la e avaliá-la.

O "estudo da plateia", iniciado com o público genuíno atraído às filmagens no Opry Belle e enriquecido com a mistura de personagens, membros da equipe de produção e frequentadores locais do Exit Inn, chega ao termo no grupo de respeitáveis residentes de Nashville que aceitou atuar como a turba ruidosa que aplaude e assobia para Sueleen. Convencê-los não foi fácil, pois ninguém queria aparecer na tela de cinema fruindo um strip-tease.

"O socorro, mais uma vez, veio de Thomas Hal Phillips [o autor dos discursos de Hal Phillip Walker], que atraiu trezentos homens da elite de Nashville com a promessa de uma viagem à Disneylândia e um aparelho de TV de graça." 240

Incorporados ao universo diegético, esses moradores reais de Nashville contribuíram para a elaboração de uma imagem contraditória da classe financeira da cidade; uma fração desta classe - membros da Câmara de Comércio - já fora anunciada na reportagem de Bill Jenkins no aeroporto, mas é só agora que a narração a oferece ao escrutínio do espectador como um agrupamento mais amplo, em um momento de descontração. Invariavelmente trajados de terno e gravata, os homens de quem Del e Triplette dependem para o financiamento da campanha de Walker são avaliados pelo foco narrativo como uma massa civilizada e bárbara a um só tempo; a roupa "grã-fina", a deferência do tratamento que recebem, o volume de dinheiro no bolso, são alguns sinais de que estes sujeitos representam as "classes educadas" da cidade; a algazarra, os assobios, os aplausos impacientes e os comentários maldosos são os comportamentos exibidos em grupo por esta gente, protegida por um tipo de iluminação e por um posicionamento cênico que reproduzem sua situação social privilegiada. A orientação épica da cena torna-se evidente quando o foco narrativo se dirige sobre a plateia genuína incorporada à diegese, transformando

${ }^{240}$ STUART, Jan. The Nashville Chronicles. p. 245. 
o set de filmagem em "laboratório" de análise, teste e estudo de pontos de vista de classe, dentro de condições de controle estritamente artísticas.

$\mathrm{Na}$ atuação precisa de Gwen Welles, interpretando a amadora desafinada e desajeitada, é possível reconhecer o trabalho de "direção de atores" de Altman. Nos comentários gravados e sobrepostos à cena, como "extras" do DVD do filme, Altman lembra como é difícil conseguir, de atores profissionais, uma representação convincente do canto desafinado. No caso de Welles, a situação era agravada pelo fato de ela ser, efetivamente, uma má cantora:

"Nós queríamos que ela soasse exatamente como ela era, mas, se você tem uma pessoa que não sabe cantar e tenta fazê-la cantar mal, ela simplesmente não consegue. $O$ efeito que se quer é o de alguém que está fazendo o máximo para cantar bem, mas não tem talento para isso." 241

A solução encontrada foi oferecer três meses de aulas de canto a Welles, conseguindo que sua personagem efetivamente parecesse uma amadora esforçada, mas sem nenhuma possibilidade de aproveitamento como cantora. Dirigindo a atriz em uma "interpretação negativa" de seu papel, Altman Ihe auxiliou a representar, em vez do canto ruim, a inutilidade do esforço de cantar bem, pois o tipo de espetáculo para o qual a personagem tenta vender sua "arte" já Ihe atribuiu uma função que torna irrelevantes as suas qualidades vocais.

"Temos [aqui] uma atenção, tipicamente brechtiana, à visão dialética dos conselhos clássicos de Stanislavski: o ator que representa um bêbado no palco não deve mostrar a volubilidade e a voz pastosa, mas sim os esforços para andar na linha reta e parecer sóbrio. $O$ ator que representa o homem mesquinho, deve mostrar os esforços para parecer generoso. Não representar a raiva, mas a tentativa de controlá-la.."242

241 Nashville. Dir. Robert Altman. Paramount Pictures. Hollywood, 2000. (Widescreen DVD Collection).

${ }^{242}$ CARVALHO, Sérgio de. Ações físicas segundo Stanislavski e Brecht. in: CARVALHO, Sérgio de (org.). Introdução ao Teatro Dialético. p. 82. 
Embora o canto de Sueleen seja consideravelmente inferior ao de Tom, ela não se sai muito pior do que Mary, de modo que a intervenção engenhosa de Altman resulta numa crítica da mobilização contraditória que o show business faz do trabalho profissional e do trabalho amador, expondo no processo a flexibilidade de seus critérios estéticos. A voz desagradável de Mary pode ser adequada se ela vier a aumentar as possibilidades mercadológicas de uma banda excessivamente masculina; entretanto, um tipo parecido de voz se torna um fato imaterial quando aquilo de que se necessita é apenas o corpo feminino como atração principal de um smoker.

"Smoker" é a palavra usada por Triplette para descrever o evento de campanha que organiza, justamente na conversa em que acerta a contratação de Sueleen. O termo, que designa um tipo de festa "apropriada apenas para homens" ${ }^{243}$, tem conotações políticas, pois se trata de uma ocasião para confabulações masculinas, e está ligado à história oculta do cinema; como lembra o narrador de A History of the Blue Movie (Alex de Renzy, 1970), os negócios de pornografia (do grego porne, "prostituta", e graphein, "escrever" ${ }^{244}$ ) acompanham a indústria cinematográfica mainstream desde seus primeiros passos, na virada do século XIX para o XX. Aproveitando os momentos de ociosidade do aparato técnico e de seus profissionais para filmar esquetes em bordéis, os primeiros comerciantes de pornografia fílmica exibiam seus curtas-metragens em concorridas festas privées chamadas "smokers" ou "stag parties". Na medida em que Del oferece o corpo de Sueleen em troca de apoio político e financeiro, o "olhar da câmera" registra um ato de prostituição, oferecendo ao espectador a encenação de um gozo pornográfico, que ele contempla de uma posição próxima dos participantes do smoker. Deste ponto de vista incômodo, vemos Sueleen descer requebrando sobre um pedestal, coisificada numa frase (“Coisas boas vêm das alturas”) cuja ambiguidade lembra

\footnotetext{
${ }^{243} \mathrm{http}: / /$ www.audioenglish.net/dictionary/smoker.htm, consultado em 05/12/2012.

${ }^{244} \mathrm{http}: / /$ www.etymonline.com/index.php?term=pornography, consultado em 05/12/2012.
} 
a sobreposição de mascaramentos sexuais e religiosos típica do fetichismo ${ }^{245}$. Ao contrário da cantora, sabemos que o sentido de sua descida não se esgota no mero deslocamento físico; diante dos riscos que a prostituição representa para uma sonhada carreira nas indústrias culturais, a entrada da personagem no ambiente lúgubre e claustrofóbico, onde é recebida com algazarra e sorrisos perversos, anuncia, na simbologia da passagem pelos submundos infernais do show business, uma queda moral e uma perda de valor de mercado. Nessa primeira passagem do foco narrativo pela cena, só podemos pressentir, no movimento que vai do alçapão no teto do clube à arena rodeada de olhares cobiçosos, que a personagem sonhadora está pisando em uma armadilha.

Os aplausos para Sueleen se fundem, novamente, com aqueles deixados ao final do número de Bill, Mary e Tom no Exit Inn, sugerindo que as sequências paralelas não seguem a mesma temporalidade. Enquanto Sueleen cantava "I Never Get Enough", a narração mantinha a outra linha de progressão "em pausa", para retomá-la, agora, no momento em que Bill e Mary deixam o palco. Petulantemente, Tom atira na direção de Mary o casaco que ela esquecera pendurado sobre o pedestal do microfone. Cumprida sua função para a cena, Wade pede licença e se retira, não obtendo uma resposta de Linnea, que apenas o acompanha com o olhar. Fora do campo, a voz de Tom anuncia: "Tudo bem; se vocês quiserem mais, vai ter de ser só comigo, porque parece que eu acabei de ser abandonado". O foco narrativo se dirige a Linnea: enquadrada pela moldura "sufocante" de rostos fora de foco, no primeiríssimo plano, ela segura o queixo com uma mão, parecendo desanimada com as possibilidades que a noite Ihe reserva. Fora do campo, Tom continua: "Eu vou tocar uma música que acabei de escrever e que vim gravar aqui". A fala chama a atenção de Linnea, que faz um movimento com os olhos na direção do palco.

\footnotetext{
${ }^{245}$ O primeiro uso conhecido do termo "fetiche" para descrever objetos encobridores se deu no campo da crítica da religião: "Os negros da costa ocidental da África, [...] têm por objetos de adoração certas divindades que os europeus chamam de Fetiches, termo forjado por nossos comerciantes do Senegal a partir da palavra portuguesa Feitiço, quer dizer, coisa feérica, encantada, divina ou que proporciona oráculos." BROSSES, Charles de. Du Culte des Dieux Fétiches. p. 15.
} 
Corte para um plano da mesa de Bill. Quase de costas para o palco, para onde olha por cima do ombro, Mary também foi despertada pela promessa de uma canção. À direita, com metade do corpo fora do enquadramento, se assoma a imagem de Opal. Voz de Tom, sobreposta a um close-up de Opal: "E vou dedicá-la a alguém muito especial que talvez esteja aqui nesta noite". Lisonjeada, a jornalista baixa a cabeça, certa de ser o "alguém" referido na dedicatória. Começa a introdução de "I'm Easy", no violão.

Plano próximo de Martha, emoldurada por duas anônimas. Fumando um cigarro e sorrindo na direção do palco, ela faz um gesto repetido por outra mulher no fundo da imagem; ambas parecem sentir-se a "musa" da canção. Martha olha para a direita e para a esquerda, buscando certificar-se de que o astro realmente canta para ela. Dá uma tragada em seu cigarro, soprando a fumaça, em um gesto soberano. No extracampo, a voz de Tom sobrepõe-se ao violão: "É uma canção chamada 'l'm Easy'”.

Corte para Linnea, no fundo do plano, ouvindo os primeiros versos: "Eu não sou de amar só quando não tem ninguém olhando". Contracampo: Tom no palco, de cabeça baixa, concentrado no violão. Em movimento suave, a câmera vai-se ajustando para separar sua imagem dos vultos que formam o enquadramento e permitir que o espectador se concentre na letra da canção:

“Eu não sou de pegar sua mão se eu não tiver certeza.

Eu não sou de deixar você ver o que se passa dentro de mim.

Quando não é de amor que você precisa, você não é livre.

Por favor, não puxe a minha manga se for só pra ficar brincando,

Se você não quiser aceitar aquilo que me pede.

Eu nunca gostei de joguinhos e este aqui está me enlouquecendo." 
Close-up de Mary, absorta na música de Tom: "Você não tem metade da liberdade que diz ter." Close-up de Opal: olhando para o palco com ternura, ela suspira profundamente, quase chegando às lágrimas. Partes de corpos femininos (uma orelha anônima, a mão de Martha) formam o enquadramento. "Mas estou sossegado, estou sossegado. É só dizer e eu jogo seu jogo, como se fosse..." Plano próximo de Martha, dando uma tragada no cigarro, enquanto acompanha a música com um movimento de ombros: "...a coisa a ser feita, porque estou sossegado." Corte para a imagem de Linnea, passando de confusa a emocionada, conforme Tom aumenta o volume da voz e o investimento dramático na sua interpretação. O verso é do cantor, mas seu sentido é espelhado, pois o aviso contido na mensagem aponta contra ele próprio: "Não me provoque, se você não pode me levar a lugar algum; se te amar for coisa de uma vez só."

Contracampo: plano próximo de Tom. A horizontalidade da composição visual (o palco, um enorme braço de violão pintado sobre a parede, no fundo) é sublinhada conforme a câmera vai fechando sobre o rosto do cantor, fazendo-o aproximar-se da linha superior da tela e criando uma coincidência entre a imagem e o sentido da letra: "Não posso pôr grades no meu interior, meu amor é algo que não sei esconder. Ainda dói quando lembro as vezes que tentei." Pela primeira vez, Tom olha para o público, supostamente na direção de Linnea: "Mas estou sossegado, estou sossegado." Corte para Linnea (um contracampo do olhar de Tom?): "Pegue minha mão e me abata; não vou resistir, porque..." Contracampo: olhar em off de Tom concentrado em algum ponto da plateia: “...estou sossegado.”

Close-up de Mary, tentando conter um sorriso. Vira-se para sua esquerda por sobre seu ombro. Um leve movimento panorâmico na direção de sua mirada faz Opal surgir no enquadramento. Surpreendida pelo encontro de seu olhar com o de Mary, em um misto de decepção e embaraço, Opal se volta para o palco e logo em outra direção, como a procurar a verdadeira "interlocutora" de Tom. Mary volta para a posição inicial e passa a 
mão pela boca, onde ainda se conserva um sorriso de escárnio. No extracampo, a letra da canção forma novas constelações com a imagem: "Não me faça favores, deixe-me olhá-la à distância, pois quando você está perto, eu tenho dificuldade de manter o controle." Plano próximo de Martha encontrando o olhar de Opal. Por cima de seu ombro direito, ela percorre indiscretamente todos os rostos que estão no fundo, com um sorriso cínico e patético, como se descobrisse o ridículo de sua situação. Em suave movimento de zoom-in para a esquerda, a câmera abandona Martha e vai achar o rosto absorto de Linnea, completamente alheia ao que se passa no entorno. Seu olhar está fixo na performance de Tom:

"E quando seus olhos jogam luz sobre os meus,

É o que basta pra me convencer.

Me faz abandonar minha fala e comportamento cautelosos..

É por isso que estou sossegado, sim, estou sossegado.

É só dizer que me quer e vou correndo ao seu encontro,

Sem parar pra pensar, porque estou sossegado. ${ }^{, 246}$

Contracampo: close-ups alternados, de Tom e de Linnea. Com a cabeça encostada na parede e olhar completamente rendido, ela respira profundamente, boca entreaberta e olhos semicerrados, como se

\footnotetext{
246 'It's not my way to love you just when no-one's looking./ It's not my way to take your hand if I'm not sure./ It's not my way to let you see what's going on inside of me,/ when it's a love you won't be needing, you're not free./ Please stop pulling at my sleeve if you're just playing,/ if you won't take the things you make me want to give./ I never cared too much for games/ and this one's driving me insane./ You're not half as free to wander as you claim./ But I'm easy, yeah, I'm easy./ Give the word, l'll play your game,/ as though that's how it ought to be,/ because I'm easy./ Don't lead me on, if there's nowhere for you to take me,/ if loving you will have to be a some time thing./ I can't put bars on my inside,/ my love is something I can't hide./ It still hurts when I recall the times I tried./ But I'm easy, yeah, I'm easy./ Take my hand and pull me down,/ I won't put up any fight, because l'm easy./ Don't do me favours,/ let me watch you from the distance,/ because when you're near, I find it hard to keep my head./ And your eyes throw light at mine,/ it's enough to change my mind./ Makes me leave my cautious words and ways behind./ That's why l'm easy, yeah I'm easy./ Say you want me,/ l'll come running,/ without taking time to think,/ because I'm easy, yeah, l'm easy."
} 
sorvesse, extasiada, as últimas palavras do estribilho que Tom repete, antes de ser ovacionado.

Das canções compostas por Keith Carradine para Tom, duas antecedem a produção de Nashville: "It Don't Worry Me", tocada no fechamento da sequência do engarrafamento na autoestrada e pedida pelo público do Exit Inn, e "I'm Easy", esta última com uma letra cujo sentido confessional é admitido pelo ator, que se valera de sua poesia para seduzir Shelley Plimpton, sua colega de elenco nas apresentações teatrais de Hair. Tocadas por Carradine durante uma festa em meio às filmagens de Renegados Até a Última Rajada (Thieves Like Us, 1974), as duas canções deixaram Altman impressionado:

"No momento em que as escutei, eu sabia que faria um filme ao redor delas, um filme que simplesmente me daria uma desculpa para inserir as duas canções', disse o diretor. Se você inspecionar as primeiras versões do roteiro de Joan Tewkesbury, verá que 'It Don't Worry Me' e 'I'm Easy' eram as únicas canções 'originais' incluídas. Em um certo sentido, o roteiro havia sido construído ao redor destas duas canções, que apareciam junto com um cardápio de sucessos country como 'Okie from Muskogee' e 'D-I-V-O-R-C-E'. Mas Altman logo abandonaria a ideia de utilizar músicas conhecidas em favor de uma partitura completamente original, da qual as contribuições de Carradine e Ronee Blakley seriam os momentos musicalmente mais possantes. E se a confiança do diretor precisava de uma confirmação, 'I'm Easy' viria a conquistar para Nashville o seu único Oscar"247.

De fato, Altman tinha consciência do potencial econômico da canção, mesmo antes de a Academia reconhecê-lo com o famoso prêmio, e já o havia utilizado como uma estratégia de convencimento no período de pré-produção de Nashville:

"Convidando [Martin] Starger e [Jerry] Weintraub [respectivamente, presidente de programação da rede $A B C$ e produtor cinematográfico] para sua casa de praia em Malibu, Altman mostrou Carradine cantando 'I'm Easy' e 'It Don't Worry Me' em uma fita cassete. Os dois produtores ficaram cativados." 248

247 STUART, Jan. The Nashville Chronicles. p. 37.

${ }^{248}$ Ibid., p. 43. 
Em outras palavras, mesmo antes de sua ressignificação pelo discurso fílmico, "I'm Easy" é marcada por uma relação ambígua de suas qualidades materiais, responsáveis por seu "efeito de beleza", com o fato de circular como mercadoria. Construída "ao redor" da performance de Keith Carradine, a cena no Exit Inn desdobra esta ambiguidade na forma de uma contradição entre o conteúdo manifesto da letra e a montagem em campo e contracampo, por meio da qual a narração realiza a crítica da estética adotada pelo cantor em seu jogo de sedução.

Num quadro de relações de produção cultural em que as características sensíveis da obra artística são transformadas em atrativos de uma mercadoria que só é comprada na medida em que seu produtor também esteja à venda, Tom precisa esforçar-se por parecer belo e cobiçável. De fato, todas as mulheres enfocadas na cena em algum momento o nomearam como um objeto do desejo: "Ele é tão atraente", diz Opal, como justificativa por tê-lo conhecido "no sentido bíblico"; "Só um momento, mas este cara é um rock star", se desculpa Martha com o tio, antes de correr atrás de um autógrafo do cantor, no saguão do aeroporto; "Eu te amo, eu te amo, eu te amo", confessa Mary, deitada sobre o corpo adormecido de Tom; "Eu te amo" é a mesma frase que Linnea the ensina, em linguagem de sinais, no prosseguimento do quadro presente. Esse deslocamento da "promessa de felicidade"249 contida na forma sensível da obra de arte em uma promessa de satisfação ilusória do desejo, por meio de uma relação libidinal com a imagem do artista e do consumo dos produtos de seu trabalho, é o traço inconfundível da "beleza a serviço da venda" a que Wolfgang Fritz Haug chamou de "estética da mercadoria".

Assim como a mercadoria, para ser comprada, se faz bela, deslocando uma miragem de seu valor de uso na embalagem e na

${ }^{249}$ O conceito de uma "promessa de felicidade" contida na forma das obras de arte é central na teoria estética adorniana. Porém, como lembra James G. Finlayson, Adorno não menciona que a frase de Stendhal de onde retirou a expressão, o romancista francês filosofava "sobre a beleza física, e não sobre a arte, e que essa beleza promete também a felicidade sexual: 'La beauté n'est que la promesse du bonheur."' FINLAYSON, James G. The Artwork and the Promesse du Bonheur in Adorno. nota ํㅡ 2. 
publicidade, o "eu-lírico" exterioriza suas capacidades de "realizador" de desejos, nas imagens poéticas da canção: "Pegue minha mão e me abata; não vou resistir, porque estou sossegado", diz, em tom de promessa. Tornado visível sobre seu corpo na letra ("Não posso pôr grades no meu interior, meu amor é algo que não sei esconder"), o sentimento expresso em imagem pode ser fruído como o "aperitivo" de um prazer físico que, para a maioria das espectadoras, não acontecerá. A linguagem do ritual de sedução é composta de clichês do "galanteio amoroso" (jogos, incertezas, sentimentos, promessas), mas a troca libidinal que transforma o olhar em órgão de prazer e propõe o gozo da imagem como um substituto para a satisfação real ("Quando seus olhos jogam luz sobre os meus, é o que basta pra me convencer") é um desdobramento do fetichismo das mercadorias em uma sociedade do espetáculo. Indiretamente, a crítica de Haug aponta para esta complementaridade entre os clichês da música sentimental e a forma de atuação da mercadoria, da qual o cantor retira uma "expressão estética":

'Quando Marx afirma que 'a mercadoria ama o dinheiro', ao qual ela 'acena' com seu preço lançando 'olhares amorosos', a metáfora dirige-se [...] para uma base sócio-histórica. Pois um gênero de estímulo forte com o qual a produção de mercadorias opera, objetivando a valorização, é o estímulo amoroso. Por conseguinte, um gênero inteiro de mercadorias lança olhares amorosos aos compradores imitando e oferecendo nada mais que os mesmos olhares amorosos, com os quais os compradores tentam cortejar os seus objetos humanos do desejo. Quem busca o amor faz-se bonito e amável. [...]. Do mesmo modo, as mercadorias retiram a sua linguagem estética do galanteio amoroso entre os seres humanos. A relação então se inverte, e as pessoas retiram a sua expressão estética das mercadorias. Ou seja, ocorre aqui uma primeira reação conjunta da forma de uso das mercadorias motivada pela valorização sobre a sensualidade humana. A possibilidade de expressão de sua estrutura impulsiva não só se modifica, como também a sua ênfase se desloca: um forte estímulo estético, o valor de troca e a libido amoldam-se [...]."250

O amoldamento do desejo das espectadoras de Tom às necessidades de valorização mercantil de seu corpo e de sua música é um processo contraditório, cuja expressão adequada em meio fílmico requer a

${ }^{250}$ HAUG, Wolfgang F. Crítica da Estética da Mercadoria. p. 30. 
elaboração de formas dialéticas. Surpreendentemente, o recurso técnico utilizado por Altman para desenvolver o antagonismo entre o ponto de vista de Tom e o de suas consumidoras foi a montagem de planos próximos em campo e contracampo, uma técnica narrativa que, na história do cinema norte-americano, serviu justamente para desbastar contradições entre pontos de vista, produzindo identificação entre espectador e personagens e dando uma sobrevida nas telas a um tipo de diálogo dramático há muito desacreditado pelas práticas do teatro épico. Nas mãos de Altman, esse uso conservador é modificado: em vez de alternar entre tomadas subjetivas de duas personagens em cena dialogada, Altman, que já a utilizara a técnica no Opry Belle para figurar espelhamentos entre Barbara Jean e a plateia, agora justapõe planos do rosto de Tom e os de várias mulheres no centro e nas bordas do enquadramento. A assimetria da alternância - de um lado o cantor sozinho, do outro, o público feminino em geral - não força o espectador a uma identificação com um dos lados do jogo entre planos, preservando o seu distanciamento crítico em relação à cena. Além disso, na medida em que a resposta à dedicatória ambígua é desdobrada pela narração não em um, mas em vários "contracampos", o foco narrativo que se deduz da montagem entre planos é irônico, opondo a intenção do personagem, que proclama uma relação intersubjetiva, à do "narrador", que a desmente como relação da mercadoria com a generalidade do mercado. Em suma, recuperada artisticamente, a técnica é refuncionalizada e posta a serviço da criação de efeitos de distanciamento e ironia, que permitem expandir as contradições embrionárias na canção e na performance do cantor "e assim encontrar na justaposição dos planos o estabelecimento de um elemento qualitativo novo, uma nova imagem, um novo conceito."251

$\mathrm{Na}$ montagem ritmada de Altman, o amor romântico (exclusivo) prometido na letra da canção é desmascarado como uma relação sexual promíscua, mediada por imagens. Iniciando com cortes mais lentos entre o rosto de Tom e as várias espectadoras que se sentem homenageadas pela

${ }^{251}$ EISENSTEIN, Sergei. A Forma do Filme. p. 212. 
canção, o ritmo da alternância de campos se acelera, sugerindo, no jogo entre homem e mulheres, um coito imaginário crescentemente mais tenso, arrancando suspiros de algumas e terminando com a imagem do corpo hirto de Linnea, completamente extasiada. As quatro mulheres enfocadas já haviam sido apresentadas como sexualmente infelizes: a solidão de Opal vagando pelo ferrovelho e pelo estacionamento de ônibus; o casamento insosso de Linnea e Del; o casamento abalado de Mary e Bill; a voracidade sexual de Martha. Colocandose no palco, próximo e distante delas, o cantor oferece seu rosto e sua canção como espelhamentos para a satisfação, sem contato corporal ("Deixe-me olhá-la à distância"), do desejo reprimido de cada uma.

A força desse olhar medúsico, que adivinha o desejo para encarcerá-lo em uma relação de consumo visual, é comprovada na imagem do corpo petrificado de Linnea. Na letra da canção, ela é ainda afirmada ("Você não é livre", "Você não tem metade da liberdade que diz ter") ou falsamente invertida, como a aceitação de um "doce cativeiro do amor" pelo "eu-lírico": "Não posso pôr grades no meu interior", "Me abata, não vou resistir", "Me faz abandonar minha fala e comportamento cautelosos". Na montagem, entretanto, a narração irônica a expõe como puro e simples enclausuramento do desejo na estrutura de recepção da música "enlatada", criando imagens de confinamento ao representar o ambiente claustrofóbico e sufocante do clube lotado, por meio de planos escuros, excessivamente próximos e "indiscretos", povoados por cabeças e outros tantos fragmentos nas bordas do enquadramento. Ao final, apenas Linnea "gozou"; para as outras três participantes, só resta a consciência envergonhada de terem sido vítimas de um engodo e da necessidade de reconduzir à intimidade o "segredo que a mercadoria espalhou". As quatro, indistintamente, caíram na armadilha anunciada por Tom ao trocar o nome do Exit Inn para "Sem saída" ("No Exit"); porém, a montagem dialética de Altman não se contentou em registrar o desnudamento de seu desejo, expondo também - "cantor mercadoria" e os segredos da indústria cultural que o produz, revelando que ambos não cessam 
"de lograr seus consumidores quanto àquilo que [estão] continuamente a lhes prometer. A promissória sobre o prazer, emitida pelo enredo e pela encenação, é prorrogada indefinidamente: maldosamente, a promessa a que afinal se reduz o espetáculo significa que jamais chegaremos à coisa mesma, que o convidado deve se contentar com a leitura do cardápio. Ao desejo, excitado por nomes e imagens cheios de brilho, o que enfim se serve é o simples encômio do quotidiano cinzento ao qual ele queria escapar. De seu lado, as obras de arte tampouco consistiam em exibições sexuais. Todavia, apresentando a renúncia como algo de negativo, elas revogavam por assim dizer a humilhação da pulsão e salvavam aquilo a que se renunciara como algo mediatizado. Eis aí o segredo da sublimação estética: apresentar a satisfação como uma promessa rompida. A indústria cultural não sublima, mas reprime. Expondo repetidamente o objeto do desejo, o busto no suéter e o torso nu do herói esportivo, ela apenas excita o prazer preliminar não sublimado que o hábito da renúncia há muito mutilou e reduziu ao masoquismo. [...]. As obras de arte são ascéticas e sem pudor, a indústria cultural é pornográfica e puritana."252

Uma nova coincidência entre os aplausos de Tom e os de Sueleen, na sequência paralela cuja progressão temporal estivera suspensa, reforça a coesão formal entre as duas cenas; a música burlesca, típica dos shows de strip-tease, que tenta adiantar o número de Sueleen, é exibida sobre a imagem de Linnea ainda extasiada com a performance de Tom, exigindo que o espectador faça uma ligação intelectual entre os dois tipos de espetáculo, mediada pela referência à pornografia. Uma constelação temática, surgida da reiteração de gestos e imagens, vai-se formando: na exclusividade do smoker para financiadores de campanha, na decepção da plateia que pagou pelo show de Barbara Jean, mas não o recebeu, e na exposição da intimidade das mulheres forçadas a participar da troca libidinal entre Tom e Linnea, a narração vai pontuando os custos econômicos e os compromissos subjetivos envolvidos em relações mediadas pela forma-mercadoria. Na volta ao smoker, o espectador contempla, mais uma vez, o funcionamento da relação fetichizada; a novidade é que ela agora é mostrada como uma forma de coação. Da montagem paralela das duas sequências, emerge uma avaliação: consentido ou

${ }^{252}$ ADORNO, Theodor W. \& HORKHEIMER, Max. Dialética do Esclarecimento. p. 130 - 131. 
coagido, o "coito visual com a mercadoria" é sempre um ato de violência, contra a plateia, num caso, contra a cantora amadora, no outro.

Sueleen agradece pelos aplausos. O rosto de Del está vermelho de excitação; já o de Triplette tem uma expressão desconfiada e incerta. Assomando-se na fenda da cortina vermelha, o rosto de Albuquerque cria um ponto de referência interno para o olhar do espectador. Assim como ela, nós também vamos espiar uma cena para a qual não fomos convidados. "Vou cantar uma música composta por Barbara Jean, mas antes quero ficar mais à vontade", diz Sueleen, retirando o capuz caído sobre os ombros. Fora do campo, uma voz comemora excitadamente. O piano começa a introduzir a canção, a plateia aplaude e Sueleen anuncia: "Chama-se "One, I Love You". No extracampo, uma voz exulta: "Você acertou em cheio, neném." No primeiro plano, próximo do enquadramento da imagem, um homem ri sonoramente.

O desempenho de Sueleen com a canção famosa é ainda pior do que a performance demonstrada com a canção de sua própria autoria e a banda precisa reduzir o tempo para conseguir acompanhá-la. Impaciente, a plateia não deixa a cantora chegar à segunda estrofe, vaiando, gesticulando e tentando pará-la com aplausos. Desta vez, a câmera nos distanciou do ponto de vista dos espectadores internos, mostrando-nos, em planos médios frontais, a expressão assanhada dos vários homens "respeitáveis" de Nashville. Alguém grita "Isso é algum tipo de trapaça de Walker?", enquanto outro ordena: "Vai, tira logo". Amassadas em pequenas bolinhas, as "promissórias" (pledge cards) que estavam sobre as mesas são atiradas como dardos contra Sueleen; Bud tenta arremessar uma nota de dólar cujo "voo" para no meio do caminho. Num canto, Del e Triplette confabulam:

Del: Você falou para o Trout ["empresário" de Sueleen] o que você queria?

Triplette: Eu? Falar para o Trout? Isso era trabalho seu, Del. Eu presumi que ele sabia que... 
Del: Eu sei, mas...Bom, eu achei que não teria problema.

A voz de Sueleen vai ficando fraca, piorando conforme tenta segurar o choro, enquanto é atacada com papéis, dinheiro, vaias e aplausos impacientes. "Tira a roupa!" Assustada com a ira crescente da plateia, ela interrompe a canção, deixa o microfone sobre o piano e sai do palco, com expressão derrotada. Uma voz no extracampo ainda diz, insolente, "Vamos ver uma teta!", enquanto outras reclamações se sobressaem às vaias: "O que é que é isso?", "Volta aqui, neném!" As palmas agora são ritmadas e sincronizadas, tentando forçar seu retorno. Ao aproximar-se da cortina no fundo do clube, a cantora é interceptada por Triplette e Del, que impede sua passagem, apoiando uma mão sobre seu ombro e segurando-a pelo braço com a outra. Sueleen chora e traz uma expressão confusa no rosto.

Del: O que aconteceu, docinho?

Sueleen: Não estou entendendo o que está acontecendo.

Del: (com expressão cínica) O Trout não te contou que você teria que tirar a roupa?

Sueleen: (indignada) Eu sou cantora!

Triplette: (preocupado com a tensão da plateia enraivada, avalia a situação) Escuta, escuta, escuta. Volta lá e termina seu show, do jeito que o Trout falou, e eu arranjo para você cantar no Parthenon. Eu vou dar um jeito de você cantar no Parthenon com Barbara Jean. Agora volta lá e termina seu show.

Sueleen: (indecisa) E eu canto no Parthenon com Barbara Jean?

Triplette: Sim, claro. Eu tomo conta de tudo pra você. Agora volta lá e termina o show do jeito que o Trout falou. Tudo bem?

Del: (encorajando-a) Esses caras aí te adoram. (Palmas e gritos no extracampo). 
Sueleen: (repentinamente infantilizada, fala como uma criança que acabou de receber um agrado em troca de algo que não queria fazer e tenta estender o alcance do presente) E um dia eu vou ser uma estrela tão grande quanto Barbara Jean?

Triplette: (entrando no jogo de Sueleen, fala com voz paternal, confiante) Eu sei que você vai; não tem como errar. Agora, vai lá!

Sueleen desce à arena, onde é recebida com aplausos excitados. Mais uma vez, a banda toda a música de cabaré, disparando em seu corpo uma sequência coreográfica desempenhada de forma mecânica. Passando por trás dos músicos, ela retira uma luva que atira à plateia. Orgulhosamente, um homem de meia idade a exibe como troféu. Em uma sequência rápida, desprovida de qualquer sensualidade, a personagem baixa a parte de cima do vestido, retira dois enchimentos do sutiã e os lança ao público. "Você é minha mamãe!", grita uma voz mais exaltada. A calcinha, último movimento da coreografia, é retirada atrás do pianista, encobrindo a visão do sexo da atriz. Um homem ainda agarra a peça, girando-a no ar, vitoriosamente. De costas para a câmera, Sueleen caminha na direção da cortina, sem olhar para trás e sem agradecer pelos aplausos acalorados que sua fria apresentação suscitou.

Se a prostituição do corpo de Sueleen já estava anunciada na frase utilizada por Del para anunciar o seu número, faltava ainda o elemento simbólico que a identifica: a mediação do dinheiro. Pressuposto em outros diálogos no quadro temático (por exemplo, na oferta que Del faz a Barnett, no Opry Belle, no galanteio de Wade a Linnea, oferecendo pagar sua conta, na rejeição de Opal a conversas com "serviçais"), referido nas reminiscências de Barbara Jean (os cinquenta centavos pagos pela memorização do jingle comercial) e na canção de Sueleen ("Não preciso que estufem meus bolsos com notas de cem"), o dinheiro ainda não havia aparecido em uma forma tão violenta e ostensiva quanto a nota de dólar e as bolinhas de papel feitas com as "promissórias" (pledge cards), arremessadas contra a 
amadora no palco, impedindo seu trabalho e forçando-a a tirar a roupa. Por meio do elemento visual, o ponto de vista narrativo traz à cena o fundamento histórico da prostituição moderna:

"[...] experimentamos na natureza do [...] dinheiro alguma coisa da essência da prostituição. A indiferença em relação ao seu uso, a falta de comprometimento em relação a quaisquer indivíduos por não estar atrelado a nenhum deles, a objetividade inerente ao dinheiro enquanto simples meio que exclui toda e qualquer relação emocional - tudo isso produz uma analogia sinistra entre o dinheiro e a prostituição. O imperativo moral de Kant, segundo o qual não se devem tratar seres humanos como meios, mas aceitá-los e tratá-los sempre e ao mesmo tempo como fins em si mesmos, é ostensivamente ignorado, por ambas as partes, no caso da prostituição. De todas as relações humanas, a prostituição é talvez o exemplo mais impressionante de rebaixamento mútuo à mera condição de meios e este deve ser o fator mais fundamental a colocar a prostituição numa relação histórica tão próxima com a economia monetária, a economia 'dos meios' no sentido estrito."253

As afirmações de Simmel ajudam a compreender como a mediação da forma monetária expõe a própria dialética da prostituição na cena, contaminando todo o conjunto. Na presença fulgurante do dinheiro, os mascaramentos vão-se desfazendo e a cantora não se faz prostituta sozinha; acompanham-na os demais elementos cênicos, mudando de feição como numa "reação química": a banda tocando a música burlesca perde a roupagem da arte, sendo exposta como fundo musical para um ato de violência; os empresários e o mestre de cerimônias, Trout, Del, Triplette e o próprio Walker, são desmascarados como facilitadores e beneficiários de prostituição; a plateia, até então protegida nas bordas escuras do enquadramento, é despida pela câmera por meio de planos próximos e frontais, que revelam toda a sanha de rostos transtornados de impacientes consumidores do corpo prostituído. Na presença do dinheiro, a relação estética sofre uma transubstanciação e a imagem estigmatizada do artista como um "prestador de serviços a quem pode pagar" aproxima-se da realidade material ${ }^{254}$.

\footnotetext{
${ }^{253}$ SIMMEL, Georg. The Philosophy of Money. p. $376-377$.

254 "O campo da performance musical sempre sofreu o estigma social de serviço para aqueles que podem pagar. Historicamente, a prática da música sempre esteve ligada à venda do talento
} 
E o espectador do filme? Seria o caso de perguntar se também somos alterados pela combinação entre dinheiro e nudez, transformando-nos em voyeurs involuntários de uma cena pornográfica. A narração não parece seguir neste caminho, protegendo nosso distanciamento emocional dos problemas encenados justamente por meio de um artifício de identificação: a oferta de um ponto de vista interno como um espelhamento de nosso olhar sobre a cena. Até então, o rosto de Albuquerque, espiando através da fenda da cortina vermelha, só havia sido notado pelo "olhar da câmera"; porém, no momento em que as tensões vão aumentando e ameaçam tragar o espectador para dentro da relação fetichista, a imagem de Albuquerque mulher, pobre e também aspirante a uma carreira musical - deve ajudar-nos a preservar uma certa distância dos demais espectadores internos. Albuquerque não fica excitada e nem pode influir no strip-tease de Sueleen, mas, para sua própria vantagem futura (é ela, e não Sueleen, quem canta no Parthenon), deve tirar lições do que vê; ao colocar-nos de frente para ela, a narração sugere que procedamos de modo análogo, compensando nossa impossibilidade de intervir na cena com uma participação intelectual mais ativa.

Além disso, na medida em que a narração enfatiza o sentido de classe da violência contra Sueleen, a adesão momentânea ao ponto de vista de Albuquerque significa também um posicionamento político do espectador em relação à cena. Evidentemente, como em outros momentos do filme, este posicionamento não é uma imposição e o narrador se limita a sugerir pontos de vista mais abrangentes; a decisão é do espectador, de quem se exige apenas a capacidade de justificar suas escolhas. Pois, se a prostituição, como argumenta Simmel, é uma forma de "rebaixamento mútuo", o strip-tease de

individual ou, até mesmo, da individualidade, diretamente, sem intermediários, em vez da venda do trabalho na sua forma congelada, ou seja, como uma mercadoria; e durante eras, o músico, assim como o ator, tem sido encarado como um parente do lacaio, do bobo da corte e da prostituta. Embora a performance musical pressuponha trabalho, e do tipo mais especializado, 0 fato de que o artista apareça em pessoa e de que haja uma coincidência entre sua existência pessoal e aquilo que ele realiza cria a ilusão de que ele faz música por diversão, de que ele ganha dinheiro sem um trabalho honesto." ADORNO, Theodor W. \& EISLER, Hanns. Composing for the Films. p. 31 
Sueleen deve dizer muito sobre a personagem, mas expor ainda mais os seus aliciadores, a sua plateia, o tipo de narração utilizado para representá-lo e, no limite, o significado de classe das emoções que o espectador de cinema experimenta ao assisti-lo.

Ao tentar fugir da arena, Sueleen é interceptada por Del; segurando-a pelo braço, o personagem reitera um gesto que já havia feito antes, no Opry Belle, ao pressionar os ombros de Barnett, tentando coagi-lo a abandonar seus princípios políticos e aceitar que Barbara Jean participe do comício. Naquele momento, ele arrematara o gesto com uma frase: "Vou ficar na cola desse cara como um roedor". O mesmo gesto é recuperado por Barnett, no final do colapso de Barbara Jean, segurando-a pela cintura e the tomando o microfone. Nos três fragmentos de cena, a mensagem comunicada pelo movimento corporal é a mesma: é inútil tentar resistir a um poder econômicosexual capaz de esmagar qualquer resistência. No caso de Sueleen, essa imagem de inexorabilidade do poder traz um elemento novo: a perversidade do ato de prostituição cuja vítima não tem plena consciência do que está fazendo. "Não estou entendendo o que está acontecendo aqui", diz Sueleen. Del se defende: "O Trout não te contou que você teria que tirar a roupa?" Sueleen não afirma nem nega; apenas trata de marcar uma diferença qualitativa entre música e prostituição ("Eu sou cantora!"), do mesmo modo que Barnett, na cena anterior, tentara separar a arte de Barbara Jean de uma possível adesão ao programa de Walker. De fato, na cena em que Sueleen é contratada, Trout não Ihe fala de strip-tease, mas a oferta de Triplette ("Volta lá e termina seu show, do jeito que o Trout falou, e eu arranjo para você cantar no Parthenon") sugere que muitos acontecimentos da história foram elididos pelo discurso narrativo. De qualquer forma, essa incerteza quanto ao grau de consciência da personagem sobre a armadilha em que estava pisando dá à cena uma ambiguidade que só faz enriquecer a exposição: se ela nada sabia e foi enganada por todos, então a perversidade de seus contratadores beira a ação criminosa; se ela desconfiava, ou sabia, e ainda assim tentou satisfazer a plateia apenas com seu canto "ruim", 
ficam sublinhados os riscos a que o trabalho cultural é exposto por não contar com os meios necessários à sua realização.

Algumas modificações de última hora, propostas pelo elenco, contribuíram para a criação dessa ambiguidade. "Tal como constava no roteiro de Joan Tewkesbury, a consciência de Sueleen sobre a verdadeira natureza de seu trabalho viria em etapas" ${ }^{255}$. Numa cena que não chegou a ser filmada, Triplette pediria para ver o figurino a ser usado no show e Sueleen, suspeitando de suas intenções, começaria a cantar, forçando-o a mudar de assunto. Apelando para o sentimento católico da personagem, Triplette diria que o objetivo do strip-tease era levantar fundos para caridade. "No restante da cena ideada por Tewkesbury, Sueleen é recebida com entusiasmo depois do primeiro número e tenta escapar do strip-tease sugerindo uma segunda canção"256. Entretanto, Ned Beatty (Del) não estava satisfeito com essa sequência de ações, pois acreditava que ela diminuía a responsabilidade de seu personagem nos problemas expostos. Falando com Altman na noite anterior à filmagem da cena, 0 ator conseguiu melhorar o roteiro. Joan Tewkesbury recorda a conversa que teve com o diretor depois de ouvir os argumentos de Ned Beatty:

"Eu disse a Bob [Altman]: 'se deixarmos como está, Ned e todo mundo escapa da responsabilidade. A questão de fundo é que, nesta cena, todos estão em conluio. Sueleen é muito mais complexa do que isso. Ela ouviu que deveria tirar a roupa, mas preferiu não prestar atenção. No que the diz respeito, trata-se apenas de uma performance musical. Do contrário, Sueleen se transforma em uma personagem clichê. O personagem de Ned também se transformará em um clichê se não houver essa outra complexidade, trazida pela cumplicidade na ambição."’257

Não fica totalmente claro na cena se essa cumplicidade é anterior ao strip-tease ou se ela é inteiramente forjada ali, no calor do momento. De qualquer forma, a narração sublinha, por meio de uma série de contradições, a profunda assimetria das partes em conluio. De um lado,

${ }^{255}$ STUART, Jan. The Nashville Chronicles. p. 244.

${ }^{256}$ Ibid., p. 245.

257 Ibid., p. 246. 
está a moça jovem, solitária, exibindo-se numa situação que considera a primeira etapa de seu caminho rumo ao estrelato; do outro, está um grupo de homens, a maioria dos quais com idade para ser seu pai, que pagaram para vêla despida. A concorrência de elementos simbólicos e explícitos (a violência contra o corpo feminino pelo poder opressivo do dinheiro nas mãos de figuras paternais) dá ao strip-tease uma conotação de "estupro incestuoso", jogando sobre seus dois aliciadores a sombra "diabólica" do "pai sedutor", que em vez de barrar o caminho que leva ao "incesto", tenta justamente desviar a jovem infantilizada naquela direção. Como lembra Renato Mezan,

"A ideia da sedução envolve uma dupla representação; primeiro, a do desvio, do aliciamento, do meandro; e uma outra, requerida pela primeira, de uma linha reta e pura, anterior à perversão sedutora. [...]. É igualmente pressuposta a figura de um agente, seja a serpente ou o lobo mau, por cujo intermédio se verifica o desvio - agente que opera pela promessa de falsos brilhantes, pela mentira, pelo simulacro, enfim, fazendo apelo ao narcisismo do ente a ser seduzido a fim de melhor agarrá-lo nas redes da lisonja. A sedução é assim imaginada no registro da simulação, e as consequências da ingenuidade [...] desfazem o percurso da aparência para mostrar em sua crueza a verdadeira face do sedutor"258

No caso de Sueleen, o mecanismo da sedução que leva ao "incesto" se torna mais complexo na medida em que não se pode falar, com certeza, de uma ingenuidade perdida ou de um "bom caminho" de que ela foi desviada. Entretanto, os outros elementos da sedução perversa estão presentes. Del é o primeiro a funcionar como "tentador"; mas a lisonja pouco refinada ("Esses caras aí te adoram") não é tão efetiva quanto a estratégia de Triplette. Caracterizado como um "dissimulado" desde a primeira conversa com Del no engarrafamento, Triplette é proficiente na linguagem estética da mercadoria; na condição de marqueteiro político, sabe, como ninguém, adivinhar desejos escondidos e devolvê-los, como objetos à venda, ao sujeito desejante. Lendo no rosto da amadora que nada poderia ser mais cobiçável do que uma participação no comício ao lado das maiores estrelas de Nashville, o organizador do evento Ihe acena com uma oferta de trabalho. Diante do "falso brilhante", os

${ }^{258}$ MEZAN, Renato. Freud, pensador da cultura. p. $208-209$. 
olhos da personagem, efetivamente, brilham. O sedutor pode então indicar 0 preço: voltar ao palco e tirar a roupa. A personagem embarca ainda numa espécie de delírio infantil, buscando da figura "paterna" uma confirmação de que um desvio momentâneo no seu caminho não impedirá que ela atinja seu objetivo último: "E um dia eu vou ser uma estrela tão grande quanto Barbara Jean?" É a deixa para que Triplette "acaricie" seu narcisismo ("Eu sei que você vai; não tem como errar"), determinando que seu primeiro passo no mundo do show business "respeitável" seja também o último.

Em outras palavras, quando aceita voltar à arena, Sueleen troca, inadvertidamente, a possibilidade futura de atuar como Barbara Jean pela realização ilusória do "desejo de trabalhar" a seu lado. A perversidade da troca é evidente: o direito ao trabalho é transformado em mercadoria para convencer o trabalhador a aceitar sua prostituição e esta se torna a ação que o impedirá de ter um acesso duradouro ao trabalho. Duas ações antagônicas e complementares dão forma gestual a um desnudamento que é também simbólico: de um lado, o gesto de despir violentamente alguém por meio de vaias e aplausos agressivos; do outro, o gesto de despir-se para alguém em troca de uma oportunidade de trabalho. O foco narrativo assume atitudes diferenciadas em relação aos aspectos contraditórios desse gesto: a algazarra da plateia, que tenta arrancar as proteções da cantora, é observada em planos próximos e captada por uma trilha sonora que deixa ouvir frases comprometedoras como "Vai, tira logo" e "Você é minha mamãe"; já a visão do corpo nu da atriz é parcialmente obstruída por algum tipo de obstáculo interno (a pilastra, a banda, vultos), impedindo que suas partes mais íntimas sejam expostas para o espectador de cinema. Em outras palavras, embora a narração dê um tratamento irônico à ignorância da personagem a respeito da própria incapacidade de cantar, sublinhando o efeito ridículo, contrário à intenção, que dela resulta, no momento em que um conflito de interesses se apresenta, o "olhar narrador" coloca-se do lado mais fraco, esforçando-se por resguardá-lo. 
Portanto, o gesto de despir lança conotações amplas sobre os acontecimentos narrados, para além das cenas adjacentes no quadro temático. "Para Joan Tewkesbury, o smoker é simplesmente o centro moral do filme. 'É a sua chave, a sua metáfora: se você quiser chegar lá, em algum momento você vai ter que tirar a roupa"”259. De fato, essa regra se comprova na trajetória de todos os cantores que, após sustentarem algum tipo de resistência aos avanços do empresário de Walker, acabaram por ceder e aparecem enfileirados no palco do Parthenon, na sequência final. Deste modo, sugere-se que a prostituição da força de trabalho não depende da vontade e é generalizada, embora só em Sueleen a sua violência subjacente ganhe uma forma ostensiva. Portanto, quando a canção burlesca dispara na personagem uma coreografia não ensaiada e, no entanto, tecnicamente executada, como se Sueleen estivesse "morta, do mesmo jeito que se faz quando se separa a cabeça do corpo" ${ }^{\text {"260 }}$, ela sintetiza a precariedade da posição de todas as outras personagens e oferece uma imagem da desfiguração e do esvaziamento sofridos pelo trabalhador cultural privado de seus meios e forçado a executar operações degradantes, contrárias a seus objetivos e desejos ${ }^{261}$. Ao "proteger" a personagem, a narração toma o partido do trabalhador cultural que ela representa, mas seu olhar empático não se detém na constatação de um problema; apropriando-se dos meios necessários (dramaturgia, montagem, encenação, etc.), o "olhar narrador" salva a crítica, como uma alternativa para o aparente "beco sem saída" em que o trabalho foi preso.

Corte abrupto na imagem, que salta do espaço do smoker para o primeiro plano de um toca-fitas de rolos. A suavidade da canção tocada - "I'm Easy" - contrasta com a energia da música burlesca e as palmas

\footnotetext{
${ }^{259}$ STUART, Jan. The Nashville Chronicles. p. 238.

260 TEWKESBURY, Joan. apud in: STUART, Jan. The Nashville Chronicles. p. 249.

261 Neste sentido, a imagem da "humanidade em Sueleen" reduzida a gestos mecânicos automatizados recupera a força da metáfora utilizada por Marx para descrever as condições de vida do trabalhador apartado dos meios de produção como as de um caracol sobrevivendo fora de sua concha, a mesma metáfora que Ricardo Antunes recupera em sua coletânea de ensaios a respeito das formas degradantes de trabalho na sociedade contemporânea. ANTUNES, Ricardo. O Caracol e sua Concha. p. 20.
} 
no quadro anterior, sugerindo um salto também na trilha sonora. A tomada reitera duas outras, feitas no quarto de Tom, em cenas íntimas com Mary e Opal. A única diferença é que, em vez de "varrer" o espaço em um movimento panorâmico até revelar o dono daquele quarto e daquela música, o foco narrativo corta diretamente, do plano inicial, para a imagem de Tom e Linnea, embaixo de um cobertor, com pouca luz. O torso de Tom está nu e Linnea veste uma espécie de combinação. Tom acende um cigarro na chama de uma vela e logo em seguida o abajur. Linnea puxa conversa:

Linnea: Você quer aprender a dizer uma coisa em linguagem de sinais?

Tom: Quero. Como é que se diz 'eu te amo'?

Linnea: (Faz uma mímica, acompanhada de explicações; Tom copia seus gestos. Linnea espanta a fumaça do cigarro de Tom) Como você consegue fumar essas coisas?

Tom: (Em sincronia com o estribilho de "I'm Easy") "It's easy", é fácil.

Linnea pede para experimentar o cigarro; Tom Ihe dá um beijo na face, em gesto de ternura. Linnea encara Tom nos olhos e logo se dá conta do relógio de pulso sobre o criado-mudo. Apanha-o, verifica as horas e avisa que precisa ir embora. A frase coincide com o silenciamento do toca-fitas; o romance durou o "tempo de uma canção". Contrariado com a recusa de Linnea em ficar mais tempo ao seu lado, Tom apanha o telefone e disca um número. Em frente a um espelho, mas voltada para o cantor, Linnea começa a vestir-se. Com nosso ponto de audição identificado com o personagem, ouvimos a telefonista completar uma discagem à distância, o ruído de telefone tocando do outro lado da linha e, em seguida, uma voz de mulher.

Tom: E aí? (Linnea se vira para o espelho, vestindo um elegante casaco) Como é que você está? Escuta, eu sinto muito por ter te deixado daquele jeito. ( $A$ imagem de Linnea, refletida sobre $o$ espelho, olha lateralmente para Tom). 
Voz feminina: Puxa, como é bom falar com você. (Diante do espelho, Linnea enxuga as mãos e a boca; depois ajeita um lenço no pescoço).

Tom: Estou aqui sentado pensando em você. Escuta, será que você não conseguiria vir até aqui? (Linnea faz menção de responder, virando-se na direção de Tom, mas logo se dá conta de que o convite não se endereçava a ela, voltando-se para o espelho e continuando a sequência de gestos que terminarão por vesti-la).

Voz feminina: Tom, eu não posso fazer isso. Eu tenho uma inauguração no museu e não posso simplesmente largar meu emprego.

Tom: Por que você não sai desse emprego? Eu estou ganhando o suficiente por aqui.

Linnea confere sua aparência no espelho e faz menção de sair, mas logo se lembra de um objeto que faltou ao conjunto: a calcinha, que esqueceu enrolada no pé de Tom. Com o tempo já escasso, agarra o objeto e o enfia na bolsa, apressadamente.

Voz feminina: Sinto sua falta. (De pé, ao lado da cama, Linnea se aproxima de Tom e lhe dá um beijo rápido, de costas para a câmera; Tom cobre, momentaneamente, o transmissor do telefone). Sinto de verdade. Nova lorque também tem sentido sua falta. (Linnea sai do campo e logo reaparece, de costas, abrindo a porta, na imagem refletida no espelho. Vira-se, mais uma vez, na direção de Tom; aponta o indicador para o próprio olho e em seguida na direção de Tom, em sinal de aviso: "Cuidado!" Sai batendo a porta). Que barulho foi esse?

Tom: Nada. Serviço de quarto. (Fingindo falar a alguém): tem cinquenta centavos sobre a mesa; pode pegar.

Voz feminina: (Risadinhas) Grande gorjeta!

Tom: Pois é, tempos difíceis! 
Voz feminina: Com todo esse dinheiro, você não conseguiria me levar até aí.

Tom: (Repentinamente aborrecido) Ah, bem, deixa prá lá. Te vejo em uma semana.

Voz feminina: Eu te amo, Tom.

Sem responder, Tom desliga o telefone, ruidosamente.

Corte para um plano de uma rua mal iluminada e decadente. O Cadillac de Del para ao lado de um lance de escadas que leva à casa de Sueleen. Apressadamente, Sueleen salta do carro e se dirige à porta, seguida de perto por Del:

Del: Ei, espera um minuto. (Segurando Sueleen pelo braço, impede que ela entre em casa). Olha, eu sei que você não faz aquilo o tempo todo e eu... eu... (ofegante) eu queria que você soubesse que eu, quero dizer, da minha parte, rapaz!, eu (aproximando-se mais de Sueleen), você sabe, eu queria beijar você inteira, em todos os lugares. Você entende o que estou querendo dizer? Eu acho você... ( $O$ vulto de Wade, amigo de Sueleen, se assoma ao pé da escada).

Wade: Sueleen? Tudo bem com você?

Del: (Descendo as escadas) Que droga, cara! (De dentro do carro, fora do campo) A sua mãe não te ensinou boas maneiras?

Wade: (Chegado à porta) Quem era aquele sujeito? (Ruído de automóvel dando a partida, fora do campo) O que está acontecendo com você? Você não vai falar comigo? (Pacientemente) Deu tudo certo lá?

Sueleen: (Mortificada) Oh, Wade! Eu fui obrigada a fazer um strip-tease hoje à noite na frente de um monte de homens para poder cantar com Barbara Jean no Parthenon. 
Wade: Mas que m..., Sueleen, eu... (em tom de repreensão) Isto foi muito feio! Foi terrível, garota! Quero dizer... eu não sei como é que eu vou te dizer isso, mas tem uma coisa que eu estou querendo te falar há muito tempo: você não sabe cantar. Sueleen, você tem de encarar o fato de que você não sabe cantar, de que você nunca vai ser estrela coisa nenhuma. Se pelo menos você desistisse agora. ( $A$ expressão de Sueleen modifica-se rapidamente; de mortificada, passa a sarcástica, como se duvidasse do que Wade lhe diz). O que eu quero dizer é que eles vão matar você. Eles vão estraçalhar seu coração se você continuar insistindo. Eles vão pisotear na sua alma, menina!

Sueleen: Não sei do que você está falando.

Wade: (Irritado com a teimosia de Sueleen) Mas você não sabe cantar! Pelo menos isso, você consegue entender?

Sueleen: (Desafiadora) Ah é? Quer fazer uma aposta? Quer ir ao Parthenon me ver cantar com Barbara Jean?

Wade: Escuta, eu estou indo pra Detroit na quarta-feira.

Sueleen: (Abrindo a porta) Pois então vá ao Parthenon e me assista, Wade.

Wade: Escuta, eu estou indo embora pra Detroit e, se você quiser vir comigo, é só me acompanhar. Eles vão te matar nesta cidade, menina.

Sueleen: (Refratária a qualquer repreensão) Bem, vá e veja com seus próprios olhos.

Wade: Eles vão te usar. Você sabe disso.

Sueleen: (Já dentro de casa, apontando o rosto pela porta entreaberta) Tchauzinho, Wade. (Fecha a porta).

Wade: (Descendo as escadas, irritadíssimo) Burra! Não sei por que eu ainda fico do lado dela. Ela me deixa tão irritado que eu começo a cuspir. 
As duas cenas que fecham o quadro temático exibem os desdobramentos imediatos das performances de Tom e Sueleen. Mais uma vez, a ausência de relações de contiguidade ou de outros elementos coesivos proeminentes entre os espaços justapostos dá a falsa impressão de que as ações representadas constituem duas linhas de continuidade independentes. No entanto, uma observação mais detida reconhecerá homologias "transversais" entre as cenas paralelas: ambas figuram o resultado das duas performances como rupturas, respectivamente, de uma relação amorosa podada quando mal começara e de uma amizade de longa data. Além disso, as triangulações afetivas iniciadas no começo do quadro vão-se desdobrando entre uma cena e outra: no Exit Inn, Tom dedicara sua canção a Linnea, mas atingira um terceiro elemento: o público feminino; no smoker, Sueleen repetira a forma da relação, embora não exatamente o seu conteúdo, como o vértice mais fraco de um jogo de forças que ainda tinha a plateia de um lado e Triplette e Del do outro; no quarto de Tom, Linnea, esposa de Del, vê sua relação íntima com Tom ser desdobrada pelo telefonema à mulher em Nova lorque; algo parecido ocorre na porta de Sueleen, quando a declaração "cafajeste" de Del, marido de Linnea, é interrompida por Wade, que surge nas sombras da imagem.

Portanto, o jogo entre as duas cenas é de espelhos e o movimento das personagens desenha trajetórias triangulares, das quais a constituição de Tom é a mais evidente. Há homogeneidades também entre a composição da cena de Tom e Linnea na cama e aquela de duas cenas anteriores, com Opal e Mary, respectivamente. Nas duas primeiras, a narração percorre, em modo essencialmente descritivo, a mesma trajetória de apresentação (gravador, cama, roupa, capa de disco, vasilhas de comida, amantes), sugerindo a banalidade do estabelecimento e do desmanche de relações na vida de Tom. Na terceira cena, parece ocorrer uma síntese: saltando diretamente do plano próximo do toca-fitas de rolos, o foco narrativo ilumina o casal na cama (e Tom repete o gesto acendendo o abajur), sem refazer 0 "inventário de objetos" das cenas anteriores, passando daí, diretamente, à representação de suas ações. Fatos novos ajudam a efetuar a síntese 
compositiva do personagem: a revelação de problemas financeiros ("É, tempos difíceis!") que o impedem de trazer para perto de si a namorada nova-iorquina e o fato de estar ausente de casa, de ser um cantor que, para sobreviver, precisa "pôr o pé na estrada". A partir desses elementos, entende-se que a forma de amar sem apego que caracteriza o personagem não é um indício de defeito moral; bem ao contrário, o que se sugere é a formação de uma "moral eficiente", amoldada pelas e para as necessidades do sistema econômico, pois, para continuar a realizar o movimento que o conserva, o personagem não pode, efetivamente, criar vínculos afetivos com lugares ou com pessoas.

Nesta síntese, o personagem, cuja virilidade parecia incontrastável, é exposto em suas fragilidades. Parte do trabalho de exposição das fraquezas de Tom é efetuada por Linnea que, ao repetir e inverter algumas das ações de suas antecessoras, recupera o autocontrole e anula a sedução do cantor famoso. A primeira destas inversões é o fato de que, diferente de Mary e Opal, Linnea não está nua na cena, mas "semivestida", com uma combinação. A moda antiga sublinha a diferença de idade entre ela e seu amante, assim como a crítica velada ao hábito de fumar ("Como você pode fumar essas coisas?") traça uma linha divisória entre seus respectivos estilos de vida, com uma valorização evidente daquele que ela leva. Se no dia seguinte à noite de amor, Tom praticamente expulsara Opal de sua cama, agora é Linnea quem decide ir embora, comandando o tempo que ela verifica no relógio e marca nos seus gestos, vestindo-se, em vez de despir-se, para depois ir embora, a despeito dos pedidos infantis do amante. A calcinha recuperada e rapidamente guardada na bolsa é um elemento simbólico importante, pois, lembremos, na cena imediatamente anterior, Sueleen atirara a mesma peça de vestuário à plateia voraz. Finalmente, a figuração mais clara de que Linnea inverteu o sentido da relação de dominação sexual é a breve aula de linguagem de sinais por meio do qual ela passa a exercer, ainda que docemente, a autoridade de professora sobre o star da música, nivelando-o com os próprios filhos a quem ela já ensinara a "cantar" na mímica das mãos. Porém, o símbolo patente de castração na cena é o fato de que a personagem devolve a frase-clichê ("Eu te amo"), 
lançada para tentar impedi-la de ir embora, em uma aula de expressão gestual que sugere ao cantor uma suspensão de sua voz, cortando assim o canal com que ele a seduzira do Exit Inn para seu quarto.

Portanto, é preciso cuidado na hora de categorizar a grosseria de Tom, que telefona à namorada de Nova lorque na presença de Linnea. Aparentemente, a intenção é a de causar ciúme e demover Linnea da decisão de ir embora. O método utilizado é aquele em que o personagem se sente à vontade: adivinhar o desejo alheio e manipulá-lo por meio de simulacros. Aqui, a montagem da cena é rigorosamente precisa, sublinhando a tensão entre a encenação proposta por Tom ao telefone e as reações de Linnea, por meio de sincronizações entre som e imagem: quando o personagem diz "It's easy", a sua fala coincide com o estribilho da música de que ele se vale para seduzir; contrariado pela decisão de Linnea, ele the faz uma censura indireta, desculpando-se com a interlocutora no telefone por ter saído repentinamente no seu último encontro; quando a voz no receptor diz "sinto sua falta", é Tom quem recebe uma última prenda de Linnea, um beijo quase maternal para compensar a falta que ela lhe fará. Durante a conversa telefônica, a imagem de Linnea refletida no espelho permanece invariavelmente distante, lançando apenas um ou outro olhar ocasional na direção de Tom. Antes de sair, ela ainda gesticula um aviso para o cantor tomar cuidado, a tempo de escapar da simulação "cafajeste" da gorjeta sobre a mesa, uma última tentativa de macular seu orgulho. Em suma, em vez de ferir a dignidade de Linnea, os gestos grosseiros voltam-se, como em um espelhamento, sobre ele próprio, revelando uma incapacidade infantil de lidar com o desejo frustrado. Dominando, infantilizando e descartando seu sedutor, Linnea rompe, momentaneamente, a cadeia de triangulações que ele encabeça e demonstra que sua sedução aparentemente irresistível pode eventualmente se bater contra pequenos atos de resistência.

No caso de Sueleen e Wade, a ruptura é mais sentida, até porque o laço que os une é mais profundo. Desde a primeira aparição dos dois personagens, na lanchonete do aeroporto, o foco narrativo 
sublinha a relação de amizade e camaradagem - as brincadeiras no ambiente de trabalho, a carona diária na volta à casa - que não pode ser atribuída a uma afinidade racial, pois ela é branca e ele negro, e nem de gênero, devendo-se, talvez, a uma experiência de classe em comum: o fato de viverem no mesmo bairro decrépito, de executarem o mesmo tipo de trabalho desprestigiado, de serem igualmente desprezados pela oficialidade política e empresarial de Nashville. Nesta última cena dos dois juntos, esse alinhamento de classe emerge como uma confiança mútua, revelada pela proteção de Wade contra as investidas de Del, por sua liberdade de falar francamente ("Sueleen, você não sabe cantar!") e pelo convite à conservação da amizade, longe da cidade hostil: "eu estou indo embora pra Detroit e, se você quiser vir comigo, é só me acompanhar". Porém, desde o início, o ponto de vista narrativo também sublinha que os dois estão divididos pelo modo como se relacionam emocionalmente com o show business country. Enquanto Sueleen idolatra os stars da indústria e sonha conviver com eles, Wade só pensa em escapar da cidade venal, cujos stars só cantam "por dinheiro". Na sua absoluta incapacidade de autocrítica, Sueleen representa o sujeito iludido pelas promessas falsas da indústria, enquanto Wade, seu contraponto, tem a função de "espírito negativo" na história, um ponto de vista reverso ou uma voz dissonante no meio do monólogo laudatório que a cidade realiza sobre si. A frase utilizada para alertar Sueleen ("Eles vão pisotear na sua alma; eles vão te matar nessa cidade, menina") é o avesso de tantos elogios feitos anteriormente a Nashville e às instalações de sua vigorosa indústria fonográfica.

No momento em que Sueleen vislumbra uma possibilidade efetiva de juntar-se às estrelas da cidade, as opiniões contrárias dos dois tornam-se incompatíveis; o laço de classe precisa então ser rompido, pois as pretensões de Sueleen dependem de sua capacidade de se desembaraçar de quaisquer amarras a seu movimento. No strip-tease, ela já se livrara de um impedimento moral, agora terá de remover Wade, a "má consciência" que insiste em sublinhar suas fraquezas, manchando, com uma previsão excessivamente realista, os sonhos que ela acalenta. Entretanto, a 
progressão do quadro temático na sequência do Parthenon, que Sueleen antecipa em um convite indireto ao espectador ("Vá ao Parthenon e você verá com seus próprios olhos"), confirma a exatidão do prognóstico ("Eles vão te matar nessa cidade, menina"). Embora não seja ela a vítima de assassinato, a visão da morte violenta da estrela querida produz em Sueleen uma estupefação que bem poderia ser lida como o sinal exterior de uma "alma pisoteada"; o destino da cantora, no caso, serve apenas como reiteração do que pode custar o esforço de tornar-se "uma estrela tão grande quanto Barbara Jean".

Feita a "leitura cerrada", cena por cena, do quadro inteiro, verifica-se que, a despeito da diversidade de contribuições dos atores, uma estrutura temática em comum emerge sobre a recorrência de gestos, figuras e temas: Del segura Barnett, Barnett segura Barbara Jean, Del segura Sueleen; Barnett beija a testa de Barbara Jean, Tom beija a face de Linnea, Del tenta beijar Sueleen na porta de casa; Barnett silencia Barbara Jean ao retirarIhe o microfone, Sueleen abandona o microfone, sai do palco e é coagida a fazer uma apresentação silenciosa, Linnea simbolicamente retira a voz de seu sedutor ao ensinar-Ihe linguagem de sinais; Barnett admite ter caído em uma armadilha da qual tenta sair comprometendo-se ainda mais, Linnea torna-se presa de uma sedução, apesar do aviso indireto do sedutor ("É um lugar chamado 'Sem Saída'”), Sueleen desce de um alçapão para ser subjugada por um grupo de homens; vaias e palmas usadas como elementos de coesão, no nível da montagem, e como armas de ataque contra artistas que não querem ceder, passam, "reviradas", de uma cena a outra.

Neste inventário de recorrências, uma ação se sobressai como o princípio ordenador e como a figura que sintetiza o problema geral do quadro. Trata-se do gesto de "tirar a roupa", em suas duas faces antagônicas ("tirar a roupa para alguém", "arrancar a roupa de alguém"), executado explícita ou simbolicamente: Barbara Jean "se despe" diante da plateia, expondo a vida psíquica fragmentada, e a plateia arranca suas últimas proteções, com vaias, forçando-a a despir-se de seus princípios políticos; Tom 
atira, insolentemente, a jaqueta que Mary esquecera no palco para, logo em seguida, simular seu próprio desnudamento na letra de "I'm Easy"; Sueleen é forçada, pela algazarra da plateia e pela sedução de Triplette, a realizar um strip-tease; Linnea inverte o sentido do gesto, recuperando uma peça íntima e vestindo-se para ir embora. São expressões gestuais parecidas, porém distintas, que representam os sentidos contraditórios de um mesmo Gestus: perda da dignidade, exposição da intimidade, exposição de fragilidades, perda de valor de mercado, violência de classe contra o corpo.

O mero desdobramento de um gesto em diferentes expressões não faz emergir um Gestus. Só na medida em que o foco narrativo atribui um significado político-histórico a esse gesto é que ele se transforma em Gestus capaz de criar uma coerência temática para o quadro e exprimir uma avaliação do problema representado.

"Gestus não significa mera gesticulação. [...]. Uma linguagem é Gestus quando está baseada num gesto e é adequada a atitudes particulares adotadas pelo que a usa, em relação a outros homens. [...]. Nem todos Gestus são sociais. [...]. Os esforços para manter o equilíbrio numa superfície lisa só resultam em Gestus social se a queda significa um embaraço diante dos outros, isto é, uma perda de prestígio social e de valor de mercado. [...] o Gestus social é o gesto relevante para a sociedade, o gesto que permite conclusões sobre as circunstâncias sociais." 262

As ações de despir-se e de despir alguém não carregam, em si mesmas, nenhum sentido social; porém, quando são representadas de tal modo que significam a capitulação de sujeitos oprimidos diante da classe opressora e o exercício do poder econômico dessa classe, tais ações são arrancadas de sua banalidade cotidiana para "valer como um ato histórico fatídico, com consequências importantíssimas."263 Discutindo a criação de "efeitos de distanciamento" no cinema,

${ }^{262}$ BRECHT, Bertolt. A Música-“Gestus”. in: Teatro Dialético. p. 78 - 79.

263 JAMESON, Fredric. Brecht and Method. p. 100. 
"[Pascal] Kané argumenta que o Gestus social é simplesmente a representação de relações sociais, que se oferece ao espectador para a sua avaliação: 'o gesto não ilustra, mas, ao contrário, torna incomum o processo que está sendo representado."”264

Portanto, ao oferecer os vários aspectos de "tirar a roupa" como exteriorizações de um Gestus, o foco narrativo os desnaturaliza, quer dizer, revela seu sentido histórico e social, salientando-os como sinais de um problema a ser examinado.

Exterioridade e objetividade são características da representação construída ao redor do Gestus, que se exprime não apenas na mímica do ator ou no gesto coreográfico, mas também na fala. Por exemplo, quando Triplette diz "Volta lá e termina seu show", o elemento de coação presente no Gestus torna-se objetivo não em um gesto (por exemplo, um empurrão), mas em um imperativo eufêmico. Quando combinadas de modo a representar determinada ação com sentido social, a fala e a gestualidade (pense-se no contraponto criado pela narração entre uma letra de música que fala em disponibilidade afetiva e imagens de confinamento) resultam numa forma expressiva "em que as contradições se fazem ver. Gestos e Gestus transmitem as contradições em realidade" fílmica. ${ }^{265}$

O Gestus tem uma função "iluminadora" na cena; na sua expressão se definem os contornos de um problema ao mesmo tempo político e moral, que a roteirista do filme sintetizou de forma cristalina: "quem quiser chegar lá, em algum ponto terá de tirar a roupa". Sobre o conceito de Gestus, Kurt Weill afirma que a música "consegue reproduzir o Gestus que ilustra um acontecimento no palco; ela pode criar um tipo de Gestus básico (Grundgestus), forçando a ação a assumir uma atitude particular que elimina toda a dúvida e equívoco sobre o incidente em questão."”266 No Gestus de "tirar a roupa" está colocada uma questão política geral - como discutir democracia e

\footnotetext{
${ }^{264}$ LELLIS, George. Bertolt Brecht: Cahiers du Cinéma and contemporary film theory. p. 120.

${ }^{265}$ BORNHEIM, Gerd. Brecht: a estética do teatro. p. 283.

${ }^{266}$ WEILL, Kurt. Uber den gestischen Charakter der Musik. apud in: WILLETT, John (org.). Brecht on Theatre. p. 42, nota.
} 
liberdade quando se tem um sistema econômico que constantemente exige concessões que beiram a prostituição? - que instaura uma coerência expressiva para uma "fábula" heterogênea que, do contrário, se dispersaria na variedade de seus elementos de composição.

"A tarefa fundamental do teatro reside na 'fábula', composição global de todos os acontecimentos-gesto, incluindo juízos e impulsos. [...]. Cada acontecimento comporta um 'gesto' essencial. [...]. Pela agrupação das personagens em cena e aos movimentos de grupo, há que alcançar a necessária beleza, principalmente através da elegância, da elegância com que são apresentados e expostos ao olhar do público todos os elementos que constituem esse 'gesto'”267.

No momento de "viabilizar" a expressão da "fábula", o Gestus se torna uma técnica de representação e de composição que permite solucionar um problema de ordem prática, a saber: como juntar materiais diversos, compostos por artistas não especializados, e às vezes resultantes de contribuições feitas em momentos distintos da produção. O estabelecimento de um Gestus a ser exposto ao longo do quadro temático contribuiu para a superação dessa dificuldade, fornecendo uma estrutura para a livre improvisação dos atores e um princípio organizador para a montagem de suas contribuições. Por exemplo, como a cena do Opry Belle é construída em torno de um Gestus, Ronee Blakley pôde compor um monólogo para sua personagem na noite anterior à filmagem, sem com isso prejudicar o encadeamento narrativo com as outras sequências no episódio. Muito pelo contrário, na medida em que sua contribuição esclarecia o Gestus, ela já apontava para seu aproveitamento posterior na montagem que, ao contrário do que se poderia pensar, não se transforma em "colcha de retalhos" ao acolher materiais com origem diversa. De maneira parecida, a contribuição de Ned Beatty, que melhorou a cena do striptease, ao sugerir uma cumplicidade mais ambígua entre as personagens envolvidas, pôde ser incorporada, ainda que isso obrigasse os montadores a eliminar antecedentes da cena já filmados.

${ }^{267}$ BRECHT, Bertolt. Pequeno Organon para o Teatro. in: Estudos Sobre Teatro. p. 128. 
No momento da montagem, novas constelações puderam ser formadas, criando, por exemplo, várias sincronizações entre a letra das canções e os problemas apresentados na imagem. Centrado na exposição do Gestus, o ponto de vista narrativo seleciona os materiais, cortando onde é necessário, modificando o sentido de determinada contribuição, de acordo com o ponto onde é inserida, saltando entre as cenas e reunindo-as, na montagem paralela, por meio de recursos de coesão que não obedecem à sequencialidade narrativa. No engenhoso trabalho de "cortar e colar", a reiteração de gestos significativos produz um efeito estético parecido com o de rimas e paralelismos sintáticos na poesia; ela ressalta o discurso fílmico como um arranjo por meio do qual a "fábula" se torna viável enquanto "heterogeneidade organizada", um arranjo criativo que agrada aos sentidos, revelando no Gestus uma mediação entre o trabalho coletivo e uma forma acabada cuja beleza reside na inteligência com que são resolvidos e expostos problemas de ordem prática. 


\section{6: para terminar, um assassinato}

O último quadro temático se liga ao anterior por meio de uma tênue ponte narrativa do tipo "antecipação/confirmação". Concluindo a discussão na porta de sua casa, Sueleen desafia Wade, que não acredita que ela possa ser uma grande estrela: "Pois vá ao Parthenon e você me verá cantando ao lado de Barbara Jean." Com exceção de uma inserção no meio das cenas que compõem a longa sequência final, todo o quadro seguinte se passa no Centennial Park, em torno da réplica do Parthenon. A longa sequência reúne todas as personagens (menos Connie White) em um mesmo espaço, atando as pontas da narrativa e apontando possíveis conclusões das questões abordadas até então. Ao retomar uma série de recursos técnicos e estilísticos utilizados em toda a obra, a sequência serve também como objeto para a conclusão da análise que vimos fazendo até aqui.

Tomada noturna de um zepelim exibindo os slogans de campanha de Walker: "Novas Raízes Para a Nação/ Partido da Substituição". A imagem recupera a primeira tomada diegética do filme, em que os mesmos slogans eram exibidos sobre o furgão de campanha no seu percurso pelo centro comercial da cidade, indicando que a próxima sequência ata os pontos extremos da narrativa. Na trilha sonora, uma voz "manchada" por certo nível de ruído e reverberação sugere uma narração emitida por algum meio técnico:

"Há menos de um ano, um homem chamado Hal Phillip Walker entusiasmou um grupo de estudantes universitários com algumas perguntas: você já subiu em um monte alto, num dia de muito vento, para ouvir os frutos do carvalho rolarem morro abaixo? Já caminhou à beira do arroio nos vales, rememorando enquanto caminhava? Para você, o natal tem cheiro de laranjas?"

Numa espécie de "fusão invertida", o rosto de um homem de meia idade surge misturado à imagem do zepelim, tornando-se progressivamente mais definido até permanecer sozinho na tela. Trata-se de 
Howard K. Smith, âncora do telejornal ABC Evening News, que ficara conhecido após interromper os créditos de encerramento de um programa especial sobre as primárias presidenciais na Califórnia, para dar a notícia do assassinato de Robert F. Kennedy, na madrugada de 5 de junho de 1968. A baixa qualidade da imagem indica que estamos diante de uma tela de TV, embora ainda não vejamos o quadro do televisor. "Tais perguntas talvez fossem apropriadas para um discurso inaugural, mas não para lançar uma campanha presidencial", prossegue o âncora. Em lento e progressivo zoom-out, o "olhar da câmera" se descola da imagem para revelar sua fonte (um televisor colocado sobre uma mesa de piquenique) e o contexto imediato em que ela foi inserida: na borda inferior do enquadramento, uma mulher realiza algum tipo de atividade manual; na borda superior, no segundo plano, crianças brincam sobre o gramado do Centennial Park. Nenhum desses observadores internos presta atenção no televisor ligado no centro do plano, nem na reportagem que ele veicula:

"Mesmo quem acompanha a política de perto não deve ter dado muita atenção a Hal Phillip Walker e seu Partido da Substituição, vendo-os como um montinho de neve na encosta da montanha; o verão, ou quem sabe até mesmo a primavera tardia, certamente daria cabo dos dois. Bom, agora que o verão e, junto com ele, as primárias presidenciais, pesam sobre nós, enquanto aquele monte de neve continua no mesmo lugar, talvez nós devamos prestar mais atenção."

Ao trazer a reportagem para dentro da tela de cinema, inserindo-a na tessitura de uma cena banal, o "olhar narrador" representa a incorporação cotidiana da política como um assunto que gera pouco interesse. Neste sentido, é possível pensar na cena como uma reiteração das diversas passagens do furgão de Walker por uma série de espaços públicos no filme, em que ele tampouco era notado por seus espectadores. A sobreposição entre a câmera de Altman e a tela de TV traz ainda à memória o desdobramento da ancoragem do ponto de vista narrativo efetuado pela reportagem de Bill Jenkins no aeroporto, indicando, mais uma vez, que o discurso reitera fragmentos, encaminhando a exposição para uma síntese. 
O movimento de "sair do enquadramento" do discurso televisivo para retornar à narração fílmica é acompanhado por desdobramentos na trilha sonora: se, no início da tomada, a voz de Howard K. Smith era a única fonte apresentada ao ponto de audição do espectador, no momento em que a sua imagem compete com outros elementos visuais, outros ruídos demandam nossa atenção. A contradição entre a seriedade do assunto e a leveza da cena de um "domingo no parque" não é sublinhada no discurso fílmico, que parece mais empenhado em definir a paisagem ideológica em contraste com a qual será possível identificar os efeitos de estranhamento produzidos no restante da sequência. Esses contrastes começam a surgir no próximo plano, em que um trecho da reportagem, agora fora do campo, transformada em "narração do filme", é desmentido pela imagem; enquanto um movimento panorâmico acompanha um profissional técnico esticando um cabo até um enorme palanque onde outros tantos trabalham para a realização do comício, ouvimos a voz de Smith em off dizer:

"Hal Phillip Walker é, de certo modo, um homem misterioso. Depois de surgir, não se sabe de onde, com um punhado de estudantes e quase nenhum profissional, ele conseguiu vencer três primárias presidenciais e agora tem grandes chances de vencer uma quarta, no Tennessee."

A frase identifica o objetivo do comício como parte da campanha às primárias no Tennessee e instaura uma contradição entre o discurso fílmico e a narração de Smith: enquanto este descreve Walker como uma espécie de azarão, um amador apoiado por estudantes, aquele sublinha o aparato técnico e profissional por traz de sua campanha. Retrospectivamente, esta contradição joga luz sobre o papel representado pela fala gravada de Walker em todas as cenas anteriores; assim como a reportagem de TV, a fala do político transmitida por um sistema de som atuara como uma "instância épica" inserida no universo ficcional. As contribuições que estes "narradores internos" trazem à cena são variadas: ora eles chamam a atenção para determinados elementos cênicos, ora expõem algum problema específico e outras tantas vezes contradizem aquilo que se vê na tela. 
Corte no eixo da imagem. Numa tomada frontal, vemos trabalhadores técnicos empurrando uma caixa, enquanto são vigiados de perto por policiais. No plano de fundo, está o palanque de Walker e, atrás dele, a colunata do Parthenon, que o "olhar da câmera" abarca em sua totalidade conforme vai abrindo o enquadramento. O movimento de "expansão do ponto de vista" na imagem é acompanhado pela narração de Howard K. Smith, que associa Walker a um quadro político mais amplo:

"Uma vitória no estado do Tennessee traria um significado adicional à campanha, pois somente uma vez, nos últimos cinquenta anos, o candidato escolhido pelo Tennessee não ganhou a eleição presidencial. Não resta dúvida de que muitos americanos, especialmente aqueles alinhados com partidos políticos, gostariam que Hal Phillip Walker fosse embora, desaparecesse como a neve no fim do inverno para só voltar em uma estação mais conveniente."

O trecho do discurso associa Walker a John F. Kennedy, o único presidente eleito nos cinquenta anos anteriores sem os votos do Tennessee; com isso, a narração recupera a fala apaixonada em que Lady Pearl sustentava ser preciso "rachar o crânio" dos eleitores batistas que não votaram em Kennedy, o "melhor candidato", apesar de católico. Indiretamente, o tema do assassinato político é trazido à baila; na referência a Kennedy, na revisitação ao discurso de Pearl e na alusão metafórica a uma eliminação de Walker (que ele "desapareça como a neve") em resposta ao desejo de "muitos americanos" que não encaram o momento político como uma "estação conveniente" a este tipo de candidato.

Assim como o discurso de Walker, a fala de Howard K. Smith foi escrita por Thomas Hal Phillips, de modo que as homologias estruturais entre os dois "olhares épicos" também estão relacionadas à autoria em comum. A permutabilidade dos pontos de vista figurados pelos dois "narradores diegéticos" é sublinhada em um plano-sequência que acompanha a chegada do furgão de Walker ao Centennial Park. Divergindo de todas as suas aparições anteriores, o carro de som do político surge silencioso na imagem, 
trocando de lugar com o âncora de TV, que ficou momentaneamente invisível para substituí-lo na trilha sonora. Em seguida, o "olhar da câmera" distancia-se do furgão para captar todo o gramado em frente ao Parthenon; enquanto o veículo de campanha cumpre uma trajetória circular sobre o espaço livre, a narração de Howard K. Smith comenta seu movimento e resume os pontos nodais de sua plataforma política, que até aqui fora apresentada em fragmentos esparsos:

"Mas aonde quer que ele esteja indo, parece que Hal Phillip Walker chegou para ficar, pois é um candidato com apelo genuíno. É preciso admitir também a coragem deste homem, concorrendo à presidência, disposto a combater grandes empresas petroleiras, eliminar subsídios agrícolas, cobrar impostos das igrejas, abolir o colégio eleitoral, modificar o hino nacional e afastar advogados da administração pública, especialmente do Congresso."

Um corte para a tomada de início (televisor sobre a mesa, mulher à direita do enquadramento, crianças ao fundo) reconduz a voz do apresentador de TV à sua ancoragem diegética e refaz, em um "gesto de montagem", a progressão argumentativa de seu discurso, que também recupera o início para fazer um balanço final:

"Bem, neste ponto, o mais prudente a dizer é que a maioria de nós não sabe como responder a Hal Phillip Walker, mas eu pelo menos posso responder a uma de suas perguntas; na verdade, o natal sempre teve cheiro de laranjas, para mim."

Com esta frase, é questionada a possibilidade de uma fala "neutra" na televisão, já problematizada pelas escolhas do repórter Bill Jenkins na sequência do aeroporto. Se em seu discurso inaugural, Hal Phillip Walker fizera a pergunta como um apelo aos eleitores para quem o natal não é uma experiência alegre, ao respondê-la, o âncora de TV ao mesmo tempo se separa do eleitorado de Walker e se define como membro de uma classe social para quem o natal "sempre tem cheiro de laranjas".

Por meio do âncora associado ao jornalismo político, a narração traz mais um dado da realidade para o universo ficcional e retoma a 
primeira tomada diegética, em que Walker fazia referência às eleições presidenciais de 1976. As possibilidades de leitura alegórica se multiplicam: a ascensão do candidato independente, cujo discurso pseudorradical sequestra elementos da plataforma histórica da esquerda, pode ser uma reencenação do papel representado pelo segregacionista George Wallace nas eleições de 1968, fragmentando a oposição e contribuindo indiretamente para a vitória de Nixon. Também é possível ver em Walker uma alegorização do próprio Nixon, com sua tentativa de formação de um bloco hegemônico a partir de uma plataforma pseudopopulista. Uma terceira interpretação seria a de que a "possibilidade narrativa" de Walker não alegoriza os dois candidatos do passado recente, mas indica a permanência das condições que os produziram, funcionando como um alerta sobre a possibilidade do surgimento de novos "Nixons e Wallaces" nas eleições de 1976.

Essa incorporação da política como assunto do noticiário cotidiano é desdobrada em "Trouble in the USA", uma canção que efetua uma espécie de crônica do momento histórico, relatando desde a crise do petróleo até o caso Watergate. Tocada de modo extradiegético, ou seja, sem que seu ponto de emissão seja identificado no universo ficcional, a canção exprime um "olhar externo" em relação ao assunto que ela comenta: a chegada de Walker ao Centennial Park. O "resumo" dos acontecimentos prementes daquele início de década vem na forma de uma série de perguntas retóricas:

"Hoje, nosso país chora pedindo paz.

Tem coisa errada nos EUA.

Watergate é o que vem à cabeça.

Como será o próximo ano?

Haverá tristeza, lágrimas e dor?

Ou será que o Sol se recusará a brilhar?

Como será o próximo ano? 
Hoje em Nashville, eu ouvi dizer:

Falta de comida, está pra acontecer,

Enquanto, em Denver, há falta de gasolina.

Como será o próximo ano? 268

A função retórica das perguntas é desdobrada nas imagens que elas comentam: as tomadas que enfocam a chegada de Walker, sem mostrar o personagem. Assim como a canção se indaga sobre problemas já expostos ao longo do filme, a narração "encena" um esforço de aprisionar a voz de Walker em um corpo, dando uma fisionomia reconhecível ao político. O jogo de "apresentar sem mostrar" emerge de dois planos-sequência: no primeiro, o enquadramento extremamente amplo das alamedas do parque não permite discernir figuras humanas dentro de automóveis que se movem rapidamente na direção do espectador; no segundo, o "olhar da câmera" tem seu campo de visão obstruído pela colunata do Parthenon, de modo que só consegue vislumbrar fragmentos do carro oficial, mas nunca de seu ocupante.

Com isso, frustra-se a expectativa criada pela primeira tomada diegética, quando a circulação do discurso gravado na avenida central anunciara uma figura "acusmática", ativando no espectador o desejo de vê-la transformada em personagem. Neste caso, o ímpeto crítico do filme, que não poupou nenhuma de suas personagens de um desmascaramento ideológico e moral, trazia necessariamente a promessa de desmonte gradual do fascínio fetichista criado pela existência apenas acústica do político em campanha. Não por acaso, Michel Chion, teórico do uso narrativo do som no cinema, compara o desvelamento progressivo de "acusmas" fílmicos, tais como Walker, a um striptease feminino, movimento cujo termo é justamente a consciência traumática até então encoberta por fetiches:

\footnotetext{
268 "Our country cries for peace today./ There's trouble in the USA./ Watergate is the sound that rings./ Wonder what this year will bring./ Will there be sadness, tears or pain,/ Or will the sun refuse do shine?/ Wonder what this year will bring./ Down in Nashville, I heard today,/ Shortage of food is on its way,/ While up in Denver gas shortage rings./ Wonder what this year will bring."
} 
'O processo de 'desacusmatização', o desvelar de uma imagem e, ao mesmo tempo, de um lugar (o corpo humano e mortal onde a voz ficará aprisionada a partir deste ponto), lembra em muito um strip-tease, pois se trata de algo progressivo, que não ocorre necessariamente de uma só vez. Da mesma forma que os genitais femininos são revelados no ponto final do ato de despir (e a partir daí a negação da ausência do pênis já não é possível), há também um ponto final no processo de 'desacusmatização' - a revelação da boca de onde a voz é emitida. [...]. Enquanto o rosto e a boca não são completamente revelados, enquanto o olho do espectador não tiver 'verificado' a coincidência entre a voz e a boca (uma verificação que precisa ser no mínimo aproximada), a 'desacusmatização' é incompleta e a voz retém sua aura de invulnerabilidade e seu poder mágico."269

Portanto, como a condição de que se revele o ponto de emissão da voz de Walker não é satisfeita, parte do fascínio fetichista de sua figura é mantida até o final. Porém, há uma novidade nesta sua última "aparição": pela primeira vez, ouvimos sua voz "diretamente", e não por meio de sistemas de som identificados na diegese. Em um plano geral, em que não se podem distinguir as personagens na imagem, uma figura se aproxima do carro do político; na trilha sonora, ouvimos a voz Triplette avisar que Walker terá de esperar uma hora, até que os shows tenham terminado. Então, aquele "acusma" que "assombrara" praticamente todos os quadros temáticos no filme, a partir do sistema de som montado sobre o furgão de campanha, chega, pela primeira e única vez, ao ponto de audição do espectador, mediado apenas pelo discurso fílmico: "Não tem importância, John; assim eu vou ter mais tempo para preparar meu discurso".

Se, por um lado, o ponto de vista narrativo não dá uma fisionomia reconhecível ao tipo de figura política representada por Walker, por outro, a "materialização" do personagem na trilha sonora sugere que sua figura misteriosa não é uma miragem, mas sim uma ameaça com existência concreta no universo ficcional. Essa "desacusmatização" incompleta de Walker obedece à lógica argumentativa traçada ao longo do filme: no momento em que o mercado se sobrepôs à política e a perspectiva da revolução popular foi

${ }^{269}$ CHION, Michel. The Voice in the Cinema. p. 28. 
removida do horizonte, os embates entre os que pretendem conservar e os que buscam modificar a sociedade vigente se transformam em disputas para decidir quem irá administrá-la tal como se encontra. Neste contexto, questões de fisionomia e de contornos se tornam irrelevantes; Walker pode parecer-se com Nixon, Wallace, Carter ou qualquer outra "estrela política" que se imagine.

Além disso, o fato de que a narração tenha escolhido o som, em vez da imagem, para ancorar o personagem à ficção deve ser encarado como mais um desafio à recepção excessivamente dependente do olhar. Na representação criada por Nashville, as bordas do enquadramento e, principalmente, o burburinho no extracampo, oferecem tanto material a ser explorado e conhecido quanto os objetos centrais de atração visual. Este tipo de narração, que expande o campo de possibilidades para a atividade intelectual do espectador, compartilhando com ele as suas próprias incertezas a respeito dos acontecimentos narrados, realiza em meio fílmico o princípio épico de que a obra deve estar em constante interlocução com o público.

Entretanto, para a crítica zelosa das categorias dramáticas e romanescas tradicionais, essa "abertura ao diálogo" com o espectador é sinal de falhas estéticas no acabamento do filme. Para Robert Kolker, por exemplo, a montagem de Nashville, que o presente estudo qualifica como dialética, seria tão-somente uma extensão da "estrutura de montagem paralela e alternada, típica do filme americano convencional." ${ }^{270}$ Evidentemente, não será necessário repetir nosso argumento, qual seja, o de que a representação épica de Altman é, antes de tudo, uma refuncionalização do aparato, uma apropriação crítica do repertório do cinema convencional. Neste sentido, o trabalho que produz efeitos de estranhamento, desmonte ideológico, utilização expressiva de clichês, etc., precisa pressupor, e muitas vezes reconstituir, a cena naturalizada, a composição tradicional, etc., como um ponto de partida de uma empreitada crítica.

${ }^{270}$ KOLKER, Robert. A Cinema of Loneliness. p. 376. 
Descontando-se uma pulsão prescritiva no texto de Kolker, evidenciada pela insistência recalcitrante de que a técnica fílmica "não permite que o espectador se torne um participante" na construção do sentido e de que "nem mesmo Altman e sua roteirista podem mudar o status imutável de uma obra imaginativa enquanto objeto separado e inviolável" ${ }^{271}$, talvez sua miopia crítica possa ser atribuída a uma incapacidade de atinar para a mediação do trabalho de Altman, viabilizando a reconstrução de uma paisagem ideológica e o seu desmonte na representação épica. Ainda que o filme resultasse, como acusa Kolker, em "ambiguidade e evasão", o que não é o caso, o fato de ele fazer avançar as possibilidades colaborativas no set de filmagem, desafiando a separação industrial entre elaboração e execução do trabalho criativo, dentre tantas outras intervenções técnicas, já desautoriza a afirmação de que se trata de um filme convencional.

Demonstrando não ser evasiva em relação aos problemas históricos de seu tempo, a narração se vale, mais uma vez, de Wade, para exprimir uma avaliação dos caminhos que o país estava tomando. Enquanto Walker atravessa as alamedas do Centennial Park, o público começava a se aglomerar na área próxima ao Parthenon. Em uma tomada intercalada aos dois planos-sequência que mostram a chegada do político, vemos a picape de Wade movendo-se no sentido contrário àquele do público; na trilha sonora, a voz do personagem, cujo rosto não aparece na cena, mistura-se ao ponto de vista narrativo, exprimindo um julgamento: "Vocês estão todos na direção errada. Está todo mundo na direção errada". Não custa lembrar que o personagem já fora o porta-voz de outras três sentenças esclarecedoras ao longo do filme: "Essa daí só canta por dinheiro", sobre a venalidade de Barbara Jean, no aeroporto; "Ele é o preto mais branco de Nashville", aludindo às concessões feitas por Tommy Brown à indústria fonográfica da cidade; "Você não sabe cantar, eles vão te matar nesta cidade", tentando abrir os olhos de Sueleen, sobre suas reais possibilidades de estrelato. Os pontos de vista

${ }^{271}$ KOLKER, Robert. A Cinema of Loneliness. p. 375. 
expressos por Wade têm, portanto, o valor de esclarecer para o espectador os nós ideológicos suscitados pela narração. No momento em que sua condenação do caminho que todos estão tomando é misturada ao estribilho que diz "tem coisa errada nos EUA", a narração exibe seu posicionamento em relação aos problemas políticos de seu tempo.

$\mathrm{Na}$ próxima cena, é o espaço narrativo que é tematizado, já apontando para uma conclusão. Após deixar Walker em seu carro, Triplette encontra Del, com quem caminha na direção do Parthenon. A tomada que nos traz os dois personagens é extremamente aberta, de modo que só é possível reconhecê-los por meio de suas vozes, apresentadas em primeiro plano sonoro. Cria-se, com isso, uma contradição entre som e imagem: os personagens minúsculos no enquadramento são grandes na trilha por conta do alto volume de suas vozes. Essa divergência de escala nos assuntos fílmicos se torna mais evidente quando os personagens sobem, com dificuldade, as escadarias do monumento, cujos degraus chegam à altura do joelho. Ao passar entre as colunas, acompanhados por um movimento panorâmico da câmera, eles ficam, por comparação, ainda menores, pondo em xeque a definição de uma "medida humana" para a composição plástica do filme e retomando um problema análogo já apontado na cena da corrida de NASCAR, em que se problematizaram as relações entre voz e ruído na construção da paisagem sonora. Inicialmente dividida entre as vozes dos personagens e a escala monumental da colunata, a atenção do espectador é reunificada quando Del incorpora o espaço cênico como assunto:

"Originalmente, este prédio todo havia sido construído com entulho e gesso. Eles o construíram para a celebração do centenário da Independência, mas as pessoas gostaram tanto que não quiseram demoli-lo depois. Nashville passou a ser chamada de Atenas do Sul e as pessoas gostaram disso. Foi então que resolveram reconstruí-lo. Este aqui foi construído pouco antes de eu nascer."

Ao tematizar a construção monumental, a narração retoma e conclui a exposição da megalomania de Nashville, já explorada nos 
vários letreiros que fazem a sua publicidade, na multiplicação de suas igrejas, no estacionamento repleto de ônibus escolares, nas referências à grandiosidade do Opryland, no mapeamento de seus bares de músicos amadores, na tendência demonstrada por seus habitantes fixos e temporários para todo tipo de atividade comercial. Além disso, a referência ao centenário da Independência relaciona este espaço público à História (o bicentenário seria comemorado em 1976) e às primeiras cenas do filme, em que vimos Haven gravando sua canção bicentenária: "200 Years". O "caso de sucesso" cantado pelo personagem ("Devemos estar fazendo a coisa certa pra durar duzentos anos") ganha um novo questionamento na representação que se faz do Parthenon. A solidez do monumento, um dos poucos elementos da paisagem urbana não modificados pela modernização country, é posta em dúvida pela revelação dos frágeis materiais com que ele foi originalmente construído. A troca do gesso pelo concreto foi capaz de protegê-lo da deterioração natural; porém, diante do poder destrutivo do capital fonográfico, o seu futuro pode ser o mesmo do apelido, "Atenas do Sul", que ele suscitava, e que a indústria country substituiu por "Music City".

De fato, o aproveitamento comercial do monumento cívico para vender o político e os cantores da cidade já indica o começo de seu desmanche, pelo menos em nível simbólico. Uma vez incorporado à estrutura produtiva da cidade, o monumento erguido para comemorar a dominação centenária da classe burguesa norte-americana fica sujeito ao "páthos" que caracteriza toda construção monumental sob o capitalismo: a contradição entre o desejo de deixar marcas concretas e duráveis do poder e um sistema econômico que pressupõe a possibilidade de que tudo possa ser destruído para abrir novas oportunidades de acumulação ${ }^{272}$. Ao associar a canção de Haven ao

272 "O páthos de todos os monumentos burgueses é que sua força e solidez material na verdade não contam para nada e carecem de qualquer peso em si; é que eles se desmantelam como frágeis caniços, sacrificados pelas próprias forças do capitalismo que celebram. Ainda as mais belas e impressionantes construções burguesas e suas obras públicas são descartáveis, capitalizadas para rápida depreciação e planejadas para se tornarem obsoletas; assim, estão mais próximas, em sua função social, de tendas e acampamentos que das 'pirâmides egípcias, 
monumento megalomaníaco, sublinhando sua fragilidade diante das contradições do sistema, a narração lança uma sombra de dúvida sobre a permanência da dominação "cantada" pelas duas obras de cultura. Assim como a linhagem histórica celebrada em "200 Years" não pode assegurar um consenso de antemão, o Parthenon da "Music City" só se sustenta na medida em que ajuda a compor um espaço geográfico propício à acumulação do capital fonográfico ${ }^{273}$; na eventualidade de ele se tornar uma barreira a esta acumulação, nem o material mais sólido poderá impedir que ele venha a "desmanchar-se no ar", junto com toda a paisagem urbana sitiada pelos negócios country.

O "resumo" das reflexões sobre a modernização da cidade continua na cena seguinte, em que Barnett e Triplette, o velho e o novo modo de administrar, disputam o controle sobre o trabalho de Barbara Jean. A discussão entre os dois personagens é filmada sem cortes, em um único planosequência; a câmera baixa, posicionada de frente para o palanque, situa nosso olhar no espaço reservado à plateia, enquanto o enquadramento widescreen delineia um tableau ao longo do qual os personagens avançam e recuam, conforme o embate se desenvolve. Como testemunha, há todo um séquito de fotógrafos jornalísticos trabalhando sobre o tablado.

Barnett sobe ao palco, descobrindo que a condição imposta para a participação de Barbara Jean (não haver pôsteres ou cartazes de campanha durante a sua apresentação) não foi atendida:

Barnett: E essas cadeiras aqui. Ei, Triplette, Delbert, nós não precisamos de todas essas cadeiras. Nós não vamos usar uma

dos aquedutos romanos, das catedrais góticas'” BERMAN, Marshal. Tudo que é sólido desmancha no ar. p. 123.

273 "O desenvolvimento capitalista precisa superar o delicado equilíbrio entre preservar o valor dos investimentos passados de capital na construção do ambiente e destruir esses investimentos para abrir espaço novo para a acumulação [...]. Em consequência, podemos esperar testemunhar uma luta contínua, em que o capitalismo, em um determinado momento, constrói uma paisagem física apropriada à sua própria condição, apenas para ter de destruí-la, geralmente durante uma crise, em um momento subsequente." HARVEY, David. A geografia da acumulação capitalista. in: A Produção Capitalista do Espaço. p. 54. 
banda aqui. (Olhando para cima, vê a enorme faixa com os slogans de Walker) Eu não... Eu não acredito! Vocês dois estão de brincadeira? Vocês estão vendo o que eu estou vendo, ou será que eu estou...? Que diabo está fazendo este cartaz aí em cima, Triplette? Vamos lá, nós tínhamos um acordo, ou não tínhamos? Sem cartazes políticos, sem publicidade, sem nada. (Empurrando uma fotógrafa, que continua seu trabalho). E você? Que diabo você está fazendo? Vai cuidar da sua vida!

Triplette: Barnett, eu cumpri todas as regras que você colocou. Deixei Walker esperando atrás deste lugar, feito um idiota, enquanto sua esposa vem aqui cantar.

Barnett: Bom, por mim ele pode ficar esperando no sol e esturricar. É minha esposa que está doente, ou não é? Agora, eu a trouxe do hospital para estar aqui e você me faz uma dessas? Você é um mentiroso, igual ao seu chefe.

Triplette: (Alterando a voz e apontando o dedo para o peito de Barnett) Eu segui todas as regras que você impôs.

Barnett: Exceto qual delas? O que aquele cartaz está fazendo lá em cima? Ela não vai aparecer aqui se aquele cartaz continuar lá.

Triplette: Eu me ferrei por causa de você.

Barnett: Eu é que vou te ferrar.

Triplette: Agora, você pega a sua esposa e some daqui! E eu vou até aquele microfone e vou dizer a todas essas pessoas que ela não vai aparecer, de novo!

Barnett: Ah, você faria isso? Então vai lá e faz!

Triplette: Tudo bem, vai embora e eu faço.

Barnett: Você faria isso, não é? Você daria essa punhalada nas costas da minha esposa? 
Triplette: Você é que está apunhalando a sua esposa pelas costas, palhaço! Agora não dá mais tempo de tirar aquele cartaz e recolocá-lo novamente!

Barnett: E por que você está gritando na frente desse povo todo? Está tentando me intimidar?

Triplette: Estou tentando ser ouvido.

Barnett: Então tira essas cadeiras daqui e vamos conversar sobre o assunto.

Triplette: (Recuperando o tom servil) Tudo bem, tudo bem, eu tomo conta disso. Não se preocupe.

Barnett: (Voltando-se para o fundo do palco, encenando uma autoridade que acabara de perder) Tirem essas cadeiras daqui. Pelo amor de Deus! Delbert! Onde é que está aquele rato? Por que é que você está se escondendo, seu rato?

A briga entre os dois personagens antecipa 0 assassinato de Barbara Jean em uma forma simbólica, traduzindo o gesto de matá-la em uma figura de linguagem usada nas acusações mútuas. Disparada pelo desentendimento em torno do cartaz sobre o palco, a disputa passa a girar em torno da decisão sobre qual ação "apunhala a cantora", decretando a sua morte: explorá-la, como tem feito Barnett, ou expô-la publicamente, como ameaça Triplette. Transformada em objeto de disputa, a cantora figura a dialética perversa da relação do artista com os meios de seu trabalho: por um lado, ela precisa aproximar-se deles para a sua conservação, fazendo mais um show, apesar da saúde debilitada, e aceitando a ruptura do acordo prévio; por outro lado, são estas mesmas ações que decretam seu fim. Assim, a personagem, retratada como a cantora mais bem sucedida da cidade, se revela uma vítima do mesmo processo contraditório que incorpora o cantor negro por meio de seu embranquecimento, que dá uma chance à amadora na corrida de NASCAR, abafando a sua voz com o ruído dos stock cars, e que decreta o fim da carreira de Sueleen, oferecendo a ela uma primeira chance de cantar ao lado 
das estrelas; para todas essas personagens, os meios de produção de que foram apartadas se voltam sobre elas como meios de coação.

A modernização da cidade eliminava gradualmente o tipo de exploração direta representada por Barnett, marido e administrador da vida de Barbara Jean, substituindo-a pela "opressão corporativa" de organizações como a de Walker. No modo anterior de efetuar a gestão da força de trabalho, os papéis antagônicos de marido e empresário da cantora traduziam as necessidades contraditórias de conservar e explorar ao máximo seu corpo já fragilizado. Esse desenho dialético do personagem e de sua relação com Barbara Jean teve a contribuição de Allan Garfield, o ator que interpreta Barnett. Segundo o relato de Michael Henry, que acompanhou os trabalhos iniciais no set de Nashville, do tratamento inicial proposto por Joan Tewkesbury até as filmagens, 0

"perfil de Barnett modificou-se incessantemente. No roteiro original, ele fazia tudo aquilo que agora é de responsabilidade de Del Reese e de Triplette. Entretanto, Allan Garfield vê no personagem mais do que um 'traficante negreiro': ele é, ao mesmo tempo, pai, marido, guarda-costas, empresário e tirano de Barbara Jean. Ele precisa dela para viver ('Ela é o único puro-sangue de seu haras!'); sua afeição por ela é tão impiedosa, que ele a destrói ao tentar protegê-la.,"274

Triplette é um representante da nova forma de poder que se impõe sobre a cantora; sem nenhuma relação pessoal com ela, o "homem de frente" de Walker se transforma no mediador entre a sua força de trabalho e a "mão invisível" do show business. Ciente de que, numa sociedade entalhada por valores puritanos, a desobediência ao acordo de trabalho é lida como fraqueza moral, Triplette ameaça transformar a teimosia de Barnett em um motivo para desmoralizar a cantora frente a seu público, baixando seu "valor de mercado" e arruinando suas perspectivas de emprego. A medida artística do problema foi lançada numa das cenas de $A$ Letra Escarlate (Nathaniel Hawthorne, 1850), em que Hester Prynne, a heroína, é exposta na praça do

${ }^{274}$ HENRY, Michael. Altmanscope (sur le plateau de "Nashville"). p. 26. 
mercado como punição pelo crime de adultério ${ }^{275}$; a novidade são os meios de intimidação acionados por Triplette: a imprensa televisiva e os repórteres fotográficos. $\mathrm{Na}$ cidade onde o show business vai tomando conta de todas as estruturas de poder, o mando pessoal torna-se gradualmente irrelevante na garantia do bom funcionamento dos negócios; o mercado já desenvolveu seus próprios meios de enquadrar a cantora e reconduzi-la "ao bom caminho".

A intimidação de Barnett recupera ainda a coação de Sueleen no smoker: em ambos os casos, a "parte mais fraca" da relação de trabalho se descobre vítima de uma armadilha, de um contrato leonino forjado pelo empresário dissimulado. Porém, há algumas novidades nesta segunda cena: enquanto o strip-tease de Sueleen ocorre no ambiente fechado do clube noturno, esta se passa em um palanque, testemunhada pelos espectadores internos e pelos profissionais de imprensa; além disso, a teimosia de Barnett força Triplette a trazer à cena o peso do poder que ele representa, algo que, na coação de Sueleen, pudera ficar apenas implícito. Aqui, a estratégia retórica do personagem, que consiste em "colocar-se na defensiva", afirmando tudo ceder ("Eu segui todas as regras que você impôs"), é desmentida por seu gesto de apontar com o dedo o peito de Barnett. Esta exposição pública do exercício do poder levou Helene Keyssar a ler na cena uma alusão ao papel de desmascaramento que a mídia cumpria naquele começo de anos 1970:

"Esta discussão passaria como banal, não fosse a sua exposição pública. Imaginamos que tais manipulações ocorrem sempre por trás de portas fechadas, mas aqui, não apenas o espectador na sala de cinema, mas também transeuntes e repórteres em frente ao Parthenon, são testemunhas da demonstração de poder de Triplette. Neste momento, e repetidamente ao longo da sequência final de Nashville, Altman observa a transparência peculiar de nossa história política recente, fotografando cada gesto sórdido. Para representar os traumas não resolvidos em relação a assassinatos, conspirações e corrupções dos anos 1960 e 1970, torna-se necessário lembrar que fomos agraciados com imagens - estáticas e moventes do que acontecia. Nossas memórias do assassinato de John Kennedy, da Guerra do Vietnã e

${ }^{275}$ HAWTHORNE, Nathaniel. The Scarlet Letter. Rutland (USA): Everyman, 1992. p. $41-49$. 
das audiências de Watergate, são inseparáveis de nossas lembranças de ter visto fotografias ou assistido a projeções televisivas destes acontecimentos." ${ }^{276}$

A interpretação de Keyssar a respeito da construção midiática da história norte-americana nos anos 1970 parece correta, encontrando, inclusive, confirmação em outros pontos do filme, como a reportagem de Bill Jenkins no aeroporto, em meio ao desfile militar com as Tennessee Twirlers, e nesta própria sequência final, com o noticiário de Howard Smith. Entretanto, parece temerária uma avaliação apenas positiva do papel da imprensa, tal como representada no universo ficcional. Lembremos que a presença de fotógrafos na cena não apenas contribui para o desmascaramento de Triplette; ela é também sua aliada na intimidação de Barnett. Assim, a relação entre o poder constituído e a mídia no filme é dialética; uma espécie de jogo duplo de vigilância e dependência mútua, ela não se fixa em uma suposta rivalidade, nem pode gerar qualquer "transparência histórica".

De fato, a avaliação de Keyssar não difere do modo como o senso comum apreendeu a participação da mídia no processo de investigação e julgamento do caso Watergate. Como nos revela Stanley Kutler, a partir de Watergate, tornou-se lugar comum

"a ideia de que os oficiais do governo encaram a mídia como um inimigo natural. Algumas [interpretações] enfatizam as tentativas do governo de manipular e intimidar, enquanto outras sublinham o uso de agrados e cooptação. Mas a administração Nixon, como todas as outras, se valia das duas táticas. Seja qual for a interpretação, os anos 1960 claramente transformaram a relação da Casa Branca com a mídia. Até aquele momento, os grupos de imprensa trabalhando na Casa Branca lembravam um clube de cavalheiros, com a observação de certas regras e amenidades, o que dava um ar de formalidade, privilégio e amabilidade à sua relação com a administração. [...]. Esta relação mudou. [...]. A competição entre a mídia escrita e as comunicações eletrônicas aumentou a pressão pelo dramático, pelo sensacional e pelo instantâneo, nas 'notícias'. A preocupação da mídia era com o momento, o que tornava difícil para oficiais do governo trabalhar na obscuridade [...]. Os novos tempos

${ }^{276}$ KEYSSAR, Helene. Robert Altman's America. p. 167. 
haviam encorajado uma visão crítica e cínica da mídia em relação a pronunciamentos e políticas oficiais. [..]. Evidentemente, ataques à presidência não eram uma novidade. Truman e Johnson haviam sofrido muito na história recente, mas Nixon acreditava ter sido especialmente vitimizado. [...]. Nixon nunca pôde se dar ao luxo de uma observação confiante como aquela de Eisenhower na sua primeira conferência de imprensa: 'Eu não vejo em quê um repórter poderia fazer mal a um presidente, e você?' Os tempos e o presidente haviam decididamente mudado."277

Se os novos tempos muitas vezes colocaram a mídia na posição de adversária política do governo, o acirramento da competição no mercado de notícias aumentou a interdependência das duas instituições, pensadas agora como braços complementares do entretenimento. Enquanto $o$ presidente necessitava dos holofotes e das câmeras para vender sua imagem pública, os repórteres recorriam frequentemente à Casa Branca em busca de matéria-prima para o noticiário. Neste contexto, falar de "transparência" é, no mínimo, arriscado, além de falsificar o modo como as duas formas de poder estão relacionadas em Nashville.

A continuação da sequência no Centennial Park é interrompida por uma breve cena em um cemitério, a única do conjunto que se passa em outro espaço. Trata-se do enterro de Mrs. Green, captado em um só plano-sequência. Enquanto ouvimos um discurso fúnebre, sem identificar seu emissor na imagem aberta, vemos uma figura se levantar no meio do grupo e caminhar na direção do primeiro plano; imediatamente identificamos Mr. Green e, logo em seguida, Kenny, tentando convencê-lo a esperar o término da cerimônia. Desvencilhando-se de Kenny, Mr. Green anuncia suas próximas ações, estabelecendo uma ligação narrativa entre esta cena e a seguinte: "Vou achar Martha. Ela deve um pouco de respeito a Esther". Além de conectar os dois personagens aos acontecimentos no Centennial Park, a cena desautoriza a leitura de uma premeditação do gesto posterior de Kenny, pois o personagem vai ao Parthenon seguindo Mr. Green e não necessariamente para assassinar

${ }^{277}$ KUTLER, Stanley I. The Wars of Watergate. p. $165-166$. 
Barbara Jean. Assim, o prosseguimento da sequência combina causalidade e casualidade: 0 assassinato se relaciona com as diversas pistas deixadas ao longo do filme, mas também resulta de circunstâncias presentes apenas naquele momento preciso.

A próxima cena mostra a chegada de Kenny, Mr. Green e outras personagens ao Centennial Park, no momento em que o show vai começando. Primeiríssimo plano da bandeira norte-americana: ocupando todo o enquadramento da tela widescreen, o símbolo patriótico não permite discernir o espaço onde ele foi posicionado. A composição é extremamente horizontalizada, com as listras da bandeira percorrendo toda a extensão maior da tela. $\mathrm{Na}$ trilha sonora, ouvimos os primeiros acordes de uma canção e um apresentador anunciando um dueto entre Barbara Jean e Haven. No entanto, quem recebe os aplausos é a bandeira, cuja imagem "inflada" persiste na tela, enquanto os cantores se lançam nos primeiros versos: "Quando sinto minha vida perecer, eu te telefono"; "Eu sempre te conserto quanto você se parte". Mais uma vez, o foco narrativo questiona a "medida humana" da representação; no enquadramento, a imagem abstrata da política, figurada pela bandeira nacional, ampliou-se ao ponto de encobrir todo o campo de visão, enquanto o concreto as vozes dos cantores e os aplausos do público - foi lançado para a obscuridade do extracampo.

Um movimento panorâmico no eixo horizontal, acompanhado de progressivo zoom-out, revela o palco com a bandeira acima, o enorme cartaz de Walker ocupando toda a extensão maior da tela e os dois cantores, minúsculos, no centro da imagem. Mais uma vez, surge uma contradição entre imagem e som, pois, na trilha sonora, as duas vozes, longe de serem pequenas, são apresentadas em primeiríssimo plano:

Haven: "Pois cada vez que me feri e saí de controle".

Barbara Jean: "Eu sabia de seus medos, antes que você os revelasse". 
Tomada inversa; de costas para a câmera, os dois cantores prosseguem, em uníssono: "Um, eu te amo, dois penso em você". Corte no eixo da imagem, seguido de planos próximos da plateia, mapeando a chegada do Homem do Triciclo e de Star, marido de Albuquerque. Fora do campo, os dois cantores concluem o estribilho: "três, nunca vou te deixar partir; quatro, sinto sua falta, cinco, quero te beijar e seis, não vou mais te deixar". A narração faz a última frase coincidir com a volta de Wade, que aparentemente resolveu adiar a viagem a Detroit para prestigiar a apresentação de Sueleen. Opal, Martha, acompanhada de Bill, e o soldado Kelly são os próximos a abrir caminho no meio da multidão. Mais uma vez, a plateia é autêntica e a passagem dos atores no meio dela atrai diversos olhares, o que, de certa maneira, rompe a ilusão de realidade e revela que a representação não se restringe ao palco. A chegada de Mr. Green e Kenny é "narrada" pelas vozes de Barbara Jean e Haven, no extracampo: "Quando sinto minha vida desaparecer, como ondas sobre a areia", "Sem nada para substituí-la a não ser a imaginação." Mr. Green se perde no meio da multidão e Kenny se detém, olhando para o palco, de onde os versos dos dois cantores fazem uma leitura simbólica de seu rosto: "Então eu faço minhas rimas e canto minha canção, mas ainda assim ninguém me entende", "Fazer rir nunca foi sua intenção. ${ }^{\text {278 }}$

Corte para uma tomada frontal do palco; câmera baixa, posicionada no meio da plateia. Haven e Barbara Jean concluem os últimos versos, intercalados a imagens de outros cantores, à espera do momento de sua entrada em cena.

Ocupando todo o enquadramento na tomada inicial da cena, a bandeira norte-americana sintetiza, em uma imagem total, suas diversas aparições anteriores como fragmentos de azul, branco e vermelho. As três cores

278 "When I feel my life perishing, I call you on the phone./ I always fix you up when you get broken./ 'Cause every time that I got hurt and went out of control,/ I knew the fears you felt before you spoke them./ One, I love you, two, I'm thinking of you, three, I'll never let you go/ Four, I miss you, five, I wanna kiss you, six, I won't leave you no more./ When I feel my life vanishing like waves upon the sand,/ With nothing to replace it but invention,/ So I make my rhymes and I sing my song, still they don't understand./ To make them laugh was never your intention." 
presentes nos créditos de abertura, na decoração do aeroporto para a recepção de Barbara Jean, nos figurinos de vários cantores, na placa que identifica o Opryland, nas paredes do quarto de hotel ocupado por Mary e Bill e em tantos outros elementos visuais, são finalmente reunidas no símbolo patriótico de onde foram retiradas ${ }^{279}$. Em um movimento análogo, a narração reúne as peças que compõem sua vigésima quinta personagem: a plateia.

"Nashville começa com uma multidão de atores funcionando como extras [a multidão no aeroporto] e termina com uma multidão de extras funcionando como assuntos de documentário, obrigando-nos a aceitá-los como emblemas de uma ordem maior, com o Parthenon de Nashville e três tomadas da bandeira norte-americana apontando naquela direção."280

Atraídos com a promessa de um show e cachorrosquentes grátis, os espectadores reais não mais controlados por estruturas físicas como o auditório do Grand Ole Opry, a plateia do Opry Belle e as arquibancadas do autódromo, traziam imprevisibilidade à cena. Por outro lado, criavam uma "ponte" entre a ficção e a realidade sócio-histórica, funcionando como substitutos do público de cinema. No meio dessa plateia real e desconhecida, a narração inseriu figuras fictícias, neste ponto, já bastante conhecidas:

"Goldblum como o 'Homem do Triciclo', que percorre a cidade fazendo truques de mágica em bares e restaurantes; Shelley Duvall como uma cabeça oca californiana com um chapéu mole e um repertório de penteados malucos; Scott Glenn em um uniforme justo como sua cara. A câmera parece ser distraída por estas personagens e é somente com um sentimento de decepção que nos damos conta de que todos estes doidos de menor importância estão sendo delineados como assassinos em potencial, preparando-nos para a climática cena final."281

${ }^{279}$ Franck Kaush faz uma interpretação inversa, entendendo a sequência final não como um momento de síntese, mas sim de dispersão: "Se a lenta polifonia de Nashville culmina no encontro de todas as personagens na sequência do assassinato, este longo plano-sequência, longe de entrecruzar enfim estes destinos disjuntos e paralelos, trabalha ao contrário para separá-los na dispersão paratáctica de travellings laterais, surdo, finalmente, para este uníssono oco da falta total de implicação das personagens no acontecimento que os encerra e na sua própria existência." KAUSCH, Franck. Le crépuscule des idoles: à propôs de Robert Altman. p. 17.

${ }^{280}$ ROSENBAUM, Jonathan. Afterword: Nashville. in: Essential Cinema. p. 94.

${ }^{281}$ GILBEY, Ryan. It Don't Worry Me. p. 143. 
$\mathrm{Na}$ verdade, essas tomadas iniciais da plateia "bombardeiam" o espectador com informações, sugerindo que ele escolha um foco de atenção: a plateia real, as personagens no meio dela ou as vozes dos cantores no extracampo. No momento em que se encaminha para uma conclusão, o filme mantém a coerência de sua relação com espectador, reconhecendo e encorajando, até as últimas tomadas, a sua capacidade

"de ver por si mesmo. Composto de vários momentos transitórios, o filme alcança seu impacto extraordinário ao fazer uma exigência libertadora: que seus pedaços sejam montados pelo único 'personagem' que consegue ver tudo o que está acontecendo - o espectador."282

Câmera baixa; plano americano de Barbara Jean recebendo os aplausos pelo número anterior. Haven beija sua mão e se retira do palco; o enquadramento vai-se fechando sobre o rosto da cantora, enquanto ela canta os versos iniciais de "My Idaho Home":

“Mamãe e papai me educaram com muito cuidado.

Sacrificaram-se para que eu tivesse um futuro melhor.

Alimentaram-me, cuidaram de mim e me mandaram para a escola.

Minha mãe me ensinou a cantar, papai vivia segundo a regra de ouro.

Quando penso nas crianças sozinhas e amedrontadas,

Abandonadas e soltas como órfãs,

Eu penso em mamãe e em como ela harmonizava com papai.

Nossas risadas ressoavam pelas estradas, pelas praias, até onde a memória alcança."

${ }^{282}$ MICHENER, Charles \& DORF, Martin K. Altman's Opryland Epic. 
Contracampo: plano próximo da plateia. Kenny abre caminho na multidão, com os olhos sempre fixos no palco. Com uma chave que estava pendurada em uma corrente no seu pescoço, ele destranca a caixa de seu violino. A canção continua, em off, até sincronizar-se novamente com a imagem da cantora, em close-up:

"Ainda ouço papai cantar suas velhas canções do exército.

Nós ríamos e contávamos os cavalos que passavam.

Éramos tão jovens e tão unidos.

Podíamos resistir a inundações, incêndios e tempo ruim.

Agora que estou mais velha e crescida,

Ainda amo minha mãe, meu pai e minha casa de Idaho.

Mamãe cresceu nas pradarias do Kansas.

Ela era doce e carinhosa.

As tempestades de areia e os tornados sopravam ao redor dela,

Mas nunca a fizeram tombar.

Papai cresceu mais ou menos sozinho.

Sua mãe morreu quando ele tinha apenas onze anos.

Sete irmãs o educaram,

Mas ele sempre sonhava com sua mãezinha no céu."

Durante a performance da cantora, o jogo de campo e contracampo continua, intercalado por alguns planos curtos de outros setores do palco, enfocando a espera dos cantores e de seus empresários. As imagens são descontínuas, mas a canção, tocada em volume constante, funciona como recurso de coesão no plano da trilha sonora. A sugestão é que os sentimentos estão todos sintonizados no idílio cantado por Barbara Jean. Em mais um 
contracampo, o "olhar da câmera" vai buscar o rosto de Kenny, agora com a mesma expressão ambígua que víramos no show da cantora, no Opry Belle, durante a apresentação de "Dues". Com o olhar fixo no palco e a respiração encurtada, o personagem parece repentinamente agitado. A expressão de "raiva contida" no seu rosto recupera um elemento visual associado a ele na sequência do engarrafamento: a imagem de seu "carro fervendo" embaixo do sol do meio dia. Juntem-se a isso as humilhações posteriores sofridas pelo personagem (a comparação com Howdy Doody, o personagem cômico da TV, o ataque físico sofrido na mesma ocasião, o lugar reservado no Opry Belle, atrás de uma lata de lixo) e começa a ficar claro que a narração lançava os argumentos que sustentam uma teoria do assassinato político: uma sociedade que "pisoteia" gente como Kenny, ao mesmo tempo em que restringe os meios políticos de expressão de sua raiva contida, deve estar preparada para ataques desesperados. A associação da raiva de Kenny com a sociedade e o sistema cultural que o esmaga se dá em uma rápida "troca de olhares"; o personagem faz um movimento com a cabeça, como se notasse algo acima do palco e, no contracampo, a narração exibe os objetos de seu olhar: a bandeira norteamericana ocupando toda a tela widescreen, cortando para um close-up da cantora, concentrada em sua performance:

"Seu pai bebia uísque e tinha um olho afiado.

Vendia remédio para galinhas que os fazendeiros compravam.

Juntos, eles caçavam pelos campos e pelas fazendas.

Quando seu pai morreu, meu pai se consolou nos braços de mamãe.

Pelas estradas (...).,283

283 "Mama and daddy raised me with loving care./ They sacrificed, so I could have a better share./ They fed me and nursed me and sent me to school./ Mama taught me how to sing, daddy lived the golden rule./ When I think of the children alone and afraid,/ Abandoned and wild like a fatherless child,/ I think of my mama and how she could sing/ harmony with my daddy. Our laughter would ring/ Down the highways, on the beaches, just as far as memory reaches./ I still hear daddy singing his old army songs./ We'd laugh and count horses as we drove along./ We 
"My Idaho Home", outra canção composta por Ronee Blakley, cria um idílio rural em que o vigor da gente simples, que sobrevive a tornados, incêndios e tempestades de poeira, é temperado pela presença cotidiana da morte. Na relação do "eu-lírico" com o passado, a letra da canção recupera o Gestus de "200 Years", exposto na sequência dos estúdios. Lá, Haven fazia uma crônica histórica, distorcendo uma linhagem bicentenária de figuras ilustres, de modo a fazê-la desembocar nele próprio, proclamando-se herdeiro dos fundadores da nação americana. Aqui, Barbara Jean traz à tona o passado mítico, tecendo, nos ciclos naturais de vida e morte, o fio da história familiar, do qual ela constituirá o próximo nó, segundos após concluir os últimos versos da canção.

Ao transformar Barbara Jean na cronista de sua própria morte, a narração preserva a ironia da relação entre as personagens e suas canções, sustentando até as últimas cenas o registro crítico com que é tratada a História e o próprio gênero musical, em que Nashville é normalmente classificado. Não apenas por ter sido colocada no momento mais tenso do filme, mas também por ser uma das composições com melhor acabamento estético, "My Idaho Home" tem potencial para criar no espectador um tipo de fascínio entorpecente que põe em risco a possibilidade de seu distanciamento crítico. $O$ perigo da "identificação ilusionista" aqui é contrabalançado com a narração irônica, sem a qual

"o comício final poderia facilmente resultar em um tipo de finale unificador como os que caracterizam os musicais folk desde Oklahoma! Em vez disso, ele é usado para enfatizar a desintegração da América. [...]. A relação entre músicos e público ao longo do filme é [...] radicalmente diferente daquela vista no musical folk. Em vez de formar uma comunidade unida, artistas e público são fisicamente separados por guardas armados, paredes

were young then, we were together./ We could bear floods and fire and bad weather./ And now that I'm older, grown up on my own,/ I still love my mama and daddy best and my ldaho Home./ Mamma grew up on the prairies of Kansas./ She was tender and sweet./ The dust and tornadoes blew round her,/ But they left her straight up on her feet./ My daddy grew up on his own more or less./ His mama died when he was just eleven./ He had seven sisters to raise him, but he dreamed of his mama in heaven./ His daddy drank whiskey and had a sharp eye./ He sold 
de vidro, palcos elevados ou barreiras sociais. Quando Barbara Jean perde contato com a realidade durante uma apresentação no Opryland, a plateia está menos preocupada com a saúde mental da cantora do que com os dólares que perdeu. Assim, não surpreende que a única apresentação gratuita de Barbara Jean termine com o seu assassinato. [...]. No musical folk sintático, a música é uma expressão de amor pela terra. Em Nashville, faz-se música por dinheiro, por influência política e para seduzir mulher casada. Metaforicamente, a música é apresentada como doença mental, como strip-tease e como uma arma. As palavras não mudaram - ainda são carinhosas, amorosas, patrióticas - mas a razão e o modo de apresentação transformam a música em um assunto sujo. [...]. No musical folk clássico, uma união permanente entre homem e mulher civiliza a terra, transformando o caos em cosmos; em Nashville, o comício final acontece no 'Parthenon' apenas para sublinhar a falta de cultura e de civilização que caracteriza a América contemporânea. [...]. Ao explodir a própria sintaxe em que se baseia o musical folk, Nashville nos oferece uma crítica terrivelmente efetiva da mitologia que alicerça a vida americana no presente."284

Tomada frontal do espetáculo. Concluída a canção, Haven entra em cena carregando um buquê de rosas brancas. Movimentos panorâmicos e de zoom acompanham seu caminhar, acenando para a plateia e "recolhendo" os aplausos para Barbara Jean. Corte para um plano geral, abarcando toda a extensão do palco. Um ruído de tiro na trilha sonora é seguido pela queda de Barbara Jean, antes que Haven possa ampará-la. No contracampo, vemos Kenny transtornado. Empunhando um revólver, ele ainda atira duas vezes até ser contido pelo soldado Kelly. A multidão se atira sobre o assassino, enquanto ouvimos mais um tiro. Gritos e confusão generalizada. Corte para o palco; Haven se levanta, perdendo sua peruca no meio da confusão. Com a mão direita, ampara seu braço esquerdo, ferido no ombro. Fora do campo, uma voz ordena: "Tirem Walker daqui". Haven pega o microfone das mãos de Barbara Jean e se vira para o público: "Vocês fiquem calmos agora. Isso aqui não é Dallas, é Nashville. Mostrem a eles do que nós somos feitos. Eles não podem fazer isso conosco em Nashville."

chicken medicine farmers would buy./ Together they hunted the fields and the farms./ When his daddy died my daddy rested in my mama's arms./ Down the highways (...)."

${ }^{284}$ ALTMAN, Rick. The American Film Musical. p. $324-327$ 
A frase recupera o tema do assassinato de Kennedy, ocorrido em Dallas, em 22 de novembro de 1963, associando-o, em negativo, ao ataque à cantora e a ele mesmo, Haven. Enquanto Barbara Jean é recolhida do palco (viva ou morta?) e Kenny é retirado por policiais (vivo ou morto?), Haven tenta reconduzir a vida à "normalidade", propondo o apagamento imediato da ação violenta, por meio da especialidade comercial de Nashville: a música. "Todos vocês, comecem a cantar. Alguém, qualquer um, cante!", diz transtornado. Passa o microfone a Albuquerque, dando-lhe um pequeno empurrão no braço: "Canta!" Com isso, a personagem, cujas tentativas de inserção no meio musical até aqui haviam sido continuamente rechaçadas, é praticamente atirada para o centro do palco, em um movimento ao estrelato que é absolutamente objetivo; embora cantar seja o que ela sempre quis, não é por vontade própria que ela se torna a atração principal do gran finale.

$\mathrm{Na}$ sua situação de "pessoa certa na hora certa", a narração encontra o avesso das condições que produziram o assassino, pensado aqui como "pessoa errada na hora errada"; assim, adensam-se, em "imagem dialética", as relações entre produção industrial da cultura e violência política: o sistema que transforma sujeitos políticos em meros espectadores do processo social, encorajando o surgimento de ataques pontuais no meio da massa espectadora, é o mesmo que produz, no momento conveniente, o star encarregado de reconduzir a sociedade à obediência. É possível que o choque, produzido pela cena e seus desdobramentos, se deva menos à revelação de que o assassino era uma figura "simpática" e a próxima estrela, uma groupie desconhecida, do que à descoberta de que, numa conjuntura sócio-histórica que inviabiliza a ação política transformadora, quer dizer, em um contexto de espetacularização da vida social, sujeitos "inofensivos" podem ser compelidos a tornar-se, alternadamente, um star ou um agente do terrorismo.

Aos poucos, vai ficando mais claro o papel representado pelos assassinatos políticos ocorridos no final dos anos 1960; na História, assim como em Nashville, o autoritarismo, da Nova Direita ou do star 
de última hora, se oferece como o "menor dos males", o "pulso firme" que reconduzirá à ordem a sociedade que o próprio autoritarismo desestabilizou, por meio de seus "agentes do terror".

"Esta democracia tão perfeita fabrica seu próprio inimigo, o terrorismo. De fato, ela prefere ser julgada a partir de seus inimigos e não a partir de seus resultados. A história do terrorismo foi escrita pelo Estado; logo, é educativa. As populações espectadoras não podem saber tudo a respeito do terrorismo, mas podem saber o suficiente para ficar convencidas de que, em relação a esse terrorismo, tudo mais lhes deve parecer aceitável, ou, no mínimo, mais racional e democrático."285

Esta talvez seja uma das lições que se tiram do assassinato de Barbara Jean: diante do "terror" representado pelo ato espetacular de violência política, tornam-se "aceitáveis", para o ponto de vista das personagens, as formas mais variadas de violência econômica, sexual, racial, etc. a que elas são submetidas no decorrer da história; a prova disso é que todas cantam juntas, tentando esquecer as duas vítimas e ajudando a recuperar a funcionalidade do sistema que as produziu. Tal interpretação, entretanto, não pode jamais pretender ser a última palavra sobre o significado político de um filme materialmente tão heterogêneo quanto Nashville. Embora ela nos pareça mais próxima de uma tentativa de "leitura épica", que busca decifrar, na forma artística, a conjuntura sócio-histórica mais ampla, no que tange à composição do quadro de recepção crítica da obra, ela não pode pretender desautorizar nenhuma leitura divergente.

Contudo, isso não nos desobriga da tarefa de tentar uma classificação destes pontos de vista contraditórios, buscando delinear os campos de atração em que se agruparam as leituras desta cena tão importante no filme. Umas mais, outras menos, circunstanciadas, todas elas tentam decifrar o significado da troca do político pela cantora na representação do assassinato, lidando, cada uma a seu modo, com o fato de a narração não oferecer motivações dramáticas para a ação do personagem. 
Catherine Russell "resolve" este problema escapando para uma leitura "mítico-simbólica":

"A ação de Kenny é psicologicamente motivada pela erotização da figura materna de Barbara Jean, a ameaça edípica que a letra simplória de 'My Idaho Home' não consegue conter. Quando Barbara Jean é atingida, seu longo vestido branco é manchado com sangue, o que torna a cena ainda mais espetacular. Se a virgem e o cordeiro são sagrados precisamente por serem indefesos e incapazes de vingança, então a mancha vermelha sobre Barbara Jean é a marca da vítima sagrada."286

Outros autores constroem uma leitura simbólica mais firmemente sustentadas pelo filme, como é o caso de Alan Karp, para quem a psique em ruínas de Barbara Jean é um emblema "do mal-estar coletivo e da falta de integração social que fizeram dela aquilo que ela é" ${ }^{287}$, razão pela qual a comunidade representada por Kenny a ataca, em vez do político. Há também interpretações que ficam aquém do prometido, não por escapar demasiado da análise formal, mas, ao contrário, por serem reféns de um excessivo formalismo. Tal é o caso de Franck Kausch, cuja promessa de uma interessante leitura do assassinato como figuração do sentido histórico, da vida, se esboroa diante do ímpeto crítico que reconhece na cena uma simples repetição de um suposto traço estilístico da cinematografia de Altman; na leitura tautológica de Kausch, o filme termina em morte porque todo filme de Altman termina em morte:

"Todos os filmes de Altman terminam com uma morte e toda a meada de gestos e interpretações reunidos por sua dramaturgia é magnetizada por um sentimento de destruição, de retorno ao nada. [...]. Mas a realidade da morte só é perceptível através daquilo que a torna implacável e sempre iminente, ou seja, o tempo; em Altman, o desenrolar da existência temporal é ao mesmo tempo a prova e a necessidade da morte."288

Já a leitura de Daniel O’Brien é engessada por sua tentativa de desencavar uma progressão dramática inexistente no filme épico.

285 DEBORD, Guy. Comentários sobre a sociedade do espetáculo. in: A Sociedade do Espetáculo. p. 185.

${ }^{286}$ RUSSELL, Catherine. American Apocalypticism: the sight of the crisis. in: Narrative Mortality. p. 200.

${ }^{287}$ KARP, Alan. The Films of Robert Altman. p. 59. 
Assim, o crítico vai juntando os pontos de uma cadeia de relações causais que culmina no assassinato, apenas para se dar conta de sua inutilidade para uma explicação da cena:

"Esse final surpreendente, incluído por Altman contra a vontade de Tewkesbury, pode parecer abrupto e sem motivações, mas há um grande número de pistas plantadas em cenas anteriores. Quando vemos Barbara Jean pela primeira vez, ela está usando um vestido longo, parecido com a tradicional vestimenta de uma vítima sacrifical. Logo em seguida, ela desmaia, sublinhando, na aparência frágil de Ronee Blakley, o status de vítima de sua personagem. Há vários diálogos sobre assassinatos, especialmente o de Kennedy, acompanhados de teorias da conspiração. O próprio Kenny é uma das figuras mais marginalizadas no filme. Uma conversa telefônica revela uma relação complicada com sua mãe; fora isso, ele é caracterizado por sua aparência 'comum' (nem hippie nem 'bom moço') e pela caixa de seu instrumento, que permanece escondido até que o tiroteio comece. A recusa de Altman em fornecer uma motivação forte para a ação de Kenny (o diretor defende que o espectador é quem deve decidir por que o personagem mata Barbara Jean; não há uma explicação definida e definitiva) sublinha a natureza arbitrária da violência (Kenny queria acertar Haven também?) e a futilidade de se buscarem explicações." 289

Das leituras que insistem em uma interpretação, as mais interessantes são aquelas que veem nestas "pistas" lançadas ao longo do filme, não uma causalidade linear que explicaria este assassinato e este assassino especificamente, mas os passos da montagem de uma "estrutura metafórica, infranarrativa, que fornece o contexto para o tiroteio que conclui o filme." ${ }^{290}$ Parece ser este o ponto de vista adotado por Judith Kass, para quem

"O argumento de Altman ao longo do filme é que os tipos retirados do show business são indistinguíveis de nossos políticos (às vezes, eles são nossos políticos) - prometem o mesmo glamour, a mesma atmosfera de facilidade e sossego e são igualmente alvo para nossos tiros. $O$ assassinato de um pop singer promete o mesmo tipo de notoriedade barata que o de um Kennedy e apaga o mesmo tipo de dor, a dor de ver aqueles que têm, são e sempre serão mais do que tudo o que nós possamos sonhar em ter e ser."291

${ }^{288} \mathrm{KAUSCH}$, Franck. Altman et la mort: on achève bien les hommes. p. 97.

${ }^{289}$ O'BRIEN, Daniel. Robert Altman: Hollywood Survivor. p. $66-68$

${ }^{290}$ SELF, Robert T. Robert Altman's Subliminal Reality. p. 193.

${ }^{291}$ KASS, Judith M. Robert Altman: American innovator. p. 208. 
Finalmente, há os que defendem que não se deve tentar interpretar uma ação que, a despeito de quaisquer "pistas" que tenham sido lançadas, emerge como "ato arbitrário" e "caprichoso". Tal é o ponto de vista de Helene Keyssar e Jane Feuer. Para a primeira,

"Podemos nos distrair indefinidamente tentando juntar pistas que revelem a motivação de Kenny, propondo interpretações políticas, psicanalíticas e estéticas de sua ação e intenção. Entretanto, todas essas análises seriam insuficientes, não porque a evidência para elas é contraditória, mas porque a indagação sobre o quê, o porquê e o como apenas serve para nos distrair do fato de que Barbara Jean foi ferida. Altman recorda os erros de nossa história, mas não os repete. Ele se recusa a estender-se sobre Kenny; em vez disso, aponta sua câmera para o mundo abalado pelo ataque de Kenny."292

Feuer, por sua vez, entende que

"Em Nashville, a contradição entre complacência e violência é expressamente conectada à política dos anos 1970. Seria possível, mas enganoso, fornecer uma motivação para o assassinato. Um jovem chega à cidade com material de campanha de $\mathrm{Hal}$ Phillip Walker no banco de trás de seu carro. Pearl se perde em um discurso piegas sobre os 'Kennedy boys'. Opal expõe uma teoria sobre o assassinato político, dizendo que as pessoas que portam armas inspiram os assassinos e Altman corta para Kenny. Este jovem é caracterizado como tendo problemas com sua mãe; ele ouve Barbara Jean cantar sobre 'mamãe' e 'papai' e então atira em Barbara Jean. Todos estes fios percorrem a trama e podem ser conectados, mas a sua conexão nos desvia da questão principal. Este assassinato é necessariamente caprichoso; em um mundo onde a violência anda muito próxima da superfície da complacência, qualquer um poderia ser o assassino ou a vítima."293

Um traço comum a todas estas leituras é o fato de não considerarem o efeito que a substituição engenhosa do político pela cantora country tem sobre cada um destes críticos; tal reversão das expectativas narrativo-dramáticas transforma espectadores e críticos em "cientistas sociais", em "analistas da cultura" que, ao tentar explicar uma ação dramaticamente "não motivada", acabam por trazer à discussão um assunto em vias de naturalizar-se na vida cotidiana. Quer busquem uma solução psicanalítica, simbólica, mítica ou

292 KEYSSAR, Helene. Robert Altman's America. p. 171.

${ }^{293}$ FEUER, Jane. Nashville: Altman's open surface. Jump Cut, n. 10 (versão online). 
política para a cena inusitada, o que cada uma destes críticos acaba descobrindo é que representação não basta para explicar a cena; necessariamente, suas interpretações precisam remeter-se a um contexto mais amplo, fora da obra. Com isso, queremos argumentar que, mais do que propor uma determinada teoria do assassinato político, a cena final de Nashville visa a criar um "efeito de estranhamento", que "salva" o tema das "ações políticas violentas" do perigo da naturalização pelo senso comum e o renova como um objeto de indagação e crítica. Esta intenção de criar um "efeito de estranhamento" pode ser deduzida da própria recusa de Altman em inventar motivações para o ato de Kenny:

"Quem me pergunta por que ele matou a cantora em vez do político já obteve uma resposta no momento em que me perguntou, pois com isso quis dizer que um assassinato político é algo admissível, enquanto todo o resto parece sem sentido. Neste momento, nós temos três assassinos políticos encarcerados neste país; temos as habilidades técnicas e psiquiátricas para enviar um homem à Lua e dormir tranquilamente, sem nos preocupar se ele voltará ou não, pois sabemos que ele certamente voltará. E, mesmo assim, não há uma só pessoa na terra capaz de dizer por que estes homens cometeram estes três assassinatos."294

Altman não poderia ter sido mais claro sobre o porquê da troca do político pela cantora mais querida da cidade. Depois de mostrar que a violência faz parte do funcionamento normal das relações sociais em Nashville, terminar o filme com o assassinato de Walker não levantaria uma só pergunta sobre os "motivos" do assassino; afinal, diz a ideologia, "é da natureza" destes sujeitos agir sem uma lógica apreensível, assim como "é natural" que os políticos profissionais sejam seus alvos. Ao colocar Barbara Jean no lugar de Walker, Altman transforma o assassinato político em um objeto que não se encaixa em nossos esquemas engessados de leitura do mundo e da arte, fazendo surgir todo tipo de questionamento.

A "falha" que esta troca produz não é na forma narrativa do filme, mas sim na estrutura de sua recepção: fragmentam-se nossas 
crenças apaziguadoras em uma profusão de perguntas sem resposta; fragmentam-se o público e a crítica, em tentativas de interpretação das mais variadas, muitas vezes opostas. Portanto, aquilo que muitas vezes foi avaliado como "falta de talento" de Altman, um deus ex machina acionado para terminar um filme supostamente "ambíguo", é, na verdade,

"uma técnica de representação que permite retratar acontecimentos humanos e sociais, de maneira a serem considerados insólitos, necessitando de explicação, e não tidos como gratuitos ou meramente naturais. A finalidade deste efeito é fornecer ao espectador, situado de um ponto de vista social, a possibilidade de exercer uma crítica construtiva." 295

O efeito de estranhamento retira o espectador do estado de contemplação e o obriga a pensar como um "crítico cultural" ou um "cientista político"; ao mesmo tempo, na medida em que ele suspende a ação, do contínuo estritamente narrativo formado por uma cadeia de hipóteses e confirmações, ele relativiza a obra e impõe uma leitura alegórica, cujo quadro de referência é a História e não apenas a história. Fredric Jameson ratifica este parentesco entre o efeito de estranhamento brechtiano e os processos de alegorização da arte; ambos desafiam o conceito de autossuficiência da obra e a inserem num quadro mais amplo de discussões políticas, estéticas e sociais.

"Uma dada representação se torna alegórica na medida em que Ihe é retirada a autossuficiência do sentido. Essa retirada pode ser marcada por uma insuficiência radical da própria representação: espaços em branco, emblemas enigmáticos e coisas do tipo; porém, com maior frequência, particularmente nos tempos modernos, a alegoria toma a forma de uma pequena escora ou janela, por meio da qual a representação pode continuar a significar alguma coisa e parecer coerente. O teatro é, de novo, um espaço peculiarmente apropriado para mecanismos alegóricos, pois nele a autossuficiência da representação é sempre questionável; pouco importa o quão suntuosa e satisfatória é a aparência do espetáculo, no teatro sempre intervém a suspeita de operações miméticas, a incômoda sensação de que estes espetáculos imitam e, portanto, representam alguma outra coisa. Mesmo quando este representar, este 'estar no lugar de', é construído numa chave

${ }^{294}$ STERRITT, David (ed.). Robert Altman: interviews. p. 33. 
realista, um distanciamento alegórico, ainda que mínimo, é aberto nestas obras; uma abertura por meio da qual significados de todos os tipos se acumulam e vazam. A alegoria é, portanto, uma ferida reversa, uma ferida no texto; ela pode ser estancada ou controlada (especialmente por uma estética vigilantemente realista), mas a sua possibilidade nunca pode ser totalmente extinta." 296

Aberta esta "ferida" nas expectativas de recepção da cena, a leitura alegórica deve ser carregada para o restante da sequência, no qual, microfone à mão, Albuquerque começa a cantar os primeiros versos de "It Don't Worry Me". Trata-se de um sucesso da banda Bill, Mary e Tom que, até este ponto, havia sido tocado três vezes, de modo sempre incompleto: em registro "folk rock", na sequência do engarrafamento, em uma performance desajeitada de uma amadora no meio do circuito automobilístico, e cantada, a capela, pela plateia do Exit Inn. Inicialmente insegura, Albuquerque logo "se solta" e toma conta do palco:

“Dizem que este trem não dá carona, mas não estou nem aí.

E que o mundo inteiro está tomando partido, mas não estou nem aí.

Pois no meu império a vida é doce.

Pergunte a qualquer vagabundo que encontrar.

A vida pode ser uma rua de mão única, mas não estou nem aí.

Vamos lá, todo mundo, cantem!"

Segundo o relato de Jan Stuart, "It Don't Worry Me" foi uma das duas canções de Keith Carradine que Altman usou para convencer os produtores a financiarem Nashville. Trata-se, portanto, de uma canção que precede o filme, muito embora tenha servido aos objetivos da narração irônica em todos os momentos em que foi utilizada. Originalmente, ela havia sido

${ }^{295}$ BRECHT, Bertolt. Cena de Rua: Modelo de uma Cena de Teatro Épico. in: Teatro Dialético. p. 148.

${ }^{296}$ JAMESON, Fredric. Brecht and Method. p. 122. 
"escrita para Imperador do Norte [Emperor of the North, 1973], um filme de Robert Aldrich em que o ator [Keith Carradine] trabalhara ao lado de Lee Marvin e Ernest Borgnine. A canção, com sua melodia triste e sentimentalidade ao estilo de Woody Guthrie, se encaixava perfeitamente na fábula de Aldrich, sobre viagens clandestinas de trem, durante a Grande Depressão, mas o diretor optou pelo trabalho de Frank de Vol, um insosso compositor de Hollywood." 297

O filme de Aldrich aborda os deslocamentos de desempregados em busca de trabalho durante a Grande Depressão, viajando como clandestinos nos trens que cruzavam o país. Quando incorporados pela montagem de Nashville, os versos da canção originalmente elaborada para aquele filme tiveram seu sentido alterado; o "trem que não dá carona" já não pode mais ser lido ao pé da letra, pois agora ele figura todo um sistema político e econômico, que aliena aqueles que não podem pagar por seu acesso. Da mesma forma, o "não estou nem aí", que no original poderia indicar certa rebeldia em relação à ordem estabelecida, agora significa apenas a aceitação, aparentemente resignada, deste estado de alienação política e econômica.

O número de Albuquerque não é o primeiro a tematizar a apatia política; na primeira tomada diegética, o furgão de Walker já anunciava que, no momento em que até a compra de um automóvel é um ato político, abster-se deixou de ser uma opção. Em seguida, a narração mostrara, nos estúdios de gravação, como o trabalho na indústria cultural pode ser uma forma de exclusão; "seu lugar não é em Nashville", diz Haven a Frog, no momento em que o demite. Agora, no show "gratuito", oferecido às massas diante do Parthenon, a alienação política é, mais uma vez, associada à produção cultural. Se Walker, na sua conclamação às urnas, negava ao espectador o direito à abstenção, Albuquerque, ao pedir que "todos cantem", nega ao público o direito de não tomar parte no processo de esquecimento do assassinato de Barbara Jean.

${ }^{297}$ STUART, The Nashville Chronicles. p. 32. 
A apatia política das massas é socialmente produzida e, por paradoxal que pareça, é por meio dela, de sua incorporação funcional, que essas massas se envolvem, definitivamente, no processo político. Neste sentido, o cinismo dos versos de "It Don't Worry Me" pode ser visto como uma denúncia daquela fala de Walker como uma violência política, assim como a exposição do

"sentimento, de nenhum modo injustificado das massas, de que, com a margem de participação na política que lhes é reservada pela sociedade, pouco podem mudar em sua existência, bem como, talvez, em todos os sistemas da terra atualmente. O nexo entre a política e os seus próprios interesses lhes é opaco, por isso recuam diante da atividade política. Em íntima relação com o tédio está o sentimento, justificado ou neurótico, de impotência: tédio é o desespero objetivo. Mas, ao mesmo tempo, também a expressão de deformações que a constituição global da sociedade produz nas pessoas."298

Na performance de Albuquerque, confirma-se o horror da união entre política e indústria cultural: na vida administrada, o "tempo livre" é extensão do tempo de trabalho e não se pode escapar da estrutura econômica que dominou o primeiro nem do aparato cultural que tomou conta do segundo; Walker negava o direito à apatia política dizendo, justamente, que estamos todos envolvidos em política, pela mediação do sistema econômico; celebrando sua apatia, a personagem excluída do sistema econômico-cultural responde à fala do político.

Enquanto isso, a cena fragmentada vai-se recompondo por meio da canção. Relações rompidas se reconstroem; Bill agarra Mary, sua esposa, abandonando Martha, que é encontrada por Mr. Green; Del retira Linnea do palco; o coral negro, que esperava para apresentar-se ao lado dela, se junta a Albuquerque, cantando o estribilho e marcando o ritmo com palmas: "Não estou nem aí, não estou nem aí. Podem dizer que não sou livre, mas não estou nem aí." Outras personagens ficam "perdidas" no meio da confusão: Opal, como sempre, tinha seu olhar concentrado em algo de menor

${ }^{298}$ ADORNO, Theodor W. Tempo Livre. in: Indústria Cultural e Sociedade. p. $109-110$. 
importância, deixando de testemunhar um acontecimento-chave para seu documentário; "O que aconteceu? Alguém pode me dizer o que aconteceu?", pergunta insistentemente, sublinhando a rapidez com que o evento traumático já foi removido da consciência social. "Petrificada" junto a uma coluna, Sueleen parece refletir sobre o quão irônica se tornou a previsão de Wade, na noite anterior: "Eles vão te matar nessa cidade, menina". Desolado, Triplette deixa o palco, enquanto o soldado Kelly olha, perplexo, para o espaço onde, minutos antes, cantava o seu ídolo musical.

Os últimos traços de Barbara Jean são apagados conforme Albuquerque recolhe do chão as rosas brancas pisoteadas que haviam sido oferecidas à cantora e as atira ao público. No gesto de remover os vestígios do assassinato, a atriz encena o apagamento da consciência histórica por meio da música, algo que, até aqui, havia sido sugerido, por exemplo, na expressão perdida do soldado Kelly no Opry Belle, ao mesmo tempo fascinado pela canção de Barbara Jean e tomado por uma espécie de amnésia de sua passagem pelo Vietnã. Conforme o canto de Albuquerque unifica a todos em um só sentimento de celebração e esquecimento, o virtuosismo de sua performance surpreende, sobretudo porque, dado o seu nível de desvalimento social, esperávamos que fosse tão despreparada quanto Sueleen. Não é o que se vê; de fato, o registro blues em que ela canta supera o de vários stars estabelecidos na cidade:

“O preço do pão pode preocupar a muitos, mas não a mim.

Isenção fiscal, talvez nunca aconteça, mas não estou nem aí.

A economia está deprimida; eu não.

Meu astral não poderia estar mais alto.

Podem dizer que não sou livre, mas não estou nem aí. ${ }^{299}$

299 "They say this train don't give out rides, but it don't worry me./ And all the world is taking sides, but it don't worry me./ 'Cause in my empire life is sweet/ Just ask any bum you meet./ Life may be a one-way street, but it don't worry me./ It don't worry me, it don't worry me./ You may say that I ain't free,/ But it don't worry me./ The price of bread may worry some, but it don't worry me./ Tax 
A imagem dialética surgida da contradição entre 0 desvalimento social de Albuquerque e seu domínio do palco suscita uma série de perguntas que, mais uma vez, desautoriza uma leitura rígida, definitiva, de qualquer cena no filme. Como pode surgir uma cantora com o vigor e a técnica de Albuquerque em um sistema político e econômico que reprime, desmobiliza e destrói formas de cultura popular? Com quem Albuquerque aprendeu a cantar? Quem lhe ensinou o domínio do palco? Se o número que ela canta promove a reunificação espetacular da plateia, ele também tem algo de antiespetacular: sendo melhor do que Haven, Albuquerque dá notícia do despreparo do cantor autoritário; cantando a letra regressiva em um registro blues, ela produz apaziguamento, mas também sublinha contradições. Talvez, correndo o risco de "esticar" o argumento, seja possível dizer que essas perguntas sobre as condições de possibilidade de uma cantora como Albuquerque, dentro das condições de produção delineadas no filme, lançam um questionamento parecido sobre a viabilidade de um cinema como o de Altman, dentro do esquema hollywoodiano de produção. Tanto a cantora, cuja performance desmascara a artificialidade do "olimpo" de Nashville, quanto o cineasta, cujo nível de realização artística põe em dúvida a qualidade da cinematografia norteamericana produzida a partir dos anos 1970, desautorizam uma visão estreita das indústrias culturais nos EUA e convidam à reflexão sobre as possibilidades de resistência dentro do aparato opressivo.

Michael Klein também enfatiza a necessidade de não se fazer uma leitura unilateral da performance de Albuquerque, lembrando que, diferente de outros números musicais, "It Don’t Worry Me"

"é cantada, com páthos, em um estilo blues; não se trata apenas de uma tentativa de esquecer e escapar do sofrimento e da dor, mas também um reconhecimento triste de que esta dor e este sofrimento são sociais. Conforme a plateia se junta à música, uma fonte poderosa de energia é revelada, em contraposição às palavras na superfície da canção. Há a possibilidade de que as esperanças, os ideais e os recursos do povo,

relief may never come, but it don't worry me./ Economy's depressed, not me./ My spirit's high as it can be./ You may say that I ain't free, but it don't worry me." 
que estão sendo corrompidos pela sociedade contemporânea, funcionem também como um prenúncio do futuro. O que o filme nos deixa é uma imagem da contradição, assim como um sentimento renovado de que as necessidades do povo só poderão ser efetivamente satisfeitas por meio da negação de um sistema social que, nas palavras de Marx, 'pulverizou' as relações e os valores humanos." 300

A leitura de Klein, entretanto, vai na contramão de boa parte da fortuna crítica, incluindo aqueles que reconheceram os méritos no filme. Tal é o caso, por exemplo, da avaliação de Robin Wood:

"O efeito total do filme - apesar de alguns maravilhosos achados localizados - é agarrar o espectador no movimento de desintegração que retrata, tornando impossível qualquer distanciamento intelectual. A força irônica do final, com a multidão confrontando a catástrofe, com 'It Don't Worry Me', uma recusa coletiva ao pensamento, é enfraquecida por uma inabilidade do diretor em oferecer qualquer alternativa construtiva, mas também por uma rejeição generalizada a qualquer possibilidade de alternativa. [Nashville é] um filme que [...] me deixou um sentimento de enjoo e depressão, apesar de toda a minha admiração por seu alcance e audácia."301

Ambas as leituras são respaldadas pelo filme, o que prova, mais uma vez, sua capacidade de fragmentar o público em recepções muitas vezes opostas. A este respeito, pense-se, por exemplo, na "análise da plateia" feita a partir de uma série de close-ups, por meio dos quais o "olhar da câmera" vai "catando", alternadamente, rostos no meio da multidão - mulher, homem, menininha, menininho, adolescente, outra mulher, bebê, menina, mulher, etc. - acompanhando o estribilho ("Não estou nem aí, não estou nem aí...") repetido, indefinidamente, fora do campo. A sequência de montagem, captada com total liberdade pelo operador de câmera, é essencialmente contraditória; nos rostos animados das crianças, inocentemente aplaudindo e cantando o refrão com sentido político, é possível ler tanto o "prenúncio do futuro", de que fala Michael Klein, quanto uma imagem da infantilização das massas, o "movimento de desintegração", mencionado por Robin Wood.

\footnotetext{
${ }^{300}$ KLEIN, Michael. Nashville and the American dream. Jump Cut, n. 9. (versão online).

${ }^{301}$ WOOD, Robin. Smart-Ass and Cutie-Pie: Notes Toward the Evaluation of Altman (1975). in: Hollywood from Vietnam to Reagan...and Beyond. p. 37.
} 
Enquanto a plateia canta, Albuquerque adiciona a seus versos palavras de encorajamento e pacificação: "Se não vivermos pacificamente, não sobrará nada de nós a não ser frascos de Clorox e matamoscas de plástico, com pontinhos vermelhos." A referência às mercadorias populares retoma partes do monólogo improvisado pela atriz, na sequência do engarrafamento, em que ela afirmava não entender bem como se fica rico vendendo "mata-moscas", embora suspeitasse que tudo "tem a ver com a revolução industrial". Corte para um plano frontal do palco, na mesma escala daquele que nos apresentou a queda de Barbara Jean. Albuquerque percorre toda a linha horizontal sugerida pelo tablado, removendo as últimas flores pisoteadas e indicando, na repetição ad nauseam do estribilho aborrecido, que "o show deve continuar". O "término" do filme com uma "canção interminável" é mais uma peça lançada para a compreensão do papel desempenhado pela música na sustentação das relações humanas representadas:

"Enquanto alguns personagens estão mais integrados do que outros, todos estão subordinados à música. Esta funciona como um rio correndo ao longo do filme e de suas vidas. Eles contribuem para ela, unem-se a ela por algum tempo, são atirados para fora dela, morrem, mas a música, como a última cena sugere, continua.”302

Jane Feuer fez uma leitura ainda mais interessante sobre a persistência de "It Don't Worry Me", inclusive para além do universo ficcional, sobrepondo-se aos créditos e, finalmente, à tela escura. A autora suspeita que, ao repetir, insistentemente, o estribilho de "It Don't Worry Me", Altman queria

"que o público saísse da sala de cinema cantando aquela canção. Este público se torna parte da multidão no Parthenon e, dependendo de como percebemos o filme, somos atacados ou implicados na sua visão de mundo. [...] O drama da sequência final de Nashville não acaba quando as luzes da sala de cinema se acendem.”303

302 HASKELL, Molly. apud KAGAN, Norman. American Skeptic: Robert Altman's GenreCommentary Films. p. 141.

${ }^{303}$ FEUER, Jane. Nashville: Altman's open surface. Jump Cut, n. 10 (versão online). 
Ao expor aquilo que chama de "estrutura aberta" de Nashville, Feuer indiretamente nos revela o modo como o filme supera a distância entre a representação cinematográfica e o público; ao reconhecer-se nas representações fílmicas da plateia, o público de cinema deve sentir-se, alternadamente, atacado, distanciado e implicado na obra. Além disso, é preciso lembrar que o artigo de Feuer é de 1976, de modo que seu comentário a respeito de sair da sala de cinema cantando o estribilho de "It Don't Worry Me" tem o valor de depoimento, em primeira mão, sobre a recepção do filme. Se o filme conseguia realizar o que diz Feuer - fazer os espectadores cantarem a música, ao mesmo tempo em que questionavam suas próprias implicações na história - então ele satisfez um requisito básico da representação épica, a saber: o encorajamento de uma fruição crítica da obra de arte.

"Sufocado" pelo esquecimento coletivo do assassinato político, o "olhar da câmera" distancia-se, em zoom-out, até que já não se podem discernir figuras individuais no palco, mas apenas os slogans de campanha sob a bandeira nacional, a colunata do Parthenon ao fundo e o público transformado em uma massa homogênea. Em um movimento panorâmico no eixo horizontal, o "olhar narrador" busca um escape no céu de Nashville, onde, porém, ele só encontra nuvens carregadas. Em fade-out, o estribilho interminável desaparece, junto com a imagem.

Nesta última tomada diegética, a narração demonstra sua capacidade de manter a representação tensionada até o final. Conforme a personagem diz suas falas de apaziguamento, ela aparece como figura protofascista. Pressionada pelo aparato espetacular, Albuquerque dominou a si mesma e à plateia. $\mathrm{O}$ "processo de seleção" pelo qual ela passou é o mesmo "do qual emergem, como vencedores, o campeão, o astro e o ditador." ${ }^{304}$ Por outro lado, ao distanciar-se da personagem até que sua figura não possa ser separada da massa, o "olhar narrador" relativiza sua vitória diante do aparato e

304 BENJAMIN, Walter. A obra de arte na era de sua reprodutibilidade técnica. in: Magia e Técnica, Arte e Política. p. 183. 
inverte o processo de singularização do qual ela emergiu como star. A tomada do céu, com nuvens carregadas, é, ao mesmo tempo, uma imagem de escapismo e um convite à imaginação.

Como um último comentário sobre o aproveitamento artístico que Altman faz do aparato técnico hollywoodiano, é preciso tratar do formato de tela Panavision em que Nashville foi filmado e de seu uso expressivo, principalmente neste último plano-sequência. Como lembra Richard T. Jameson,

"Raramente o formato Panavision foi tão utilizado para tratar de materiais dinamicamente enquadráveis como [em Nashville]. Altman se mostra apaixonado por aviões, limusines, autoestradas, camas, balcões de lanchonetes, corredores, grupos de Tennessee Twirlers, a cortina e o palco do Grand Ole Opry, o Parthenon, o título 'Nashville' em letras garrafais, um longo triciclo inclinado saído daquele filme, Easy Rider.”305

Na sequência final, a tendência à horizontalidade da composição visual, sugerida pelo formato widescreen Panavision, se multiplica em figuras que se estendem lateralmente, aumentando o campo de visão do espectador: as listras da bandeira norte-americana em plano grande, o palco montado no Centennial Park, o enorme letreiro com o slogan de campanha, o teto sobre a colunata infindável do Parthenon, as escadarias mais abaixo, as vias transversais nas alamedas do parque, a multidão tomada em plano geral e, concluindo o conjunto, os créditos finais, exibidos em fonte miúda, alargada nas laterais. Com o formato Panavision, combinado a movimentos panorâmicos, Altman encontrou uma solução técnica que lhe permitiu incorporar um grande número de atores no processo de trabalho, sem prejudicar a unidade da composição; tratou-se, apenas, de "colocar as pessoas na tela e deixar que o espectador tentasse impor o seu próprio foco na cena." ${ }^{306} \mathrm{Ou}$ seja, no cinema de Altman, o formato Panavision funciona com um complemento visual da trilha sonora densa; ambos os recursos de composição destinam-se a multiplicar os objetos de atenção do espectador, lançando para ele a tarefa de discriminar

305 JAMESON, Richard T. Nashville: Writin' it down kinda makes me feel better. p. 9.

${ }^{306}$ Ibid., p. 10. 
pontos de interesse no material que the é oferecido. Trata-se de um aproveitamento crítico de um recurso técnico que influenciara, diretamente, a consolidação da estética do plano-sequência no cinema moderno e o concomitante abandono da montagem dialética, baseada no corte rápido e ritmado, com todos os prejuízos daí decorrentes. Como nos ensina David Cook,

"o widescreen encorajou o uso de tomadas mais longas do que o normal e hoje parece mais claro que os processos widescreen criaram a base funcional para uma nova estética fílmica, baseada na composição em largura e profundidade, ou mise-enscène, em vez da montagem. Nesta nova estética, que pode ser chamada de estética do planosequência ou da mise-en-scène, o trabalho criativo seria deslocado da montagem para a filmagem, pois o plano longo, composto em largura e profundidade, é capaz de conter um plano geral, um plano médio e um close-up, em um único quadro, tornando desnecessária a fragmentação da imagem.",307

Em Nashville, o plano-sequência nunca ocupa esta posição central na composição, mesmo nas cenas que exigiram um trabalho mais cuidadoso de mise-en-scène. Tome-se, por exemplo, a sequência do engarrafamento, de que tratamos anteriormente: nela, a amplitude do formato Panavision foi utilizada para captar, ao mesmo tempo, vários fragmentos improvisados; porém, a possibilidade do uso de outros recursos técnicos, tais como a captação individualizada de fontes de som, diminuiu a rigidez da miseen-scène, pois eventuais diálogos não aproveitáveis podiam ser eliminados no processo de mixagem, deixando apenas a sua imagem na tela. Com isso, Altman liberou a criação coletiva durante as filmagens, implodindo a rigidez do plano-sequência e resguardando para si a possibilidade de intervir criativamente no material filmado, por meio da montagem entre som e imagem.

Ao fazer da última tomada diegética de Nashville um plano-sequência "interminável", do qual o "olhar da câmera" só escapa desviando-se do assunto para um céu carregado, Altman faz um derradeiro comentário autorreferencial, lançando uma dúvida sobre os méritos da estética dominante no cinema moderno norte-americano. Ao colocar tal estética a serviço 
da montagem, Altman dá provas de que a condição para um cinema épicodialético nas condições de produção norte-americanas é um esforço de apropriação das técnicas disponíveis e de sua refuncionalização no sentido de um uso crítico. A representação épica é o que resulta dessa reapropriação de recursos formais e técnicos; o esforço épico, concebido como uma forma de organizar os artistas no processo de trabalho, é a estratégia política que a viabiliza.

"It Don’t Worry Me", "canção símbolo" de Nashville, ganha mais uma versão durante a exibição dos créditos finais. Sobem na tela os nomes dos atores em fonte branca, justapostos a suas respectivas personagens, em letras vermelhas, com uma estrela azul no meio, recuperando os elementos básicos da composição cromática. Finalmente, atando as últimas pontas do filme, o estribilho interminável ("Podem dizer que não sou livre, mas não estou nem aí') é exibido sobre a tela escura.

${ }^{307}$ COOK, David. A History of Narrative Film. p. 475 - 476. 


\section{Bibliografia}

\section{Fortuna Crítica}

ABRAHAMS, Steven. Buying Nashville. Jump Cut, n. 9, 1975, p. 6 - 7. disponível em http://www.ejumpcut.org/archive/onlinessays/JC09folder/NashvilleAbraham s.html consultado em 20/12/2012

ALEIXO, A. M. Reflexões sobre a configuração do espaço fílmico em Nashville. Revista CROP, São Paulo, n. 13, p. 139 - 152, 2008.

ALPERT, Hollis. The homecoming of Barbara Jean. Saturday Review, n. 2, 28/06/1975, p. $40-41$.

ALTMAN, Rick. 24-track narrative? Robert Altman's Nashville. Cinémas: revue d'études cinématographiques. Vol. 1 no 3, nov. 2000. Disponível em: http://www.revue-cinemas.info/revue/revue\%20no3/08-altman.htm (consultado em 19/07/2012)

ALTMAN, Rick. The American Film Musical. Bloomington (USA): Indiana University Press, 1987.

AMANCIO, Tunico. Nashville e os por quês. As Muitas Vidas de Robert Altman. Rio de Janeiro, São Paulo e Brasília: Centro Cultural Banco do Brasil, s.d. p. 133 - 135. (Catálogo da mostra As Muitas Vidas de Robert Altman 2008)

ARMSTRONG, Rick (org.). Robert Altman: critical essays. Jefferson: McFarland \& Company, 2011.

BERTHOMIEU, Pierre. Robert Altman et le zoom: entre peinture, musique et photographie. Positif, n. 564, fev. 2008, p. $94-96$.

BOURGET, Jean-Loup. Robert Altman. Paris: Edilig, 1980. (Cinématographiques) 
BOWLES, Stephen E. Cabaret and Nashville: the musical as social comment. The Journal of Popular Culture, n. 12, v. 3, 1978, p. $550-556$

BRANCO, Neyde F. O Poder Vai Dançar de Tim Robbins: História, Avanços e Limites, 2011. Dissertação (Mestrado em Estudos Linguísticos e Literários em Inglês) Universidade de São Paulo. São Paulo.

CAETANO, Daniel. Circo dos sonhos. As Muitas Vidas de Robert Altman. Rio de Janeiro, São Paulo e Brasília: Centro Cultural Banco do Brasil, s.d. p. 92 93 (Catálogo da mostra As Muitas Vidas de Robert Altman - 2008)

CHURNER, Leah. Big Auto Dynamite. Reverse Shot (Online), n. 27. Disponível em: www. Reverseshot.com/article/nashville consultado em 02/08/2010.

DIRKS, Tim. Nashville (1975). Filmsite. Disponível em: http://www.filmsite.org/nash.html, consultado em: 30/06/2007

ELSAESSER, Thomas. Où finit le spectacle?... (à propos de "Nashville"). Positif, n. 197 , set. 1977 , p. $23-27$.

ELSAESSER, Thomas; HORWATH, Alexander \& KING, Noel (eds.). The Last Great American Picture Show: New Hollywood cinema in the 1970s. Amsterdam: Amsterdam University Press, 2004.

FEUER, Jane. Nashville: Altman's open surface. Jump Cut, n. 10 - 11, 1976, disponível em: http://www.ejumpcut.org/archive/onlinessays/JC1011 folder/NashvilleFeuer.html, consultado em: 20/12/2012.

GARDNER, Paul. Altman Surveys "Nashville" and Sees "Instant" America. New York Times, 13 de junho de 1975, p. 26.

GILBEY, Ryan. It Don't Worry Me: the revolutionary American films of the seventies. New York: Faber and Faber, 2003.

GROSSI, Solange de Almeida. Short Cuts de Robert Altman: atalhos para as formas de ilusão contemporâneas. São Paulo: Humanitas, 2010.

HARRY, Lou. Nashville. Gadfly, Charlotsville (USA), n. 6 v. 4, nov.-dez. 2000 p. $36-38$. 
HENRY, Michael. Altmanscope (sur le plateau de "Nashville"). Positif, n. 177, jan/1976. p. $10-26$.

HENRY, Michael. Entretien avec Robert Altman: Tout est spectacle. Positif, n. 550, dez/2006. p. $21-23$.

JAMESON, Richard T. Nashville: Writin' it down kinda makes me feel better. Movietone News, Seattle, n. 43, set. 1975. p. 1 - 24.

KAEL, Pauline. Reeling: film writings, 1972 - 1975. London, Marion Boyars, 1992.

KAGAN, Norman. American Skeptic: Robert Altman's Genre-Commentary Films. Ann Arbor (USA): The Pierian Press, 1982.

KARP, Alan. The Films of Robert Altman. Metuchen (USA): The Scarecrow Press, 1981.

KASS, Judith M. Robert Altman: American innovator. New York: Popular Library, 1978.

KAUSCH, Franck. Le crépuscule des idoles: à propôs de Robert Altman. Positif, n. 550, dez/2006. p. $17-19$.

KAUSCH, Franck. Altman et la mort: on achève bien les hommes. Positif, n. 562, dez. 2007. p. $96-98$.

KEYSSAR, Helene. Robert Altman's America. New York: Oxford University Press, 1991.

KLEIN, Michael. Nashville and the American dream. Jump Cut, n. 9, 1975, p. 6 7. Disponível

em: http://www.ejumpcut.org/archive/onlinessays/JC09folder/NashvilleKlein.html Consultado em: 20/12/2012

KOLKER, Robert. A Cinema of Loneliness: Penn, Stone, Kubrick, Scorsese, Spielberg, Altman. $3^{\underline{a}}$ ed. New York: Oxford University Press, 2000.

LEV, Peter. American Films of the 70s: conflicting visions. Austin: University of Texas Press, 2000. 
LOBIANCO, Lorraine. Nashville. Disponível em: http://www.tcm.com/thismonth/article/115792\%7C0/Nashville.html, consultado em: 25/12/2012.

LoBRUTTO, Vincent (ed.). Sound-on-Film: interviews with creators of film sound. Westport (USA): Praeger, 1994.

MCGILLIAN, Patrick. Robert Altman: jumping off the cliff. New York: St. Martin's Press, 1989.

MICHENER, Charles \& DORF, Martin K. Altman's Opryland Epic. Newsweek, n. 85,30 de junho de 1975. p. $46-50$.

O'BRIEN, Daniel. Robert Altman: Hollywood Survivor. New York: Continuum, 1995.

O'NEILL, Eithne. The Last Show: Asphodèle ou la nostalgie post-moderne. Positif, n. 550, dez/2006. p. $15-16$.

PECKNOLD, Diane. The Selling Sound: the rise of the country music industry. Durham: Duke University Press, 2007.

PLECKI, Gerard. Robert Altman. Barcelona: Editorial Lerna, 1985. (Colección Ordet) p. 129.

ROSA, Joyce. A Espetacularização da Política em Bob Roberts, 2010. Dissertação (Mestrado em Estudos Linguísticos e Literários em Inglês) Universidade de São Paulo. São Paulo.

ROSENBAUM, Jonathan. Essential Cinema: on the necessity of film canons. Baltimore (USA): The John Hopkins University Press, 2004.

RUSSELL, Catherine. Narrative Mortality: Death, Closure and New Wave Cinemas. Minneapolis: University of Minnesota Press, 1995.

SAWHILL, Ray. A movie called "Nashville". Salon.com, 27 de junho de 2000. disponível em: http://archive.salon.com/ent/movies/feature/2000/06/27/nashville/index.html, consultado em: 30/06/2007. 
SELF, Robert T. Robert Altman's Subliminal Reality. Minneapolis: University of Minnesota Press, 2002.

SOARES, Marcos. Estética e Política em Robert Altman. Revista Nau, São Paulo, v. 1, n. 1, jan./jun. 2008, p. $95-105$.

STERRITT, David (ed.). Robert Altman: interviews. s.I.: University Press of Mississippi, 2000.

STUART, Jan. The Nashville Chronicles: the making of Robert Altman's masterpiece. New York: Limelight Editions, 2003.

TANAKA, Elder K. I. Jazz, indústria cultural e política em Kansas City, de Robert Altman, 2010. Dissertação (Mestrado em Estudos Linguísticos e Literários em Inglês) Universidade de São Paulo. São Paulo.

TEWKESBURY, Joan. Nashville. New York: Bantam, 1976.

THOMPSON, David. Altman's astonishing decade. New York Times, 11 de junho de 2000. Disponível em: www.nytimes.com/library/film/061100altmanfilms.html, consultado em: 01/01/2013

TROVÃO, Flávio Vilas-Bôas. O Exército Inútil de Robert Altman: cinema e política. São Paulo: Anadarco Editora, 2012.

WOOD, Robin. Hollywood from Vietnam to Reagan...and Beyond. New York: Columbia University Press, 2003.

YATES, John. Smart Man's Burden: Nashville, A Face in the Crow, and Popular Culture. The Journal of Popular Film, Bowling Green (USA), v. 5, n. 1, 1976. p. $19-27$.

ZUCKOFF, Mitchell. Robert Altman: the oral biography. New York: Alfred A. Knopf, 2009. 


\section{$\underline{\text { Referências Gerais }}$}

ADORNO, Theodor W. Indústria Cultural e Sociedade. 3aㅗ ed. São Paulo: Paz e Terra, 2002. (Coleção Leitura)

ADORNO, Theodor W. Teoria Estética. Trad. Artur Morão. Lisboa: Edições 70, 2006.

ADORNO, Theodor W., BENJAMIN, Walter et. al. Textos Escolhidos. Trad. José Lino Grunnewald et al. São Paulo: Abril Cultural, 1980. (Os Pensadores).

ADORNO, Theodor W. \& EISLER, Hanns. Composing for the Films. London: Continuum, 2007.

ADORNO, Theodor W. \& HORKHEIMER, Max. Dialética do esclarecimento: fragmentos filosóficos. Trad. Guido Antonio de Almeida. Rio de Janeiro: Jorge Zahar Ed., 1985.

American Genealogical Research Institute. The Green Family. Arlington (EUA): AGRI, 1972.

ANTUNES, Ricardo L. C. O Caracol e sua Concha: ensaios sobre a nova morfologia do trabalho. São Paulo: Boitempo, 2005. (Mundo do Trabalho)

ARONOWITZ, Stanley. From the Ashes of the Old: American Labor and America's Future. Boston: Houghton Mifflin Company, 1998.

BAKHTIN, Mikhail. Marxismo e Filosofia da Linguagem: problemas fundamentais do método sociológico na ciência da linguagem. $12^{\mathrm{a}} \mathrm{ed}$. Trad. Michel Lahud e Yara Frateschi Vieira. São Paulo: Hucitec, 2006.

BENJAMIN, Walter. Charles Baudelaire: um lírico no auge do capitalismo. Trad. José Martins Barbosa et al. $3^{\underline{a}}$ ed. São Paulo: Brasiliense, 1994. (Obras Escolhidas, v. 3)

BENJAMIN, Walter. Magia e Técnica, Arte e Política: ensaios sobre literatura e história da cultura. Trad. Sérgio Paulo Rouanet. $7^{\text {a }}$ ed. São Paulo: Brasiliense, 1994. (Obras Escolhidas, v. 1) 
BERMAN, Marshall. Tudo Que é Sólido Desmancha no Ar. Trad. Carlos Felipe Moisés et al. São Paulo: Companhia das Letras, 2007.

BERNARDET, Jean-Claude. O Que é Cinema. 1a ed. São Paulo: Brasiliense, 1980. (Coleção Primeiros Passos; v. 9)

BODNAR, John. Blue-collar Hollywood: liberalism, democracy and working people in American film. Baltimore/London: The John Hopkins University Press, 2006.

BOORSTIN, Daniel J. The Image: a guide to pseudo-events in America. New York: Vintage Books Editions, 1992.

BORDWELL, David. Narration in the Fiction Film. Madison (EUA): The University of Wisconsin Press, 1985.

BORNHEIM, Gerd. Brecht: a estética do teatro. Rio de Janeiro: Graal, 1992.

BRAVERMAN, Harry. Labor and Monopoly Capital: the degradation of work in the twentieth century. New York: Monthly Review Press, 1974.

BRECHT, Bertolt. Estudos Sobre Teatro. Trad. Fiama Pais Brandão. Rio de Janeiro: Nova Fronteira, 1978.

BRECHT, Bertolt. Teatro Dialético. Rio de Janeiro: Civilização Brasileira, 1967.

BROE, Dennis. Film Noir, American Workers, and Postwar Hollywood. Gainesville (EUA): University Press of Florida, 2009.

BROSSES, Charles de. Du Culte des Dieux Fétiches, ou Parallèle de l'Anciène Religion de l'Egypte avec la Religion Actuelle de Nigritie. s.I.: Fayard, 1988. (Corpus des Oeuvres de Philosophie en Langue Française)

BUCCI, Eugênio \& KEHL, Maria Rita. Videologias: ensaios sobre televisão. São Paulo: Boitempo, 2004. (Estado de Sítio)

BURCH, Noel. Práxis do Cinema. Trad. Marcelle Pithon, Regina Machado. São Paulo: Perspectiva, 2006. (Debates; 149) 
CANDIDO, Antonio. O Discurso e a Cidade. $3^{\text {a }}$ ed. São Paulo - Rio de Janeiro: Duas Cidades - Ouro Sobre Azul, 2004.

CARVALHO, Sérgio de (org.). Introdução ao Teatro Dialético: experimentos da Companhia do Latão. São Paulo: Editora Expressão Popular, 2009.

CEVASCO, Maria Elisa. Para Ler Raymond Williams. São Paulo: Paz e Terra, 2001.

CEVASCO, Maria Elisa \& OHATA, Milton (org.). Um Crítico na Periferia do Capitalismo: reflexões sobre a obra de Roberto Schwarz. São Paulo: Companhia das Letras, 2007.

CHATMAN, Seymour. Story and Discourse: narrative structure in fiction and film. Ithaca (EUA): Cornell University Press, 1980.

CHAUI, Marilena. Convite à Filosofia. 13를. edão Paulo: Ática, 2005.

CHAUI, Marilena. O que é Ideologia. $2^{\mathrm{a}}$ ed. São Paulo: Brasiliense, 2006.

CHION, Michel. Audio-Vision: sound on screen. Ed. e trad. por Claudia Gorbman. New York: Columbia University Press, 1994.

CHION, Michel. The Voice in Cinema. Ed. e trad. por Claudia Gorbman. New York: Columbia University Press, 1999.

COOK, David A. A History of Narrative Film. $3^{\underline{a}}$ ed. New York: W. W. Norton, 1996.

COOK, David A. Lost Illusions: American cinema in the shadow of Watergate and Vietnam, 1970 - 1979. Berkeley: University of California Press, 2002. (History of the American Cinema, v. 9)

COSTA, Iná C. Brecht e o Teatro Épico. Disponível em: http://www.teatrocoletivo.com.br/index.php?option=com_remository\&ltemid $=57 \&$ func $=$ startdown\&id=12. Consultado em 12/11/2012.

COSTA, Iná C. "Contra o Drama”. Palestra apresentada no Núcleo 2 Cia Fábrica São Paulo, em 12/09/2005. Disponível em: 
http://www.teatrocoletivo.com.br/index.php?option=com_remository\&Itemid =57\&func=startdown\&id=13 Consultado em 12 de novembro de 2012.

COSTA, Iná C. Panorama do Rio Vermelho: ensaios sobre o teatro americano moderno. São Paulo: Nankin Editorial, 2001.

CROSS, Gary S. An All-consuming Century: why commercialism won in modern America. New York: Columbia University Press, 2000.

DAVIS, Mike. Prisoners of the American Dream: politics and economy in the history of the U.S. working class. New York: Verso, 1986.

DEBORD, Guy. A Sociedade do Espetáculo. Trad. Estela dos Santos Abreu. Rio de Janeiro: Contraponto, 1997.

DENNING, Michael. The Cultural Front: the laboring of American culture in the twentieth century. London: Verso, 1997.

DOCTOROW, E. L. Ragtime. New York: Plume, 1974.

DOS PASSOS, John. U.S.A. New York: The Library of America, 1996.

EISENSTEIN, Sergei. A Forma do Filme. Trad. Teresa Ottoni. Rio de Janeiro: Jorge Zahar Ed., 2002.

FINLAYSON, James G. The Artwork and the Promesse du Bonheur in Adorno. Disponível em: http://jamesgordonfinlayson.net/the-artwork-and-thepromesse-du-bonheur-in-adorno/\#_edn1; Consultado em 06/12/2012.

FONTENELLE, Isleide A. O Nome da Marca: McDonald's, fetichismo e cultura descartável. São Paulo: Boitempo Editorial, 2002.

FRANK, Thomas. The Conquest of Cool: business culture, counterculture, and the rise of hip consumerism. Chicago: The University of Chicago Press, 1997.

FRANK, Thomas. What's the Matter with Kansas? How conservatives won the heart of America. 1르 ed. New York: Metropolitan Books, 2004. 
FREUD, Sigmund. Além do Princípio de Prazer, Psicologia de Grupo e Outros Trabalhos (1920 - 1922). Rio de Janeiro: Imago, 1996. (Edição Standard Brasileira das Obras Psicológicas de Freud; v. XVIII)

FREUD, Sigmund. O Caso Schreber, Artigos sobre Técnica e Outros Trabalhos (1911 - 193). Rio de Janeiro: Imago, 1996. (Edição Standard Brasileira das Obras Psicológicas de Freud; v. XII)

FREUD, Sigmund. Os Chistes e a Sua Relação com o Inconsciente (1905). Rio de Janeiro: Imago, 1996. (Edição Standard Brasileira das Obras Psicológicas Completas de Freud; v. VIII)

FREUD, Sigmund. O Futuro de Uma Ilusão, O Mal-Estar na Civilização e outros trabalhos (1927 - 1931). Rio de Janeiro: Imago, 1996. (Edição Standard Brasileira das Obras Psicológicas Completas de Freud; v. XXI)

GAGNEBIN, Jeanne Marie. História e Narração em Walter Benjamin. São Paulo: Perspectiva, 2004.

GENETTE, Gérard. Figures III. Paris: Éditions du Seuil, 1972.

HARKINS, Anthony. Hillbilly: a cultural history of an American icon. New York: Oxford University Press, 2004.

HARVEY, David. A Produção Capitalista do Espaço. 2a ed. São Paulo: Annablume, 2005.

HAUG, Wolfgang F. Crítica da Estética da Mercadoria. Trad. Erlon José Paschoal e Jael Glauce da Fonseca. São Paulo: Fundação Editora da UNESP, 1997.

HAWTHORNE, Nathaniel. The Scarlet Letter. Rutland (USA): Everyman, 1992.

HERRING, George C. America's Longest War: the United States and Vietnam, 1950 - 1975. 3를 ed. New York: McGraw-Hill, 1996.

JAMES, David E. \& BERG, Rick (eds.). The Hidden Foundation: cinema and the question of class. Minneapolis: University of Minnesota Press, 1996.

JAMESON, Fredric. Brecht and Method. London: Verso, 1998. 
JAMESON, Fredric. O Inconsciente Político: a narrativa como ato socialmente simbólico. Trad. Valter Lellis Siqueira. São Paulo: Ática, 1992.

JAMESON, Fredric. As Marcas do Visível. Trad. Marcos Soares et al. Rio de Janeiro: Graal, 1995.

JAPPE, Anselm. Guy Debord: essai. Paris: Éditions Denoël, 2001.

KONDER, Leandro. Walter Benjamin: o marxismo da melancolia. $2^{\underline{a}}$ ed. Rio de Janeiro: Campus, 1989.

KURZ, Robert. O tédio mortal da modernidade. Folha de São Paulo, 28.11.1999, Caderno Mais!, p. 3.

KUTLER, Stanley I. The Wars of Watergate: the last crisis of Richard Nixon. New York: Norton, 1990.

LEITE, Lígia Chiappini M. O Foco Narrativo: ou a polêmica em torno da ilusão. 10ª ed. São Paulo: Ática, 2006.

LELLIS, George. Bertolt Brecht: Cahiers du Cinéma and contemporary film theory. Ann Arbor (USA), UMI Research Press, 1976.

LESSA, Sergio. Lukács - Ética e Política: observações acerca dos fundamentos ontológicos da ética e da política. Chapecó: Argos, 2007.

LESSA, Sergio. Mundo dos Homens: trabalho e ser social. São Paulo: Boitempo Editorial, 2002.

LESSA, Sergio. Para Compreender a Ontologia de Lukács. 3ª ed. ljuí: Ed. Unijuí, 2007. (Coleção Filosofia; 19)

LÖWY, Michael. Walter Benjamin: aviso de incêndio: uma leitura das teses "Sobre o conceito de história". Trad. Wanda Nogueira Caldeira Brant. São Paulo: Boitempo, 2005.

LUKÁCS, Georg. Ensaios Sobre Literatura. Rio de Janeiro: Editora Civilização Brasileira, 1965. 
LUKÁCS, Georg. História e Consciência de Classe: estudos sobre a dialética marxista. Trad. Rodnei Nascimento. São Paulo: Martins Fontes, 2003. (Tópicos)

MALONE, Bill C. Country Music, U. S. A. Austin (USA): University of Texas Press, 1985.

MALONE, Bill C. Don't Get Above Your Raisin': country music and the southern working class. Urbana (USA): University of Illinois Press, 2002.

MARTINS, Luiz Renato. Conflito e Interpretação em Fellini: construção da perspectiva do público. São Paulo: Edusp, 1993.

MARX, Karl. O Capital: crítica da economia política (livro I). 23a ed. Trad. Reginaldo Sant'Anna. Rio de Janeiro: Civilização Brasileira, 2006.

MARX, Karl \& ENGELS, Friedrich. A Ideologia Alemã. Trad. Frank Muller. São Paulo: Martin Claret, 2006.

MARX, Karl \& ENGELS, Friedrich. Manifesto Comunista. Trad. Álvaro Pina. São Paulo: Boitempo Editorial, 1998.

MATUSOW, Allen J. Nixon's Economy: booms, busts, dollars and votes. Lawrence (EUA): University Press of Kansas, 1998.

METZ, Christian. A Significação no Cinema. $2^{\mathrm{a}}$ ed. Trad. Jean-Claude Bernardet. São Paulo: Perspectiva, 2006. (Debates; 54)

MEZAN, Renato. Freud, pensador da cultura. $7^{a}$ ed. São Paulo: Companhia das Letras, 2006.

MILLER, Arthur. On Politics and the Art of Acting. New York: Viking, 2001.

MOREIRA, Eduardo F. P. \& RAGO, Luzia Margareth. O Que é Taylorismo. São Paulo: Brasiliense, 2003.

MUMFORD, Lewis. The City in History: its origins, its transformations, and its prospects. San Diego: Harcourt, 1961. 
NASIO, J. D. Édipo: o complexo do qual nenhuma criança escapa. Trad. André Telles. Rio de Janeiro: Zahar, 2007.

NUNES, Benedito. O Tempo na Narrativa. 2ª ed. São Paulo: Editora Ática, 2003. (Série Fundamentos; v. 31)

OERMANN, Robert K. Grand Ole Opry: the show that made country music famous. Disponível em http://www.opry.com/about/WhatlsTheOpry.html (consultado em 02/04/2012)

PERETTI, Burton W. Jazz in American Culture. Chicago: Ivan R. Dee, 1997.

PETERSON, Richard A. Creating Country Music: fabricating authenticity. Chicago: Univesity of Chicago Press, 1997.

POSTMAN, Neil. Amusing Ourselves to Death: public discourse in the age of show business. New York: Penguin Books, 1985.

PRINCE, Stephen. A New Pot of Gold: Hollywood under the electronic rainbow, 1980 - 1989. Berkeley: University of California Press, 2002. (History of the American Cinema, v. 10)

ROSENFELD, Anatol. Cinema: arte e indústria. São Paulo: Perspectiva, 2002.

ROSENFELD, Anatol. O Teatro Épico. 4를 ed. São Paulo: Perspectiva, 2006.

SARTRE, Jean-Paul. Qu'est-ce que la littérature? Paris: Gallimard, 1948.

SCHWARZ, Roberto. Que Horas São?: ensaios. São Paulo: Companhia das Letras, 1987.

SCHWARZ, Roberto. Sequências Brasileiras. São Paulo: Companhia das Letras, 1999.

SENNETT, Richard. Carne e Pedra: o corpo e a cidade na civilização ocidental. Trad. Marcos Aarão Reis. Rio de Janeiro: BestBolso, 2008.

SILBERMAN, Marc (ed.). Bertolt Brecht on Film and Radio. Trad. Marc Silberman. London: Methuen, 2000. 
SIMMEL, Georg. The Philosophy of Money. Trad. Tom Bottomore \& David Frisby. $2^{\mathrm{a}}$ ed. London: Routledge, 1990.

SINFIELD, Alan. Faultlines: Cultural Materialism and the Politics of Dissident Reading. Berkeley: University of California Press, 1992.

SINGER, Paul. Para Entender o Mundo Financeiro. $2^{2}$ ed. São Paulo: Contexto, 2003.

SOARES, Marcos. O filme de conspiração e a ascensão da nova direita nos Estados Unidos. Revista Lumen et Virtus. v. III, n. 6, jan. 2012. http://www.jackbran.com.br/lumen_et_virtus/numero_6/PDF/O\%20FILME\% 20DE\%20CONSPIRA\%C3\%87\%C3\%83O\%20E\%20A\%20ASCENS\%C3\% 830\%20DA\%20NOVA\%20DIREITA\%20NOS\%20ESTADOS\%20UNIDOS. pdf. Consultado em 9/08/2012.

STEINBECK, John. The Grapes of Wrath. New York: Penguin Books, 1992.

SZONDI, Peter. Teoria do Drama Moderno (1880 - 1950). Trad. Luiz Sérgio Repa. São Paulo: Cosac \& Naify Edições, 2001.

VAZ, Alexandre F. Teoria Crítica do Esporte: desdobramentos, críticas e possível atualidade. Disponível em: http://www.anpocs.org/portal/index.php?option=com_docman\&task=doc_vi ew\&gid=4163\&ltemid=316 (consultado em 20/12/2012)

VONNEGUT, Kurt. Breakfast of Champions. New York: Delacorte Press, 1973.

WEBER, Max. A Ética Protestante e o "Espírito" do Capitalismo. Trad. José Marcos Mariani de Macedo. São Paulo: Companhia das Letras, 2004.

WEIS, Elisabeth \& BELTON, John (ed.). Film Sound: theory and practice. New York: Columbia University Press, 1985.

WILLETT, John (org.). Brecht on Theatre: the development of an aesthetic. Trad. John Willet. New York: Hill and Wang, 1964.

WOLIN, Richard. Walter Benjamin: an aesthetic of redemption. $2^{\underline{a}}$ ed. Berkeley: University of California Press, 1994. 
WYATT, Justin. High Concept: movies and marketing in Hollywood. Austin: University of Texas Press, 1994.

XAVIER, Ismail. O discurso cinematográfico: a opacidade e a transparência. 3ạ ed. São Paulo: Paz e Terra, 2005.

XAVIER, Ismail (org.). A Experiência do Cinema. Rio de Janeiro: Edições Graal, 1983.

XAVIER, Ismail. O Olhar e a Cena: Melodrama, Hollywood, Cinema Novo, Nelson Rodrigues. São Paulo: Cosac Y Naify, 2003. 